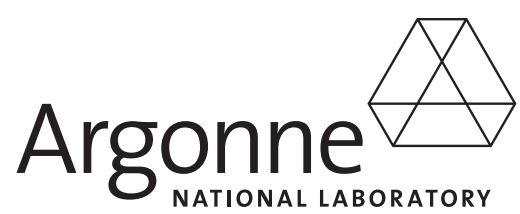

\title{
Semi-Annual Monitoring Report for Barnes, Kansas, for July-December 2009
}

\section{Environmental Science Division}


About Argonne National Laboratory

Argonne is a U.S. Department of Energy laboratory managed by UChicago Argonne, LLC under contract DE-AC02-06CH11357. The Laboratory's main facility is outside Chicago, at 9700 South Cass Avenue, Argonne, Illinois 60439. For information about Argonne and its pioneering science and technology programs, see www.anl.gov.

\section{Availability of This Report}

This report is available, at no cost, at http://www.osti.gov/bridge. It is also available on paper to the U.S. Department of Energy and its contractors, for a processing fee, from:

U.S. Department of Energy

Office of Scientific and Technical Information

P.O. Box 62

Oak Ridge, TN 37831-0062

phone (865) 576-8401

fax (865) 576-5728

reports@adonis.osti.gov

\section{Disclaimer}

This report was prepared as an account of work sponsored by an agency of the United States Government. Reference herein to any specific commercial product, process, or service by trade name, trademark, manufacturer, or otherwise, does not necessarily constitute or imply its endorsement, recommendation, or favoring by the United States Government or any agency thereof. The views and opinions of document authors expressed herein do not necessarily state or reflect those of the United States Government or any agency thereof, Argonne National Laboratory, or UChicago Argonne, LLC. 


\section{Semi-Annual Monitoring Report for Barnes, Kansas, for July-December 2009}

by

Applied Geosciences and Environmental Management Section Environmental Science Division, Argonne National Laboratory

April 2010

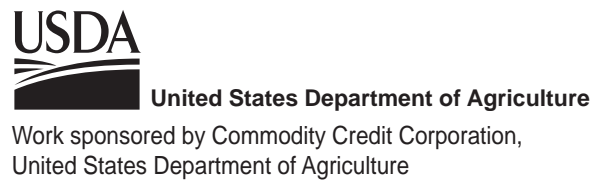




\section{Contents}

Notation.

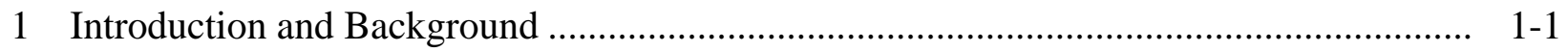

2 Conceptual Site Model.................................................................................. 2-1

3 Sampling and Analysis Activities ................................................................................ 3-1

3.1 Measurement of Groundwater Levels............................................................... 3-1

3.2 Well Sampling and Analyses .................................................................... $3-2$

3.3 Handling and Disposal of Investigation-Derived Waste ...................................... 3-4

3.4 Quality Control for Sample Collection, Handling, and Analysis ............................ 3-4

4 Results and Discussion ......................................................................................

4.1 Groundwater Level Data................................................................................... 4-1

4.2 Analytical Results for Volatile Organic Compounds in Groundwater Samples and Lateral Distribution of the Contaminants.................................................... $4-3$

5 Conclusions and Ongoing Tasks........................................................................... $5-1$

5.1 Conclusions......................................................................................... $5-1$

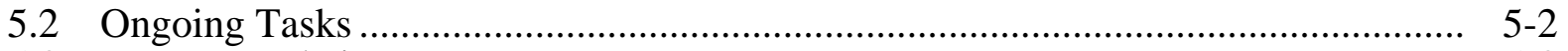

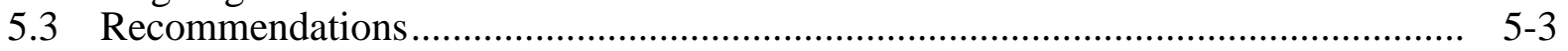

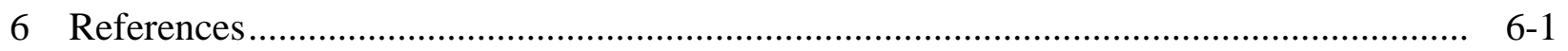

Appendix A: Sampling Activities and Field Measurements at Barnes in SeptemberOctober and December 2009 ................................................................... A-1

Appendix B: $\quad$ Waste Characterization Data.................................................................. B-1

Appendix C: Results from the AGEM Laboratory for Dual Analyses of Samples Collected at Barnes in September-October and December 2009 and for Quality Control Samples

Appendix D: Sample Documentation from TestAmerica Laboratories, Inc.

Appendix E: Trend Analysis of Carbon Tetrachloride Concentration Data for Monitored Wells 


\section{Figures}

1.1 Groundwater sampling locations at Barnes in 2009 ........................................... 1-3

3.1 Wells at Barnes equipped with data loggers for automatic water level monitoring....

4.1a Potentiometric surface map depicting the groundwater flow direction in the deeper aquifer zone at Barnes under static (non-pumping) conditions on October 8, 2009.

4.1b Potentiometric surface map depicting the groundwater flow direction in the deeper aquifer zone at Barnes under pumping conditions on October 9, 2009

4.2a Hydrographs summarizing monthly results of long-term water level monitoring in the deep-zone wells at Barnes, June-December 2009.

4.2b Hydrographs summarizing monthly results of long-term water level monitoring in the intermediate-zone wells at Barnes, June-December 2009

4.3 Analytical results for carbon tetrachloride in groundwater samples collected at Barnes in 2009

4.4 Analytical results for chloroform in groundwater samples collected at Barnes in 2009

4.5 Interpreted carbon tetrachloride plume in September-October 2009 in wells screened in the deep aquifer zone

5.1 Wells proposed for ongoing sampling

\section{Tables}

4.1 Hand-measured water levels at Barnes in 2009.

4.2 Elevation ranges measured for the three aquifer zones, June 2007-October 2009.......

4.3 Analytical results from the AGEM Laboratory for volatile organic compounds in groundwater samples collected at Barnes, July 2006 to December 2009. 


\section{Tables (cont.)}

A.1 Sequence of sampling activities at Barnes in September-October 2009 quarterly monitoring and December 2009 public well sampling.....

A.2 Field measurements for groundwater samples collected at Barnes, July 2006 to December 2009

C.1 Analytical results for samples and replicates collected at Barnes during the September-October 2009 monitoring event and for quality control samples

E.1 Monitoring wells proposed for annual monitoring at Barnes, with carbon tetrachloride concentration trends 


\section{Notation}

AGEM Applied Geosciences and Environmental Management

AMSL above mean sea level

BGL below ground level

${ }^{\circ} \mathrm{C} \quad$ degree(s) Celsius

CCC Commodity Credit Corporation

COC chain of custody

DO dissolved oxygen

EPA U.S. Environmental Protection Agency

$\mathrm{ft} \quad$ foot (feet)

gal gallon(s)

hr hour(s)

in. inch(es)

KDHE Kansas Department of Health and Environment

L liter(s)

$\mu \mathrm{g} / \mathrm{kg} \quad$ microgram(s) per kilogram

$\mu \mathrm{g} / \mathrm{L} \quad$ microgram(s) per liter

$\mu \mathrm{S} / \mathrm{cm} \quad$ microsiemen(s) per centimeter

$\mathrm{mg} / \mathrm{L} \quad$ milligram(s) per liter

min minute

$\mathrm{mV} \quad$ millivolt(s)

ND not detected

ORP oxidation-reduction potential

PWS public water supply

$R^{2} \quad$ statistical value that quantifies goodness of fit of a linear regression

RBSL risk-based screening level

USDA U.S. Department of Agriculture

VOC volatile organic compound 


\section{Semi-Annual Monitoring Report for Barnes, Kansas, for July-December 2009}

\section{Introduction and Background}

The Commodity Credit Corporation of the U.S. Department of Agriculture (CCC/USDA) operated a grain storage facility at Barnes, Kansas, during most of the interval 1949-1974. Carbon tetrachloride contamination was initially detected in 1986 in the town's public water supply wells. In 2006-2007, the CCC/USDA conducted a comprehensive targeted investigation at and near its former property in Barnes to characterize this contamination. Those results were reported previously (Argonne 2008a).

In November 2007, the CCC/USDA began quarterly groundwater monitoring at Barnes. The monitoring is being conducted on behalf of the CCC/USDA by Argonne National Laboratory, in accord with the recommendations made in the report for the 2006-2007 targeted investigation (Argonne 2008a). The objective is to monitor the carbon tetrachloride contamination identified in the groundwater at Barnes. The sampling is presently conducted in a network of 28 individual monitoring wells (at 19 distinct locations), 2 public water supply wells, and 1 private well (Figure 1.1).

The results of the 2006-2007 targeted investigation and the subsequent monitoring events (Argonne 2008a-d, 2009a,b) demonstrated the presence of carbon tetrachloride contamination in groundwater at levels exceeding the Kansas Department of Health and Environment (KDHE) Tier 2 risk-based screening level (RBSL) of $5.0 \mu \mathrm{g} / \mathrm{L}$ for this compound. The contaminant plume appears to extend from the former CCC/USDA property northwestward, toward the Barnes public water supply wells. Information obtained during the 2006-2007 investigation indicates that at least one other potential source might have contributed to the groundwater contaminant plume (Argonne 2008a). The former agriculture building owned by the local school district, located immediately east of well PWS3, is also a potential source of the contamination.

This current report presents the results of the seventh quarterly monitoring event, conducted in September-October, and also sampling of only the public wells in December 2009. During the September-October quarterly event, low-flow sampling methods were used to purge and sample all wells. This was the seventh event at Barnes during which the low-flow sampling method was used. 
After the September-October 2009 quarterly sampling event, the KDHE (2009) approved a change in the sampling frequency for the monitoring wells from quarterly to twice yearly. Quarterly sampling is to continue for the public water supply wells. Accordingly, in December 2009, only the public wells were sampled. All results for the six-month period July-December 2009 are reported here. 


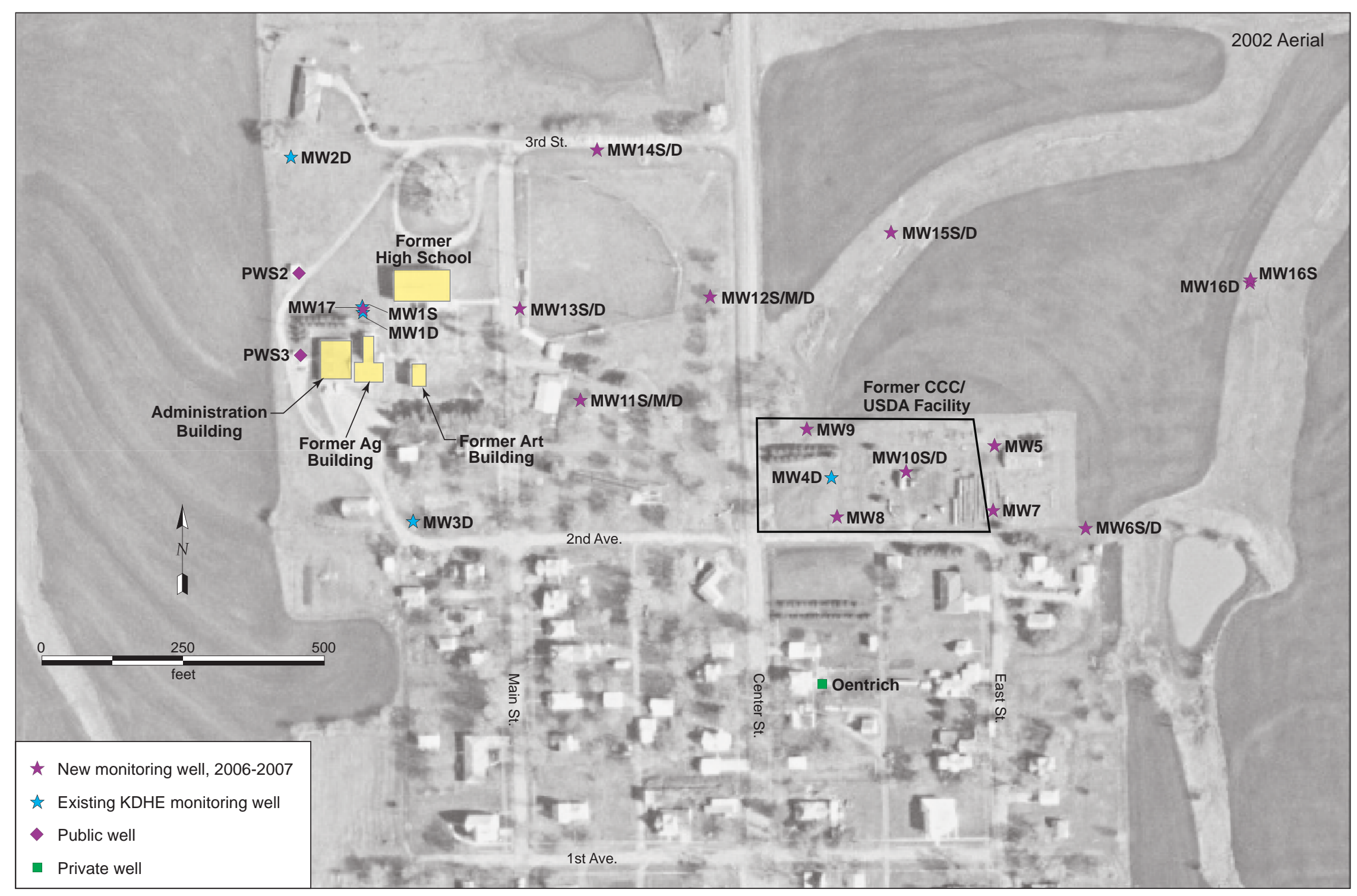

FIGURE 1.1 Groundwater sampling locations at Barnes in 2009. Source of photograph: NAPP (2002). 


\section{Conceptual Site Model}

Barnes lies in a transition zone between the Flint Hills and the glaciated region. The area's topography consists of gently sloping hills of Pleistocene loess (with variations in elevation $<50 \mathrm{ft}$ ) overlying a shale unit and interbedded shale, limestone, and siltstone of the Permian Chase Group. Groundwater for the public water supply is produced from the bedrock aquifer of the Chase Group.

The site lithology and subsurface contaminant conditions were determined in the 20062007 investigation through the collection of continuous core samples at 13 locations (MW5MW17) extending from east of the former CCC/USDA grain storage facility and westward, across the area of concern, toward the public water supply wells (Argonne 20008a). The predominant lithology consists of a thin layer of silty clay to clayey silt with fine sand in the upper 2-20 ft. This layer is underlain by highly weathered shale interbedded with thin layers of fractured limestone at depths of approximately 18-132 ft BGL (below ground level). No soil contamination at concentrations above the RBSL of $200 \mu \mathrm{g} / \mathrm{kg}$ for the soil-to-groundwater protection pathway was detected at any of the 13 locations. Trace concentrations $(<10 \mu \mathrm{gg})$ of carbon tetrachloride were detected in soil at 3 locations on the former CCC/USDA facility property. These low concentrations would not result in higher concentrations in groundwater, and therefore the soil on the former CCC/USDA property is not considered to be a source for the carbon tetrachloride contamination in groundwater.

Groundwater is present predominantly in the fractured limestone layers. Monitoring wells were installed and screened at various depths, with several locations completed as nested wells to determine contaminant concentrations at depths where water-bearing zones were indicated. Throughout the monitoring program, a detailed evaluation of the hand-measured water levels and carbon tetrachloride data has been conducted to investigate the stratigraphy of the saturated zone. The accumulated water level data suggest that at least three vertically distinct aquifer zones are present: shallow, intermediate, and deep. These zones are discussed further in Section 4.1. The vertical distribution of the carbon tetrachloride in groundwater indicates that the highest concentrations (approximately 50-70 $\mu \mathrm{g} / \mathrm{L}$ over the course of the monitoring program to date) occur in the intermediate aquifer zone. Lower concentrations have been detected in the deep aquifer zone, and no carbon tetrachloride has been detected in the shallow zone. Trace levels of carbon tetrachloride have been detected periodically in the two public water supply wells; these wells are believed to be screened over all three aquifer zones. 
Extensive documentation of the potentiometric surface at Barnes during the targeted investigation and subsequent monitoring events (Argonne 2008a-d, 2009a,b) has indicated that operation of the public water supply wells strongly influences the groundwater flow direction. The accumulated data document a predominant direction of groundwater flow to the northeast under non-pumping conditions. In contrast, flow is toward the northwest, in the approximate direction of the public water supply wells, when pumping is occurring. The data demonstrate that the public water supply wells are operated daily, with drawdowns of as much as $2.25 \mathrm{ft}$ during pumping. Pumping and subsequent water level recovery periods typically range from $3 \mathrm{hr}$ to $7 \mathrm{hr}$ in duration, resulting in groundwater levels (and apparent flow directions) that shift relatively continuously throughout much of each day. For this reason, water level data collected by the automatic recorders, which are coincident in time at all monitored locations, provide the primary basis for determination of the topology of the potentiometric surface at any point in the cycles of groundwater pumping and recovery.

The automatic recorder data also provide critical information needed to evaluate the hydrologic regime in anticipation of a corrective action study. The data accumulated prior to November 2008 for recorders installed in deep-zone wells indicated the presence of both vertical and lateral influences on the local hydraulic gradients. In November 2008, intermediate-zone wells were equipped with automatic water level recorders to obtain detailed data on the potential temporal variability of the hydraulic heads in this aquifer zone. 


\section{Sampling and Analysis Activities}

\subsection{Measurement of Groundwater Levels}

The groundwater sampling event at Barnes on September 29-October 1, 2009, involved 28 monitoring wells (MW1S, MW1D, MW2D, MW3D, MW4D, MW5, MW6S, MW6D, MW7, MW8, MW9, MW10S, MW10D, MW11S, MW11M, MW11D, MW12S, MW12M, MW12D, MW13S, MW13D, MW14S, MW14D, MW15S, MW15D, MW16S, MW16D, MW17). All of the well locations are shown in Figure 1.1. A chronological summary of the field activities is in Appendix A, Table A.1.

Before implementation of the low-flow sampling described in Section 3.2, a hand-held water level indicator was used to measure the depth to groundwater and the total depth of each well, to within $0.01 \mathrm{ft}$, from the top of the well casing. During the September-October 2009 event, monitoring wells MW1S and MW12S were measured but were found to be dry and consequently could not be sampled. Two public water supply wells (PWS2 and PWS3) and one private well (Oentrich) were sampled but could not be measured because of the pumps and other equipment in the wells. Introduction of measuring devices could result in damage to the wells.

In addition to the manual water level measurements, since 2006 data recorders have been gathering long-term data on the groundwater elevation and gradient at selected monitoring wells across the investigation area. The data loggers record water levels continuously at 60-min intervals. To augment the data generated by recorders installed in the deeper aquifer zone, in November 2008 water level recorders were installed in five wells - MW10S, MW11M, MW12M, MW13S, and MW17 - to investigate the potential hydraulic influences on groundwater flow and contaminant migration in the intermediate aquifer zone, in which the highest concentrations of carbon tetrachloride in groundwater have been identified. At present, a total of 14 wells are being monitored for water levels, at the locations shown in Figure 3.1.

The hand-measured and automatically recorded groundwater level data are presented and discussed in Section 4.1. 


\subsection{Well Sampling and Analyses}

After measurement of water levels, low-flow groundwater sampling techniques, according to U.S. Environmental Protection Agency (EPA) guidelines (Puls and Barcelona 1996; Yeskis and Zavala 2002), were used to purge and sample the monitoring wells. The Oentrich well and the public water supply wells were sampled at their respective faucets after purging for 5-10 min (Table A.1 in Appendix A). During the September-October 2009 sampling event, public water supply wells PWS2 and PWS3 had been in operation prior to sampling. During the December 2009 sampling, the public well PWS3 was operating, and samples were taken as usual. Well PWS2 was not operating during the December sampling event; however, the well was sampled after purging of approximately 400 gal of water. For public wells PWS2 and PWS3, samples of untreated ("raw") produced water were collected at the wellheads prior to mixing and introduction into the public distribution system.

Under the exact requirements of K.A.R. 28-15, compliance samples would be collected from the distribution system after treatment and after water from the wells had been combined, as indicated in 40 CFR 141.24(f)(3). The sampling of individual wellheads at Barnes to test each well is a more stringent comparison with the Tier 2 standard of $5.0 \mu \mathrm{g} / \mathrm{L}$ than sampling of the blended water.

The low-flow sampling of monitoring wells involved the use of a bladder pump and field measurement equipment designed to determine when representative formation water was entering the well screen (Puls and Barcelona 1996; Yeskis and Zavala 2002). Stabilization of formation water in the screened area of the well was determined by measuring the static water levels and monitoring the levels of $\mathrm{pH}$, temperature, specific conductivity, oxidation-reduction potential (ORP), and dissolved oxygen (DO) during pumping.

The following procedure was followed for each well sampled:

1. A bladder pump was inserted into the well to a depth midway between the top and bottom of the screen. To minimize disturbance of the solids that are typically present at the bottom of a well, care was taken not to lower the pump to the bottom of the casing. 
2. The pumping rate for the bladder pump was set to ensure that minimal drawdown occurred in each well during pumping. The rate was monitored by measuring the static water level periodically throughout pumping.

3. Polyethylene tubing was used to connect the bladder pump to an in-line flow cell. Formation parameters, including $\mathrm{pH}$, temperature, specific conductivity, ORP, and DO, were measured continuously in the in-line flow cell during pumping. Measurements were recorded every 4 min until three successive measurements for each parameter were within a range indicating that the formation water was stable. The range for formation stabilization varies for each parameter, as follows: $\mathrm{pH}$, within 0.1 ; temperature, within $3 \%$; specific conductivity, within 3\%; ORP, within $10 \mathrm{mV}$; and DO, within $10 \%$.

4. After stabilization of the formation water parameters occurred, the polyethylene tubing was disconnected from the in-line flow cell, and a representative groundwater sample was pumped through the tubing into laboratory-approved containers.

5. The polyethylene tubing for each well was kept and dedicated for reuse at that well. In addition, pumping rate data were recorded for each well as a reference for subsequent sampling events.

The sequence of activities during the September-October 2009 quarterly monitoring and the December 2009 public well sampling is summarized in Appendix A, Table A.1. The field measurements are in Appendix A, Table A.2.

Groundwater samples designated for analyses for volatile organic compounds (VOCs) were collected in appropriate laboratory containers, labeled, packaged, and chilled to $4^{\circ} \mathrm{C}$ by placement in ice-filled coolers. The samples were shipped via an overnight delivery service to the Applied Geosciences and Environmental Management (AGEM) Laboratory at Argonne for VOCs analyses with EPA Method 524.2 (EPA 1995). Aliquots of selected samples (chosen in the field) were also shipped to TestAmerica Laboratories, Inc., South Burlington, Vermont, for verification VOCs analyses according to EPA Contract Laboratory Program protocols.

The analytical results are presented and discussed in Section 4.2. 


\subsection{Handling and Disposal of Investigation-Derived Waste}

Purge water generated as potentially contaminated investigation-derived waste was containerized on-site in 55-gal drums. The accumulated purge water (less than two drums) was sampled for VOCs (including ethylene dibromide) and nitrates. The samples were analyzed by a Kansas-certified laboratory, Pace Analytical Services (Lenexa, Kansas). The analytical results are in Appendix B. The concentrations of carbon tetrachloride, chloroform, ethylene dibromide, and nitrate were below the KDHE standards. On November 18, 2009, the wastewater was taken to the Sabetha municipal water treatment facility for disposal.

\subsection{Quality Control for Sample Collection, Handling, and Analysis}

Quality assurance/quality control procedures followed during the monitoring events reported here are described in detail in the Master Work Plan (Argonne 2002). The results are summarized as follows:

- Sample collection and handling activities were monitored by the documentation of samples as they were collected and the use of chain-ofcustody forms and custody seals to ensure sample integrity during handling and shipment.

- Samples designated for VOCs analyses were received with custody seals intact and at the appropriate preservation temperature. All samples sent to the AGEM Laboratory were analyzed within the required holding times.

- Quality control samples collected to monitor sample-handling activities (trip blanks and an equipment rinsate) and method blanks analyzed with the samples to monitor analytical methodologies were all free of carbon tetrachloride and chloroform contamination.

- Groundwater samples were analyzed for VOCs at the AGEM Laboratory by the purge-and-trap method on a gas chromatograph-mass spectrometer system. Calibration checks analyzed with each sample delivery group were required to be within $\pm 20 \%$ of the standard. Surrogate standard determinations 
performed on samples and blanks were within the specified range of $80-120 \%$ for all samples, in either the initial analysis or a successful reanalysis.

- Results from the AGEM Laboratory for dual analyses of the groundwater samples are in Appendix C, Table C.1. The results of the dual analyses compare well, with average relative percent difference values for carbon tetrachloride and chloroform of approximately $4.8 \%$ and $0 \%$, respectively, indicating consistency in the sampling and analytical methodologies. Analytical results for quality control samples are also in Appendix C, Table C.1.

- In accordance with the procedures defined in the Master Work Plan (Argonne 2002), groundwater samples were submitted to a second laboratory (TestAmerica) for verification analysis according to the protocols of the EPA's Contract Laboratory Program. Documentation is in Appendix D. The results from the two laboratories compare favorably, with average relative percent difference values for carbon tetrachloride and chloroform of 15\% and $0 \%$, respectively. Methylene chloride was not detected by either laboratory. The lack of contamination in the sample from public well PWS3 was confirmed in verification analysis. 


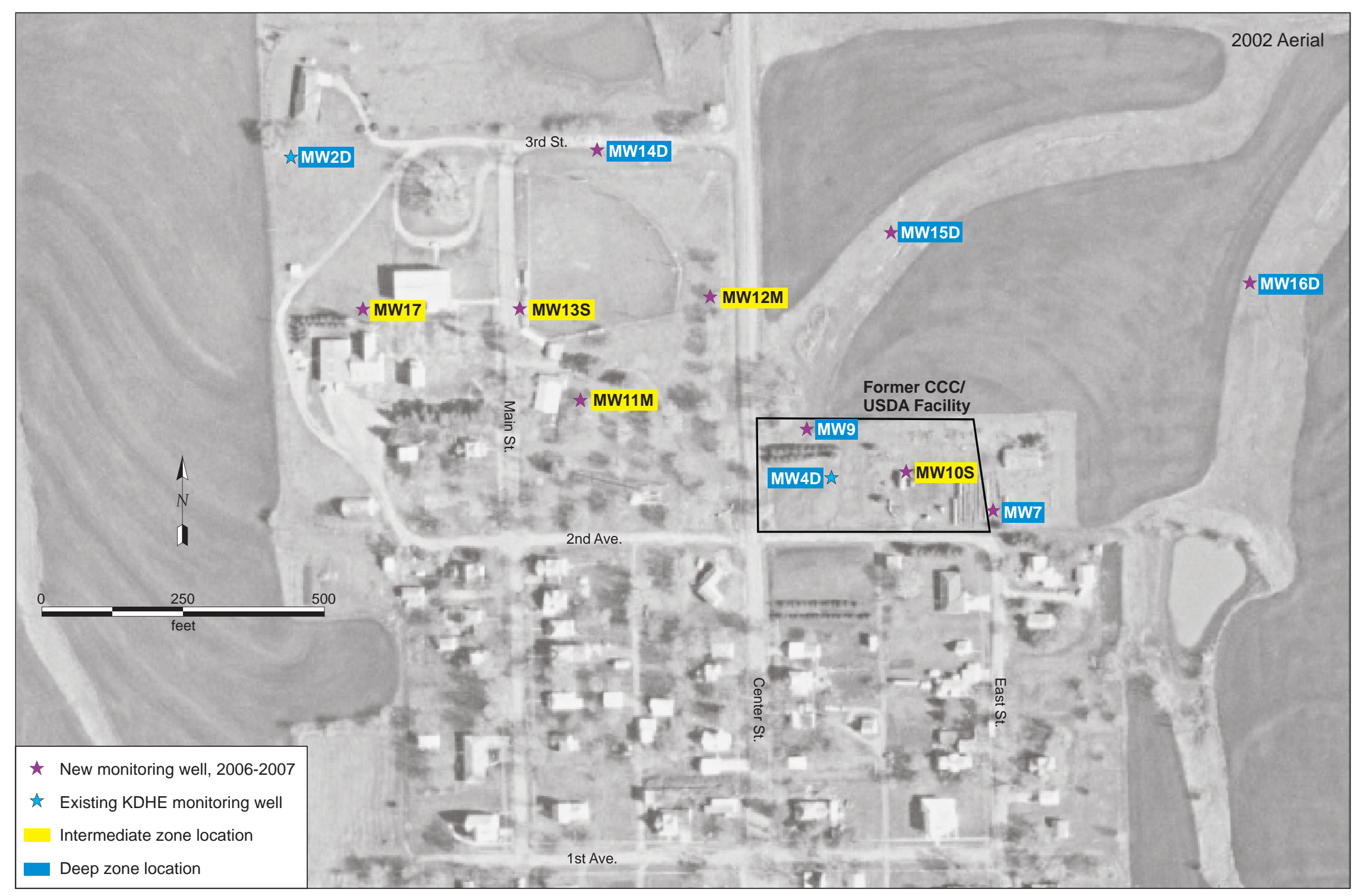

FIGURE 3.1 Wells at Barnes equipped with data loggers for automatic water level monitoring. Source of photograph: NAPP (2002). 


\section{Results and Discussion}

\subsection{Groundwater Level Data}

The manual water level measurements taken during sampling on September 29October 1, 2009, and prior recent monitoring events are in Table 4.1. Evaluation of manual water level measurements (together with the contaminant distribution data discussed in Section 4.2) continues to suggest that three vertically distinguishable aquifer zones are present at Barnes: shallow, intermediate, and deep. The designations "S," "M," and " $\mathrm{D}$ ” in monitoring well names (Table 4.1) were assigned at the time of well installation. They indicate shallow-, medium-, and deep-screened (relative depths) wells in an individual well cluster, rather than the aquifer zone screened. Table 4.2 shows the approximate water level elevations for wells screened in the three aquifer zones, as indicated by the long-term monitoring data accumulated since 2007. Hand measurements taken on October 7, 2009, for all shallow, medium, and deep wells in the monitoring network are included in Table 4.1. As in the prior monitoring events, three vertically distinguished aquifer zones are also evident in the October 2009 event (Table 4.2).

Water level data collected by the automatic recorders, which are coincident in time at all monitored locations, provide the primary basis for determination of the topology of the potentiometric surface at any point in the cycles of groundwater pumping and recovery. Water levels measured by hand over a finite time period in the areally distributed network of monitoring wells at this site cannot generally be relied on to yield a meaningful representation of groundwater flow directions under pumping conditions, because of the documented short-term, transient water level variations that are related to pumping cycles in the public water supply wells. Figure 4.1a presents a potentiometric surface map (under non-pumping conditions) on October 8, 2009, for the network of wells in the deeper aquifer zone currently being monitored (see Section 3.1). Figure 4.1b represents a comparable map derived from measurements taken on October 9, 2009, under pumping conditions.

The hydrographs in Figures 4.2a and 4.2b, respectively, summarize data for the period June 1, 2009, to December 31, 2009, for the recording transducers in the deep-zone wells and the intermediate-zone wells. The hydrographs indicate that since mid-June, water levels across the site have declined slowly. The recorder in deep-zone well MW14D (Figure 4.2a) stopped working on July 31 and was replaced on October 7. The recorder in intermediate-zone well 
MW17 (Figure 4.2b) stopped collecting data on June 17; data collection in this case resumed on October 7 , when the recorder was reprogrammed.

Prior to November 2008, Argonne observed suggestions of the presence of vertical hydraulic gradients in the data from recorders in the deep portion of the aquifer (particularly MW15D). Consequently, in November 2008, wells in the intermediate portion of the aquifer (MW10S, MW11M, MW12M, MW13S, and MW17; Table 4.2) were equipped with automatic water level recorders to generate detailed data on the potential temporal variability of the hydraulic heads in this aquifer zone. The observed groundwater levels in the intermediate zone (Figure 4.2b) do not show the degree of drawdown response observed in the deep wells.

These data, together with the analyses of groundwater samples for VOCs discussed in Section 4.2, support a plausible working interpretation for the movement of groundwater (and carbon tetrachloride) in the study area. The existing results suggest that the entire saturated sequence at Barnes is hydraulically interconnected but varies internally in both vertical and horizontal permeability. The permeability in the more shaly parts of the section (which include the intermediate aquifer zone) appears to be generally lower than the permeability in the deep aquifer zone, and migration pathways might therefore be more complex in the shaly materials. The shaly materials of the intermediate zone appear to have sufficient vertical permeability to have allowed infiltration of carbon tetrachloride into the deeper parts of the section. The vertical permeability is still quite low, however, as evidenced by the significant vertical gradients documented in the nested wells (Table 4.2).

Most of the deep monitoring wells are associated with limestones (see Figures 4.1-4.5 in Argonne 2008a). The logs show that even though MW15D is considered a "deep” well, it is not completed in these limestones. Well MW15D has always returned much higher measured groundwater levels than would be expected, given its relative areal position at the site (Figures 3.1 and 4.2a) and its screened depth. This observation is qualitatively consistent with the hypothesis that the higher groundwater levels in MW15D are a reflection of lower permeability associated with the shales at this location, versus the nearby limestones — which appear to act as better carrier beds.

The observed groundwater levels in the intermediate-zone wells do not appear to define an apparent flow direction toward the public water supply wells, despite the mapped occurrence of the carbon tetrachloride plume in this stratigraphic interval (Section 4.2). The relative water 
levels do, however, appear qualitatively linked to the elevations of the screens in the respective intermediate-zone monitoring wells. Well MW11 has the highest recorded groundwater levels and the shallowest (in terms of elevation) screened interval, with MW10-MW12 the next lower in screened elevations (and water levels), and MW13-MW17 the lowest. The existing data empirically indicate that the measured "head" in each of these wells is more strongly influenced by the vertical position of the well screen than by the areal location of the well in the intermediate zone of the groundwater flow system.

\subsection{Analytical Results for Volatile Organic Compounds in Groundwater Samples and Lateral Distribution of the Contaminants}

The analytical data for VOCs in the groundwater samples collected in SeptemberOctober 2009 and in December 2009 are in Table 4.3, together with data for the previous sampling events at Barnes. The highest concentration of carbon tetrachloride in sitewide monitoring continues to be found at intermediate-zone well MW10S (located in the eastern portion of the former CCC/USDA facility and screened at 93-103 ft BGL), with detections of $49 \mu \mathrm{g} / \mathrm{L}$ in March 2009, $76 \mu \mathrm{g} / \mathrm{L}$ in June 2009, and 53 g/L in September 2009.

Wells MW12M and MW13S are located northwest of well MW10S and in the direction of flow toward the public wells when these wells are in operation. Carbon tetrachloride concentrations at both wells remained fairly stable through 2009, with values at MW12M of 25, 28, and $26 \mu \mathrm{g} / \mathrm{L}$ in March, June, and October, respectively, and values at MW13S of 14, 16, and $12 \mu \mathrm{g} / \mathrm{L}$ in March, June, and September, respectively. The 2009 concentrations trended slightly higher at MW12M and slightly lower at MW13S than values reported in 2007-2008.

The lateral distribution of carbon tetrachloride in groundwater in sampling events in 2009 is illustrated in Figure 4.3. The distribution in September-October 2009 is similar to that during previous events, with slight increases in carbon tetrachloride levels at MW9, MW4D, and MW8 on the former facility and at MW14S to the north. Contaminant concentrations at and near the public water supply wells remained low to undetectable.

Carbon tetrachloride was notably absent in public well PWS2 in September and December 2009, continuing a declining trend from $1.7 \mu \mathrm{g} / \mathrm{L}$ in October 2008 to $<1 \mu \mathrm{g} / \mathrm{L}$ in March 2009 and $1.0 \mu \mathrm{g} / \mathrm{L}$ in June 2009 (Table 4.3 and Figure 4.3). No contamination has been detected in public well PWS3 in the five most recent sampling events, October 2008-December 
2009. Because of the pulsing influence on groundwater flow patterns, depending on whether the public wells are operating, no clear migration trend toward the public wells has been evident in sitewide monitoring to date.

The lateral distribution of chloroform in groundwater in 2009 (Figure 4.4) is also similar to the distribution during previous sampling events. The highest concentration of chloroform in sitewide sampling since 2007 has been found at well MW12M, located northwest of the former CCC/USDA facility and screened at 90-100 ft BGL (in the intermediate aquifer zone), with concentrations of 2.6-5.1 $\mu \mathrm{g} / \mathrm{L}$.

The vertical distribution of carbon tetrachloride in groundwater indicates that the highest concentrations are present in the intermediate zone, at wells MW10S (53 $\mu \mathrm{g} / \mathrm{L}$ ), MW12M (26 $\mu \mathrm{g} / \mathrm{L})$, and MW13S (12 $\mu \mathrm{g} / \mathrm{L})$. The deep-zone wells at these locations showed little to no change in carbon tetrachloride concentrations between 2009 sampling events. Results for well MW10D were $5.3 \mu / \mathrm{L}$ in March, $4.8 \mu / \mathrm{L}$ in June, and $4.3 \mu / \mathrm{L}$ in September. Well MW12D contained a trace amount (estimated at $0.7 \mu \mathrm{g} / \mathrm{L}$ ) in March, no detectable amount in June, and a concentration of $1.5 \mu \mathrm{g} / \mathrm{L}$ in October. Results for well MW13D trended very slightly higher, with values of $5.9 \mu / \mathrm{L}$ in March, $6.2 \mu \mathrm{g} / \mathrm{L}$ in June, and $7.2 \mu \mathrm{g} / \mathrm{L}$ in September. Figure 4.5 illustrates the interpreted contaminant distributions in the deep zone in September-October 2009.

Shallow-zone well MW11S continued to show no detectable concentrations of carbon tetrachloride. Shallow-zone well MW12S was dry and not sampled (Table 4.3 and Figure 4.3).

In keeping with the groundwater level relationships outlined in Section 4.1, the above observations suggest that groundwater and carbon tetrachloride might be relatively less mobile in the (shaly) intermediate-zone lithologies than in the deeper limestones. Both vertical and horizontal hydraulic gradients are expected to drive contaminant migration in the shaly materials, while horizontal groundwater flow (and contaminant migration) might predominate in the deeper limestones. Because of the inferred higher permeability in the deeper limestones, the carbon tetrachloride in this zone might be more effectively mixed and diluted by groundwater movement in response to the oscillatory hydraulic gradients imparted by pumping of the public wells, while the movement of groundwater and hence carbon tetrachloride in the intermediatezone lithologies is more restricted. 
TABLE 4.1 Hand-measured water levels at Barnes in 2009.

\begin{tabular}{|c|c|c|c|c|c|c|c|c|c|}
\hline \multirow[b]{3}{*}{ Well } & \multirow{3}{*}{$\begin{array}{l}\text { Reference } \\
\text { Elevation } \\
\text { (ft AMSL) }\end{array}$} & \multicolumn{8}{|c|}{ Water Level on Date Indicated } \\
\hline & & \multicolumn{2}{|c|}{$2 / 11 / 09$} & \multicolumn{2}{|c|}{$3 / 4-5 / 09$} & \multicolumn{2}{|c|}{$5 / 21 / 09$} & \multicolumn{2}{|c|}{$10 / 7 / 09$} \\
\hline & & $\mathrm{ft}$ TOC $^{\mathrm{a}}$ & ft AMSL & $\mathrm{ft} \mathrm{TOC}$ & ft AMSL & $\mathrm{ft}$ TOC $^{\mathrm{a}}$ & ft AMSL & $\mathrm{ft}$ TOC $^{\mathrm{a}}$ & ft AMSL \\
\hline \multicolumn{10}{|c|}{ Shallow aquifer zone } \\
\hline MW1S & 1351.58 & $N M^{b}$ & - & - & - & - & - & - & - \\
\hline MW11S & 1336.58 & NM & - & 28.00 & 1308.58 & - & - & 29.80 & 1306.78 \\
\hline MW12S & 1327.46 & NM & - & - & - & - & - & 52.15 & 1275.31 \\
\hline \multicolumn{10}{|c|}{ Intermediate aquifier zone } \\
\hline MW10S & 1331.33 & 75.13 & 1256.20 & 76.00 & 1255.33 & 74.56 & 1256.77 & 75.64 & 1255.69 \\
\hline MW11M & 1336.51 & 79.87 & 1256.64 & 80.30 & 1256.21 & 79.42 & 1257.09 & 80.11 & 1256.40 \\
\hline MW12M & 1327.46 & 71.46 & 1256.00 & 76.50 & 1250.96 & 70.97 & 1256.49 & 71.78 & 1255.68 \\
\hline MW13S & 1342.36 & 87.98 & 1254.38 & 88.75 & 1253.61 & 87.11 & 1255.25 & 88.39 & 1253.97 \\
\hline MW17 & 1351.77 & 97.48 & 1254.29 & 98.10 & 1253.67 & 96.71 & 1255.06 & 97.76 & 1254.01 \\
\hline \multicolumn{10}{|c|}{ Deep aquifer zone } \\
\hline MW1D & 1351.33 & 118.55 & 1232.78 & 119.90 & 1231.43 & 116.82 & 1234.51 & 119.74 & 1231.59 \\
\hline MW2D & 1348.85 & 116.34 & 1232.51 & 117.10 & 1231.75 & 114.59 & 1234.26 & 117.50 & 1231.35 \\
\hline MW3D & 1345.99 & 113.05 & 1232.94 & 116.10 & 1229.89 & 111.28 & 1234.71 & 114.26 & 1231.73 \\
\hline MW4D & 1326.32 & 94.34 & 1231.98 & 94.75 & 1231.57 & - & - & 95.66 & 1230.66 \\
\hline MW5 & 1327.20 & NM & - & 96.90 & 1230.30 & - & - & - & - \\
\hline MW6S & 1323.13 & NM & - & 87.00 & 1236.13 & - & - & 88.84 & 1234.29 \\
\hline MW6D & 1323.15 & NM & - & 93.00 & 1230.15 & - & - & 93.07 & 1230.08 \\
\hline MW7 & 1329.91 & 98.19 & 1231.72 & 99.80 & 1230.11 & 96.50 & 1233.41 & 99.50 & 1230.41 \\
\hline MW8 & 1330.06 & NM & - & 98.60 & 1231.46 & - & - & 99.39 & 1230.67 \\
\hline MW9 & 1321.86 & 89.91 & 1231.95 & 90.40 & 1231.46 & 88.16 & 1233.70 & 91.26 & 1230.60 \\
\hline MW10D & 1331.33 & 113.69 & 1217.64 & 101.30 & 1230.03 & - & - & 100.77 & 1230.56 \\
\hline MW11D & 1336.53 & NM & - & 105.03 & 1231.50 & - & - & 105.08 & 1231.45 \\
\hline MW12D & 1327.52 & NM & - & 96.80 & 1230.72 & - & - & 96.90 & 1230.62 \\
\hline MW13D & 1342.37 & NM & - & 110.58 & 1231.79 & - & - & 111.01 & 1231.36 \\
\hline MW14S & 1332.69 & NM & - & 101.30 & 1231.39 & - & - & 101.74 & 1230.95 \\
\hline MW14D & 1332.74 & 100.57 & 1232.17 & 103.20 & 1229.54 & 98.89 & 1233.85 & 101.76 & 1230.98 \\
\hline MW15S & 1309.34 & NM & - & 78.80 & 1230.54 & - & - & 79.39 & 1229.95 \\
\hline MW15D & 1309.29 & 72.49 & 1236.80 & 73.60 & 1235.69 & 68.31 & 1240.98 & 72.26 & 1237.03 \\
\hline MW16S & 1299.47 & NM & - & 69.60 & 1229.87 & - & - & 70.51 & 1228.96 \\
\hline MW16D & 1299.52 & 68.56 & 1230.96 & 69.00 & 1230.52 & 67.09 & 1232.43 & 70.30 & 1229.22 \\
\hline Oentrich ${ }^{C}$ & 1336.93 & NM & - & NM & - & NM & - & - & - \\
\hline
\end{tabular}

a TOC, top of casing.

b NM, not measured.

c The Oentrich well water level was measured from the concrete at the top of the well vault. The value shown was corrected by $5.5 \mathrm{ft}$ to give a measured depth from the top of the casing. 
TABLE 4.2 Elevation ranges measured for the three aquifer zones, June 2007-October 2009.

\begin{tabular}{lccc}
\hline & \multicolumn{3}{c}{ Elevation of Aquifer Zone (ft AMSL) } \\
\cline { 2 - 4 } Date & Shallow & Intermediate & Deep \\
\hline October 2009 & $1,275-1,307$ & $1,254-1,256$ & $1,229-1,237$ \\
June 2009 & $1,274-1,310$ & $1,255-1,258$ & $1,232-1,241$ \\
March 2009 & 1,308 & $1,251-1,256$ & $1,229-1,236$ \\
November 2008 & - & $1,257-1,259$ & $1,233-1,242$ \\
October 2008 & 1,314 & $1,256-1,259$ & $1,235-1,242$ \\
July 2008 & 1,312 & $1,255-1,258$ & $1,229-1,239$ \\
March 2008 & 1,309 & $1,250-1,254$ & $1,223-1,229$ \\
November 2007 & 1,307 & $1,249-1,254$ & $1,220-1,239$ \\
June 2007 & $1,276-1,314$ & $1,247-1,254$ & $1,221-1,228$ \\
\hline
\end{tabular}


TABLE 4.3 Analytical results from the AGEM Laboratory for volatile organic compounds in groundwater samples collected at Barnes, July 2006 to December 2009.

\begin{tabular}{|c|c|c|c|c|c|c|}
\hline \multirow[b]{2}{*}{ Location } & \multirow[b]{2}{*}{$\begin{array}{l}\text { Depth } \\
\text { (ft BGL) }\end{array}$} & \multirow[b]{2}{*}{ Sample } & \multirow[b]{2}{*}{$\begin{array}{l}\text { Sampling } \\
\text { Date }\end{array}$} & \multicolumn{3}{|c|}{ Concentration $(\mu \mathrm{g} / \mathrm{L})$} \\
\hline & & & & $\begin{array}{c}\text { Carbon } \\
\text { Tetrachloride }\end{array}$ & Chloroform & $\begin{array}{l}\text { Methyle } \\
\text { Chlori }\end{array}$ \\
\hline \multicolumn{7}{|c|}{ Previously existing monitoring wells } \\
\hline \multirow[t]{9}{*}{ MW1S } & $13.3-23.3$ & Not sampled (well dry) & $7 / 19 / 06$ & - & - & - \\
\hline & & Not sampled (well dry) & $4 / 4 / 07$ & - & - & - \\
\hline & & Not sampled (well dry) & $11 / 18 / 07$ & - & - & - \\
\hline & & Not sampled (well dry) & $3 / 4 / 08$ & - & - & - \\
\hline & & Not sampled (well dry) & $7 / 9 / 08$ & - & - & - \\
\hline & & Not sampled (well dry) & $10 / 22 / 08$ & - & - & - \\
\hline & & Not sampled (well dry) & $3 / 4 / 09$ & - & - & - \\
\hline & & Not sampled (well dry) & $6 / 17 / 09$ & - & - & - \\
\hline & & Not sampled (well dry) & 9/30/09 & - & - & - \\
\hline \multirow[t]{9}{*}{ MW1D } & $139.85-159.4$ & BAMW1D-W-21688 & $7 / 19 / 06$ & 1.0 & $N D^{a}$ & ND \\
\hline & & BAMW1D-W-22565 & $4 / 4 / 07$ & 1.2 & ND & ND \\
\hline & & BAMW1D-W-22593 & $11 / 18 / 07$ & ND & ND & ND \\
\hline & & BAMW1D-W-22627 & $3 / 4 / 08$ & $0.2 \mathrm{~J}^{\mathrm{b}}$ & ND & ND \\
\hline & & BAMW1D-W-22668 & 7/9/08 & $0.2 \mathrm{~J}$ & ND & ND \\
\hline & & BAMW1D-W-27720 & $10 / 22 / 08$ & ND & ND & ND \\
\hline & & BAMW1D-W-22703 & $3 / 4 / 09$ & ND & ND & ND \\
\hline & & BAMW1D-W-28639 & $6 / 17 / 09$ & ND & ND & ND \\
\hline & & BAMW1D-W-28678 & 9/30/09 & $0.3 \mathrm{~J}$ & ND & ND \\
\hline \multirow[t]{9}{*}{ MW2D } & $133.26-152.93$ & BAMW2D-W-21687 & $7 / 19 / 06$ & ND & ND & ND \\
\hline & & BAMW2D-W-22564 & $4 / 4 / 07$ & ND & ND & ND \\
\hline & & BAMW2D-W-22594 & $11 / 18 / 07$ & ND & ND & ND \\
\hline & & BAMW2D-W-22628 & $3 / 7 / 08$ & ND & ND & ND \\
\hline & & BAMW2D-W-22669 & $7 / 10 / 08$ & ND & ND & ND \\
\hline & & BAMW2D-W-27721 & $10 / 22 / 08$ & ND & ND & ND \\
\hline & & BAMW2D-W-22704 & $3 / 4 / 09$ & ND & ND & ND \\
\hline & & BAMW2D-W-28640 & $6 / 18 / 09$ & ND & ND & ND \\
\hline & & BAMW2D-W-28679 & 9/30/09 & ND & ND & ND \\
\hline \multirow[t]{9}{*}{ MW3D } & $133.02-152.73$ & BAMW3D-W-21686 & $7 / 19 / 06$ & ND & ND & ND \\
\hline & & BAMW3D-W-22567 & $4 / 4 / 07$ & ND & ND & ND \\
\hline & & BAMW3D-W-22595 & $11 / 19 / 07$ & ND & ND & ND \\
\hline & & BAMW3D-W-22629 & $3 / 7 / 08$ & ND & ND & ND \\
\hline & & BAMW3D-W-22670 & $7 / 10 / 08$ & ND & ND & ND \\
\hline & & BAMW3D-W-27722 & $10 / 22 / 08$ & ND & ND & ND \\
\hline & & BAMW3D-W-22705 & $3 / 4 / 09$ & ND & ND & ND \\
\hline & & BAMW3D-W-28641 & $6 / 17 / 09$ & ND & ND & ND \\
\hline & & BAMW3D-W-28680 & 9/30/09 & ND & ND & ND \\
\hline \multirow[t]{9}{*}{ MW4D } & $98.38-118.22$ & BAMW4D-W-21690 & $7 / 20 / 06$ & 2.1 & ND & ND \\
\hline & & BAMW4D-W-22583 & $4 / 6 / 07$ & 3.5 & $0.1 \mathrm{~J}$ & ND \\
\hline & & BAMW4D-W-22596 & $11 / 19 / 07$ & 1.7 & $0.4 \mathrm{~J}$ & ND \\
\hline & & BAMW4D-W-22642 & 3/9/08 & 18 & $0.4 \mathrm{~J}$ & ND \\
\hline & & BAMW4D-W-22671 & $7 / 12 / 08$ & 9.4 & $0.5 \mathrm{~J}$ & ND \\
\hline & & BAMW4D-W-27723 & $10 / 23 / 08$ & 7.6 & ND & ND \\
\hline & & BAMW4D-W-22706 & $3 / 5 / 09$ & 7.2 & $0.3 \mathrm{~J}$ & ND \\
\hline & & BAMW4D-W-28642 & 6/18/09 & 9.1 & ND & ND \\
\hline & & BAMW4D-W-28681 & 9/30/09 & 13 & $0.3 \mathrm{~J}$ & ND \\
\hline
\end{tabular}


TABLE 4.3 (Cont.)

\begin{tabular}{|c|c|c|c|c|c|c|}
\hline \multirow[b]{2}{*}{ Location } & \multirow[b]{2}{*}{$\begin{array}{l}\text { Depth } \\
\text { (ft BGL) }\end{array}$} & \multirow[b]{2}{*}{ Sample } & \multirow[b]{2}{*}{$\begin{array}{l}\text { Sampling } \\
\text { Date }\end{array}$} & \multicolumn{3}{|c|}{ Concentration $(\mu \mathrm{g} / \mathrm{L})$} \\
\hline & & & & $\begin{array}{c}\text { Carbon } \\
\text { Tetrachloride }\end{array}$ & Chloroform & $\begin{array}{c}\text { Methylene } \\
\text { Chloride }\end{array}$ \\
\hline \multicolumn{7}{|c|}{ CCC/USDA wells installed during the 2006-2007 investigation } \\
\hline \multirow[t]{8}{*}{ MW5 } & $110-120$ & BAMW5-W-22589 & $4 / 6 / 07$ & $0.6 \mathrm{~J}$ & ND & ND \\
\hline & & BAMW5-W-22597 & $11 / 19 / 07$ & $0.6 \mathrm{~J}$ & ND & ND \\
\hline & & BAMW5-W-22637 & $3 / 8 / 08$ & $0.7 \mathrm{~J}$ & ND & ND \\
\hline & & BAMW5-W-22672 & $7 / 11 / 08$ & ND & ND & ND \\
\hline & & BAMW5-W-27724 & $10 / 23 / 08$ & 3.0 & ND & ND \\
\hline & & BAMW5-W-22707 & $3 / 5 / 09$ & 3.2 & ND & ND \\
\hline & & BAMW5-W-28643 & 6/19/09 & 4.8 & ND & ND \\
\hline & & BAMW5-W-28682 & 9/30/09 & 7.2 & ND & ND \\
\hline \multirow{8}{*}{ MW6S } & $90.5-100.5$ & Not sampled (well dry) & $4 / 4 / 07$ & - & - & - \\
\hline & & BAMW6S-W-22598 & $11 / 19 / 07$ & $0.3 \mathrm{~J}$ & ND & ND \\
\hline & & BAMW6S-W-22635 & $3 / 8 / 08$ & $0.4 \mathrm{~J}$ & ND & ND \\
\hline & & BAMW6S-W-22673 & $7 / 11 / 08$ & ND & ND & ND \\
\hline & & BAMW6S-W-27725 & $10 / 23 / 08$ & ND & ND & ND \\
\hline & & BAMW6S-W-22708 & $3 / 5 / 09$ & ND & ND & ND \\
\hline & & BAMW6S-W-28644 & 6/18/09 & ND & ND & ND \\
\hline & & BAMW6S-W-28683 & $10 / 1 / 09$ & ND & ND & ND \\
\hline \multirow[t]{8}{*}{ MW6D } & $105-115$ & BAMW6D-W-22573 & $4 / 5 / 07$ & ND & ND & ND \\
\hline & & BAMW6D-W-22599 & $11 / 19 / 07$ & $0.5 \mathrm{~J}$ & ND & ND \\
\hline & & BAMW6D-W-22636 & $3 / 8 / 08$ & $0.8 \mathrm{~J}$ & ND & ND \\
\hline & & BAMW6D-W-22674 & $7 / 11 / 08$ & $0.9 \mathrm{~J}$ & ND & ND \\
\hline & & BAMW6D-W-27726 & $10 / 23 / 08$ & 1.1 & ND & ND \\
\hline & & BAMW6D-W-22709 & $3 / 5 / 09$ & 1.4 & ND & ND \\
\hline & & BAMW6D-W-28645 & $6 / 18 / 09$ & 1.5 & ND & ND \\
\hline & & BAMW6D-W-28684 & $10 / 1 / 09$ & 1.5 & ND & ND \\
\hline \multirow[t]{8}{*}{ MW7 } & $116-126$ & BAMW7-W-22588 & $4 / 6 / 07$ & 1.0 & ND & ND \\
\hline & & BAMW7-W-22600 & $11 / 19 / 07$ & 2.6 & ND & ND \\
\hline & & BAMW7-W-22643 & $3 / 9 / 08$ & 2.8 & ND & ND \\
\hline & & BAMW7-W-22675 & $7 / 12 / 08$ & 1.7 & ND & ND \\
\hline & & BAMW7-W-27727 & $10 / 23 / 08$ & 2.1 & ND & ND \\
\hline & & BAMW7-W-22710 & $3 / 5 / 09$ & 1.4 & ND & ND \\
\hline & & BAMW7-W-28646 & 6/19/09 & 1.4 & ND & ND \\
\hline & & BAMW7-W-28685 & 9/30/09 & 1.6 & ND & ND \\
\hline \multirow{8}{*}{ MW8 } & $110-120$ & BAMW8-W-22584 & $4 / 6 / 07$ & 14 & $0.7 \mathrm{~J}$ & ND \\
\hline & & BAMW8-W-22601 & $11 / 19 / 07$ & 23 & $0.6 \mathrm{~J}$ & ND \\
\hline & & BAMW8-W-22652 & $3 / 10 / 08$ & 19 & $0.6 \mathrm{~J}$ & ND \\
\hline & & BAMW8-W-22676 & $7 / 11 / 08$ & 21 & $0.6 \mathrm{~J}$ & ND \\
\hline & & BAMW8-W-27728 & $10 / 23 / 08$ & 24 & 1.0 & ND \\
\hline & & BAMW8-W-22711 & $3 / 5 / 09$ & 20 & 1.3 & ND \\
\hline & & BAMW8-W-28647 & $6 / 19 / 09$ & 26 & 1.7 & ND \\
\hline & & BAMW8-W-28686 & 9/30/09 & 29 & 2.2 & ND \\
\hline \multirow[t]{6}{*}{ MW9 } & $100-110$ & BAMW9-W-22582 & $4 / 5 / 07$ & 1.0 & ND & ND \\
\hline & & BAMW9-W-22602 & $11 / 19 / 07$ & 7.7 & $0.6 \mathrm{~J}$ & ND \\
\hline & & BAMW9-W-22647 & $3 / 9 / 08$ & 3.0 & $0.3 \mathrm{~J}$ & ND \\
\hline & & BAMW9-W-22678 & $7 / 11 / 08$ & 1.3 & $0.3 \mathrm{~J}$ & ND \\
\hline & & BAMW9-W-27729 & $10 / 24 / 08$ & 2.2 & $0.2 \mathrm{~J}$ & ND \\
\hline & & BAMW9-W-22712 & $3 / 5 / 09$ & 2.3 & ND & ND \\
\hline
\end{tabular}


TABLE 4.3 (Cont.)

\begin{tabular}{|c|c|c|c|c|c|c|}
\hline \multirow[b]{2}{*}{ Location } & \multirow[b]{2}{*}{$\begin{array}{c}\text { Depth } \\
\text { (ft BGL) }\end{array}$} & \multirow[b]{2}{*}{ Sample } & \multirow[b]{2}{*}{$\begin{array}{l}\text { Sampling } \\
\text { Date }\end{array}$} & \multicolumn{3}{|c|}{ Concentration $(\mu \mathrm{g} / \mathrm{L})$} \\
\hline & & & & $\begin{array}{c}\text { Carbon } \\
\text { Tetrachloride }\end{array}$ & Chloroform & $\begin{array}{l}\text { Methyle } \\
\text { Chlori }\end{array}$ \\
\hline \multicolumn{7}{|c|}{ CCC/USDA wells installed during the $2006-2007$ investigation (cont.) } \\
\hline \multirow[t]{2}{*}{ MW9 } & $100-110$ & BAMW9-W-28648 & $6 / 17 / 09$ & 1.1 & ND & ND \\
\hline & & BAMW9-W-28687 & $9 / 29 / 09$ & 4.6 & ND & ND \\
\hline \multirow[t]{8}{*}{ MW10S } & 93-103 & BAMW10S-W-22586 & $4 / 6 / 07$ & 20 & 1.4 & ND \\
\hline & & BAMW10S-W-22603 & $11 / 19 / 07$ & 11 & $0.7 \mathrm{~J}$ & ND \\
\hline & & BAMW10S-W-22649 & 3/10/08 & 56 & 2.0 & ND \\
\hline & & BAMW10S-W-22679 & 7/11/08 & 49 & 1.8 & ND \\
\hline & & BAMW10S-W-27730 & $10 / 23 / 08$ & 68 & 2.3 & ND \\
\hline & & BAMW10S-W-22713 & $3 / 5 / 09$ & 49 & 2.1 & ND \\
\hline & & BAMW10S-W-28649 & $6 / 19 / 09$ & 76 & 2.5 & ND \\
\hline & & BAMW10S-W-28688 & $9 / 30 / 09$ & 53 & 2.4 & ND \\
\hline \multirow{8}{*}{ MW10D } & $115-125$ & BAMW10D-W-22585 & $4 / 6 / 07$ & 2.4 & $0.2 \mathrm{~J}$ & ND \\
\hline & & BAMW10D-W-22604 & $11 / 19 / 07$ & 6.3 & $0.5 \mathrm{~J}$ & ND \\
\hline & & BAMW10D-W-22646 & $3 / 9 / 08$ & 5.7 & $0.5 \mathrm{~J}$ & ND \\
\hline & & BAMW10D-W-22680 & 7/11/08 & 3.9 & $0.7 \mathrm{~J}$ & ND \\
\hline & & BAMW10D-W-27731 & $10 / 23 / 08$ & 4.4 & $0.6 \mathrm{~J}$ & ND \\
\hline & & BAMW10D-W-22714 & $3 / 5 / 09$ & 5.3 & $0.4 \mathrm{~J}$ & ND \\
\hline & & BAMW10D-W-28650 & $6 / 19 / 09$ & 4.8 & $0.6 \mathrm{~J}$ & ND \\
\hline & & BAMW10D-W-28689 & $9 / 30 / 09$ & 4.3 & $0.4 \mathrm{~J}$ & ND \\
\hline \multirow{8}{*}{ MW11S } & $40-50$ & BAMW11S-W-22570 & $4 / 4 / 07$ & ND & 1.1 & ND \\
\hline & & BAMW11S-W-22605 & $11 / 19 / 07$ & ND & $0.6 \mathrm{~J}$ & ND \\
\hline & & BAMW11S-W-22630 & $3 / 5 / 08$ & ND & $0.6 \mathrm{~J}$ & ND \\
\hline & & BAMW11S-W-22681 & 7/10/08 & ND & $0.4 \mathrm{~J}$ & ND \\
\hline & & BAMW11S-W-27732 & $10 / 23 / 08$ & ND & $0.3 \mathrm{~J}$ & ND \\
\hline & & BAMW11S-W-22715 & $3 / 4 / 09$ & ND & ND & ND \\
\hline & & BAMW11S-W-28651 & $6 / 19 / 09$ & ND & ND & ND \\
\hline & & BAMW11S-W-28690 & 10/1/09 & ND & ND & ND \\
\hline \multirow{8}{*}{ MW11M } & $90-100$ & BAMW11M-W-22572 & $4 / 5 / 07$ & ND & ND & ND \\
\hline & & BAMW11M-W-22606 & $11 / 19 / 07$ & 3.7 & ND & ND \\
\hline & & BAMW11M-W-22644 & $3 / 6 / 08$ & 2.4 & $0.5 \mathrm{~J}$ & ND \\
\hline & & BAMW11M-W-22682 & 7/10/08 & 2.4 & $0.7 \mathrm{~J}$ & ND \\
\hline & & BAMW11M-W-27733 & 10/23/08 & 1.7 & 2.1 & ND \\
\hline & & BAMW11M-W-22716 & $3 / 4 / 09$ & $0.6 \mathrm{~J}$ & 1.2 & ND \\
\hline & & BAMW11M-W-28652 & $6 / 19 / 09$ & ND & 1.1 & ND \\
\hline & & BAMW11M-W-28691 & 10/1/09 & ND & $0.5 \mathrm{~J}$ & ND \\
\hline \multirow[t]{8}{*}{ MW11D } & $125-135$ & BAMW11D-W-22571 & $4 / 4 / 07$ & 1.1 & ND & ND \\
\hline & & BAMW11D-W-22607 & $11 / 19 / 07$ & $0.8 \mathrm{~J}$ & ND & ND \\
\hline & & BAMW11D-W-22639 & $3 / 5 / 08$ & $0.4 \mathrm{~J}$ & ND & ND \\
\hline & & BAMW11D-W-22683 & 7/10/08 & $0.9 \mathrm{~J}$ & ND & ND \\
\hline & & BAMW11D-W-27734 & $10 / 23 / 08$ & $0.9 \mathrm{~J}$ & $0.2 \mathrm{~J}$ & ND \\
\hline & & BAMW11D-W-22717 & $3 / 4 / 09$ & $0.8 \mathrm{~J}$ & ND & ND \\
\hline & & BAMW11D-W-28653 & $6 / 19 / 09$ & ND & ND & ND \\
\hline & & BAMW11D-W-28692 & 10/1/09 & 1.0 & ND & ND \\
\hline \multirow[t]{3}{*}{ MW12S } & $43-50$ & Not sampled (well dry) & $4 / 5 / 07$ & - & - & - \\
\hline & & Not sampled (well dry) & $11 / 19 / 07$ & - & - & - \\
\hline & & Not sampled (well dry) & $3 / 10 / 08$ & - & - & - \\
\hline
\end{tabular}


TABLE 4.3 (Cont.)

\begin{tabular}{|c|c|c|c|c|c|c|}
\hline \multirow[b]{2}{*}{ Location } & \multirow[b]{2}{*}{$\begin{array}{c}\text { Depth } \\
\text { (ft BGL) }\end{array}$} & \multirow[b]{2}{*}{ Sample } & \multirow[b]{2}{*}{$\begin{array}{l}\text { Sampling } \\
\text { Date }\end{array}$} & \multicolumn{3}{|c|}{ Concentration $(\mu \mathrm{g} / \mathrm{L})$} \\
\hline & & & & $\begin{array}{l}\text { Carbon } \\
\text { Tetrachloride }\end{array}$ & Chloroform & $\begin{array}{l}\text { Methyl } \\
\text { Chlori }\end{array}$ \\
\hline \multicolumn{7}{|c|}{ CCC/USDA wells installed during the 2006-2007 investigation (cont.) } \\
\hline \multirow[t]{5}{*}{ MW12S } & $43-50$ & Not sampled (well dry) & $7 / 10 / 08$ & - & - & - \\
\hline & & Not sampled (well dry) & $10 / 22 / 08$ & - & - & - \\
\hline & & Not sampled (well dry) & $3 / 4 / 09$ & - & - & - \\
\hline & & BAMW12S-W-28654 & $6 / 19 / 09$ & ND & ND & ND \\
\hline & & Not sampled (well dry) & $10 / 1 / 09$ & - & - & - \\
\hline \multirow[t]{8}{*}{ MW12M } & $90-100$ & BAMW12M-W-22580 & $4 / 5 / 07$ & 20 & 4.2 & ND \\
\hline & & BAMW12M-W-22609 & $11 / 19 / 07$ & 18 & 5.1 & ND \\
\hline & & BAMW12M-W-22651 & 3/10/08 & 18 & 2.6 & ND \\
\hline & & BAMW12M-W-22685 & $7 / 10 / 08$ & 27 & 4.2 & ND \\
\hline & & BAMW12M-W-27736 & $10 / 22 / 08$ & 18 & 4.5 & ND \\
\hline & & BAMW12M-W-22719 & $3 / 4 / 09$ & 25 & 4.4 & ND \\
\hline & & BAMW12M-W-28655 & 6/19/09 & 28 & 4.9 & ND \\
\hline & & BAMW12M-W-28694 & $10 / 1 / 09$ & 26 & 5.1 & ND \\
\hline \multirow[t]{8}{*}{ MW12D } & $115-125$ & BAMW12D-W-22576 & $4 / 5 / 07$ & $0.6 \mathrm{~J}$ & ND & ND \\
\hline & & BAMW12D-W-22610 & $11 / 18 / 07$ & 1.6 & ND & ND \\
\hline & & BAMW12D-W-22641 & $3 / 9 / 08$ & 1.0 & ND & ND \\
\hline & & BAMW12D-W-22686 & $7 / 11 / 08$ & $0.7 \mathrm{~J}$ & ND & ND \\
\hline & & BAMW12D-W-27737 & $10 / 22 / 08$ & $0.9 \mathrm{~J}$ & ND & ND \\
\hline & & BAMW12D-W-22757 & $3 / 4 / 09$ & $0.7 \mathrm{~J}$ & ND & ND \\
\hline & & BAMW12D-W-28656 & $6 / 19 / 09$ & ND & ND & ND \\
\hline & & BAMW12D-W-28695 & $10 / 1 / 09$ & 1.5 & ND & ND \\
\hline \multirow[t]{8}{*}{ MW13S } & $112-122$ & BAMW13S-W-22575 & $4 / 5 / 07$ & 21 & 1.6 & ND \\
\hline & & BAMW13S-W-22611 & $11 / 19 / 07$ & 17 & 1.8 & ND \\
\hline & & BAMW13S-W-22650 & $3 / 10 / 08$ & 17 & 1.5 & ND \\
\hline & & BAMW13S-W-22687 & $7 / 9 / 08$ & 17 & 1.9 & ND \\
\hline & & BAMW13S-W-27738 & $10 / 22 / 08$ & 20 & 1.6 & ND \\
\hline & & BAMW13S-W-22758 & $3 / 4 / 09$ & 14 & 1.1 & ND \\
\hline & & BAMW13S-W-28657 & 6/18/09 & 16 & 1.1 & ND \\
\hline & & BAMW13S-W-28696 & $9 / 30 / 09$ & 12 & $0.9 \mathrm{~J}$ & ND \\
\hline \multirow[t]{8}{*}{ MW13D } & $127-137$ & BAMW13D-W-22574 & $4 / 5 / 07$ & 3.5 & $0.4 \mathrm{~J}$ & ND \\
\hline & & BAMW13D-W-22612 & $11 / 19 / 07$ & 5.9 & $0.2 \mathrm{~J}$ & ND \\
\hline & & BAMW13D-W-22645 & $3 / 9 / 08$ & 11 & 1.1 & ND \\
\hline & & BAMW13D-W-22688 & $7 / 9 / 08$ & 5.9 & $0.9 \mathrm{~J}$ & ND \\
\hline & & BAMW13D-W-27739 & $10 / 22 / 08$ & 6.6 & $0.6 \mathrm{~J}$ & ND \\
\hline & & BAMW13D-W-22759 & $3 / 4 / 09$ & 5.9 & $0.6 \mathrm{~J}$ & ND \\
\hline & & BAMW13D-W-28658 & $6 / 18 / 09$ & 6.2 & ND & ND \\
\hline & & BAMW13D-W-28697 & 9/30/09 & 7.2 & 1.0 & ND \\
\hline \multirow[t]{8}{*}{ MW14S } & $108-118$ & BAMW14S-W-22569 & $4 / 4 / 07$ & $0.9 \mathrm{~J}$ & ND & ND \\
\hline & & BAMW14S-W-22613 & $11 / 18 / 07$ & 1.2 & ND & ND \\
\hline & & BAMW14S-W-22640 & $3 / 8 / 08$ & 4.3 & $0.3 \mathrm{~J}$ & ND \\
\hline & & BAMW14S-W-22689 & $7 / 10 / 08$ & 5.6 & $0.3 \mathrm{~J}$ & ND \\
\hline & & BAMW14S-W-27740 & $10 / 22 / 08$ & 5.6 & $0.3 \mathrm{~J}$ & ND \\
\hline & & BAMW14S-W-28620 & $3 / 4 / 09$ & 5.6 & $0.4 \mathrm{~J}$ & ND \\
\hline & & BAMW14S-W-28659 & $6 / 18 / 09$ & 3.7 & $0.6 \mathrm{~J}$ & ND \\
\hline & & BAMW14S-W-28698 & $10 / 1 / 09$ & 5.2 & $0.3 \mathrm{~J}$ & ND \\
\hline
\end{tabular}


TABLE 4.3 (Cont.)

\begin{tabular}{|c|c|c|c|c|c|c|}
\hline \multirow[b]{2}{*}{ Location } & \multirow[b]{2}{*}{$\begin{array}{l}\text { Depth } \\
\text { (ft BGL) }\end{array}$} & \multirow[b]{2}{*}{ Sample } & \multirow[b]{2}{*}{$\begin{array}{l}\text { Sampling } \\
\text { Date }\end{array}$} & \multicolumn{3}{|c|}{ Concentration $(\mu \mathrm{g} / \mathrm{L})$} \\
\hline & & & & $\begin{array}{c}\text { Carbon } \\
\text { Tetrachloride }\end{array}$ & Chloroform & $\begin{array}{l}\text { Methyle } \\
\text { Chlori }\end{array}$ \\
\hline \multicolumn{7}{|c|}{ CCC/USDA wells installed during the 2006-2007 investigation (cont.) } \\
\hline \multirow[t]{8}{*}{ MW14D } & $123-133$ & BAMW14D-W-22568 & $4 / 4 / 07$ & 1.2 & ND & ND \\
\hline & & BAMW14D-W-22614 & $11 / 18 / 07$ & $0.6 \mathrm{~J}$ & ND & ND \\
\hline & & BAMW14D-W-22638 & $3 / 8 / 08$ & $0.7 \mathrm{~J}$ & ND & ND \\
\hline & & BAMW14D-W-22690 & $7 / 10 / 08$ & $0.5 \mathrm{~J}$ & ND & ND \\
\hline & & BAMW14D-W-27741 & $10 / 22 / 08$ & ND & ND & ND \\
\hline & & BAMW14D-W-28621 & $3 / 5 / 09$ & $0.6 \mathrm{~J}$ & ND & ND \\
\hline & & BAMW14D-W-28660 & $6 / 18 / 09$ & ND & ND & ND \\
\hline & & BAMW14D-W-28699 & 10/1/09 & $0.5 \mathrm{~J}$ & ND & ND \\
\hline \multirow[t]{8}{*}{ MW15S } & $88-98$ & BAMW15S-W-22560 & $4 / 4 / 07$ & 1.5 & ND & ND \\
\hline & & BAMW15S-W-22615 & $11 / 18 / 07$ & 8.7 & $0.4 \mathrm{~J}$ & ND \\
\hline & & BAMW15S-W-22648 & $3 / 10 / 08$ & 1.8 & $0.2 \mathrm{~J}$ & ND \\
\hline & & BAMW15S-W-22691 & $7 / 12 / 08$ & 2.2 & $0.3 \mathrm{~J}$ & ND \\
\hline & & BAMW15S-W-27742 & $10 / 23 / 08$ & 1.9 & ND & ND \\
\hline & & BAMW15S-W-28622 & $3 / 5 / 09$ & 2.5 & ND & ND \\
\hline & & BAMW15S-W-28661 & $6 / 17 / 09$ & 3.2 & $0.5 \mathrm{~J}$ & ND \\
\hline & & BAMW15S-W-28700 & $9 / 29 / 09$ & 2.6 & ND & ND \\
\hline \multirow[t]{8}{*}{ MW15D } & $105-115$ & BAMW15D-W-22561 & $4 / 4 / 07$ & ND & ND & ND \\
\hline & & BAMW15D-W-22616 & $11 / 18 / 07$ & ND & ND & ND \\
\hline & & BAMW15D-W-22631 & $3 / 8 / 08$ & $0.2 \mathrm{~J}$ & ND & ND \\
\hline & & BAMW15D-W-22692 & $7 / 12 / 08$ & ND & ND & ND \\
\hline & & BAMW15D-W-27743 & $10 / 24 / 08$ & ND & ND & ND \\
\hline & & BAMW15D-W-28623 & $3 / 5 / 09$ & ND & ND & ND \\
\hline & & BAMW15D-W-28662 & $6 / 17 / 09$ & ND & ND & ND \\
\hline & & BAMW15D-W-28701 & $9 / 29 / 09$ & ND & ND & ND \\
\hline \multirow[t]{8}{*}{ MW16S } & $76-86$ & BAMW16S-W-22563 & $4 / 4 / 07$ & ND & ND & ND \\
\hline & & BAMW16S-W-22617 & $11 / 19 / 07$ & ND & ND & ND \\
\hline & & BAMW16S-W-22632 & $3 / 7 / 08$ & $0.4 \mathrm{~J}$ & ND & ND \\
\hline & & BAMW16S-W-22693 & $7 / 11 / 08$ & ND & ND & ND \\
\hline & & BAMW16S-W-27744 & $10 / 23 / 08$ & $0.9 \mathrm{~J}$ & ND & ND \\
\hline & & BAMW16S-W-28624 & $3 / 5 / 09$ & 1.4 & ND & ND \\
\hline & & BAMW16S-W-28663 & $6 / 18 / 09$ & 1.6 & ND & ND \\
\hline & & BAMW16S-W-28702 & $9 / 29 / 09$ & 1.7 & ND & ND \\
\hline \multirow[t]{8}{*}{ MW16D } & $90-100$ & BAMW16D-W-22562 & $4 / 4 / 07$ & ND & ND & ND \\
\hline & & BAMW16D-W-22618 & $11 / 19 / 07$ & ND & ND & ND \\
\hline & & BAMW16D-W-22633 & $3 / 7 / 08$ & ND & ND & ND \\
\hline & & BAMW16D-W-22694 & $7 / 11 / 08$ & ND & ND & ND \\
\hline & & BAMW16D-W-27745 & $10 / 23 / 08$ & ND & ND & ND \\
\hline & & BAMW16D-W-28625 & $3 / 5 / 09$ & ND & ND & ND \\
\hline & & BAMW16D-W-28664 & $6 / 18 / 09$ & ND & ND & ND \\
\hline & & BAMW16D-W-28703 & 9/29/09 & ND & ND & ND \\
\hline \multirow[t]{6}{*}{ MW17 } & $120-130$ & BAMW17D-W-22566 & $4 / 4 / 07$ & ND & ND & ND \\
\hline & & BAMW17D-W-22619 & $11 / 19 / 07$ & ND & ND & ND \\
\hline & & BAMW17-W-22634 & $3 / 5 / 08$ & $0.3 \mathrm{~J}$ & ND & ND \\
\hline & & BAMW17-W-22695 & $7 / 9 / 08$ & $0.4 \mathrm{~J}$ & ND & ND \\
\hline & & BAMW17-W-27746 & $10 / 22 / 08$ & $0.7 \mathrm{~J}$ & ND & ND \\
\hline & & BAMW17-W-28626 & $3 / 4 / 09$ & 1.0 & ND & ND \\
\hline
\end{tabular}


Version 01, 04/21/10

TABLE 4.3 (Cont.)

\begin{tabular}{|c|c|c|c|c|c|c|}
\hline \multirow[b]{2}{*}{ Location } & \multirow[b]{2}{*}{$\begin{array}{l}\text { Depth } \\
\text { (ft BGL) }\end{array}$} & \multirow[b]{2}{*}{ Sample } & \multirow[b]{2}{*}{$\begin{array}{l}\text { Sampling } \\
\text { Date }\end{array}$} & \multicolumn{3}{|c|}{ Concentration $(\mu \mathrm{g} / \mathrm{L})$} \\
\hline & & & & $\begin{array}{c}\text { Carbon } \\
\text { Tetrachloride }\end{array}$ & Chloroform & $\begin{array}{l}\text { Methylene } \\
\text { Chloride }\end{array}$ \\
\hline \multicolumn{7}{|c|}{ CCC/USDA wells installed during the 2006-2007 investigation (cont.) } \\
\hline MW17 & $120-130$ & $\begin{array}{l}\text { BAMW17-W-28665 } \\
\text { BAMW17-W-28704 }\end{array}$ & $\begin{array}{l}6 / 17 / 09 \\
9 / 30 / 09\end{array}$ & ND & $\begin{array}{l}\text { ND } \\
\text { ND }\end{array}$ & $\begin{array}{l}\text { ND } \\
\text { ND }\end{array}$ \\
\hline \multicolumn{7}{|c|}{ Private wells } \\
\hline Oentrich & 150 & $\begin{array}{l}\text { BAOENT-W-21693 } \\
\text { BAOENT-W-21713 } \\
\text { BAOENTRICH-W-22579 } \\
\text { BAOENTRICH-W-22622 } \\
\text { BAOENTRICH-W-22654 } \\
\text { BAOENTRICH-W-22695 } \\
\text { BAOENTRICH-W-27747 } \\
\text { BAOENTRICH-W-28627 } \\
\text { BAOENTRICH-W-28666 } \\
\text { BAOENTRICH-W-28705 }\end{array}$ & $\begin{array}{r}7 / 20 / 06 \\
8 / 2 / 06 \\
4 / 5 / 07 \\
11 / 19 / 07 \\
3 / 6 / 08 \\
7 / 11 / 08 \\
10 / 23 / 08 \\
3 / 5 / 09 \\
6 / 18 / 09 \\
9 / 30 / 09\end{array}$ & $\begin{array}{l}0.3 \mathrm{~J} \\
0.6 \mathrm{~J} \\
0.6 \mathrm{~J} \\
0.8 \mathrm{~J} \\
1.3 \\
0.3 \mathrm{~J} \\
0.9 \mathrm{~J} \\
1.1 \\
0.9 \mathrm{~J} \\
1.6\end{array}$ & $\begin{array}{l}\text { ND } \\
\text { ND } \\
\text { ND } \\
\text { ND } \\
\text { ND } \\
\text { ND } \\
\text { ND } \\
\text { ND } \\
\text { ND } \\
\text { ND }\end{array}$ & $\begin{array}{l}\text { ND } \\
\text { ND } \\
\text { ND } \\
\text { ND } \\
\text { ND } \\
\text { ND } \\
\text { ND } \\
\text { ND } \\
\text { ND } \\
\text { ND }\end{array}$ \\
\hline Sedivy & 138 & $\begin{array}{l}\text { BACW-W-21849 } \\
\text { BASED2-W-21913 }\end{array}$ & $\begin{array}{l}8 / 22 / 06 \\
9 / 13 / 06\end{array}$ & $\begin{array}{l}\text { ND } \\
\text { ND }\end{array}$ & $\begin{array}{l}\text { ND } \\
\text { ND }\end{array}$ & $\begin{array}{l}N D \\
N D\end{array}$ \\
\hline Sedivy1 & 90 & Not sampled (well dry) & 9/13/06 & - & - & - \\
\hline Public wa & upply wells & & & & & \\
\hline PWS2 & 155 & $\begin{array}{l}\text { BAPWS2-W-22510 } \\
\text { BAPW2-W-22578 } \\
\text { BAPW2-W-22620 } \\
\text { BAPWS2-W-22655 } \\
\text { BAPWS2-W-22696 } \\
\text { BAPW2-W-27748 } \\
\text { BAPWS2-W-28628 } \\
\text { BAPWS2-W-28667 } \\
\text { BAPWS2-W-28706 } \\
\text { BAPWS2-W-28715 }\end{array}$ & $\begin{array}{r}3 / 9 / 07 \\
4 / 5 / 07 \\
11 / 20 / 07 \\
3 / 6 / 08 \\
7 / 11 / 08 \\
10 / 23 / 08 \\
3 / 5 / 09 \\
6 / 18 / 09 \\
9 / 30 / 09 \\
12 / 14 / 09\end{array}$ & $\begin{array}{l}\text { ND } \\
\text { ND } \\
\text { ND } \\
\text { ND } \\
0.8 \mathrm{~J} \\
1.7 \\
0.9 \mathrm{~J} \\
1.0 \\
\text { ND } \\
\text { ND }\end{array}$ & $\begin{array}{l}\text { ND } \\
\text { ND } \\
\text { ND } \\
\text { ND } \\
\text { ND } \\
\text { ND } \\
\text { ND } \\
\text { ND } \\
\text { ND } \\
\text { ND }\end{array}$ & $\begin{array}{l}\text { ND } \\
\text { ND } \\
\text { ND } \\
\text { ND } \\
\text { ND } \\
\text { ND } \\
\text { ND } \\
\text { ND } \\
\text { ND } \\
\text { ND }\end{array}$ \\
\hline PWS3 & 160 & $\begin{array}{l}\text { BAPWS3-W-22511 } \\
\text { BAPW3-W-22577 } \\
\text { BAPW3-W-22621 } \\
\text { BAPWS3-W-22656 } \\
\text { BAPWS3-W-22697 } \\
\text { BAPW3-W-27749 } \\
\text { BAPWS3-W-28629 } \\
\text { BAPWS3-W-28668 } \\
\text { BAPWS3-W-28707 } \\
\text { BAPWS3-W-28716 }\end{array}$ & $\begin{array}{r}3 / 9 / 07 \\
4 / 5 / 07 \\
11 / 20 / 07 \\
3 / 6 / 08 \\
7 / 11 / 08 \\
10 / 23 / 08 \\
3 / 5 / 09 \\
6 / 18 / 09 \\
9 / 30 / 09 \\
12 / 14 / 09\end{array}$ & $\begin{array}{l}0.2 \mathrm{~J} \\
\text { ND } \\
\text { ND } \\
\text { ND } \\
0.2 \mathrm{~J} \\
\text { ND } \\
\text { ND } \\
\text { ND } \\
\text { ND } \\
\text { ND }\end{array}$ & $\begin{array}{l}\text { ND } \\
\text { ND } \\
\text { ND } \\
\text { ND } \\
\text { ND } \\
\text { ND } \\
\text { ND } \\
\text { ND } \\
\text { ND } \\
\text { ND }\end{array}$ & $\begin{array}{l}\text { ND } \\
\text { ND } \\
N D \\
N D \\
N D \\
N D \\
N D \\
N D \\
N D \\
N D\end{array}$ \\
\hline
\end{tabular}


TABLE 4.3 (Cont.)

a ND, contaminant not detected at an instrument detection limit of $0.1 \mu \mathrm{g} / \mathrm{L}$.

b Qualifier J indicates an estimated concentration below the purge-and-trap method quantitation limit of $1.0 \mu \mathrm{g} / \mathrm{L}$.

c Pumping status of public wells:

\begin{tabular}{|c|c|}
\hline $\begin{array}{c}\text { Sampling } \\
\text { Date }\end{array}$ & PWS2 \\
\hline $3 / 9 / 07$ & Well has been pumping today. \\
\hline $4 / 5 / 07$ & Sampled after letting run for 5-10 min. \\
\hline $11 / 20 / 07$ & Well on at time of sampling. \\
\hline $3 / 6 / 08$ & $\begin{array}{l}\text { Let water run from tap for } 2-3 \text { min, then } \\
\text { sampled. }\end{array}$ \\
\hline $7 / 11 / 08$ & Running for $30 \mathrm{~min}$. \\
\hline $10 / 23 / 08$ & Well was pumping for $5 \mathrm{~min}$. \\
\hline $3 / 5 / 09$ & $\begin{array}{l}\text { Well operating to fill water tower prior to } \\
\text { sampling. }\end{array}$ \\
\hline $6 / 18 / 09$ & $\begin{array}{l}\text { Well pumping since } 6 \text { a.m. on June } 18 \text {. Let } \\
\text { run from tap for } 5 \text { min, then sampled. }\end{array}$ \\
\hline $9 / 30 / 09$ & $\begin{array}{l}\text { Well used on September 29. Let well run for } \\
10 \text { min, then sampled. }\end{array}$ \\
\hline $12 / 14 / 09$ & Well has been pumping today. \\
\hline
\end{tabular}

PWS3

Well has been pumping today.

Well has been pumping all day.

Well on at time of sampling.

Sample collected from tap in well house. Let water run from tap for 2-3 min, then sampled.

Running for 30 min.

Well was pumping for $30 \mathrm{~min}$.

Ran for 5 min.

Well was used on June 17. Let pump run for 10 min, then sampled.

Well in use. Let tap run for $5 \mathrm{~min}$, then sampled.

Well has been pumping today. 


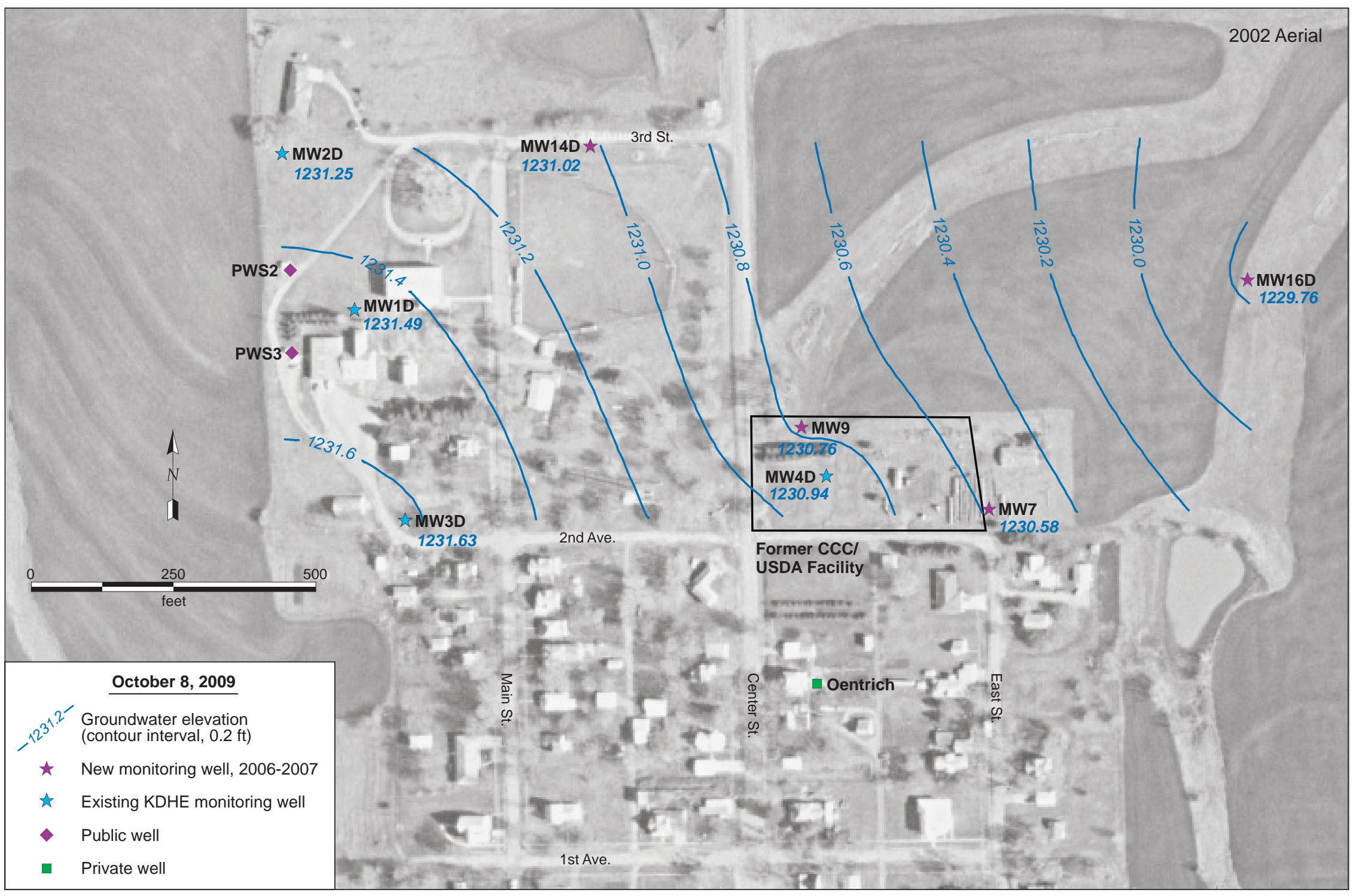

FIGURE 4.1a Potentiometric surface map depicting the groundwater flow direction in the deeper aquifer zone at Barnes under static (nonpumping) conditions on October 8, 2009. Source of photograph: NAPP (2002). 


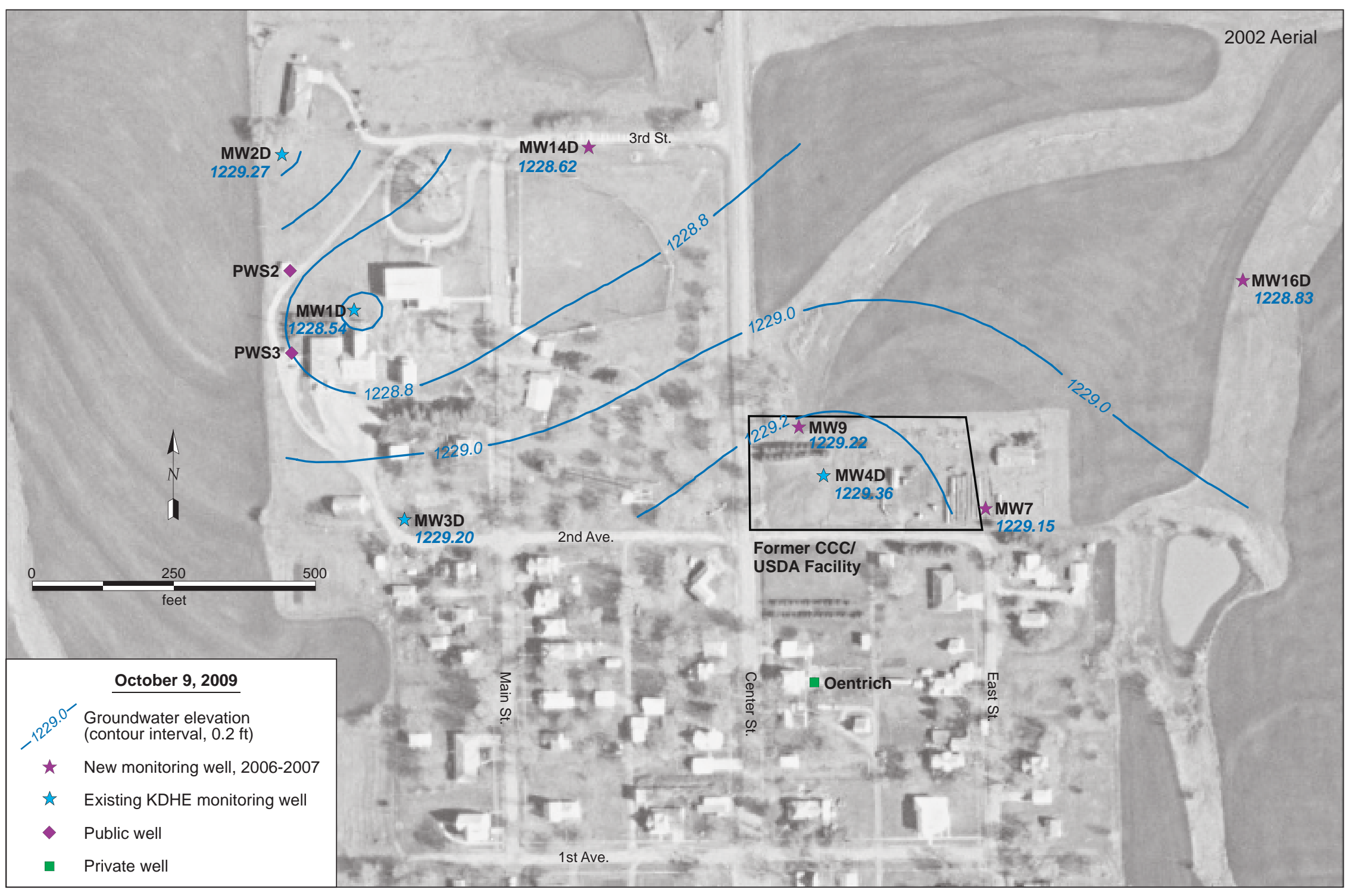

FIGURE 4.1b Potentiometric surface map depicting the groundwater flow direction in the deeper aquifer zone at Barnes under pumping conditions on October 9, 2009. Source of photograph: NAPP (2002). 

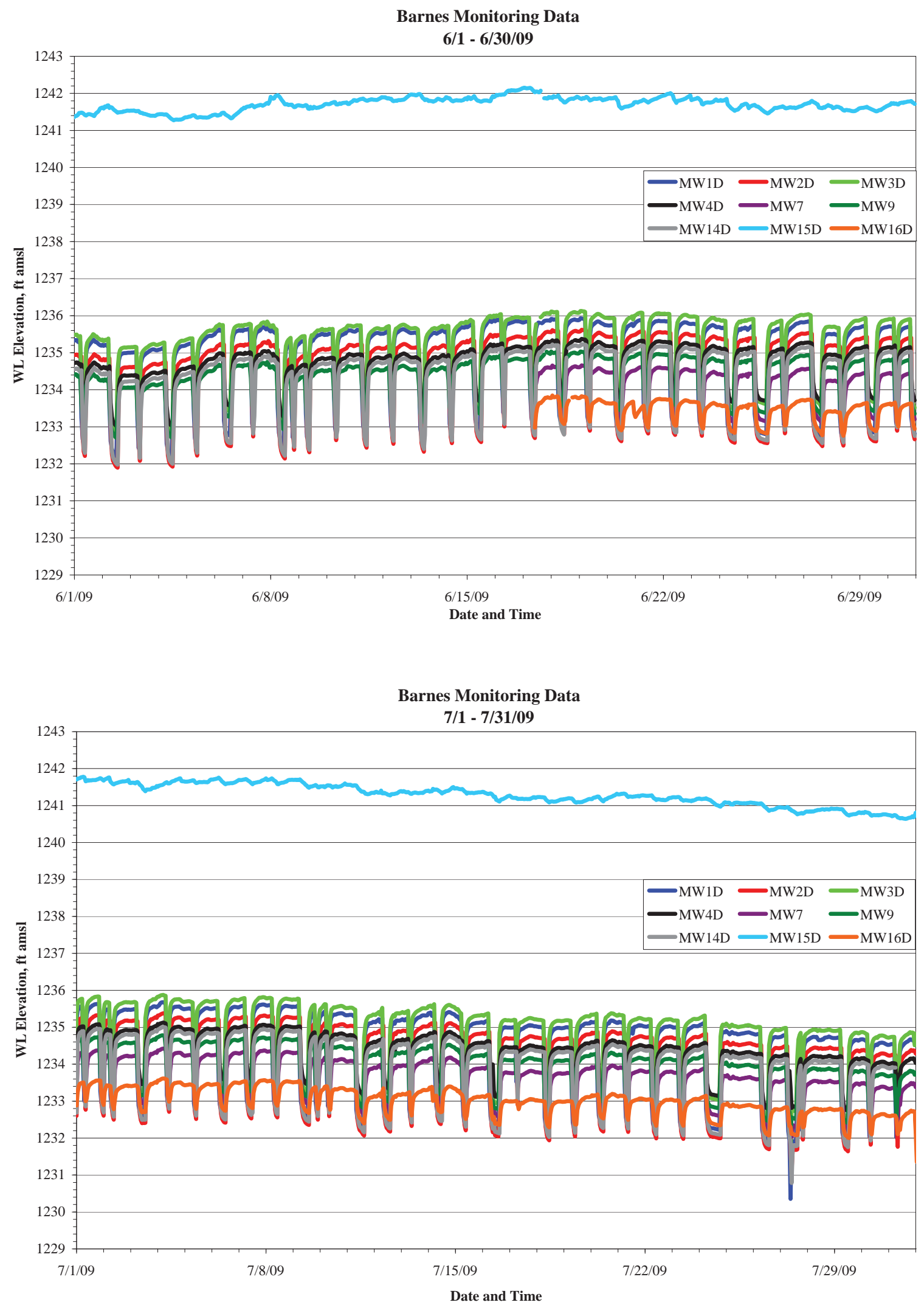

FIGURE 4.2a Hydrographs summarizing monthly results of long-term water level monitoring in the deep-zone wells at Barnes, June-December 2009. 

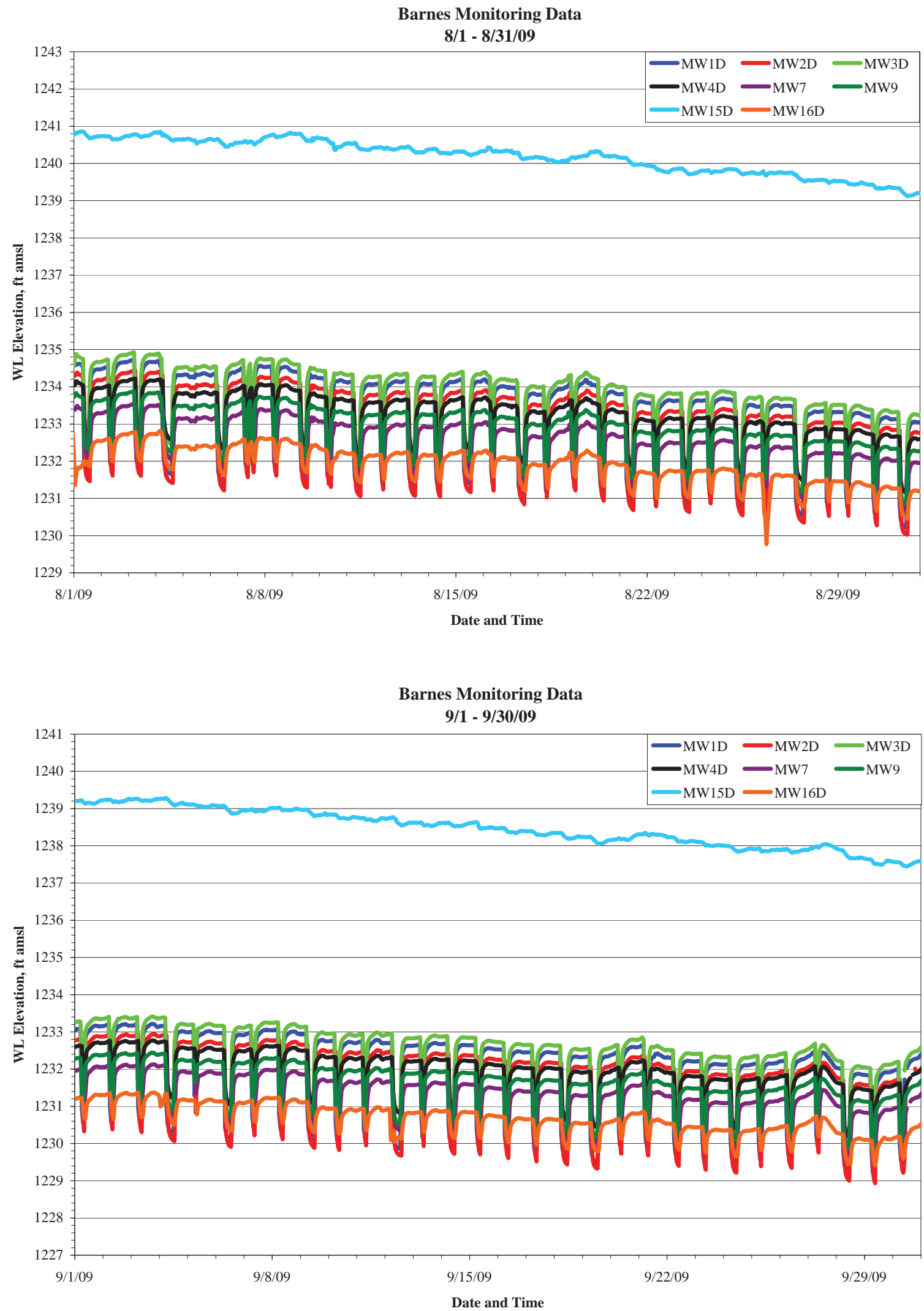

FIGURE 4.2a (Cont.) 

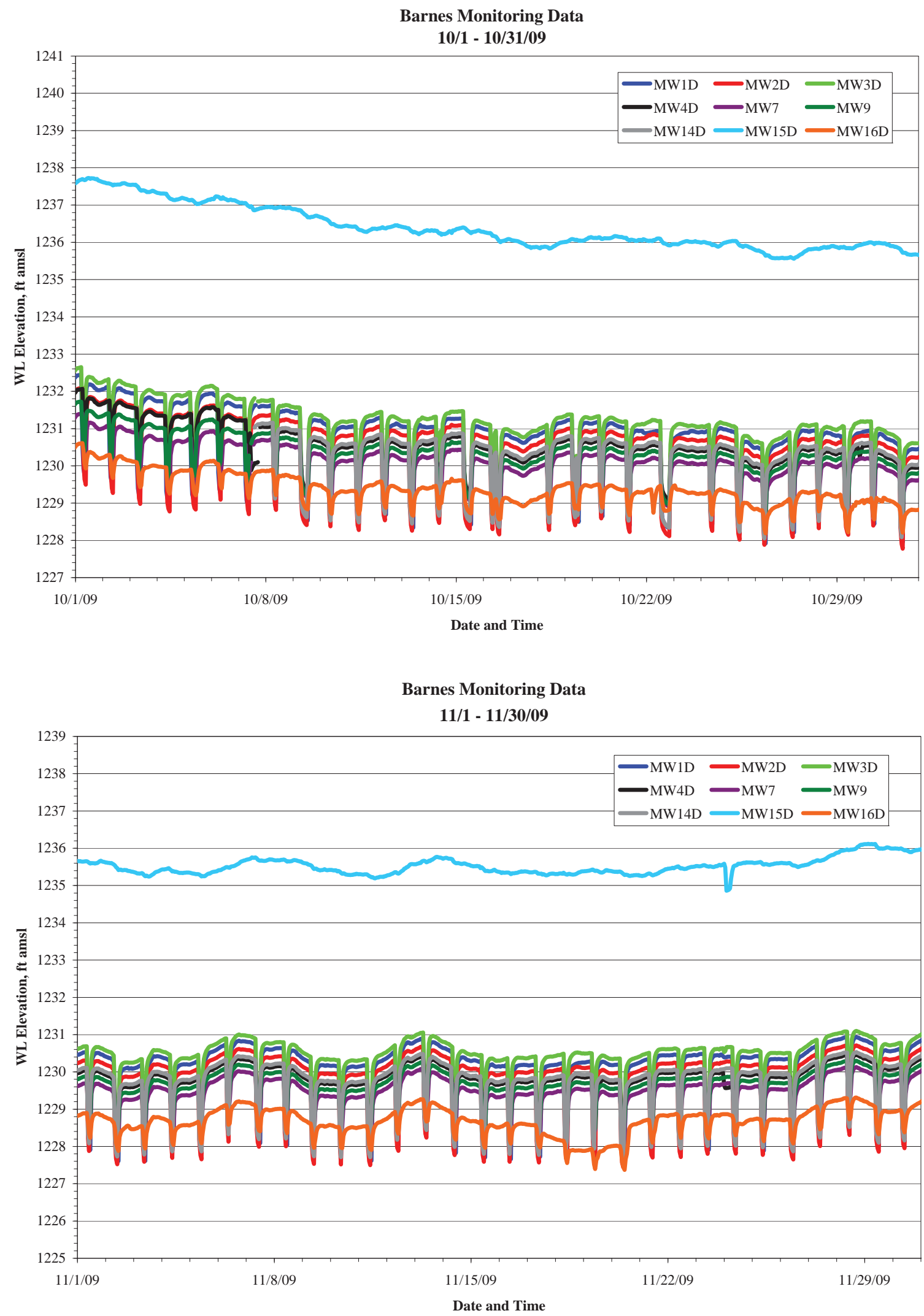

FIGURE 4.2a (Cont.) 
Barnes Monitoring Data

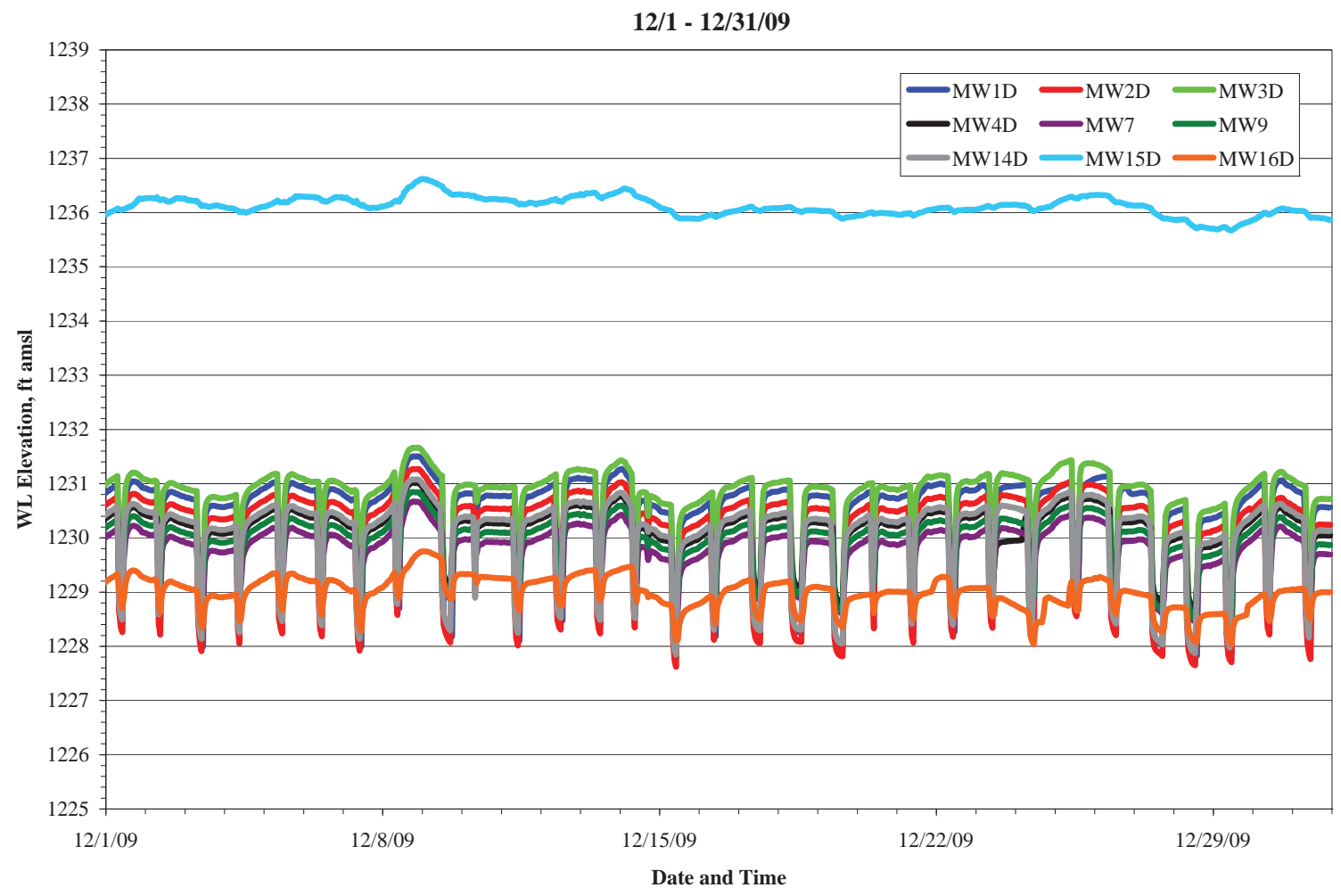

FIGURE 4.2a (Cont.) 
Barnes Monitoring Data

6/1 - 6/30/09

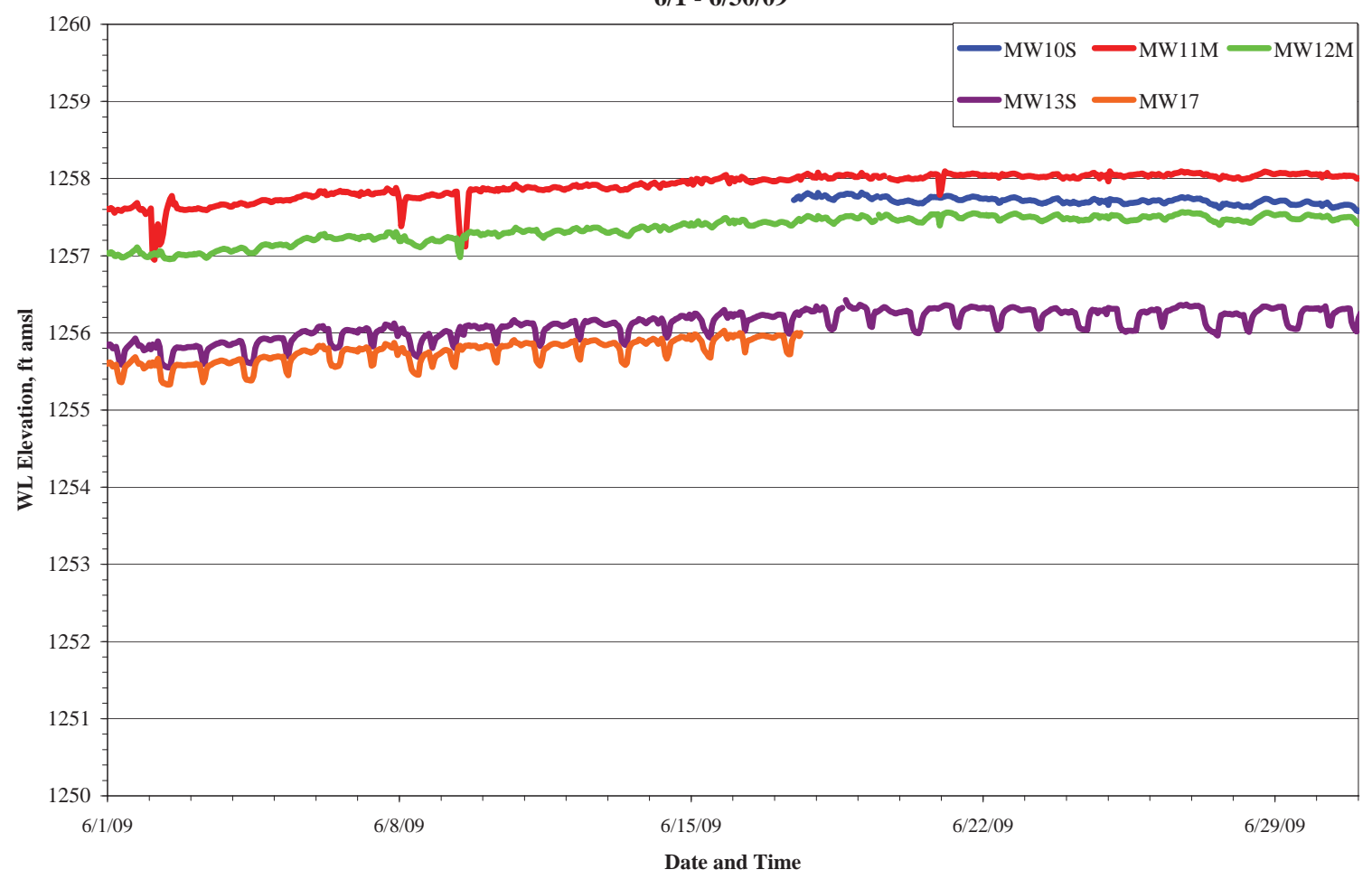

Barnes Monitoring Data

$7 / 1-7 / 31 / 09$

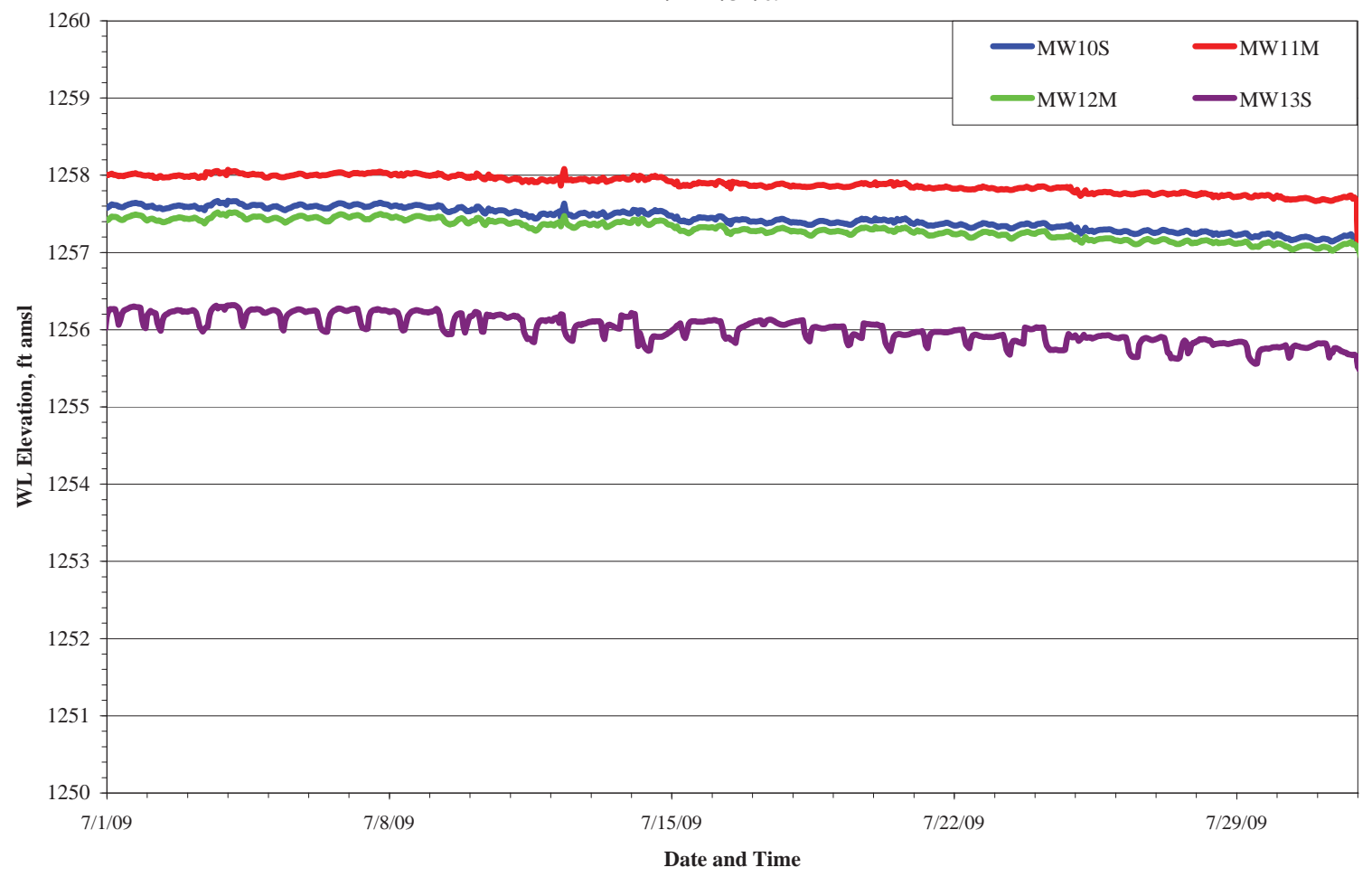

FIGURE 4.2b Hydrographs summarizing monthly results of long-term water level monitoring in the intermediate-zone wells at Barnes, June-December 2009. 
Barnes Monitoring Data

8/1 - 8/31/09

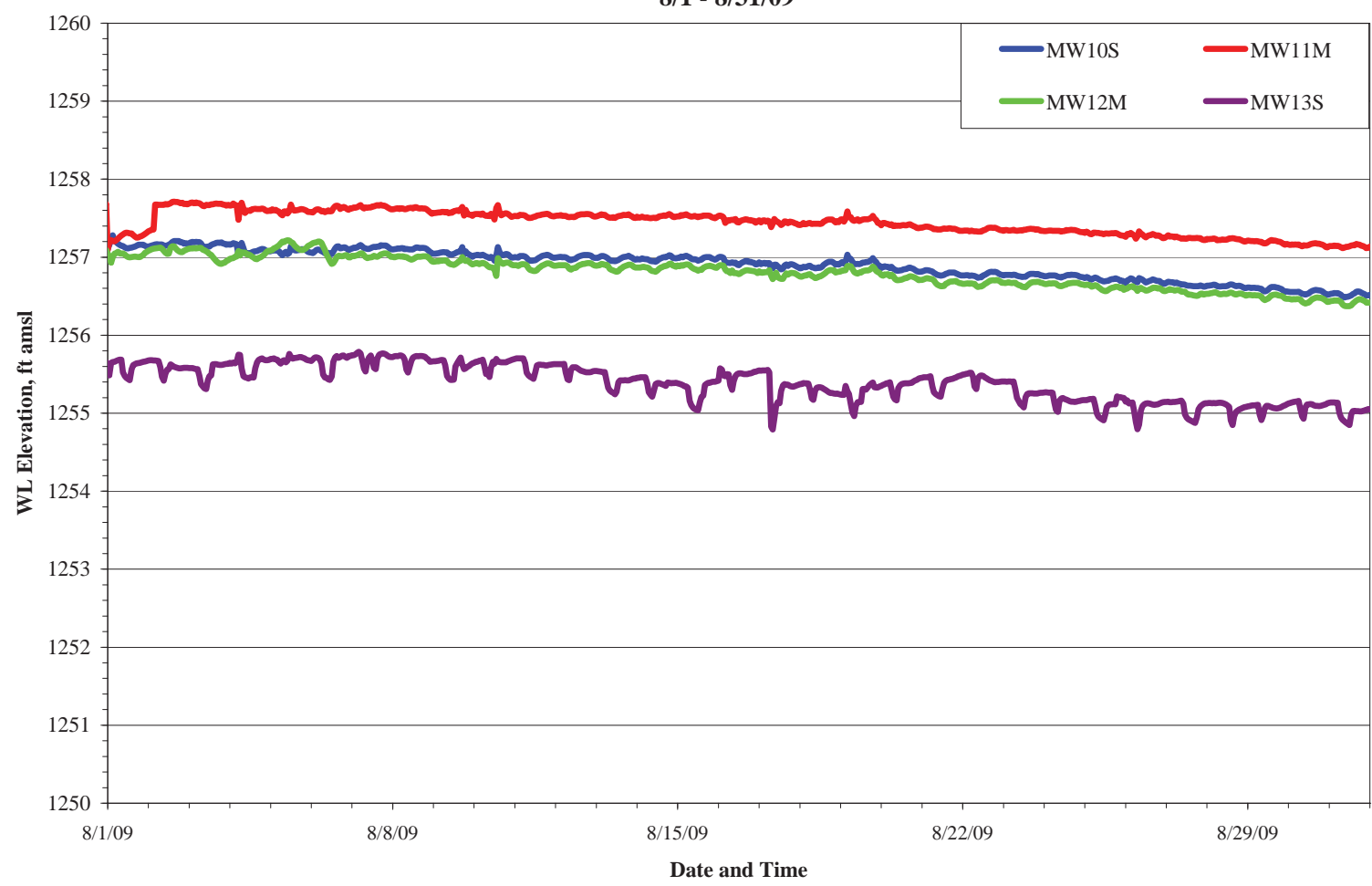

Barnes Monitoring Data

9/1 - 9/30/09

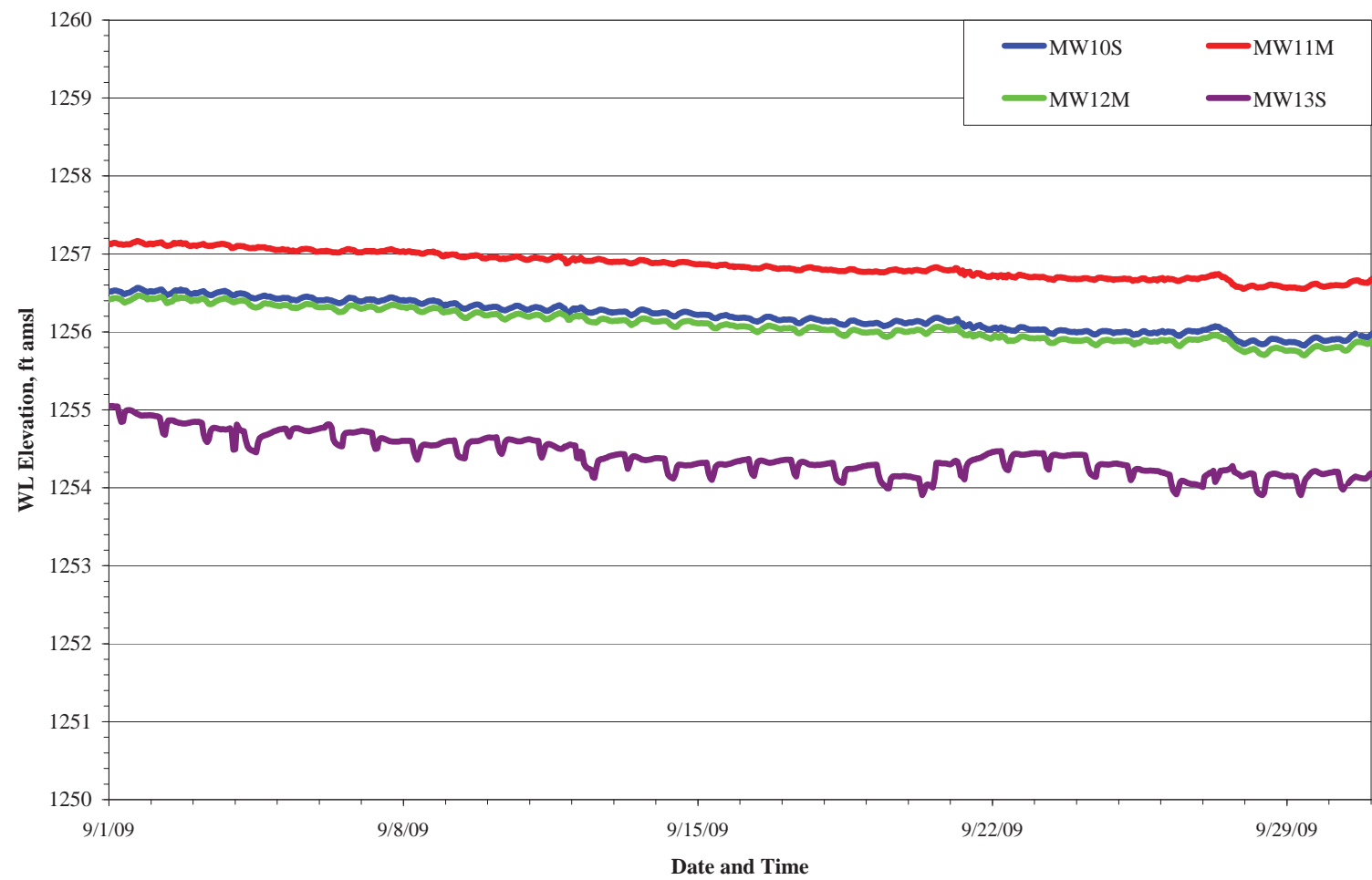

FIGURE 4.2b (Cont.) 
Barnes Monitoring Data

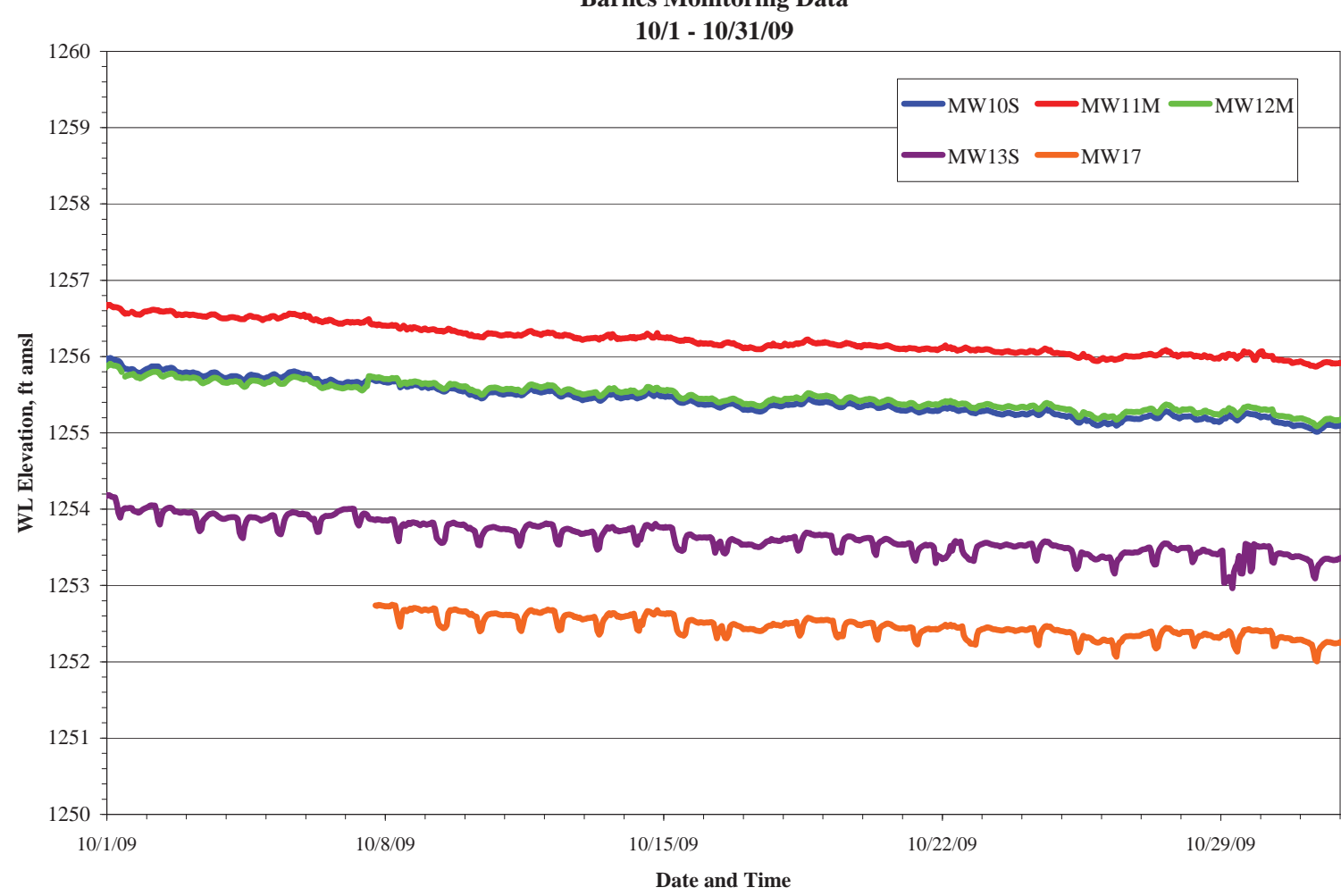

Barnes Monitoring Data

11/1 - 11/30/09

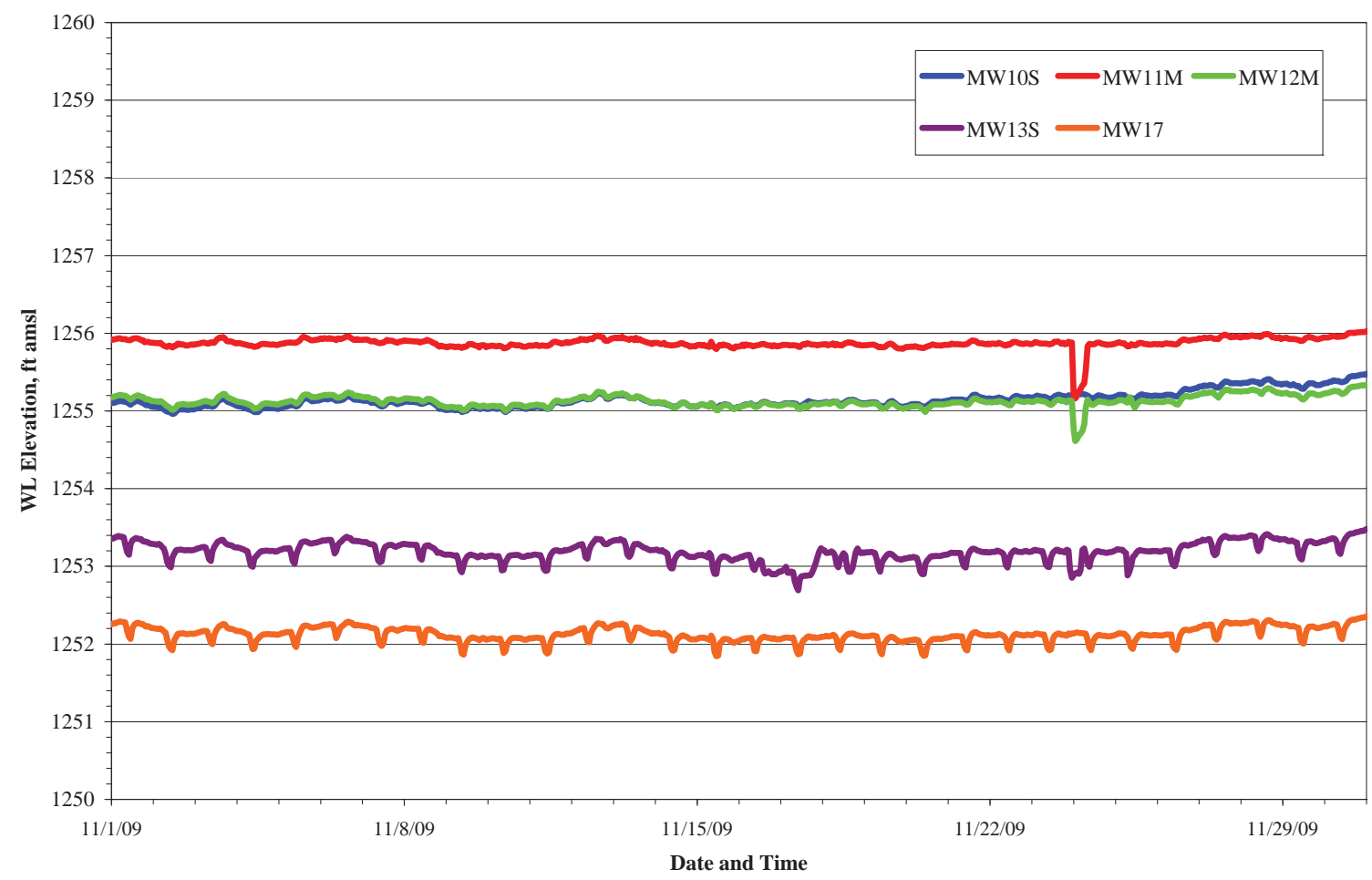

FIGURE 4.2b (Cont.) 
Barnes Monitoring Data

12/1 - 12/31/09

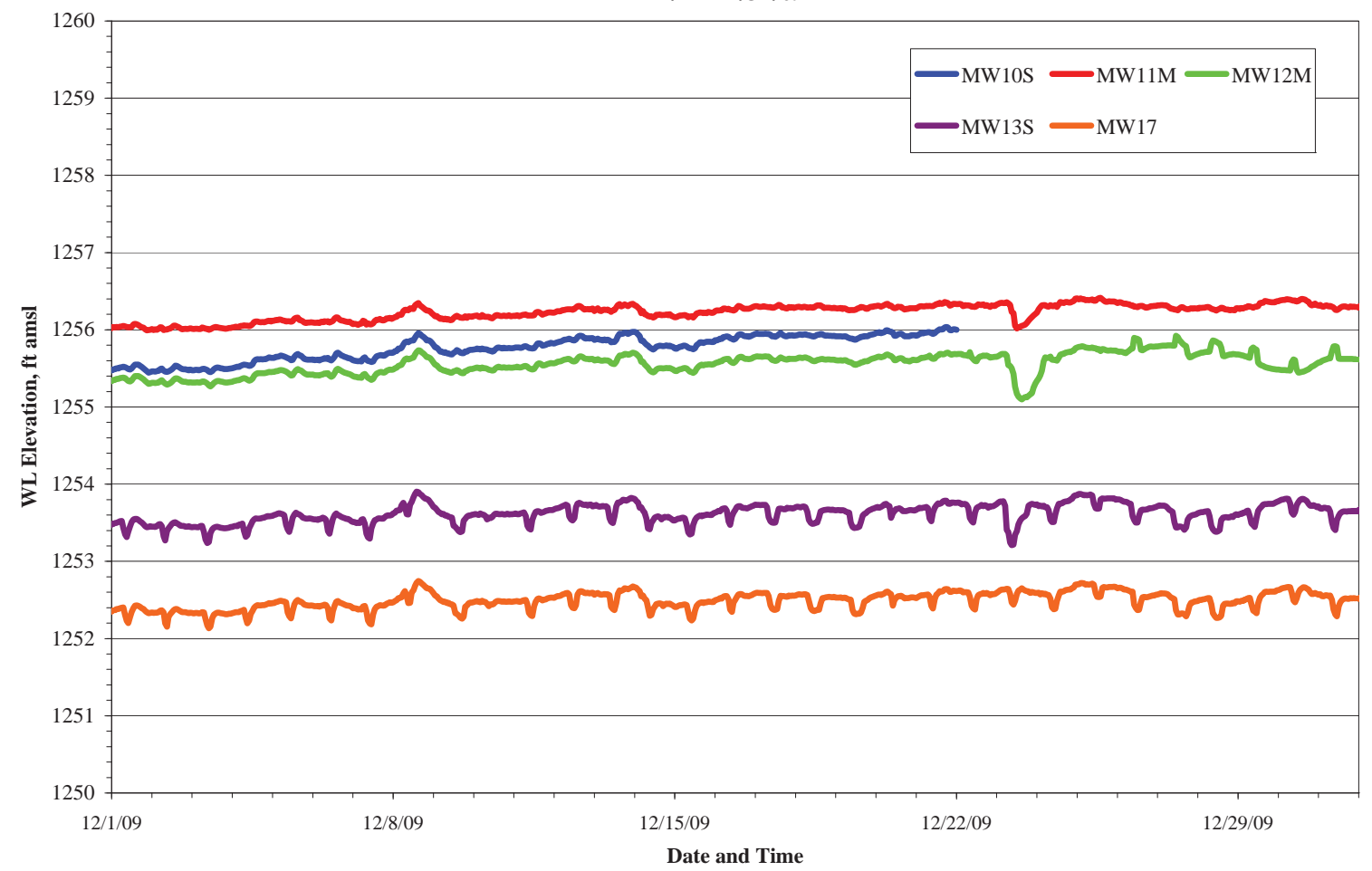

FIGURE 4.2b (Cont.) 


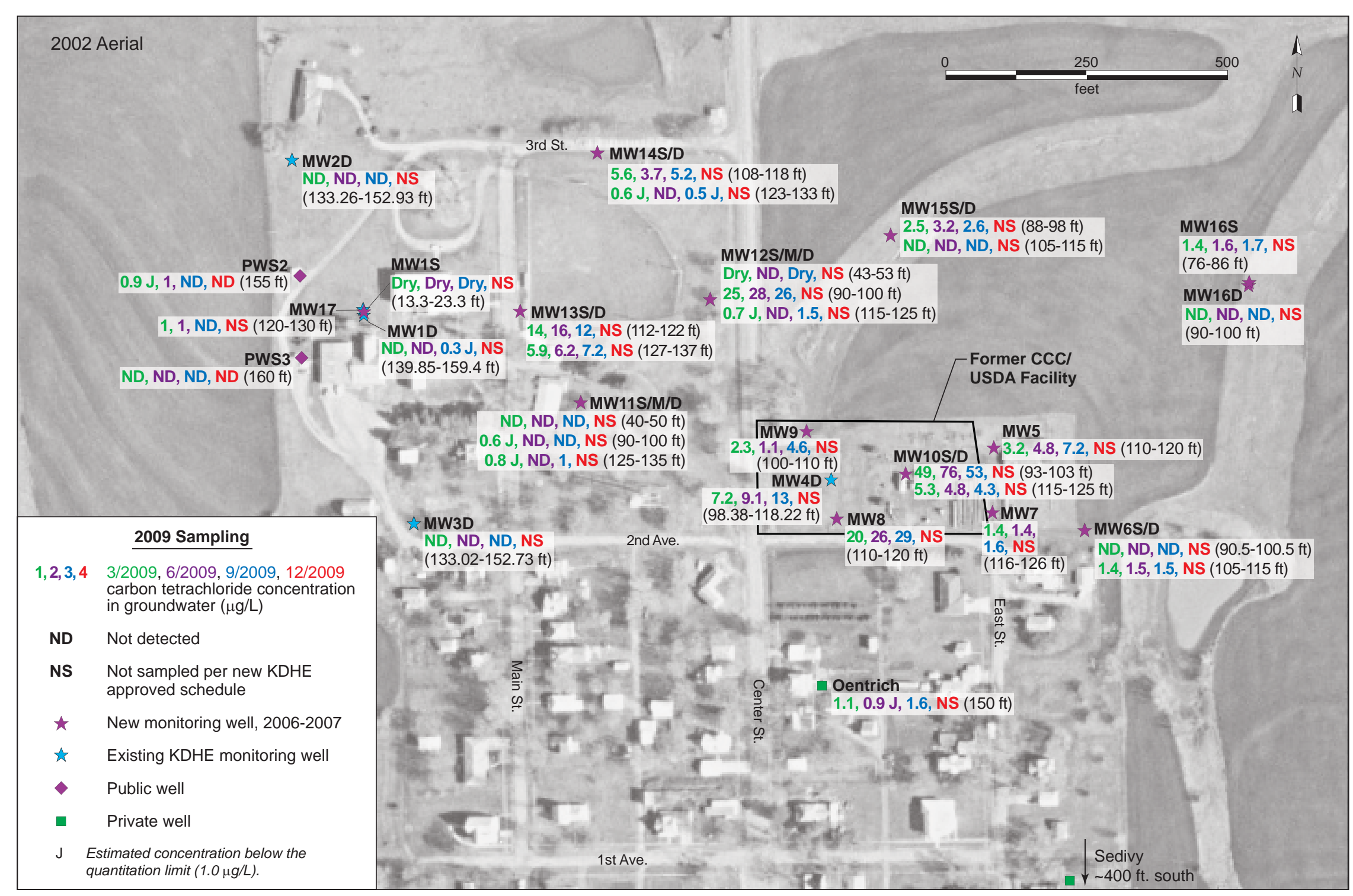

FIGURE 4.3 Analytical results for carbon tetrachloride in groundwater samples collected at Barnes in 2009. Source of photograph: NAPP (2002). 


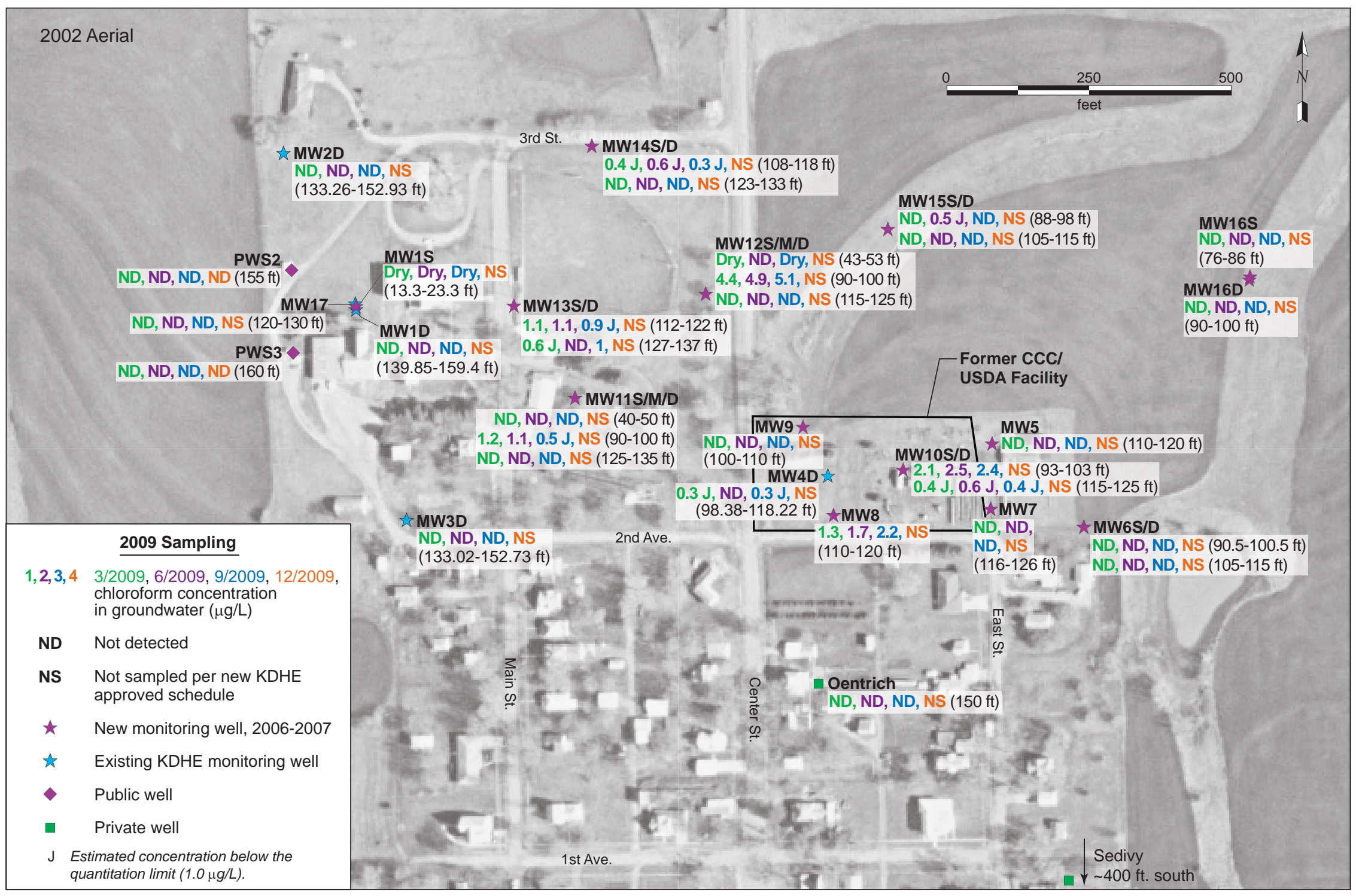

FIGURE 4.4 Analytical results for chloroform in groundwater samples collected at Barnes in 2009. Source of photograph: NAPP (2002). 


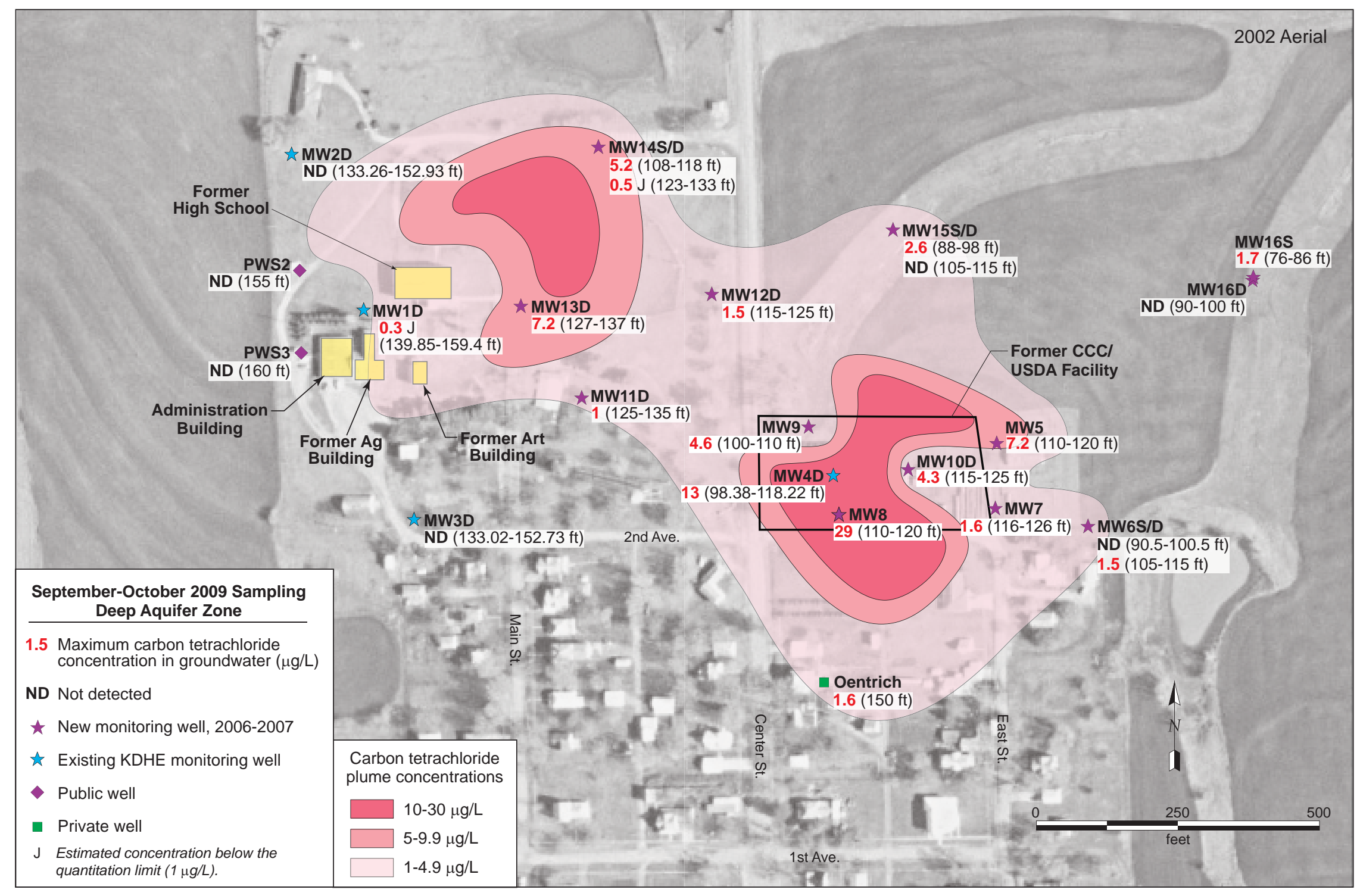

FIGURE 4.5 Interpreted carbon tetrachloride plume in September-October 2009 in wells screened in the deep aquifer zone (groundwater levels approximately 1,229-1,237 ft AMSL). Source of photograph: NAPP (2002). 


\section{Conclusions and Ongoing Tasks}

\subsection{Conclusions}

The findings of the monitoring events at Barnes in July-December 2009 continued to support the following conclusions:

- Measurements of groundwater levels obtained manually and through the use of automatic recorders have consistently indicated that the flow direction is strongly influenced by pumping of the public water supply wells. The results have demonstrated

- An apparent groundwater flow direction to the northeast when the public wells are not pumping and

- A northwesterly groundwater flow trend when the public wells are pumping.

- Evaluation of manual water level measurements and carbon tetrachloride concentrations continues to suggest that three vertically distinguishable aquifer zones are present at Barnes: shallow, intermediate, and deep. All 5 monitoring wells screened in the intermediate aquifer zone and 9 of 20 wells completed in the deep aquifer zone continue to be monitored with automatic water level recorders.

- The vertical distribution of the carbon tetrachloride in groundwater continues to indicate that the highest concentrations occur in the intermediate aquifer zone. Lower concentrations have been detected in the deep aquifer zone, and no carbon tetrachloride has been detected in the shallow zone.

- The conceptual model of the groundwater flow system at Barnes, as previously postulated on the basis of the accumulated results, suggests that the observed vertical hydraulic gradients and higher carbon tetrachloride concentrations in the intermediate zone might reflect generally lower 
permeability and hence less effective groundwater and contaminant migration in the intermediate zone than in the deep aquifer zone.

- As it has since March 2008, intermediate-zone well MW10S, in the eastern portion of the former CCC/USDA facility, contained the highest concentrations of carbon tetrachloride.

- Overall, the lateral distribution of carbon tetrachloride in groundwater in JulyDecember 2009 is similar to the distribution during previous sampling events. The most significant finding is the absence of carbon tetrachloride in public well PWS2.This finding is a change from values of $1.7 \mu \mathrm{g} / \mathrm{L}$ in October 2008, $<1 \mu \mathrm{g} / \mathrm{L}$ in March 2009, and $1.0 \mu \mathrm{g} / \mathrm{L}$ in June 2009 to results of "not detected” in September and December 2009. No contamination was detected in public well PWS3, as has been the case with only two exceptions during Argonne's monitoring. The exceptions for PWS3 are carbon tetrachloride concentrations of $0.2 \mu \mathrm{g} / \mathrm{L}$ on two occasions: March 9, 2007, and July 11, 2008.

\subsection{Ongoing Tasks}

Ongoing tasks related to Barnes are as follows:

- Communication with the city is continuing with regard to a schedule for potential water tower repair or maintenance. The observed effects of pumping on the groundwater flow direction (Section 5.1) suggest that continuous pumping of the public wells while the storage facility is unavailable could affect the pattern of contaminant distribution.

- The trend analysis requested by the KDHE (2009) is in Appendix E. The analysis addresses all of the monitoring wells sampled regularly since 2006, the Oentrich private well, and the public water supply wells. The identified trends in contaminant values and distribution will continue to be monitored, and the analysis will be updated as appropriate. 
- A conceptual contingent interim measure work plan is in place for the use of granular activated carbon system for protection of the public water supply wells (Argonne 2009c).

\subsection{Recommendations}

- As the KDHE (2009) noted, sampling results to date have shown little change in carbon tetrachloride concentrations with time at most of the monitored Barnes locations. We recommend termination of sampling in a number of wells, reducing the monitoring network to the following set:

Intermediate-Zone Wells:

MW10S On former CCC/USDA property

MW12M On possible migration path

MW13S On possible migration path

MW17 Public water supply sentinel well

Deep-Zone Wells:

MW8 On former CCC/USDA property

MW10D On former CCC/USDA property

MW13D On pumping-induced migration path

MW1D Public water supply sentinel well 


\section{Background Well:}

MW2D North of public supply wells

These wells (Figure 5.1) were selected on the basis of their locations and/or the trends observed in the trend analysis (Appendix E).

- We further recommend a change in monitoring frequency to annual for the monitoring wells identified above and to semi-annual for the public water supply wells. We propose to coordinate sampling schedules for the public wells so that the annual sampling by the city of Barnes serves as one of the two annual events and our sampling serves as the other. 


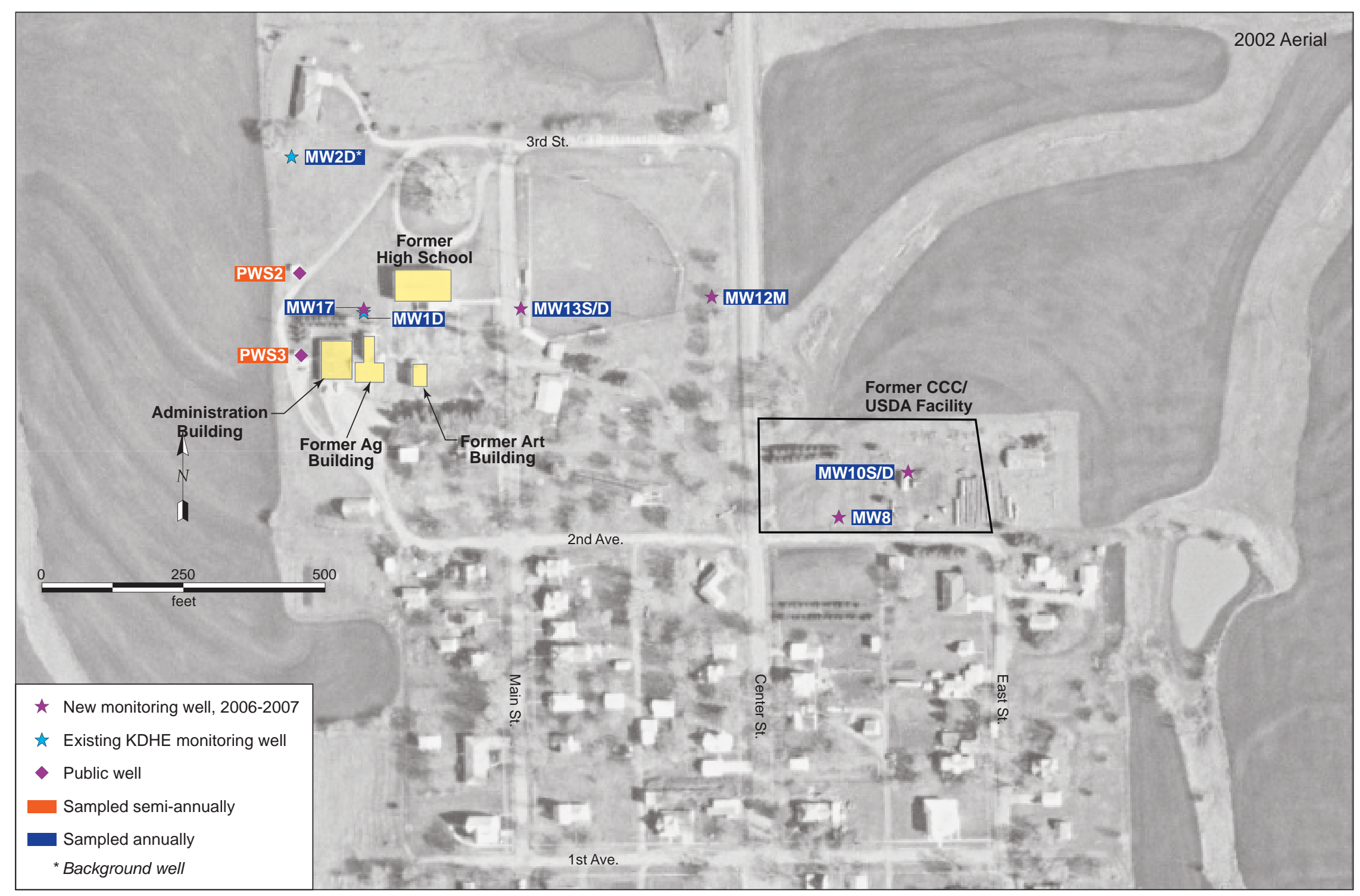

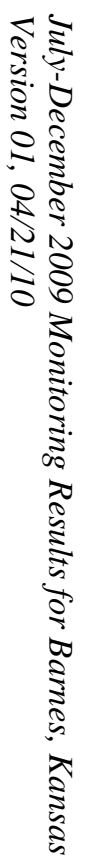

FIGURE 5.1 Wells proposed for ongoing sampling. 


\section{References}

Argonne, 2002, Final Master Work Plan: Environmental Investigations at Former CCC/USDA Facilities in Kansas, 2002 Revision, ANL/ER/TR-02/004, prepared for the Commodity Credit Corporation, U.S. Department of Agriculture, Washington, D.C., by Argonne National Laboratory, Argonne, Illinois, December.

Argonne, 2008a, Final Report: Results of the 2006-2007 Investigation of Potential Contamination at the Former CCC/USDA Facility in Barnes, Kansas, ANL/EVS/AGEM/TR-0712, prepared for the Commodity Credit Corporation, U.S. Department of Agriculture, Washington, D.C., by Argonne National Laboratory, Argonne, Illinois, August.

Argonne, 2008b, November 2007 Monitoring Results for Barnes, Kansas, ANL/EVS/AGEM/TR-08-04, prepared for the Commodity Credit Corporation, U.S. Department of Agriculture, Washington, D.C., by Argonne National Laboratory, Argonne, Illinois, February.

Argonne, 2008c, March 2008 Monitoring Results for Barnes, Kansas, ANL/EVS/AGEM/TR-0811, prepared for the Commodity Credit Corporation, U.S. Department of Agriculture, Washington, D.C., by Argonne National Laboratory, Argonne, Illinois, August.

Argonne, 2008d, July 2008 Monitoring Results for Barnes, Kansas, ANL/EVS/AGEM/TR-0817, prepared for the Commodity Credit Corporation, U.S. Department of Agriculture, Washington, D.C., by Argonne National Laboratory, Argonne, Illinois, September.

Argonne, 2009a, October 2008 Monitoring Results for Barnes, Kansas, ANL/EVS/AGEM/TR09-04, prepared for the Commodity Credit Corporation, U.S. Department of Agriculture, Washington, D.C., by Argonne National Laboratory, Argonne, Illinois, February.

Argonne, 2009b, March-June 2009 Monitoring Results for Barnes, Kansas, ANL/EVS/AGEM/TR-09-09, prepared for the Commodity Credit Corporation, U.S. Department of Agriculture, Washington, D.C., by Argonne National Laboratory, Argonne, Illinois, February.

Argonne, 2009c, Contingency Interim Measure for the Public Water Supply at Barnes, Kansas, ANL/EVS/AGEM/TR-08-19, prepared for the Commodity Credit Corporation, U.S. Department of Agriculture, Washington, D.C., by Argonne National Laboratory, Argonne, Illinois, June. 
EPA, 1995, Method 524.2: Measurement of Purgeable Organic Compounds in Water by Capillary Column Gas Chromatography/Mass Spectrometry, Revision 4.1, edited by J.W. Munch, National Exposure Research Laboratory, Office of Research and Development, U.S. Environmental Protection Agency, Cincinnati, Ohio.

KDHE, 2009, letter from E. Finzer (Bureau of Environmental Remediation, Kansas Department of Health and Environment, Topeka, Kansas) to C. Roe (Commodity Credit Corporation, U.S. Department of Agriculture, Washington, D.C.), regarding March-June 2009 Monitoring Results for Barnes, Kansas, November 25.

NAPP, 2002, aerial image NAPP 12897 222, National Aerial Photography Program, U.S. Geological Survey (available from Kansas Geospatial Community Commons [http://www.kansasgis.org/]), April 9.

Puls, R.W., and M.J. Barcelona, 1996, "Low-Flow (Minimal Drawdown) Ground-Water Sampling Procedures,” EPA/540/S-95/504, in Ground Water Issue, Superfund Technology Support Center for Ground Water, National Risk Management Research Laboratory, U.S. Environmental Protection Agency, Ada, Oklahoma, April (www.epa.gov/tio/tsp/download/ lwflw2a.pdf).

Yeskis, D., and B. Zavala, 2002, Ground-Water Sampling Guidelines for Superfund and RCRA Project Managers: Ground Water Forum Issue Paper, EPA 542-S-02-001, Technology Innovative Office, Office of Solid Waste and Emergency Response, U.S. Environmental Protection Agency, Washington, D.C., May (http://www.epa.gov/tio/tsp/download/ gw_sampling_guide.pdf). 


\section{Appendix A:}

Sampling Activities and Field Measurements at Barnes in September-October and December 2009 
TABLE A.1 Sequence of sampling activities at Barnes in September-October 2009 quarterly monitoring and December 2009 public well sampling.

\begin{tabular}{|c|c|c|c|c|c|c|c|c|}
\hline $\begin{array}{l}\text { Sample } \\
\text { Date }\end{array}$ & Time & $\begin{array}{l}\text { Sample } \\
\text { Location }\end{array}$ & $\begin{array}{l}\text { Depth } \\
\text { (ft BGL) }\end{array}$ & Sample & $\begin{array}{c}\text { Sample } \\
\text { Type }^{a}\end{array}$ & $\begin{array}{l}\text { Chain of } \\
\text { Custody }\end{array}$ & $\begin{array}{l}\text { Shipping } \\
\text { Date }\end{array}$ & Sample Description \\
\hline 9/29/09 & $16: 32$ & MW15S & 88-98 & BAMW15S-W-28700 & MW & 2606 & 9/30/09 & $\begin{array}{l}\text { Depth to water }=79.45 \mathrm{ft} \text {. Depth of } 2 \text {-in. } \\
\text { well }=98 \mathrm{ft} \text { Sample collected by using } \\
\text { low-flow bladder pump after purging of } \\
9.5 \mathrm{~L} \text {. Pump intake positioned at } 93 \mathrm{ft} \text {. } \\
\text { Aliquots collected for verification analysis } \\
\text { at TestAmerica. }\end{array}$ \\
\hline 9/29/09 & $17: 30$ & MW15D & $105-115$ & BAMW15D-W-28701 & MW & 2606 & 9/30/09 & $\begin{array}{l}\text { Depth to water }=72.1 \mathrm{ft} \text {. Depth of } 2 \text {-in. well }= \\
115 \mathrm{ft} \text {. Sample collected by using low-flow } \\
\text { bladder pump after purging of } 8 \mathrm{~L} \text {. Pump } \\
\text { intake positioned at } 110 \mathrm{ft} \text {. }\end{array}$ \\
\hline 9/29/09 & $18: 28$ & MW16S & $76-86$ & BAMW16S-W-28702 & MW & 2606 & 9/30/09 & $\begin{array}{l}\text { Depth to water }=70.35 \mathrm{ft} \text {. Depth of } 2 \text {-in. } \\
\text { well }=86 \mathrm{ft} \text {. Sample collected by using } \\
\text { low-flow bladder pump after purging of } \\
5 \mathrm{~L} \text {. Pump intake positioned at } 81 \mathrm{ft} \text {. }\end{array}$ \\
\hline 9/29/09 & $18: 40$ & MW16D & $90-100$ & BAMW16D-W-28703 & MW & 2606 & 9/30/09 & $\begin{array}{l}\text { Depth to water }=70.0 \mathrm{ft} \text {. Depth of } 2 \text {-in. well }= \\
100 \mathrm{ft} \text {. Sample collected by using low-flow } \\
\text { bladder pump after purging of } 6 \mathrm{~L} \text {. Pump } \\
\text { intake positioned at } 95 \mathrm{ft} \text {. Aliquots } \\
\text { collected for verification analysis at } \\
\text { TestAmerica. }\end{array}$ \\
\hline 9/29/09 & $19: 30$ & MW9 & $100-110$ & BAMW9-W-28687 & MW & 2606 & 9/30/09 & $\begin{array}{l}\text { Depth to water }=87.1 \mathrm{ft} \text {. Depth of } 2 \text {-in. well }= \\
110 \mathrm{ft} \text {. Sample collected by using low-flow } \\
\text { bladder pump after purging of } 5 \mathrm{~L} \text {. Pump } \\
\text { intake positioned at } 105 \mathrm{ft} \text {. }\end{array}$ \\
\hline 9/30/09 & $9: 44$ & MW3D & $133.02-152.73$ & BAMW3D-W-28680 & MW & 2608 & 9/30/09 & $\begin{array}{l}\text { Depth to water }=116.3 \mathrm{ft} \text {. Depth of } 2 \text {-in. } \\
\text { well }=152.73 \mathrm{ft} \text {. Sample collected by } \\
\text { using low-flow bladder pump after purging } \\
\text { of } 5.5 \mathrm{~L} \text {. Pump intake positioned at } \\
142.88 \mathrm{ft} \text {. }\end{array}$ \\
\hline 9/30/09 & 9:45 & MW3D & $133.02-152.73$ & BAMW3DDUP-W-28708 & MW & 2608 & 9/30/09 & Replicate of sample BAMW3D-W-28680. \\
\hline 9/30/09 & 9:55 & PWS2 & 155 & BAPWS2-W-28706 & PW & 2608 & 9/30/09 & $\begin{array}{l}\text { Well used on September 29. Allowed well to } \\
\text { run for } 10 \text { min and then sampled. }\end{array}$ \\
\hline 9/30/09 & 10:03 & PWS3 & 160 & BAPWS3-W-28707 & PW & 2608 & 9/30/09 & $\begin{array}{l}\text { Well in use since } 6 \text { am on September } 30 \text {. Let } \\
\text { tap run for } 5 \text { min and then sampled. } \\
\text { Aliquots collected for verification analysis } \\
\text { at TestAmerica. }\end{array}$ \\
\hline
\end{tabular}


TABLE A.1 (Cont.)

\begin{tabular}{|c|c|c|c|c|c|c|c|c|}
\hline $\begin{array}{l}\text { Sample } \\
\text { Date }\end{array}$ & Time & $\begin{array}{l}\text { Sample } \\
\text { Location }\end{array}$ & $\begin{array}{l}\text { Depth } \\
\text { (ft BGL) }\end{array}$ & Sample & $\begin{array}{c}\text { Sample } \\
\text { Type }^{a}\end{array}$ & $\begin{array}{l}\text { Chain of } \\
\text { Custody }\end{array}$ & $\begin{array}{l}\text { Shipping } \\
\text { Date }\end{array}$ & Sample Description \\
\hline 9/30/09 & 10:05 & MW13D & $127-137$ & BAMW13D-W-28697 & MW & 2608 & 9/30/09 & $\begin{array}{l}\text { Depth to water }=112.85 \mathrm{ft} \text {. Depth of } 2 \text {-in. } \\
\text { well = } 137 \mathrm{ft} \text {. Sample collected by using } \\
\text { low-flow bladder pump after purging of } \\
2 \mathrm{~L} \text {. Pump intake positioned at } 132 \mathrm{ft} \text {. } \\
\text { Aliquots collected for verification analysis } \\
\text { at TestAmerica. }\end{array}$ \\
\hline 9/30/09 & $10: 52$ & MW17 & $120-130$ & BAMW17-W-28704 & MW & 2608 & 9/30/09 & $\begin{array}{l}\text { Depth to water }=98.0 \mathrm{ft} \text {. Depth of } 2 \text {-in. well }= \\
130 \mathrm{ft} \text {. Sample collected by using low-flow } \\
\text { bladder pump after purging of } 5.8 \mathrm{~L} \text {. } \\
\text { Pump intake positioned at } 125 \mathrm{ft} \text {. Aliquots } \\
\text { collected for verification analysis at } \\
\text { TestAmerica. }\end{array}$ \\
\hline 9/30/09 & $11: 16$ & MW13S & $112-122$ & BAMW13S-W-28696 & MW & 2608 & 9/30/09 & $\begin{array}{l}\text { Depth to water }=88.45 \mathrm{ft} \text {. Depth of } 2 \text {-in. } \\
\text { well }=122 \mathrm{ft} \text {. Sample collected by using } \\
\text { low-flow bladder pump after purging of } \\
3.5 \text { L. Pump intake positioned at } 117 \mathrm{ft} \text {. }\end{array}$ \\
\hline 9/30/09 & $12: 09$ & MW1D & $139.85-159.4$ & BAMW1D-W-28678 & MW & 2608 & 9/30/09 & $\begin{array}{l}\text { Depth to water = } 120.4 \mathrm{ft} \text {. Depth of } 2 \text {-in. well } \\
=159.4 \mathrm{ft} \text {. Sample collected by using low- } \\
\text { flow bladder pump after purging of } 4.5 \mathrm{~L} \text {. } \\
\text { Pump intake positioned at } 149.63 \mathrm{ft} \text {. }\end{array}$ \\
\hline 9/30/09 & $12: 20$ & $\mathrm{QC}$ & - & BAQCIR-W-28711 & $\mathrm{RI}$ & 2606 & 9/30/09 & $\begin{array}{l}\text { Rinsate of decontaminated sampling line } \\
\text { after collection of sample BAMW1D-W- } \\
28678 \text {. }\end{array}$ \\
\hline 9/30/09 & $12: 30$ & MW1S & $13.3-23.3$ & BAMW1S-dry-Sep09 & MW & - & - & Well was dry. \\
\hline 9/30/09 & $13: 54$ & Oentrich & 150 & BAOENTRICH-W-28705 & DW & 2608 & 9/30/09 & Purged 10 gal, then sampled. \\
\hline 9/30/09 & $14: 04$ & MW7 & $116-126$ & BAMW7-W-28685 & $\mathrm{MW}$ & 2608 & 9/30/09 & $\begin{array}{l}\text { Depth to water }=99.55 \mathrm{ft} \text {. Depth of } 2 \text {-in. } \\
\text { well = } 126 \mathrm{ft} \text {. Sample collected by using } \\
\text { low-flow bladder pump after purging of } \\
7.5 \mathrm{~L} \text {. Pump intake positioned at } 121 \mathrm{ft} \text {. }\end{array}$ \\
\hline 9/30/09 & $14: 11$ & MW2D & $133.26-152.93$ & BAMW2D-W-28679 & MW & 2608 & 9/30/09 & $\begin{array}{l}\text { Depth to water = } 117.6 \mathrm{ft} \text {. Depth of } 2 \text {-in. } \\
\text { well = } 152.93 \mathrm{ft} \text {. Sample collected by } \\
\text { using low-flow bladder pump after purging } \\
\text { of } 7.5 \mathrm{~L} \text {. Pump intake positioned at } \\
143.10 \mathrm{ft} \text {. }\end{array}$ \\
\hline 9/30/09 & $14: 12$ & MW2D & $133.26-152.93$ & BAMW2DDUP-W-28709 & MW & 2608 & 9/30/09 & Replicate of sample BAMW2D-W-28679. \\
\hline
\end{tabular}


TABLE A.1 (Cont.)

\begin{tabular}{|c|c|c|c|c|c|c|c|c|}
\hline $\begin{array}{l}\text { Sample } \\
\text { Date }\end{array}$ & Time & $\begin{array}{l}\text { Sample } \\
\text { Location }\end{array}$ & $\begin{array}{l}\text { Depth } \\
\text { (ft BGL) }\end{array}$ & Sample & $\begin{array}{l}\text { Sample } \\
\text { Type }^{a}\end{array}$ & $\begin{array}{l}\text { Chain of } \\
\text { Custody }\end{array}$ & $\begin{array}{l}\text { Shipping } \\
\text { Date }\end{array}$ & Sample Description \\
\hline 9/30/09 & $15: 18$ & MW5 & $110-120$ & BAMW5-W-28682 & MW & 2608 & 9/30/09 & $\begin{array}{l}\text { Depth to water }=96.6 \mathrm{ft} \text {. Depth of } 2 \text {-in. well = } \\
120 \mathrm{ft} \text {. Sample collected by using low-flow } \\
\text { bladder pump after purging of } 7 \mathrm{~L} \text {. Pump } \\
\text { intake positioned at } 115 \mathrm{ft} \text {. }\end{array}$ \\
\hline 9/30/09 & $15: 35$ & MW8 & $110-120$ & BAMW8-W-28686 & MW & 2608 & 9/30/09 & $\begin{array}{l}\text { Depth to water }=99.2 \mathrm{ft} \text {. Depth of } 2 \text {-in. well = } \\
120 \mathrm{ft} \text {. Sample collected by using low-flow } \\
\text { bladder pump after purging of } 3.5 \mathrm{~L} \text {. } \\
\text { Pump intake positioned at } 115 \mathrm{ft} \text {. }\end{array}$ \\
\hline 9/30/09 & $16: 16$ & $\mathrm{QC}$ & - & BAQCTB-W-28713 & TB & 2606 & 9/30/09 & $\begin{array}{l}\text { Trip blank sent to the AGEM Laboratory for } \\
\text { organic analysis with water samples listed } \\
\text { on COCs } 2606 \text { and } 2608 \text {, and to } \\
\text { TestAmerica for verification organic } \\
\text { analysis with water samples listed on } \\
\text { COC } 2609 \text {. }\end{array}$ \\
\hline 9/30/09 & $16: 22$ & MW4D & $98.38-118.22$ & BAMW4D-W-28681 & MW & 2608 & 9/30/09 & $\begin{array}{l}\text { Depth to water }=95.7 \mathrm{ft} \text {. Depth of } 2 \text {-in. well }= \\
118.22 \mathrm{ft} \text {. Sample collected by using low- } \\
\text { flow bladder pump after purging of } 6 \mathrm{~L} \text {. } \\
\text { Pump intake positioned at } 108.30 \mathrm{ft} .\end{array}$ \\
\hline $9 / 30 / 09$ & $16: 59$ & MW10S & $93-103$ & BAMW10S-W-28688 & MW & 2597 & 10/2/09 & $\begin{array}{l}\text { Depth to water }=75.65 \mathrm{ft} \text {. Depth of } 2 \text {-in. } \\
\text { well }=103 \mathrm{ft} \text {. Sample collected by using } \\
\text { low-flow bladder pump after purging of } \\
7.5 \mathrm{~L} \text {. Pump intake positioned at } 98 \mathrm{ft} \text {. }\end{array}$ \\
\hline 9/30/09 & 18:05 & MW10D & $115-125$ & BAMW10D-W-28689 & MW & 2597 & 10/2/09 & $\begin{array}{l}\text { Depth to water }=100.45 \mathrm{ft} \text {. Depth of } 2 \text {-in. } \\
\text { well = } 125 \mathrm{ft} \text {. Sample collected by using } \\
\text { low-flow bladder pump after purging of } \\
5 \mathrm{~L} \text {. Pump intake positioned at } 120 \mathrm{ft} \text {. }\end{array}$ \\
\hline 9/30/09 & $18: 30$ & QC & - & BAQCIR-W-28712 & $\mathrm{RI}$ & 2597 & 10/2/09 & $\begin{array}{l}\text { Rinsate of decontaminated sampling line } \\
\text { after collection of sample BAMW10D-W- } \\
28689 \text {. }\end{array}$ \\
\hline 10/1/09 & $10: 43$ & MW12M & $90-100$ & BAMW12M-W-28694 & MW & 2597 & 10/2/09 & $\begin{array}{l}\text { Depth to water }=72.9 \mathrm{ft} \text {. Depth of } 2 \text {-in. well = } \\
100 \mathrm{ft} \text {. Sample collected by using low-flow } \\
\text { bladder pump after purging of } 7.5 \mathrm{~L} \text {. } \\
\text { Pump intake positioned at } 95 \mathrm{ft} .\end{array}$ \\
\hline 10/1/09 & $10: 50$ & MW12S & $43-53$ & BAMW12S-dry-Sep09 & MW & - & - & Well was dry. \\
\hline 10/1/09 & $11: 44$ & MW6S & $90.5-100.5$ & BAMW6S-W-28683 & MW & 2597 & 10/2/09 & $\begin{array}{l}\text { Depth to water }=88.85 \mathrm{ft} \text {. Depth of } 2 \text {-in. } \\
\text { well }=100.5 \mathrm{ft} \text {. Sample collected by using } \\
\text { low-flow bladder pump after purging of } \\
11 \mathrm{~L} \text {. Pump intake positioned at } 95.50 \mathrm{ft} .\end{array}$ \\
\hline
\end{tabular}


TABLE A.1 (Cont.)

\begin{tabular}{|c|c|c|c|c|c|c|c|c|}
\hline $\begin{array}{l}\text { Sample } \\
\text { Date }\end{array}$ & Time & $\begin{array}{l}\text { Sample } \\
\text { Location }\end{array}$ & $\begin{array}{l}\text { Depth } \\
\text { (ft BGL) }\end{array}$ & Sample & $\begin{array}{l}\text { Sample } \\
\text { Type }^{a}\end{array}$ & $\begin{array}{l}\text { Chain of } \\
\text { Custody }\end{array}$ & $\begin{array}{l}\text { Shipping } \\
\text { Date }\end{array}$ & Sample Description \\
\hline 10/1/09 & $12: 44$ & MW6D & $105-115$ & BAMW6D-W-28684 & MW & 2597 & 10/2/09 & $\begin{array}{l}\text { Depth to water }=91.92 \mathrm{ft} \text {. Depth of } 2 \text {-in. } \\
\text { well }=115 \mathrm{ft} \text {. Sample collected by using } \\
\text { low-flow bladder pump after purging of } \\
6 \mathrm{~L} \text {. Pump intake positioned at } 110 \mathrm{ft} \text {. }\end{array}$ \\
\hline 10/1/09 & $12: 56$ & MW12D & $115-125$ & BAMW12D-W-28695 & MW & 2597 & 10/2/09 & $\begin{array}{l}\text { Depth to water }=96.9 \mathrm{ft} \text {. Depth of } 2 \text {-in. well }= \\
125 \mathrm{ft} \text {. Sample collected by using low-flow } \\
\text { bladder pump after purging of } 7 \mathrm{~L} \text {. Pump } \\
\text { intake positioned at } 120 \mathrm{ft} \text {. }\end{array}$ \\
\hline 10/1/09 & $14: 38$ & MW11M & $90-100$ & BAMW11M-W-28691 & MW & 2597 & 10/2/09 & $\begin{array}{l}\text { Depth to water }=80.45 \mathrm{ft} \text {. Depth of } 2 \text {-in. } \\
\text { well }=100 \mathrm{ft} \text {. Sample collected by using } \\
\text { low-flow bladder pump after purging of } \\
13.5 \mathrm{~L} \text {. Pump intake positioned at } 95 \mathrm{ft} \text {. }\end{array}$ \\
\hline 10/1/09 & 14:46 & MW14S & $108-118$ & BAMW14S-W-28698 & MW & 2597 & 10/2/09 & $\begin{array}{l}\text { Depth to water }=101.43 \mathrm{ft} \text {. Depth of } 2 \text {-in. } \\
\text { well }=118 \mathrm{ft} . \text { Sample collected by using } \\
\text { low-flow bladder pump after purging of } \\
7 \mathrm{~L} \text {. Pump intake positioned at } 113 \mathrm{ft} .\end{array}$ \\
\hline 10/1/09 & $15: 45$ & MW11D & $125-135$ & BAMW11D-W-28692 & MW & 2597 & 10/2/09 & $\begin{array}{l}\text { Depth to water }=104.95 \mathrm{ft} \text {. Depth of } 2 \text {-in. } \\
\text { well }=135 \mathrm{ft} \text {. Sample collected by using } \\
\text { low-flow bladder pump after purging of } \\
5.5 \mathrm{~L} \text {. Pump intake positioned at } 130 \mathrm{ft} \text {. }\end{array}$ \\
\hline 10/1/09 & $15: 48$ & MW14D & $123-133$ & BAMW14D-W-28699 & MW & 2597 & 10/2/09 & $\begin{array}{l}\text { Depth to water }=101.48 \mathrm{ft} \text {. Depth of } 2 \text {-in. } \\
\text { well }=133 \mathrm{ft} \text {. Sample collected by using } \\
\text { low-flow bladder pump after purging of } \\
6 \mathrm{~L} \text {. Pump intake positioned at } 128 \mathrm{ft} \text {. }\end{array}$ \\
\hline 10/1/09 & 16:52 & MW11S & $40-50$ & BAMW11S-W-28690 & MW & 2597 & 10/2/09 & $\begin{array}{l}\text { Depth to water }=29.5 \mathrm{ft} \text {. Depth of } 1 \mathrm{in} \text {. well }= \\
50 \mathrm{ft} \text {. Sample collected by using low-flow } \\
\text { bladder pump after purging of } 2 \text { L. Pump } \\
\text { intake positioned at } 45 \mathrm{ft} \text {. }\end{array}$ \\
\hline 10/1/09 & $17: 30$ & $\mathrm{QC}$ & - & BAQCTB-W-28714 & TB & 2597 & 10/2/09 & $\begin{array}{l}\text { Trip blank sent to the AGEM Laboratory for } \\
\text { organic analysis with water samples listed } \\
\text { on COC } 2597 \text {. }\end{array}$ \\
\hline $12 / 14 / 09$ & $15: 50$ & PWS2 & 155 & BAPWS2-W-28715 & PW & 2672 & 12/15/09 & $\begin{array}{l}\text { Well last used the day prior to sampling (on } \\
\text { December 13). Allowed well to pump for } \\
10 \text { min, purging approximately } 400 \text { gal, } \\
\text { and then sampled. }\end{array}$ \\
\hline $12 / 14 / 09$ & $15: 44$ & PWS3 & 160 & BAPWS3-W-28716 & PW & 2672 & $12 / 15 / 09$ & $\begin{array}{l}\text { Well used the morning of sampling to fill the } \\
\text { water tower. Allowed well to pump for } \\
5 \text { min, then sampled. }\end{array}$ \\
\hline
\end{tabular}


TABLE A.1 (Cont.)

\begin{tabular}{|c|c|c|c|c|c|c|c|c|}
\hline $\begin{array}{l}\text { Sample } \\
\text { Date }\end{array}$ & Time & $\begin{array}{l}\text { Sample } \\
\text { Location }\end{array}$ & $\begin{array}{c}\text { Depth } \\
\text { (ft BGL) }\end{array}$ & Sample & $\begin{array}{c}\text { Sample } \\
\text { Type }^{a}\end{array}$ & $\begin{array}{l}\text { Chain of } \\
\text { Custody }\end{array}$ & $\begin{array}{l}\text { Shipping } \\
\text { Date }\end{array}$ & Sample Description \\
\hline $12 / 14 / 09$ & $16: 00$ & $\mathrm{QC}$ & - & BAQCTB-W-28717 & TB & 2672 & 12/15/09 & $\begin{array}{l}\text { Trip blank sent to the AGEM Laboratory for } \\
\text { organic analysis with water samples listed } \\
\text { on COC } 2672 \text {. }\end{array}$ \\
\hline
\end{tabular}

a Sample types: DW, domestic well; MW, monitoring well; PW, public water supply well; RI, rinsate; TB, trip blank. 
TABLE A.2 Field measurements for groundwater samples collected at Barnes, July 2006 to December 2009.

\begin{tabular}{|c|c|c|c|c|c|c|c|}
\hline Well & $\begin{array}{l}\text { Screen } \\
\text { Interval } \\
\text { (ft BGL) }\end{array}$ & $\begin{array}{l}\text { Sample } \\
\text { Date }\end{array}$ & $\begin{array}{c}\text { Temperature } \\
\left({ }^{\circ} \mathrm{C}\right)\end{array}$ & $\mathrm{pH}$ & $\begin{array}{c}\text { Conductivity } \\
(\mu \mathrm{S} / \mathrm{cm})\end{array}$ & $\begin{array}{l}\text { Dissolved } \\
\text { Oxygen } \\
\text { (mg/L) }\end{array}$ & $\begin{array}{r}\text { Reduc } \\
\text { Poten } \\
(\mathrm{mV}\end{array}$ \\
\hline \multicolumn{8}{|c|}{ Previously existing KDHE monitoring wells } \\
\hline \multirow[t]{9}{*}{ MW1S } & $13.3-23.3$ & $7 / 19 / 06^{a}$ & - & - & - & - & - \\
\hline & & $4 / 4 / 07^{a}$ & - & - & - & - & - \\
\hline & & $11 / 18 / 07^{a}$ & - & _- & _- & - & _- \\
\hline & & $3 / 4 / 08^{a}$ & - & - & - & - & - \\
\hline & & $7 / 9 / 08^{a}$ & - & - & - & - & - \\
\hline & & $10 / 22 / 08^{a}$ & - & - & - & - & - \\
\hline & & $3 / 4 / 09^{a}$ & - & - & - & - & - \\
\hline & & $6 / 17 / 09^{a}$ & - & - & - & - & - \\
\hline & & $9 / 30 / 09^{a}$ & - & - & - & - & - \\
\hline \multirow{9}{*}{ MW1D } & $139.85-159.4$ & $7 / 19 / 06$ & 22.8 & 7.15 & 945 & - & _- \\
\hline & & $4 / 4 / 07$ & 15.7 & 6.30 & 855 & - & - \\
\hline & & $11 / 18 / 07$ & 12.7 & 7.62 & 712 & - & - \\
\hline & & $3 / 4 / 08$ & 5.5 & 7.22 & 1167 & 11.6 & 244 \\
\hline & & 7/9/08 & 18.1 & 7.05 & 992 & 16.2 & 98 \\
\hline & & $10 / 22 / 08$ & 12.6 & 7.07 & 937 & 8.95 & 108 \\
\hline & & $3 / 4 / 09$ & 13.8 & 7.07 & 962 & 8.94 & 253 \\
\hline & & $6 / 17 / 09$ & 23.3 & 7.07 & 1021 & 5.43 & 106 \\
\hline & & 9/30/09 & 16.3 & 6.87 & 1007 & 6.74 & 268 \\
\hline \multirow[t]{9}{*}{ MW2D } & $133.26-152.93$ & $7 / 19 / 06$ & 24.7 & 7.72 & 946 & - & - \\
\hline & & $4 / 4 / 07$ & 15.1 & 6.32 & 887 & - & - \\
\hline & & $11 / 18 / 07$ & 12.1 & 6.96 & 1448 & - & - \\
\hline & & $3 / 7 / 08$ & 6.5 & 7.22 & 1198 & 4.61 & 197 \\
\hline & & $7 / 10 / 08$ & 18.4 & 6.91 & 1163 & 5.03 & 155 \\
\hline & & $10 / 22 / 08$ & 11.6 & 7.07 & 931 & 6.19 & 132 \\
\hline & & $3 / 4 / 09$ & 14.5 & 7.06 & 1126 & 5.60 & 243 \\
\hline & & 6/18/09 & 18.7 & 6.97 & 1235 & 3.55 & 116 \\
\hline & & 9/30/09 & 17.0 & 6.15 & 1196 & 3.44 & 25 \\
\hline \multirow[t]{9}{*}{ MW3D } & $133.02-152.73$ & $7 / 19 / 06$ & 23.0 & 7.06 & 976 & - & - \\
\hline & & $4 / 4 / 07$ & 15.6 & 6.37 & 989 & - & - \\
\hline & & $11 / 19 / 07$ & 10.5 & 7.16 & 1093 & - & - \\
\hline & & $3 / 7 / 08$ & 8.2 & 7.09 & 1195 & 5.34 & 255 \\
\hline & & $7 / 10 / 08$ & 19.8 & 6.99 & 1177 & 13.8 & 110 \\
\hline & & $10 / 22 / 08$ & 13.5 & 7.01 & 1238 & 4.46 & 84 \\
\hline & & $3 / 4 / 09$ & 12.8 & 7.08 & 1062 & 7.00 & 210 \\
\hline & & $6 / 17 / 09$ & 18.5 & 6.65 & 1038 & 5.90 & 110 \\
\hline & & 9/30/09 & 15.2 & 6.87 & 1057 & 5.96 & 209 \\
\hline \multirow[t]{9}{*}{ MW4D } & 98.38-118.22 & $7 / 20 / 06$ & 23.5 & 6.26 & 968 & - & - \\
\hline & & $4 / 6 / 07$ & 11.3 & 6.21 & 1018 & - & - \\
\hline & & $11 / 19 / 07$ & 15.7 & 6.98 & 1022 & - & - \\
\hline & & $3 / 9 / 08$ & 11.5 & 7.14 & 859 & 6.57 & 201 \\
\hline & & $7 / 12 / 08$ & 14.4 & 6.94 & 1001 & 6.77 & 149 \\
\hline & & $10 / 23 / 08$ & 13.0 & 7.02 & 973 & 5.56 & 94 \\
\hline & & $3 / 5 / 09$ & 15.9 & 7.61 & 1402 & 4.04 & 17 \\
\hline & & 6/18/09 & 18.5 & 7.03 & 975 & 5.72 & 127 \\
\hline & & 9/30/09 & 17.3 & 6.85 & 925 & 7.85 & 150 \\
\hline
\end{tabular}


TABLE A.2 (Cont.)

\begin{tabular}{|c|c|c|c|c|c|c|c|}
\hline Well & $\begin{array}{l}\text { Screen } \\
\text { Interval } \\
\text { (ft BGL) }\end{array}$ & $\begin{array}{l}\text { Sample } \\
\text { Date }\end{array}$ & $\begin{array}{c}\text { Temperature } \\
\left({ }^{\circ} \mathrm{C}\right)\end{array}$ & $\mathrm{pH}$ & $\begin{array}{l}\text { Conductivity } \\
(\mu \mathrm{S} / \mathrm{cm})\end{array}$ & $\begin{array}{c}\text { Dissolved } \\
\text { Oxygen } \\
(\mathrm{mg} / \mathrm{L})\end{array}$ & $\begin{array}{c}\text { Reduction } \\
\text { Potential } \\
(\mathrm{mV})\end{array}$ \\
\hline \multicolumn{8}{|c|}{ CCC/USDA wells installed during 2006-2007 investigation } \\
\hline \multirow[t]{8}{*}{ MW5 } & $110-120$ & $4 / 6 / 07$ & 13.9 & 6.17 & 1705 & - & - \\
\hline & & $11 / 19 / 07$ & 15.2 & 6.74 & 3070 & - & - \\
\hline & & $3 / 8 / 08$ & 9.9 & 6.76 & 2770 & 0.66 & 123 \\
\hline & & 7/11/08 & 18.8 & 6.66 & 2930 & 1.32 & 37 \\
\hline & & $10 / 23 / 08$ & 12.8 & 6.78 & 2384 & 0.67 & 20 \\
\hline & & 3/5/09 & 15.9 & 6.86 & 2146 & 2.36 & 56 \\
\hline & & 6/19/09 & 16.4 & 6.71 & 2292 & 1.01 & 45 \\
\hline & & 9/30/09 & 16.1 & 6.66 & 1780 & 3.08 & 72 \\
\hline \multirow[t]{8}{*}{ MW6S } & $90.5-100.5$ & $4 / 4 / 07^{a}$ & - & - & - & - & - \\
\hline & & $11 / 19 / 07$ & 12.0 & 7.60 & 723 & - & - \\
\hline & & $3 / 8 / 08$ & 4.7 & 7.77 & 673 & 6.72 & 272 \\
\hline & & $7 / 11 / 08$ & 28.2 & 7.61 & 753 & 9.85 & 92 \\
\hline & & $10 / 23 / 08$ & 11.9 & 11.17 & 582 & 5.12 & 91 \\
\hline & & 3/5/09 & 13.9 & 7.88 & 603 & 5.23 & 18 \\
\hline & & 6/18/09 & 19.5 & 7.70 & 698 & 4.52 & 27 \\
\hline & & 10/1/09 & 14.6 & 6.30 & 618 & 5.76 & 88 \\
\hline \multirow[t]{8}{*}{ MW6D } & $105-115$ & $4 / 5 / 07$ & 6.2 & 6.11 & 936 & - & - \\
\hline & & $11 / 19 / 07$ & 13.6 & 7.00 & 1103 & - & - \\
\hline & & $3 / 8 / 08$ & 9.1 & 7.15 & 908 & 5.56 & 241 \\
\hline & & 7/11/08 & 19.8 & 7.05 & 999 & 12.8 & 100 \\
\hline & & $10 / 23 / 08$ & 12.0 & 7.18 & 957 & 6.27 & 128 \\
\hline & & 3/5/09 & 13.4 & 7.22 & 903 & 3.07 & 21 \\
\hline & & 6/18/09 & 19.0 & 6.86 & 992 & 4.44 & 114 \\
\hline & & 10/1/09 & 16.0 & 6.41 & 910 & 4.18 & 98 \\
\hline \multirow[t]{8}{*}{ MW7 } & $116-126$ & 4/6/07 & 14.1 & 6.30 & 1051 & - & - \\
\hline & & 11/19/07 & 14.6 & 7.16 & 890 & - & - \\
\hline & & 3/9/08 & 13.1 & 7.10 & 1068 & 4.24 & 186 \\
\hline & & $7 / 12 / 08$ & 14.4 & 6.95 & 1238 & 4.36 & 98 \\
\hline & & 10/23/08 & 12.7 & 7.16 & 1191 & 8.61 & 122 \\
\hline & & $3 / 5 / 09$ & 15.3 & 7.11 & 1141 & 9.93 & 126 \\
\hline & & 6/19/09 & 16.3 & 7.05 & 1174 & 4.32 & 48 \\
\hline & & 9/30/09 & 16.2 & 6.86 & 1132 & 8.24 & 216 \\
\hline \multirow[t]{8}{*}{ MW8 } & $110-120$ & 4/6/07 & 12.1 & 6.23 & 974 & - & - \\
\hline & & $11 / 19 / 07$ & 14.6 & 7.03 & 909 & - & - \\
\hline & & 3/10/08 & 13.1 & 7.09 & 961 & 6.71 & 182 \\
\hline & & $7 / 11 / 08$ & 18.6 & 6.38 & 1049 & 6.19 & 152 \\
\hline & & $10 / 23 / 08$ & 12.9 & 7.06 & 948 & 8.74 & 97 \\
\hline & & 3/5/09 & 16.2 & 7.12 & 985 & 9.43 & 165 \\
\hline & & 6/19/09 & 18.0 & 7.07 & 972 & 6.65 & 102 \\
\hline & & 9/30/09 & 16.7 & 6.15 & 889 & 6.22 & 33 \\
\hline
\end{tabular}


TABLE A.2 (Cont.)

\begin{tabular}{|c|c|c|c|c|c|c|c|}
\hline Well & $\begin{array}{l}\text { Screen } \\
\text { Interval } \\
\text { (ft BGL) }\end{array}$ & $\begin{array}{l}\text { Sample } \\
\text { Date }\end{array}$ & $\begin{array}{c}\text { Temperature } \\
\left({ }^{\circ} \mathrm{C}\right)\end{array}$ & $\mathrm{pH}$ & $\begin{array}{l}\text { Conductivity } \\
(\mu \mathrm{S} / \mathrm{cm})\end{array}$ & $\begin{array}{c}\text { Dissolved } \\
\text { Oxygen } \\
\text { (mg/L) }\end{array}$ & $\begin{array}{r}\text { Reduct } \\
\text { Potent } \\
(\mathrm{mV})\end{array}$ \\
\hline \multicolumn{8}{|c|}{ CCC/USDA wells installed during 2006-2007 investigation (cont.) } \\
\hline \multirow[t]{8}{*}{ MW9 } & $100-110$ & $4 / 5 / 07$ & 12.9 & 6.20 & 976 & - & - \\
\hline & & $11 / 19 / 07$ & 16.5 & 7.21 & 1066 & - & - \\
\hline & & $3 / 9 / 08$ & 11.2 & 7.07 & 928 & 5.80 & 239 \\
\hline & & $7 / 11 / 08$ & 17.7 & 6.58 & 1010 & 5.63 & 189 \\
\hline & & $10 / 24 / 08$ & 13.0 & 7.06 & 888 & 5.42 & 79 \\
\hline & & $3 / 5 / 09$ & 16.2 & 7.10 & 939 & 8.40 & 173 \\
\hline & & $6 / 17 / 09$ & 15.9 & 6.87 & 907 & 5.62 & 146 \\
\hline & & 9/29/09 & 13.9 & 6.79 & 871 & 7.84 & 135 \\
\hline \multirow[t]{8}{*}{ MW10S } & $93-103$ & $4 / 6 / 07$ & 13.2 & 6.36 & 1004 & - & - \\
\hline & & $11 / 19 / 07$ & 14.5 & 7.22 & 942 & - & - \\
\hline & & 3/10/08 & 12.7 & 7.08 & 912 & 5.18 & 176 \\
\hline & & $7 / 11 / 08$ & 17.3 & 6.91 & 975 & 12.8 & 119 \\
\hline & & $10 / 23 / 08$ & 13.4 & 7.08 & 913 & 5.39 & 78 \\
\hline & & $3 / 5 / 09$ & 15.3 & 7.25 & 895 & 2.66 & 13 \\
\hline & & $6 / 19 / 09$ & 16.0 & 7.12 & 925 & 5.44 & 104 \\
\hline & & 9/30/09 & 15.8 & 6.58 & 829 & 4.63 & 31 \\
\hline \multirow[t]{8}{*}{ MW10D } & $115-125$ & $4 / 6 / 07$ & 12.1 & 6.21 & 992 & - & - \\
\hline & & $11 / 19 / 07$ & 14.5 & 7.42 & 1175 & - & - \\
\hline & & $3 / 9 / 08$ & 13.7 & 7.01 & 1024 & 5.07 & 236 \\
\hline & & $7 / 11 / 08$ & 17.4 & 6.78 & 1090 & 12.6 & 117 \\
\hline & & $10 / 23 / 08$ & 13.5 & 7.01 & 1000 & 5.00 & 93 \\
\hline & & $3 / 5 / 09$ & 15.9 & 7.20 & 969 & 4.37 & 12 \\
\hline & & $6 / 19 / 09$ & 16.9 & 7.08 & 1035 & 5.70 & 109 \\
\hline & & 9/30/09 & 15.8 & 6.62 & 922 & 5.48 & 32 \\
\hline \multirow[t]{8}{*}{ MW11S } & $40-50$ & $4 / 4 / 07$ & 12.8 & 6.14 & 1027 & - & - \\
\hline & & $11 / 19 / 07$ & 11.2 & 7.15 & 1174 & - & - \\
\hline & & $3 / 5 / 08$ & 9.4 & 6.81 & 1122 & 2.26 & 241 \\
\hline & & $7 / 10 / 08$ & 19.5 & 6.47 & 1224 & 1.86 & 166 \\
\hline & & $10 / 23 / 08$ & 10.2 & 6.99 & 1085 & 5.80 & 146 \\
\hline & & $3 / 4 / 09$ & 14.5 & 7.11 & 1186 & 4.32 & 37 \\
\hline & & 6/19/09 & 15.0 & 6.81 & 1159 & 3.11 & 173 \\
\hline & & 10/1/09 & 15.9 & 6.67 & 1114 & 2.16 & 203 \\
\hline \multirow[t]{8}{*}{ MW11M } & $90-100$ & $4 / 5 / 07$ & 7.5 & 7.60 & 1097 & - & - \\
\hline & & $11 / 19 / 07$ & 11.9 & 7.17 & 1144 & - & - \\
\hline & & $3 / 6 / 08$ & 10.8 & 7.06 & 997 & 2.65 & 254 \\
\hline & & $7 / 10 / 08$ & 31.9 & 7.08 & 1124 & 3.88 & 149 \\
\hline & & $10 / 23 / 08$ & 12.4 & 7.06 & 962 & 3.19 & 116 \\
\hline & & $3 / 4 / 09$ & 13.6 & 7.33 & 910 & 4.90 & 28 \\
\hline & & 6/19/09 & 14.7 & 6.92 & 973 & 4.84 & 185 \\
\hline & & $10 / 1 / 09$ & 14.5 & 6.85 & 919 & 6.66 & 153 \\
\hline
\end{tabular}


TABLE A.2 (Cont.)

\begin{tabular}{|c|c|c|c|c|c|c|c|}
\hline Well & $\begin{array}{l}\text { Screen } \\
\text { Interval } \\
\text { (ft BGL) }\end{array}$ & $\begin{array}{l}\text { Sample } \\
\text { Date }\end{array}$ & $\begin{array}{c}\text { Temperature } \\
\left({ }^{\circ} \mathrm{C}\right)\end{array}$ & $\mathrm{pH}$ & $\begin{array}{c}\text { Conductivity } \\
(\mu \mathrm{S} / \mathrm{cm})\end{array}$ & $\begin{array}{l}\text { Dissolved } \\
\text { Oxygen } \\
\text { (mg/L) }\end{array}$ & $\begin{array}{r}\text { Reduc } \\
\text { Poter } \\
\text { (m) }\end{array}$ \\
\hline \multicolumn{8}{|c|}{ CCC/USDA wells installed during 2006-2007 investigation (cont.) } \\
\hline \multirow[t]{8}{*}{ MW11D } & $125-135$ & $4 / 4 / 07$ & 13.8 & 6.18 & 990 & - & - \\
\hline & & $11 / 19 / 07$ & 13.1 & 7.22 & 987 & _- & - \\
\hline & & $3 / 5 / 08$ & 6.0 & 7.06 & 872 & 6.85 & 252 \\
\hline & & $7 / 10 / 08$ & 17.5 & 6.25 & 957 & 7.14 & 177 \\
\hline & & $10 / 23 / 08$ & 12.3 & 7.11 & 863 & 8.71 & 123 \\
\hline & & $3 / 4 / 09$ & 14.3 & 7.23 & 848 & 4.47 & 27 \\
\hline & & 6/19/09 & 17.4 & 6.96 & 885 & 5.92 & 131 \\
\hline & & $10 / 1 / 09$ & 14.7 & 6.85 & 854 & 6.91 & 154 \\
\hline \multirow{8}{*}{ MW12S } & $43-53$ & $4 / 5 / 07^{a}$ & - & - & - & - & - \\
\hline & & $11 / 19 / 07^{a}$ & - & - & - & - & - \\
\hline & & $3 / 10 / 08^{a}$ & - & - & - & - & - \\
\hline & & $7 / 10 / 08^{a}$ & - & - & - & - & - \\
\hline & & $10 / 22 / 08^{a}$ & - & - & - & - & - \\
\hline & & $3 / 4 / 09^{a}$ & - & - & - & - & - \\
\hline & & $6 / 19 / 09$ & 20.5 & 7.00 & 1436 & - & - \\
\hline & & $10 / 1 / 09^{a}$ & - & - & - & - & - \\
\hline \multirow{8}{*}{ MW12M } & $90-100$ & $4 / 5 / 07$ & 12.6 & 6.42 & 867 & - & - \\
\hline & & $11 / 19 / 07$ & 14.9 & 7.13 & 835 & - & - \\
\hline & & $3 / 10 / 08$ & 12.6 & 7.13 & 665 & 1.81 & 212 \\
\hline & & $7 / 10 / 08$ & 16.9 & 7.09 & 878 & 8.17 & 87 \\
\hline & & $10 / 22 / 08$ & 12.2 & 7.20 & 785 & 8.93 & 126 \\
\hline & & $3 / 4 / 09$ & 14.1 & 7.24 & 851 & 2.15 & 20 \\
\hline & & $6 / 19 / 09$ & 17.0 & 6.99 & 856 & 2.34 & 112 \\
\hline & & $10 / 1 / 09$ & 14.4 & 6.81 & 840 & 3.41 & 52 \\
\hline \multirow[t]{8}{*}{ MW12D } & $115-125$ & $4 / 5 / 07$ & 14.0 & 6.36 & 930 & - & - \\
\hline & & $11 / 18 / 07$ & 15.6 & 6.95 & 571 & - & - \\
\hline & & $3 / 9 / 08$ & 8.8 & 7.13 & 881 & 5.25 & 237 \\
\hline & & $7 / 11 / 08$ & 19.9 & 6.01 & 987 & 4.72 & 197 \\
\hline & & $10 / 22 / 08$ & 12.3 & 7.09 & 873 & 7.96 & 136 \\
\hline & & $3 / 4 / 09$ & 14.4 & 7.25 & 923 & 4.06 & 21 \\
\hline & & $6 / 19 / 09$ & 16.4 & 6.96 & 895 & 5.08 & 150 \\
\hline & & $10 / 1 / 09$ & 15.8 & 6.85 & 869 & 6.74 & 154 \\
\hline \multirow[t]{8}{*}{ MW13S } & $112-122$ & $4 / 5 / 07$ & 9.8 & 6.42 & 946 & - & - \\
\hline & & $11 / 19 / 07$ & 16.5 & 7.21 & 893 & - & - \\
\hline & & $3 / 10 / 08$ & 12.2 & 7.13 & 810 & 6.21 & 199 \\
\hline & & $7 / 9 / 08$ & 17.4 & 6.99 & 875 & 7.72 & 116 \\
\hline & & $10 / 22 / 08$ & 13.5 & 7.08 & 793 & 5.08 & 100 \\
\hline & & $3 / 4 / 09$ & 13.8 & 7.23 & 818 & 4.39 & 29 \\
\hline & & $6 / 18 / 09$ & 17.6 & 7.04 & 803 & 6.12 & 104 \\
\hline & & $9 / 30 / 09$ & 15.4 & 5.74 & 721 & 6.06 & 177 \\
\hline
\end{tabular}


TABLE A.2 (Cont.)

\begin{tabular}{|c|c|c|c|c|c|c|c|}
\hline Well & $\begin{array}{l}\text { Screen } \\
\text { Interval } \\
\text { (ft BGL) }\end{array}$ & $\begin{array}{l}\text { Sample } \\
\text { Date }\end{array}$ & $\begin{array}{c}\text { Temperature } \\
\left({ }^{\circ} \mathrm{C}\right)\end{array}$ & $\mathrm{pH}$ & $\begin{array}{c}\text { Conductivity } \\
(\mu \mathrm{S} / \mathrm{cm})\end{array}$ & $\begin{array}{l}\text { Dissolved } \\
\text { Oxygen } \\
\text { (mg/L) }\end{array}$ & $\begin{array}{r}\text { Reduct } \\
\text { Potent } \\
(\mathrm{mV})\end{array}$ \\
\hline \multicolumn{8}{|c|}{ CCC/USDA wells installed during 2006-2007 investigation (cont.) } \\
\hline \multirow[t]{8}{*}{ MW13D } & $127-137$ & $4 / 5 / 07$ & 14.9 & 6.25 & 397 & - & - \\
\hline & & $11 / 19 / 07$ & 17.0 & 7.00 & 763 & - & - \\
\hline & & $3 / 9 / 08$ & 13.1 & 7.09 & 758 & 5.95 & 213 \\
\hline & & $7 / 9 / 08$ & 18.6 & 7.07 & 848 & 18.1 & 57 \\
\hline & & $10 / 22 / 08$ & 13.3 & 7.06 & 824 & 5.28 & 98 \\
\hline & & $3 / 4 / 09$ & 14.5 & 7.19 & 833 & 4.01 & 25 \\
\hline & & $6 / 18 / 09$ & 17.5 & 6.93 & 828 & 5.60 & 117 \\
\hline & & $9 / 30 / 09$ & 17.4 & 5.99 & 706 & 5.60 & 142 \\
\hline \multirow[t]{8}{*}{ MW14S } & $108-118$ & $4 / 4 / 07$ & 13.4 & 6.50 & 704 & - & - \\
\hline & & $11 / 18 / 07$ & 12.9 & 7.26 & 966 & - & - \\
\hline & & $3 / 8 / 08$ & 13.2 & 7.20 & 729 & 6.59 & 208 \\
\hline & & 7/10/08 & 17.4 & 7.16 & 775 & 16.4 & 87 \\
\hline & & $10 / 22 / 08$ & 13.2 & 7.11 & 716 & 5.81 & 90 \\
\hline & & $3 / 4 / 09$ & 13.8 & 7.15 & 736 & 8.96 & 268 \\
\hline & & $6 / 18 / 09$ & 17.5 & 7.01 & 742 & 5.18 & 97 \\
\hline & & $10 / 1 / 09$ & 16.0 & 6.25 & 663 & 5.78 & 99 \\
\hline \multirow[t]{8}{*}{ MW14D } & $123-133$ & $4 / 4 / 07$ & 14.7 & 6.34 & 932 & - & - \\
\hline & & $11 / 18 / 07$ & 13.2 & 7.47 & 739 & - & - \\
\hline & & $3 / 8 / 08$ & 12.0 & 7.06 & 1424 & 1.95 & 282 \\
\hline & & 7/10/08 & 17.7 & 7.07 & 1459 & 14.5 & 86 \\
\hline & & $10 / 22 / 08$ & 13.0 & 7.00 & 1212 & 1.41 & 79 \\
\hline & & $3 / 5 / 09$ & 13.6 & 7.06 & 1339 & 2.15 & 69 \\
\hline & & 6/18/09 & 19.8 & 7.04 & 1523 & 1.99 & 46 \\
\hline & & $10 / 1 / 09$ & 15.5 & 6.21 & 1154 & 1.59 & 90 \\
\hline \multirow[t]{8}{*}{ MW15S } & $88-98$ & $4 / 4 / 07$ & 13.1 & 8.03 & 854 & - & - \\
\hline & & $11 / 18 / 07$ & 13.9 & NR & 1883 & - & - \\
\hline & & 3/10/08 & 12.1 & 8.67 & 697 & 5.49 & 173 \\
\hline & & $7 / 12 / 08$ & 14.0 & 8.88 & 660 & 11.6 & 94 \\
\hline & & $10 / 23 / 08$ & 13.0 & 8.00 & 789 & 5.27 & 67 \\
\hline & & $3 / 5 / 09$ & 15.7 & 8.78 & 589 & 7.48 & 163 \\
\hline & & $6 / 17 / 09$ & 18.2 & 9.13 & 386 & 4.84 & 62 \\
\hline & & $9 / 29 / 09$ & 15.4 & 7.40 & 786 & 6.93 & 181 \\
\hline \multirow[t]{8}{*}{ MW15D } & $105-115$ & $4 / 4 / 07$ & 14.8 & 6.15 & 2980 & - & - \\
\hline & & $11 / 18 / 07$ & 13.1 & 6.85 & 2190 & - & - \\
\hline & & $3 / 8 / 08$ & 9.0 & 6.85 & 2912 & 0.57 & 131 \\
\hline & & $7 / 12 / 08$ & 14.1 & 6.80 & 3067 & 1.05 & 90 \\
\hline & & $10 / 24 / 08$ & 13.0 & 6.81 & 2876 & 0.34 & 27 \\
\hline & & $3 / 5 / 09$ & 15.8 & 6.82 & 2945 & 0.41 & -15 \\
\hline & & $6 / 17 / 09$ & 18.6 & 6.71 & 2887 & 0.61 & 51 \\
\hline & & $9 / 29 / 09$ & 15.6 & 6.53 & 2848 & 0.25 & 92 \\
\hline
\end{tabular}


TABLE A.2 (Cont.)

\begin{tabular}{|c|c|c|c|c|c|c|c|}
\hline Well & $\begin{array}{l}\text { Screen } \\
\text { Interval } \\
\text { (ft BGL) }\end{array}$ & $\begin{array}{l}\text { Sample } \\
\text { Date }\end{array}$ & $\begin{array}{c}\text { Temperature } \\
\left({ }^{\circ} \mathrm{C}\right)\end{array}$ & $\mathrm{pH}$ & $\begin{array}{c}\text { Conductivity } \\
(\mu \mathrm{S} / \mathrm{cm})\end{array}$ & $\begin{array}{c}\text { Dissolved } \\
\text { Oxygen } \\
\text { (mg/L) }\end{array}$ & $\begin{array}{c}\text { Reduction } \\
\text { Potential } \\
\text { (mV) }\end{array}$ \\
\hline \multicolumn{8}{|c|}{ CCC/USDA wells installed during 2006-2007 investigation (cont.) } \\
\hline \multirow[t]{8}{*}{ MW16S } & $76-86$ & $4 / 4 / 07$ & 12.8 & 6.35 & 1708 & - & - \\
\hline & & $11 / 19 / 07$ & 15.0 & 6.94 & 1616 & - & - \\
\hline & & $3 / 7 / 08$ & 7.3 & 6.96 & 1968 & 3.45 & 184 \\
\hline & & 7/11/08 & 18.8 & 6.71 & 2883 & 1.13 & 52 \\
\hline & & 10/23/08 & 11.6 & 7.01 & 1350 & 6.01 & 136 \\
\hline & & 3/5/09 & 16.3 & 7.19 & 1505 & 2.49 & 12 \\
\hline & & $6 / 18 / 09$ & 15.9 & 7.03 & 971 & 5.57 & 101 \\
\hline & & 9/29/09 & 14.3 & 6.76 & 963 & 7.50 & 123 \\
\hline \multirow[t]{8}{*}{ MW16D } & $90-100$ & $4 / 4 / 07$ & 14.1 & 6.17 & 2910 & - & - \\
\hline & & 11/19/07 & 12.5 & 6.78 & 2400 & - & - \\
\hline & & 3/7/08 & 7.0 & 6.86 & 2866 & 0.50 & 140 \\
\hline & & $7 / 11 / 08$ & 18.9 & 6.64 & 3134 & 0.41 & 32 \\
\hline & & 10/23/08 & 11.3 & 6.79 & 2791 & 0.45 & 37 \\
\hline & & 3/5/09 & 15.6 & 6.94 & 2926 & 0.27 & 14 \\
\hline & & 6/18/09 & 18.3 & 6.77 & 2867 & 0.30 & 46 \\
\hline & & 9/29/09 & 14.4 & 6.67 & 2583 & 0.64 & 17 \\
\hline \multirow[t]{8}{*}{ MW17 } & $120-130$ & $4 / 4 / 07$ & 16.0 & 6.44 & 861 & - & - \\
\hline & & $11 / 19 / 07$ & 8.3 & 7.15 & 610 & - & - \\
\hline & & 3/5/08 & 5.5 & 7.12 & 804 & 7.02 & 239 \\
\hline & & $7 / 9 / 08$ & 17.5 & 7.11 & 843 & 20.6 & 89 \\
\hline & & 10/22/08 & 13.1 & 7.10 & 777 & 8.35 & 110 \\
\hline & & $3 / 4 / 09$ & 14.1 & 7.12 & 823 & 8.47 & 258 \\
\hline & & $6 / 17 / 09$ & 18.4 & 7.01 & 825 & 5.65 & 103 \\
\hline & & 9/30/09 & 14.8 & 6.89 & 800 & 7.74 & 248 \\
\hline \multicolumn{8}{|c|}{ Private wells } \\
\hline \multirow[t]{10}{*}{ Oentrich } & 150 & 7/20/06 & - & - & - & - & - \\
\hline & & $8 / 2 / 06$ & - & - & - & - & - \\
\hline & & $4 / 5 / 07$ & - & - & - & - & - \\
\hline & & $11 / 19 / 07$ & 12.1 & 8.26 & 1830 & - & - \\
\hline & & $3 / 6 / 08$ & - & - & - & - & - \\
\hline & & 7/11/08 & - & - & - & - & - \\
\hline & & 10/23/08 & - & - & - & - & - \\
\hline & & 3/5/09 & - & - & - & - & - \\
\hline & & $6 / 18 / 09$ & 15.3 & 7.15 & 1270 & - & - \\
\hline & & 9/30/09 & 15.6 & 7.14 & 1275 & NR & NR \\
\hline \multirow[t]{2}{*}{ Sedivy } & 138 & 8/22/06 & - & - & - & - & - \\
\hline & & 9/13/06 & 22.5 & 6.57 & 739 & - & - \\
\hline
\end{tabular}

a Not sampled (well dry). 


\section{Appendix B:}

\section{Waste Characterization Data}




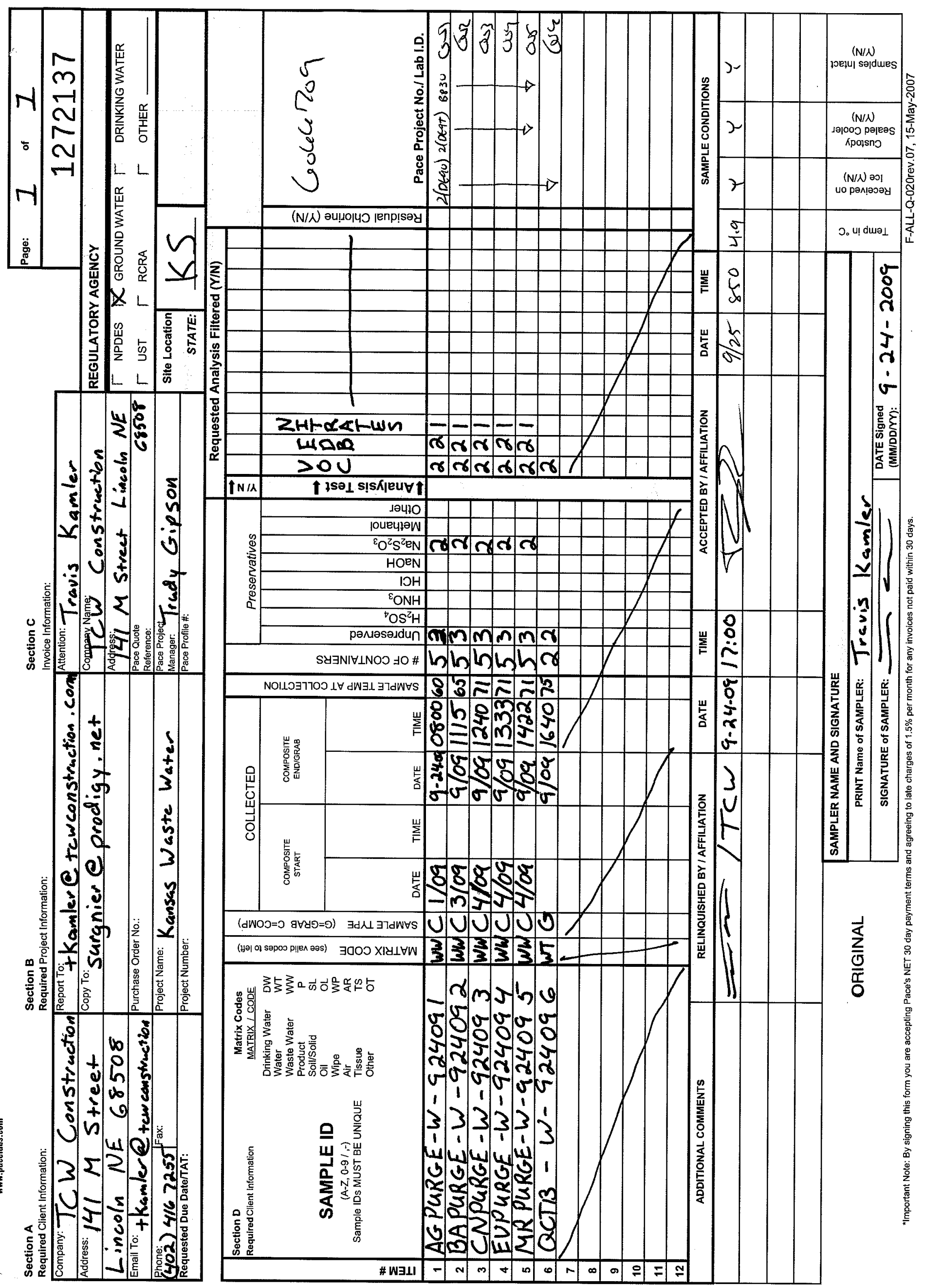




\section{Sample Condition Upon Receipt}

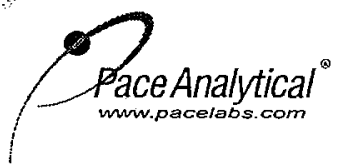

Client Name: tCW Project \# Cock709

Courier: $\square$ Fed Ex $\square$ UPS $\square$ USPS $\square$ Client $\square$ Commercial $\square$ pace Other Tracking \#: 555876829061

Custody Seal on Cooler/Box Present: $\succeq$ yes $\square$ no Seals intact: $\square$ yes $\square$ no

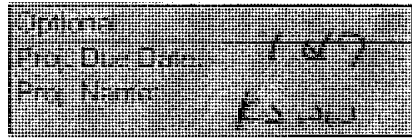

Packing Material: $\square$ Bubble Wrap $\square$ Bubble Bags $\square$ None $\square$ Other

\begin{tabular}{|c|c|c|c|}
\hline Thermometer Used & Type of Ice: Wet & Blue None & $\square$ Samples on ice, cooling process has begun \\
\hline Cooler Temperature & Biological Tissue i & is Frozen: Yes No & $\begin{array}{l}\text { Date and Initialsof person examining } \\
\text { contents: } 1 / 25\end{array}$ \\
\hline Temp should be above freezing to $6^{\circ} \mathrm{C}$ & & Comments: & \\
\hline Chain of Custody Present: & שres $\square$ No $\square \mathrm{N} / \mathrm{A}$ & 1. & \\
\hline Chain of Custody Filled Out: & Gres $\square$ No $\square \mathrm{N} / \mathrm{A}$ & 2. & \\
\hline Chain of Custody Relinquished: & GYes $\square$ No $\quad \square \mathrm{N} / \mathrm{A}$ & 3. & \\
\hline Sampler Name \& Signature on COC: & EYes $\square$ No $\square \mathrm{N} / \mathrm{A}$ & 4. & \\
\hline Samples Arrived within Hold Time: & 七res $\square$ No $\square \mathrm{N} / \mathrm{A}$ & 5. & \\
\hline Short Hold Time Analysis ( $<72 \mathrm{hr})$ : & $\square$ Yes $\square$ No $\square \mathrm{N} / \mathrm{A}$ & $\mathrm{NO}_{3}$ & \\
\hline Rush Turn Around Time Requested: & $\square$ Yes $\square^{\prime}$ No $\quad \square \mathrm{N} / \mathrm{A}$ & 7. & \\
\hline Sufficient Volume: & EYes $\square$ No $\square \mathrm{N} / \mathrm{A}$ & 8. & \\
\hline $\begin{array}{l}\text { Correct Containers Used: } \\
\text {-Pace Containers Used: }\end{array}$ & 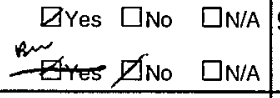 & 9. & \\
\hline Containers Intact: & $\square$ Yes $\square$ No $\quad \square \mathrm{N} / \mathrm{A}$ & 10. & \\
\hline Filtered volume received for Dissolved tests & $\square$ Yes $\square$ No $\quad \square \mathrm{N} / \mathrm{A}$ & 11. & \\
\hline $\begin{array}{l}\text { Sample Labels match COC: } \\
\text {-Includes date/time/ID/Analysis Matrix: } \\
\end{array}$ & 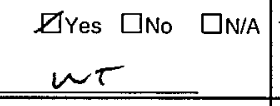 & $\begin{array}{l}12 . \\
\text { AU SAMPCES }\end{array}$ & COLEOTED a/24 SCCORDOWU TO \\
\hline $\begin{array}{l}\text { All containers needing preservation have been checked. } \\
\text { All containers needing preservation are found to be in } \\
\text { compliance with EPA recommendation. }\end{array}$ & $\begin{array}{lll}\square \text { Yes } & \square \text { No } & \square_{N / A} \\
\square \text { Yes } & \square \text { No } & \square_{N / A}\end{array}$ & 13. UABELS & \\
\hline exceptions: NOA, coliform, TOC, O\&G, WI-DRO (water) & $\forall$ Yres $\square$ No & $\begin{array}{l}\text { Initial when } \\
\text { completed }\end{array}$ & $\begin{array}{l}\text { Lot \# of added } \\
\text { preservative }\end{array}$ \\
\hline Samples checked for dechlorination: & पYes $\square$ No $\quad \square \mathrm{N} / \mathrm{A}$ & 14. & \\
\hline Headspace in VOA Vials $(>6 \mathrm{~mm})$ : & 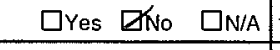 & 15. & \\
\hline $\begin{array}{l}\text { Trip Blank Present: } \\
\text { Trip Blank Custody Seals Present } \\
\text { Pace Trip Blank Lot \# (if purchased): }\end{array}$ & $\begin{array}{lll}\square^{\prime} \text { Yes } & \square \text { No } & \square \mathrm{N} / \mathrm{A} \\
\text {ZZTes } & \square \mathrm{No} & \square \mathrm{N} / \mathrm{A}\end{array}$ & 16. & \\
\hline
\end{tabular}

Pace Trip Blank Lot \# (if purchased):

Client Notification/Resolution: $\quad$ Copy COC to Client? $\quad \mathrm{Y} / \mathrm{N} \quad$ Field Data Required? $\mathrm{Y} / \mathrm{N}$

Person Contacted: Travis Kamler Date/Time: 9-25.09

comments/Resolution: Per cllent-aul samples collected on 9-24-09, ypt

Project Manager Review: $\quad$ Ap \& $9-28-09$

Date:

Note: Whenever there is a discrepancy affecting North Carolina compliance samples, a copy of this form will be sent to the North Carolina DEHNR Certification Office (i.e out of hold, incorrect preservative, out of temp, incorrect containers) 


\section{SAMPLE ACKNOWLEDGMENT}

Samples Submitted By: Client Project ID:

Client PO\#:
TCW Construction Inc

Kansas Waste Water

Credit Card

\author{
Pace Project Manager: \\ Pace Analytical Project ID: \\ Samples Received: \\ Estimated Completion:
}

Trudy Gipson

Phone 1(913)563-1405

trudy.gipson@pacelabs.com

6066709

September 25, 2009

October 07, 2009

\begin{tabular}{|c|c|c|c|c|}
\hline Customer Sample ID & $\begin{array}{l}\text { Pace Analytical } \\
\text { Lab ID }\end{array}$ & Matrix & $\begin{array}{l}\text { Date/Time } \\
\text { Collected }\end{array}$ & Method \\
\hline AGPURGE-W-924091 & 6066709001 & Water & 09/24/09 08:00 & $\begin{array}{l}300.0 \text { IC Anions } \\
504 \text { GCS EDB and DBCP } \\
8260 \mathrm{MSV}\end{array}$ \\
\hline BAPURGE-W-924092 & 6066709002 & Water & 09/24/09 11:15 & $\begin{array}{l}300.0 \text { IC Anions } \\
504 \text { GCS EDB and DBCP } \\
8260 \mathrm{MSV}\end{array}$ \\
\hline CNPURGE-W-924093 & 6066709003 & Water & 09/24/09 12:40 & $\begin{array}{l}\text { 300.0 IC Anions } \\
504 \text { GCS EDB and DBCP } \\
8260 \mathrm{MSV}\end{array}$ \\
\hline EUPURGE-W-924094 & 6066709004 & Water & 09/24/09 13:33 & $\begin{array}{l}300.0 \text { IC Anions } \\
504 \text { GCS EDB and DBCP } \\
8260 \mathrm{MSV}\end{array}$ \\
\hline MRPURGE-W-924095 & 6066709005 & Water & 09/24/09 14:22 & $\begin{array}{l}300.0 \text { IC Anions } \\
504 \text { GCS EDB and DBCP } \\
8260 \mathrm{MSV}\end{array}$ \\
\hline QCTB-W-924096 & 6066709006 & Water & 09/24/09 16:40 & $8260 \mathrm{MSV}$ \\
\hline
\end{tabular}


October 13, 2009

Mr. Travis Kamler

TCW Construction Inc

$141 \mathrm{M}$ Street

Lincoln, NE 68508

RE: Project: Kansas Waste Water

Pace Project No.: 6066709

Dear Mr. Kamler:

Enclosed are the analytical results for sample(s) received by the laboratory on September 25, 2009. The results relate only to the samples included in this report. Results reported herein conform to the most current NELAC standards, where applicable, unless otherwise narrated in the body of the report.

If you have any questions concerning this report, please feel free to contact me.

Sincerely,

$$
\text { sudy sigoon }
$$

Trudy Gipson

trudy.gipson@pacelabs.com

Project Manager

Enclosures

cc: Mr. David Surgnier 


\section{CERTIFICATIONS}

Project: Kansas Waste Water

Pace Project No.: 6066709

Kansas Certification IDs

Washington Certification \#: C2069

Utah Certification \#: 9135995665

Texas Certification \#: T104704407-08-TX

Oregon Certification \#: KS200001

Oklahoma Certification \#: 9205/9935

Nevada Certification \#: KS000212008A
Louisiana Certification \#: 03055

Kansas/NELAP Certification \#: E-10116

lowa Certification \#: 118

Illinois Certification \#: 001191

Arkansas Certification \#: 05-008-0

A2LA Certification \#: 2456.01

This report shall not be reproduced, except in full, without the written consent of Pace Analytical Services, Inc. 
SAMPLE SUMMARY

Project: Kansas Waste Water

Pace Project No.: 6066709

\begin{tabular}{|c|c|c|c|c|}
\hline Lab ID & Sample ID & Matrix & Date Collected & Date Received \\
\hline 6066709001 & AGPURGE-W-924091 & Water & 09/24/09 08:00 & 09/25/09 08:50 \\
\hline 6066709002 & BAPURGE-W-924092 & Water & 09/24/09 11:15 & 09/25/09 08:50 \\
\hline 6066709003 & CNPURGE-W-924093 & Water & 09/24/09 12:40 & 09/25/09 08:50 \\
\hline 6066709004 & EUPURGE-W-924094 & Water & 09/24/09 13:33 & 09/25/09 08:50 \\
\hline 6066709005 & MRPURGE-W-924095 & Water & 09/24/09 14:22 & 09/25/09 08:50 \\
\hline 6066709006 & QCTB-W-924096 & Water & 09/24/09 16:40 & 09/25/09 08:50 \\
\hline
\end{tabular}




\section{SAMPLE ANALYTE COUNT}

Project: Kansas Waste Water

Pace Project No.: 6066709

\begin{tabular}{|c|c|c|c|c|}
\hline Lab ID & Sample ID & Method & Analysts & $\begin{array}{l}\text { Analytes } \\
\text { Reported }\end{array}$ \\
\hline \multirow[t]{3}{*}{6066709001} & AGPURGE-W-924091 & EPA 300.0 & RAB & 1 \\
\hline & & EPA 5030B/8260 & NPM & 70 \\
\hline & & EPA 504.1 & WAW & 1 \\
\hline \multirow[t]{3}{*}{6066709002} & BAPURGE-W-924092 & EPA 300.0 & RAB & 1 \\
\hline & & EPA 5030B/8260 & NPM & 70 \\
\hline & & EPA 504.1 & WAW & 1 \\
\hline \multirow[t]{3}{*}{6066709003} & CNPURGE-W-924093 & EPA 300.0 & RAB & 1 \\
\hline & & EPA 5030B/8260 & NPM & 70 \\
\hline & & EPA 504.1 & WAW & 1 \\
\hline \multirow[t]{3}{*}{6066709004} & EUPURGE-W-924094 & EPA 300.0 & $\mathrm{RAB}$ & 1 \\
\hline & & EPA 5030B/8260 & NPM & 70 \\
\hline & & EPA 504.1 & WAW & 1 \\
\hline \multirow[t]{3}{*}{6066709005} & MRPURGE-W-924095 & EPA 300.0 & $\mathrm{RAB}$ & 1 \\
\hline & & EPA 5030B/8260 & NPM & 70 \\
\hline & & EPA 504.1 & WAW & 1 \\
\hline 6066709006 & QCTB-W-924096 & EPA 5030B/8260 & NPM & 70 \\
\hline
\end{tabular}




\section{ANALYTICAL RESULTS}

Project: Kansas Waste Water

Pace Project No.: 6066709

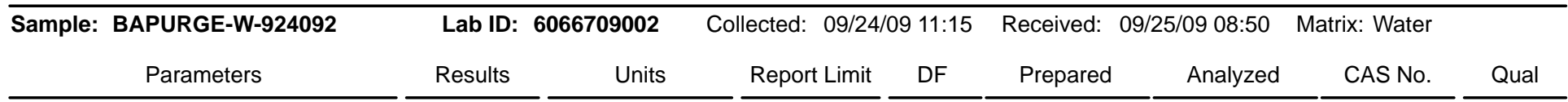

504 GCS EDB and DBCP

1,2-Dibromoethane (EDB)

\section{MSV}

Acetone

Benzene

Bromobenzene

Bromochloromethane

Bromodichloromethane

Bromoform

Bromomethane

2-Butanone (MEK)

n-Butylbenzene

sec-Butylbenzene

tert-Butylbenzene

Carbon disulfide

Carbon tetrachloride

Chlorobenzene

Chloroethane

Chloroform

Chloromethane

2-Chlorotoluene

4-Chlorotoluene

1,2-Dibromo-3-chloropropane

Dibromochloromethane

1,2-Dibromoethane (EDB)

Dibromomethane

1,2-Dichlorobenzene

1,3-Dichlorobenzene

1,4-Dichlorobenzene

Dichlorodifluoromethane

1,1-Dichloroethane

1,2-Dichloroethane

1,2-Dichloroethene (Total)

1,1-Dichloroethene

cis-1,2-Dichloroethene

trans-1,2-Dichloroethene

1,2-Dichloropropane

1,3-Dichloropropane

2,2-Dichloropropane

1,1-Dichloropropene

cis-1,3-Dichloropropene

trans-1,3-Dichloropropene

Ethylbenzene

Hexachloro-1,3-butadiene

2-Hexanone

Isopropylbenzene (Cumene)

p-Isopropyltoluene

Date: 10/13/2009 03:25 PM
Analytical Method: EPA 504.1 Preparation Method: EPA 504.1

$$
\begin{array}{llllllll}
\text { ND ug/L } & 0.047 & 1 & 10 / 08 / 09 & 00: 00 & 10 / 10 / 09 & 03: 45 & 106-93-4
\end{array}
$$

Analytical Method: EPA 5030B/8260

\begin{tabular}{|c|c|c|c|c|}
\hline ND ug/L & 10.0 & 1 & 09/28/09 21:22 & $67-64-1$ \\
\hline ND ug/L & 1.0 & 1 & 09/28/09 21:22 & $71-43-2$ \\
\hline ND ug/L & 1.0 & 1 & 09/28/09 21:22 & $108-86-1$ \\
\hline ND ug/L & 1.0 & 1 & 09/28/09 21:22 & $74-97-5$ \\
\hline ND ug/L & 1.0 & 1 & 09/28/09 21:22 & $75-27-4$ \\
\hline ND ug/L & 1.0 & 1 & 09/28/09 21:22 & $75-25-2$ \\
\hline ND ug/L & 1.0 & 1 & 09/28/09 21:22 & $74-83-9$ \\
\hline ND ug/L & 10.0 & 1 & 09/28/09 21:22 & $78-93-3$ \\
\hline ND ug/L & 1.0 & 1 & 09/28/09 21:22 & $104-51-8$ \\
\hline ND ug/L & 1.0 & 1 & 09/28/09 21:22 & $135-98-8$ \\
\hline ND ug/L & 1.0 & 1 & 09/28/09 21:22 & $98-06-6$ \\
\hline ND ug/L & 5.0 & 1 & 09/28/09 21:22 & $75-15-0$ \\
\hline ND ug/L & 1.0 & 1 & 09/28/09 21:22 & $56-23-5$ \\
\hline ND ug/L & 1.0 & 1 & 09/28/09 21:22 & $108-90-7$ \\
\hline ND ug/L & 1.0 & 1 & 09/28/09 21:22 & $75-00-3$ \\
\hline ND ug/L & 1.0 & 1 & 09/28/09 21:22 & $67-66-3$ \\
\hline ND ug/L & 1.0 & 1 & 09/28/09 21:22 & $74-87-3$ \\
\hline ND ug/L & 1.0 & 1 & 09/28/09 21:22 & $95-49-8$ \\
\hline ND ug/L & 1.0 & 1 & 09/28/09 21:22 & $106-43-4$ \\
\hline ND ug/L & 2.5 & 1 & 09/28/09 21:22 & $96-12-8$ \\
\hline ND ug/L & 1.0 & 1 & 09/28/09 21:22 & $124-48-1$ \\
\hline ND ug/L & 1.0 & 1 & 09/28/09 21:22 & $106-93-4$ \\
\hline ND ug/L & 1.0 & 1 & 09/28/09 21:22 & $74-95-3$ \\
\hline ND ug/L & 1.0 & 1 & 09/28/09 21:22 & $95-50-1$ \\
\hline ND ug/L & 1.0 & 1 & 09/28/09 21:22 & 541-73-1 \\
\hline ND ug/L & 1.0 & 1 & 09/28/09 21:22 & $106-46-7$ \\
\hline ND ug/L & 1.0 & 1 & 09/28/09 21:22 & $75-71-8$ \\
\hline ND ug/L & 1.0 & 1 & 09/28/09 21:22 & $75-34-3$ \\
\hline ND ug/L & 1.0 & 1 & 09/28/09 21:22 & $107-06-2$ \\
\hline ND ug/L & 1.0 & 1 & 09/28/09 21:22 & $540-59-0$ \\
\hline ND ug/L & 1.0 & 1 & 09/28/09 21:22 & $75-35-4$ \\
\hline ND ug/L & 1.0 & 1 & 09/28/09 21:22 & $156-59-2$ \\
\hline ND ug/L & 1.0 & 1 & 09/28/09 21:22 & $156-60-5$ \\
\hline ND ug/L & 1.0 & 1 & 09/28/09 21:22 & $78-87-5$ \\
\hline ND ug/L & 1.0 & 1 & 09/28/09 21:22 & $142-28-9$ \\
\hline ND ug/L & 1.0 & 1 & 09/28/09 21:22 & 594-20-7 \\
\hline ND ug/L & 1.0 & 1 & 09/28/09 21:22 & $563-58-6$ \\
\hline ND ug/L & 1.0 & 1 & 09/28/09 21:22 & $10061-01-5$ \\
\hline ND ug/L & 1.0 & 1 & 09/28/09 21:22 & $10061-02-6$ \\
\hline ND ug/L & 1.0 & 1 & 09/28/09 21:22 & $100-41-4$ \\
\hline ND ug/L & 1.0 & 1 & 09/28/09 21:22 & $87-68-3$ \\
\hline ND ug/L & 10.0 & 1 & 09/28/09 21:22 & $591-78-6$ \\
\hline ND ug/L & 1.0 & 1 & 09/28/09 21:22 & $98-82-8$ \\
\hline ND ug/L & 1.0 & 1 & 09/28/09 21:22 & $99-87-6$ \\
\hline
\end{tabular}

REPORT OF LABORATORY ANALYSIS

Page 7 of 23

This report shall not be reproduced, except in full,

without the written consent of Pace Analytical Services, Inc. 


\section{ANALYTICAL RESULTS}

Project: $\quad$ Kansas Waste Water

Pace Project No.: 6066709

Sample: BAPURGE-W-924092 Lab ID: $6066709002 \quad$ Collected: 09/24/09 11:15 $\quad$ Received: 09/25/09 08:50 Matrix: Water

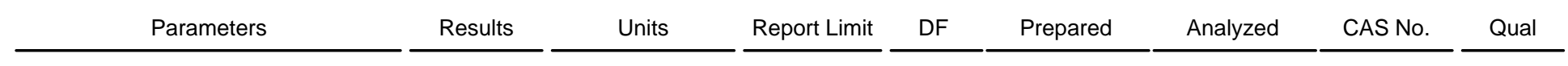

8260 MSV

Methylene chloride

4-Methyl-2-pentanone (MIBK)

Methyl-tert-butyl ether

Naphthalene

n-Propylbenzene

Styrene

1,1,1,2-Tetrachloroethane

1,1,2,2-Tetrachloroethane

Tetrachloroethene

Toluene

1,2,3-Trichlorobenzene

1,2,4-Trichlorobenzene

1,1,1-Trichloroethane

1,1,2-Trichloroethane

Trichloroethene

Trichlorofluoromethane

1,2,3-Trichloropropane

1,2,4-Trimethylbenzene

1,3,5-Trimethylbenzene

Vinyl chloride

Xylene (Total)

4-Bromofluorobenzene (S)

Dibromofluoromethane (S)

1,2-Dichloroethane-d4 (S)

Toluene-d8 (S)

Preservation $\mathrm{pH}$

\subsection{IC Anions}

Nitrate as $\mathrm{N}$
Analytical Method: EPA 5030B/8260

\begin{tabular}{|c|c|c|c|c|}
\hline ND ug/L & 1.0 & 1 & 09/28/09 21:22 & $75-09-2$ \\
\hline ND ug/L & 10.0 & 1 & 09/28/09 21:22 & $108-10-1$ \\
\hline ND ug/L & 1.0 & 1 & 09/28/09 21:22 & $1634-04-4$ \\
\hline ND ug/L & 10.0 & 1 & 09/28/09 21:22 & $91-20-3$ \\
\hline ND ug/L & 1.0 & 1 & 09/28/09 21:22 & $103-65-1$ \\
\hline ND ug/L & 1.0 & 1 & 09/28/09 21:22 & $100-42-5$ \\
\hline ND ug/L & 1.0 & 1 & 09/28/09 21:22 & $630-20-6$ \\
\hline ND ug/L & 1.0 & 1 & 09/28/09 21:22 & $79-34-5$ \\
\hline ND ug/L & 1.0 & 1 & 09/28/09 21:22 & $127-18-4$ \\
\hline ND ug/L & 1.0 & 1 & 09/28/09 21:22 & $108-88-3$ \\
\hline ND ug/L & 1.0 & 1 & 09/28/09 21:22 & $87-61-6$ \\
\hline ND ug/L & 1.0 & 1 & 09/28/09 21:22 & $120-82-1$ \\
\hline ND ug/L & 1.0 & 1 & 09/28/09 21:22 & $71-55-6$ \\
\hline ND ug/L & 1.0 & 1 & 09/28/09 21:22 & $79-00-5$ \\
\hline ND ug/L & 1.0 & 1 & 09/28/09 21:22 & $79-01-6$ \\
\hline ND ug/L & 1.0 & 1 & 09/28/09 21:22 & $75-69-4$ \\
\hline ND ug/L & 2.5 & 1 & 09/28/09 21:22 & $96-18-4$ \\
\hline ND ug/L & 1.0 & 1 & 09/28/09 21:22 & $95-63-6$ \\
\hline ND ug/L & 1.0 & 1 & 09/28/09 21:22 & $108-67-8$ \\
\hline ND ug/L & 1.0 & 1 & 09/28/09 21:22 & $75-01-4$ \\
\hline ND ug/L & 3.0 & 1 & 09/28/09 21:22 & $1330-20-7$ \\
\hline $105 \%$ & $87-115$ & 1 & 09/28/09 21:22 & $460-00-4$ \\
\hline $108 \%$ & $87-113$ & 1 & 09/28/09 21:22 & $1868-53-7$ \\
\hline $108 \%$ & $81-121$ & 1 & 09/28/09 21:22 & $17060-07-0$ \\
\hline $107 \%$ & $89-111$ & 1 & 09/28/09 21:22 & $2037-26-5$ \\
\hline 7.0 & 0.10 & 1 & 09/28/09 21:22 & \\
\hline
\end{tabular}

Analytical Method: EPA 300.0

$0.20 \mathrm{mg} / \mathrm{L}$

$0.10 \quad 1$

09/26/09 03:54 14797-55-8

This report shall not be reproduced, except in full, without the written consent of Pace Analytical Services, Inc. 


\section{ANALYTICAL RESULTS}

Project: Kansas Waste Water

Pace Project No.: 6066709

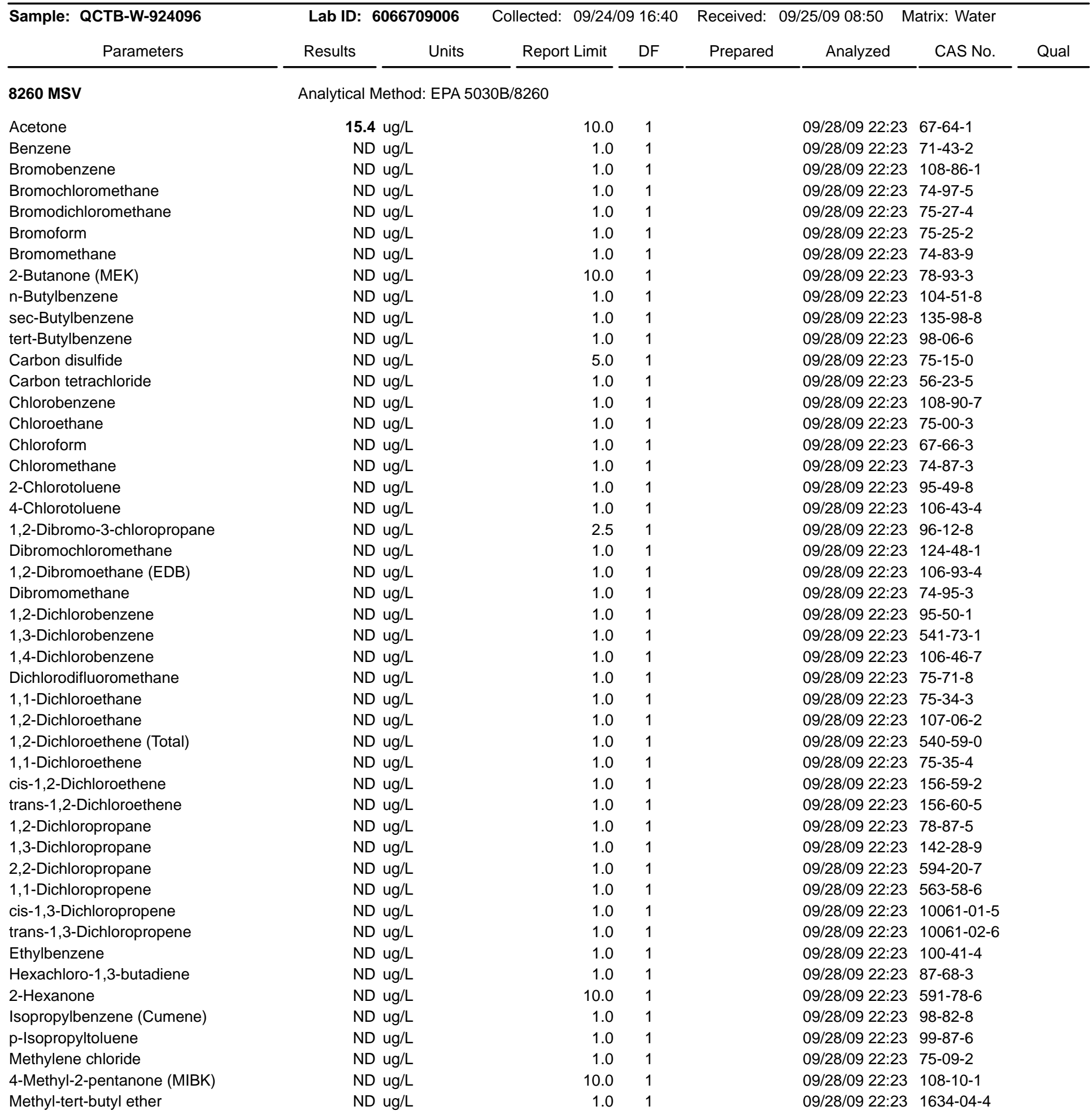

Date: 10/13/2009 03:25 PM

REPORT OF LABORATORY ANALYSIS

Page 15 of 23

This report shall not be reproduced, except in full,

without the written consent of Pace Analytical Services, Inc. 


\section{ANALYTICAL RESULTS}

Project: Kansas Waste Water

Pace Project No.: 6066709

\begin{tabular}{|c|c|c|c|c|c|c|c|}
\hline \multirow{2}{*}{$\begin{array}{c}\text { Sample: QCTB-W-924096 } \\
\text { Parameters }\end{array}$} & \multirow{2}{*}{\multicolumn{2}{|c|}{$\begin{array}{l}\text { Lab ID: } 6066709006 \\
\text { Results } \quad \text { Units }\end{array}$}} & \multicolumn{2}{|c|}{ Collected: 09/24/09 16:40 } & \multirow{2}{*}{$\begin{array}{l}\text { Received: } \\
\text { Prepared }\end{array}$} & \multirow{2}{*}{$\begin{array}{r}\text { 09/25/09 08:50 } \\
\text { Analyzed }\end{array}$} & \multirow{2}{*}{$\begin{array}{r}\text { Matrix: Water } \\
\text { CAS No. }\end{array}$} \\
\hline & & & Report Limit & DF & & & \\
\hline 8260 MSV & \multicolumn{4}{|c|}{ Analytical Method: EPA 5030B/8260 } & & & \\
\hline Naphthalene & & & 10.0 & 1 & & 09/28/09 22:23 & $391-20-3$ \\
\hline n-Propylbenzene & & & 1.0 & 1 & & 09/28/09 22:23 & $3103-65-1$ \\
\hline Styrene & & & 1.0 & 1 & & 09/28/09 22:23 & $3100-42-5$ \\
\hline 1,1,1,2-Tetrachloroethane & & & 1.0 & 1 & & 09/28/09 22:23 & $3630-20-6$ \\
\hline 1,1,2,2-Tetrachloroethane & & & 1.0 & 1 & & 09/28/09 22:23 & $79-34-5$ \\
\hline Tetrachloroethene & & & 1.0 & 1 & & 09/28/09 22:23 & $3127-18-4$ \\
\hline Toluene & & & 1.0 & 1 & & 09/28/09 22:23 & $3108-88-3$ \\
\hline 1,2,3-Trichlorobenzene & & & 1.0 & 1 & & 09/28/09 22:23 & $87-61-6$ \\
\hline 1,2,4-Trichlorobenzene & & & 1.0 & 1 & & 09/28/09 22:23 & $120-82-1$ \\
\hline 1,1,1-Trichloroethane & & & 1.0 & 1 & & 09/28/09 22:23 & $31-55-6$ \\
\hline 1,1,2-Trichloroethane & & & 1.0 & 1 & & 09/28/09 22:23 & $379-00-5$ \\
\hline Trichloroethene & & & 1.0 & 1 & & 09/28/09 22:23 & 39-01-6 \\
\hline Trichlorofluoromethane & & & 1.0 & 1 & & 09/28/09 22:23 & $375-69-4$ \\
\hline 1,2,3-Trichloropropane & & & 2.5 & 1 & & 09/28/09 22:23 & 96-18-4 \\
\hline 1,2,4-Trimethylbenzene & & & 1.0 & 1 & & 09/28/09 22:23 & 95-63-6 \\
\hline 1,3,5-Trimethylbenzene & & & 1.0 & 1 & & 09/28/09 22:23 & $3108-67-8$ \\
\hline Vinyl chloride & & & 1.0 & 1 & & 09/28/09 22:23 & 75-01-4 \\
\hline Xylene (Total) & & & 3.0 & 1 & & 09/28/09 22:23 & $1330-20-7$ \\
\hline 4-Bromofluorobenzene (S) & 10 & & $87-115$ & 1 & & 09/28/09 22:23 & $3460-00-4$ \\
\hline Dibromofluoromethane (S) & 10 & & $87-113$ & 1 & & 09/28/09 22:23 & 1868-53-7 \\
\hline 1,2-Dichloroethane-d4 (S) & 10 & & $81-121$ & 1 & & 09/28/09 22:23 & 3 $17060-07-0$ \\
\hline Toluene-d8 (S) & 10 & & $89-111$ & 1 & & 09/28/09 22:23 & $2037-26-5$ \\
\hline Preservation $\mathrm{pH}$ & 7. & & 0.10 & 1 & & 09/28/09 22:23 & \\
\hline
\end{tabular}

This report shall not be reproduced, except in full, without the written consent of Pace Analytical Services, Inc. 


\section{QUALITY CONTROL DATA}

Project: Kansas Waste Water

Pace Project No.: 6066709

\begin{tabular}{llll}
\hline QC Batch: & WETA/10995 & Analysis Method: & EPA 300.0 \\
QC Batch Method: & EPA 300.0 & Analysis Description: & 300.0 IC Anions
\end{tabular}

Associated Lab Samples: $\quad 6066709001,6066709002,6066709003,6066709004,6066709005$

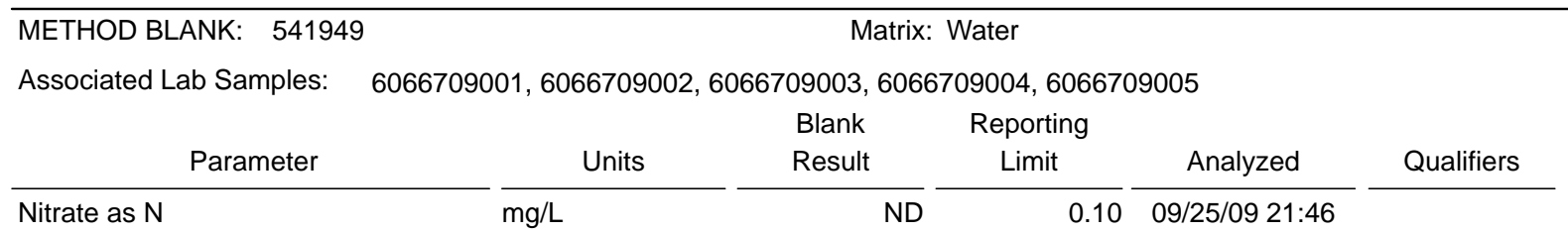

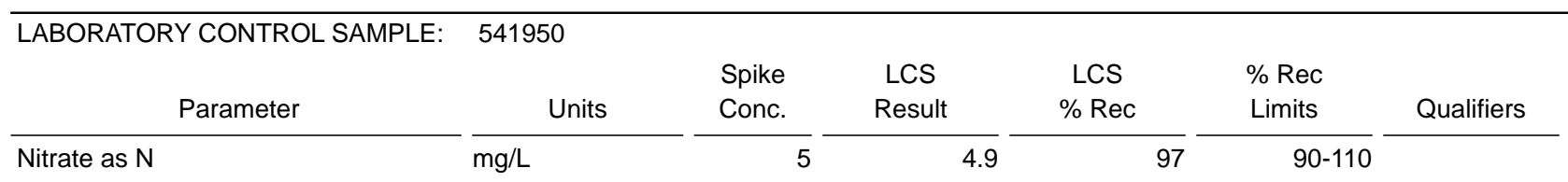

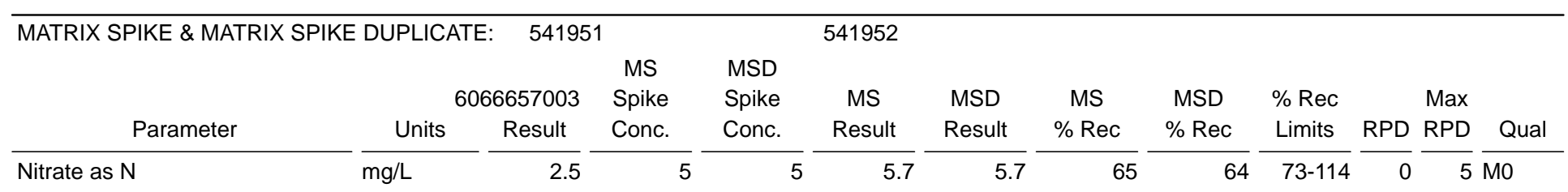

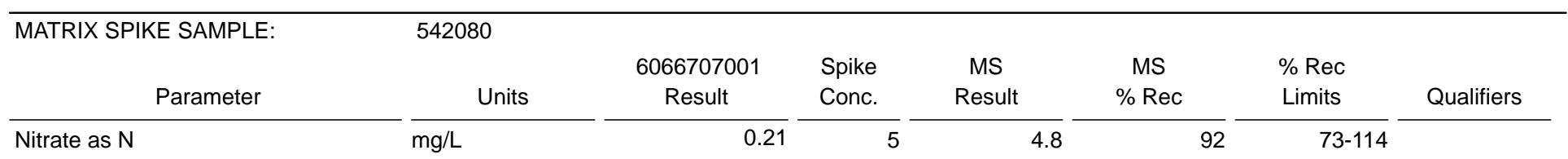




\section{QUALITY CONTROL DATA}

Project: Kansas Waste Water

Pace Project No.: 6066709

\begin{tabular}{llll}
\hline QC Batch: & MSV/23759 & Analysis Method: & EPA 5030B/8260 \\
QC Batch Method: & EPA 5030B/8260 & Analysis Description: & 8260 MSV Water 7 day
\end{tabular}

Associated Lab Samples: $\quad$ 6066709001, 6066709002, 6066709003, 6066709004, 6066709005, 6066709006

\begin{tabular}{|c|c|c|c|c|c|}
\hline METHOD BLANK: 548226 & & Matrix: & Vater & & \\
\hline Associated Lab Samples: & 01,6066709 & 709003,6066 & $99004,60667 c$ & 9005,6066709006 & \\
\hline Parameter & Units & $\begin{array}{l}\text { Blank } \\
\text { Result }\end{array}$ & $\begin{array}{l}\text { Reporting } \\
\text { Limit }\end{array}$ & Analyzed & Qualifiers \\
\hline 1,1,1,2-Tetrachloroethane & $\mathrm{ug} / \mathrm{L}$ & ND & 1.0 & 09/28/09 20:06 & \\
\hline 1,1,1-Trichloroethane & $\mathrm{ug} / \mathrm{L}$ & ND & 1.0 & 09/28/09 20:06 & \\
\hline 1,1,2,2-Tetrachloroethane & $u g / L$ & ND & 1.0 & 09/28/09 20:06 & \\
\hline 1,1,2-Trichloroethane & $\mathrm{ug} / \mathrm{L}$ & ND & 1.0 & 09/28/09 20:06 & \\
\hline 1,1-Dichloroethane & $\mathrm{ug} / \mathrm{L}$ & ND & 1.0 & 09/28/09 20:06 & \\
\hline 1,1-Dichloroethene & $u g / L$ & ND & 1.0 & 09/28/09 20:06 & \\
\hline 1,1-Dichloropropene & $\mathrm{ug} / \mathrm{L}$ & ND & 1.0 & 09/28/09 20:06 & \\
\hline 1,2,3-Trichlorobenzene & $\mathrm{ug} / \mathrm{L}$ & ND & 1.0 & 09/28/09 20:06 & \\
\hline 1,2,3-Trichloropropane & $\mathrm{ug} / \mathrm{L}$ & ND & 2.5 & 09/28/09 20:06 & \\
\hline 1,2,4-Trichlorobenzene & $\mathrm{ug} / \mathrm{L}$ & ND & 1.0 & 09/28/09 20:06 & \\
\hline 1,2,4-Trimethylbenzene & $\mathrm{ug} / \mathrm{L}$ & ND & 1.0 & 09/28/09 20:06 & \\
\hline 1,2-Dibromo-3-chloropropane & $\mathrm{ug} / \mathrm{L}$ & ND & 2.5 & 09/28/09 20:06 & \\
\hline 1,2-Dibromoethane (EDB) & $\mathrm{ug} / \mathrm{L}$ & ND & 1.0 & 09/28/09 20:06 & \\
\hline 1,2-Dichlorobenzene & $\mathrm{ug} / \mathrm{L}$ & ND & 1.0 & 09/28/09 20:06 & \\
\hline 1,2-Dichloroethane & $\mathrm{ug} / \mathrm{L}$ & ND & 1.0 & 09/28/09 20:06 & \\
\hline 1,2-Dichloroethene (Total) & $\mathrm{ug} / \mathrm{L}$ & ND & 1.0 & 09/28/09 20:06 & \\
\hline 1,2-Dichloropropane & $\mathrm{ug} / \mathrm{L}$ & ND & 1.0 & 09/28/09 20:06 & \\
\hline 1,3,5-Trimethylbenzene & $\mathrm{ug} / \mathrm{L}$ & ND & 1.0 & 09/28/09 20:06 & \\
\hline 1,3-Dichlorobenzene & $\mathrm{ug} / \mathrm{L}$ & ND & 1.0 & 09/28/09 20:06 & \\
\hline 1,3-Dichloropropane & $\mathrm{ug} / \mathrm{L}$ & ND & 1.0 & 09/28/09 20:06 & \\
\hline 1,4-Dichlorobenzene & $\mathrm{ug} / \mathrm{L}$ & ND & 1.0 & 09/28/09 20:06 & \\
\hline 2,2-Dichloropropane & $u g / L$ & ND & 1.0 & 09/28/09 20:06 & \\
\hline 2-Butanone (MEK) & $\mathrm{ug} / \mathrm{L}$ & ND & 10.0 & 09/28/09 20:06 & \\
\hline 2-Chlorotoluene & $\mathrm{ug} / \mathrm{L}$ & ND & 1.0 & 09/28/09 20:06 & \\
\hline 2-Hexanone & $\mathrm{ug} / \mathrm{L}$ & ND & 10.0 & 09/28/09 20:06 & \\
\hline 4-Chlorotoluene & $\mathrm{ug} / \mathrm{L}$ & ND & 1.0 & 09/28/09 20:06 & \\
\hline 4-Methyl-2-pentanone (MIBK) & $\mathrm{ug} / \mathrm{L}$ & ND & 10.0 & 09/28/09 20:06 & \\
\hline Acetone & $\mathrm{ug} / \mathrm{L}$ & ND & 10.0 & 09/28/09 20:06 & \\
\hline Benzene & $\mathrm{ug} / \mathrm{L}$ & ND & 1.0 & 09/28/09 20:06 & \\
\hline Bromobenzene & $\mathrm{ug} / \mathrm{L}$ & ND & 1.0 & 09/28/09 20:06 & \\
\hline Bromochloromethane & $\mathrm{ug} / \mathrm{L}$ & ND & 1.0 & 09/28/09 20:06 & \\
\hline Bromodichloromethane & $\mathrm{ug} / \mathrm{L}$ & ND & 1.0 & 09/28/09 20:06 & \\
\hline Bromoform & $\mathrm{ug} / \mathrm{L}$ & ND & 1.0 & 09/28/09 20:06 & \\
\hline Bromomethane & $\mathrm{ug} / \mathrm{L}$ & ND & 1.0 & 09/28/09 20:06 & \\
\hline Carbon disulfide & $\mathrm{ug} / \mathrm{L}$ & ND & 5.0 & 09/28/09 20:06 & \\
\hline Carbon tetrachloride & $\mathrm{ug} / \mathrm{L}$ & ND & 1.0 & 09/28/09 20:06 & \\
\hline Chlorobenzene & $\mathrm{ug} / \mathrm{L}$ & ND & 1.0 & 09/28/09 20:06 & \\
\hline Chloroethane & $\mathrm{ug} / \mathrm{L}$ & ND & 1.0 & 09/28/09 20:06 & \\
\hline Chloroform & $\mathrm{ug} / \mathrm{L}$ & ND & 1.0 & 09/28/09 20:06 & \\
\hline Chloromethane & $\mathrm{ug} / \mathrm{L}$ & ND & 1.0 & 09/28/09 20:06 & \\
\hline cis-1,2-Dichloroethene & $\mathrm{ug} / \mathrm{L}$ & ND & 1.0 & 09/28/09 20:06 & \\
\hline cis-1,3-Dichloropropene & $\mathrm{ug} / \mathrm{L}$ & ND & 1.0 & 09/28/09 20:06 & \\
\hline Dibromochloromethane & $\mathrm{ug} / \mathrm{L}$ & ND & 1.0 & 09/28/09 20:06 & \\
\hline
\end{tabular}




\section{QUALITY CONTROL DATA}

Project: Kansas Waste Water

Pace Project No.: 6066709

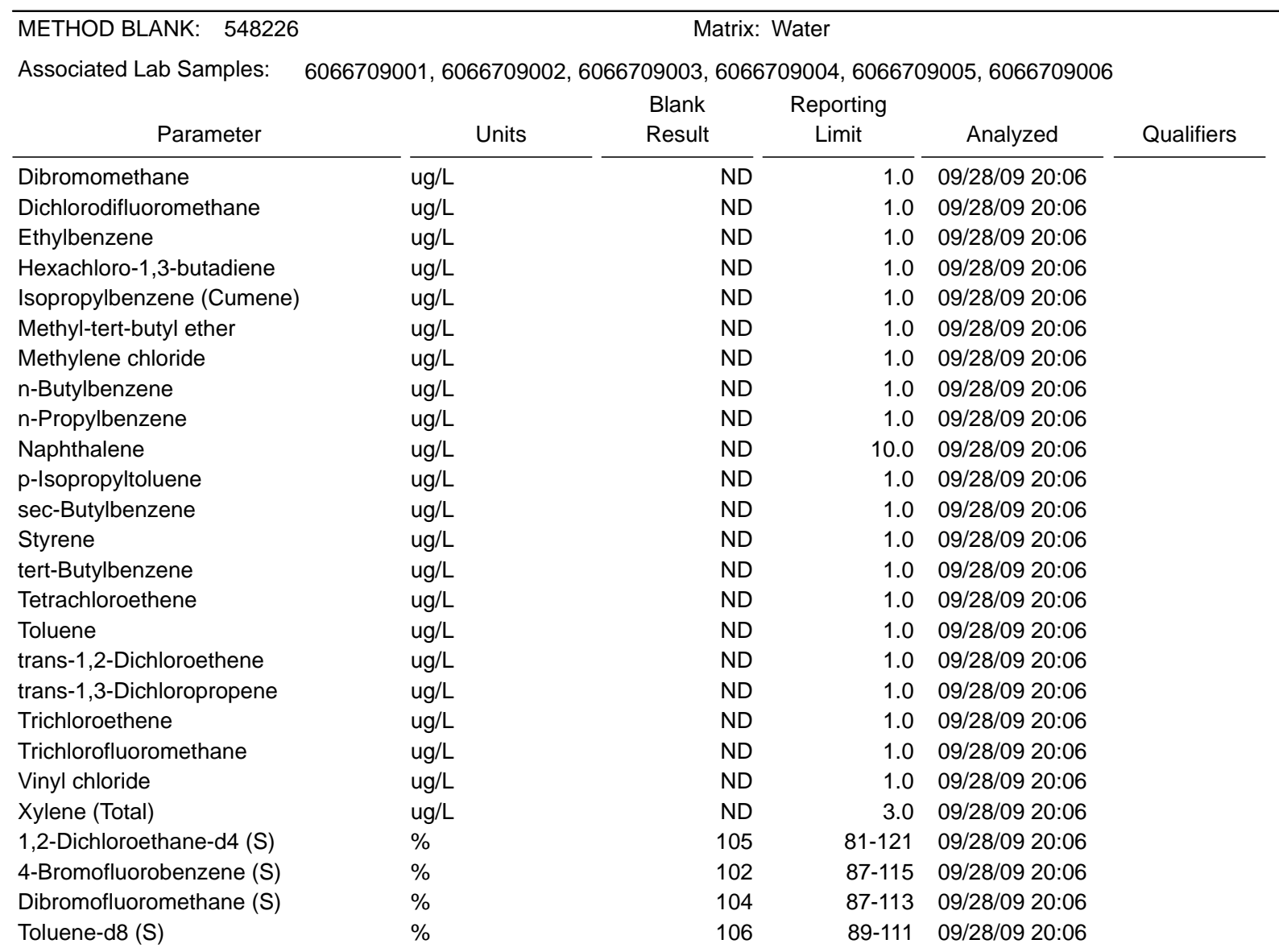

\begin{tabular}{|c|c|c|c|c|c|c|}
\hline \multirow{2}{*}{$\begin{array}{c}\text { LABORATORY CONTROL SAMPLE: } \\
\text { Parameter }\end{array}$} & \multicolumn{6}{|l|}{548227} \\
\hline & Units & $\begin{array}{l}\text { Spike } \\
\text { Conc. }\end{array}$ & $\begin{array}{l}\text { LCS } \\
\text { Result }\end{array}$ & $\begin{array}{l}\text { LCS } \\
\% \operatorname{Rec}\end{array}$ & $\begin{array}{l}\% \text { Rec } \\
\text { Limits }\end{array}$ & Qualifiers \\
\hline $1,1,1,2$-Tetrachloroethane & $\mathrm{ug} / \mathrm{L}$ & 10 & 7.6 & 76 & $75-121$ & \\
\hline 1,1,1-Trichloroethane & $\mathrm{ug} / \mathrm{L}$ & 10 & 8.8 & 88 & $73-120$ & \\
\hline 1,1,2,2-Tetrachloroethane & $\mathrm{ug} / \mathrm{L}$ & 10 & 10 & 100 & $73-128$ & \\
\hline 1,1,2-Trichloroethane & ug/L & 10 & 10.4 & 104 & $83-125$ & \\
\hline 1,1-Dichloroethane & $u g / L$ & 10 & 9.8 & 98 & $79-115$ & \\
\hline 1,1-Dichloroethene & $\mathrm{ug} / \mathrm{L}$ & 10 & 10.2 & 102 & $76-122$ & \\
\hline 1,1-Dichloropropene & ug/L & 10 & 10.5 & 105 & $80-119$ & \\
\hline 1,2,3-Trichlorobenzene & $\mathrm{ug} / \mathrm{L}$ & 10 & 9.5 & 95 & $70-138$ & \\
\hline 1,2,3-Trichloropropane & $\mathrm{ug} / \mathrm{L}$ & 10 & 10.3 & 103 & $74-129$ & \\
\hline 1,2,4-Trichlorobenzene & ug/L & 10 & 9.0 & 90 & $72-131$ & \\
\hline 1,2,4-Trimethylbenzene & ug/L & 10 & 9.2 & 92 & $78-123$ & \\
\hline 1,2-Dibromo-3-chloropropane & $\mathrm{ug} / \mathrm{L}$ & 10 & 8.9 & 89 & $61-139$ & \\
\hline 1,2-Dibromoethane (EDB) & $\mathrm{ug} / \mathrm{L}$ & 10 & 10 & 100 & $80-124$ & \\
\hline 1,2-Dichlorobenzene & $\mathrm{ug} / \mathrm{L}$ & 10 & 9.4 & 94 & $82-113$ & \\
\hline 1,2-Dichloroethane & $\mathrm{ug} / \mathrm{L}$ & 10 & 10.9 & 109 & $78-118$ & \\
\hline
\end{tabular}




\section{QUALITY CONTROL DATA}

Project: Kansas Waste Water

Pace Project No.: 6066709

\begin{tabular}{|c|c|c|c|c|c|c|}
\hline LABORATORY CONTROL SAMPLE: & 548227 & & & & & \\
\hline Parameter & Units & $\begin{array}{l}\text { Spike } \\
\text { Conc. }\end{array}$ & $\begin{array}{l}\text { LCS } \\
\text { Result }\end{array}$ & $\begin{array}{c}\text { LCS } \\
\% \operatorname{Rec}\end{array}$ & $\begin{array}{l}\% \operatorname{Rec} \\
\text { Limits }\end{array}$ & Qualifiers \\
\hline 1,2-Dichloroethene (Total) & $\mathrm{ug} / \mathrm{L}$ & 20 & 21.5 & 107 & $79-120$ & \\
\hline 1,2-Dichloropropane & $\mathrm{ug} / \mathrm{L}$ & 10 & 10.9 & 109 & $83-117$ & \\
\hline 1,3,5-Trimethylbenzene & $u g / L$ & 10 & 9.3 & 93 & $79-116$ & \\
\hline 1,3-Dichlorobenzene & $\mathrm{ug} / \mathrm{L}$ & 10 & 9.1 & 91 & $82-112$ & \\
\hline 1,3-Dichloropropane & $\mathrm{ug} / \mathrm{L}$ & 10 & 10.4 & 104 & $82-121$ & \\
\hline 1,4-Dichlorobenzene & $u g / L$ & 10 & 9.1 & 91 & $81-111$ & \\
\hline 2,2-Dichloropropane & $\mathrm{ug} / \mathrm{L}$ & 10 & 6.3 & 63 & $55-139$ & \\
\hline 2-Butanone (MEK) & $\mathrm{ug} / \mathrm{L}$ & 25 & 29.6 & 119 & $61-136$ & \\
\hline 2-Chlorotoluene & ug/L & 10 & 9.1 & 91 & $81-115$ & \\
\hline 2-Hexanone & $\mathrm{ug} / \mathrm{L}$ & 25 & 27.8 & 111 & $65-137$ & \\
\hline 4-Chlorotoluene & $\mathrm{ug} / \mathrm{L}$ & 10 & 9.2 & 92 & $81-111$ & \\
\hline 4-Methyl-2-pentanone (MIBK) & $\mathrm{ug} / \mathrm{L}$ & 25 & 32.1 & 129 & $65-133$ & \\
\hline Acetone & $\mathrm{ug} / \mathrm{L}$ & 25 & 27.7 & 111 & $58-126$ & \\
\hline Benzene & $\mathrm{ug} / \mathrm{L}$ & 10 & 10.8 & 108 & $81-114$ & \\
\hline Bromobenzene & $u g / L$ & 10 & 9.3 & 93 & $84-113$ & \\
\hline Bromochloromethane & $\mathrm{ug} / \mathrm{L}$ & 10 & 11.2 & 112 & $79-120$ & \\
\hline Bromodichloromethane & $\mathrm{ug} / \mathrm{L}$ & 10 & 10.0 & 100 & $75-119$ & \\
\hline Bromoform & $\mathrm{ug} / \mathrm{L}$ & 10 & 6.8 & 68 & $66-132$ & \\
\hline Bromomethane & $\mathrm{ug} / \mathrm{L}$ & 10 & 5.8 & 58 & $58-151$ & \\
\hline Carbon disulfide & $\mathrm{ug} / \mathrm{L}$ & 10 & 10.9 & 109 & $49-148$ & \\
\hline Carbon tetrachloride & $\mathrm{ug} / \mathrm{L}$ & 10 & 7.4 & 74 & $62-137$ & \\
\hline Chlorobenzene & $\mathrm{ug} / \mathrm{L}$ & 10 & 9.9 & 99 & $81-113$ & \\
\hline Chloroethane & $u g / L$ & 10 & 12.4 & 124 & $65-119$ & \\
\hline Chloroform & $\mathrm{ug} / \mathrm{L}$ & 10 & 10.4 & 104 & $76-118$ & \\
\hline Chloromethane & $\mathrm{ug} / \mathrm{L}$ & 10 & 9.6 & 96 & $40-132$ & \\
\hline cis-1,2-Dichloroethene & $\mathrm{ug} / \mathrm{L}$ & 10 & 10.8 & 108 & $80-119$ & \\
\hline cis-1,3-Dichloropropene & $\mathrm{ug} / \mathrm{L}$ & 10 & 9.5 & 95 & $75-122$ & \\
\hline Dibromochloromethane & $\mathrm{ug} / \mathrm{L}$ & 10 & 8.4 & 84 & $72-124$ & \\
\hline Dibromomethane & $\mathrm{ug} / \mathrm{L}$ & 10 & 11.0 & 110 & $79-121$ & \\
\hline Dichlorodifluoromethane & $\mathrm{ug} / \mathrm{L}$ & 10 & 8.1 & 81 & $11-156$ & \\
\hline Ethylbenzene & $u g / L$ & 10 & 9.6 & 96 & $82-115$ & \\
\hline Hexachloro-1,3-butadiene & $\mathrm{ug} / \mathrm{L}$ & 10 & 8.3 & 83 & $72-139$ & \\
\hline Isopropylbenzene (Cumene) & $\mathrm{ug} / \mathrm{L}$ & 10 & 8.4 & 84 & $69-103$ & \\
\hline Methyl-tert-butyl ether & $\mathrm{ug} / \mathrm{L}$ & 10 & 9.4 & 94 & $65-113$ & \\
\hline Methylene chloride & $\mathrm{ug} / \mathrm{L}$ & 10 & 10.0 & 100 & $76-124$ & \\
\hline n-Butylbenzene & $\mathrm{ug} / \mathrm{L}$ & 10 & 9.1 & 91 & $77-121$ & \\
\hline n-Propylbenzene & $\mathrm{ug} / \mathrm{L}$ & 10 & 8.9 & 89 & $79-116$ & \\
\hline Naphthalene & $\mathrm{ug} / \mathrm{L}$ & 10 & 10.6 & 106 & $66-132$ & \\
\hline p-Isopropyltoluene & $\mathrm{ug} / \mathrm{L}$ & 10 & 8.8 & 88 & $77-114$ & \\
\hline sec-Butylbenzene & $\mathrm{ug} / \mathrm{L}$ & 10 & 9.1 & 91 & $80-119$ & \\
\hline Styrene & $\mathrm{ug} / \mathrm{L}$ & 10 & 10.1 & 101 & $81-115$ & \\
\hline tert-Butylbenzene & $\mathrm{ug} / \mathrm{L}$ & 10 & 9.2 & 92 & $77-121$ & \\
\hline Tetrachloroethene & $\mathrm{ug} / \mathrm{L}$ & 10 & 9.2 & 92 & $73-122$ & \\
\hline Toluene & $\mathrm{ug} / \mathrm{L}$ & 10 & 10.6 & 106 & $82-114$ & \\
\hline trans-1,2-Dichloroethene & $\mathrm{ug} / \mathrm{L}$ & 10 & 10.7 & 107 & $75-122$ & \\
\hline trans-1,3-Dichloropropene & $\mathrm{ug} / \mathrm{L}$ & 10 & 6.5 & 65 & $66-114$ & \\
\hline Trichloroethene & $\mathrm{ug} / \mathrm{L}$ & 10 & 10.6 & 106 & $78-119$ & \\
\hline Trichlorofluoromethane & $\mathrm{ug} / \mathrm{L}$ & 10 & 9.7 & 97 & $71-120$ & \\
\hline
\end{tabular}

This report shall not be reproduced, except in full, without the written consent of Pace Analytical Services, Inc. 


\section{QUALITY CONTROL DATA}

Project: Kansas Waste Water

Pace Project No.: 6066709

\begin{tabular}{|c|c|c|c|c|c|c|}
\hline LABORATORY CONTROL SAMPLE: & 548227 & & & & & \\
\hline Parameter & Units & $\begin{array}{l}\text { Spike } \\
\text { Conc. }\end{array}$ & $\begin{array}{l}\text { LCS } \\
\text { Result }\end{array}$ & $\begin{array}{l}\text { LCS } \\
\% \operatorname{Rec}\end{array}$ & $\begin{array}{l}\% \operatorname{Rec} \\
\text { Limits }\end{array}$ & Qualifiers \\
\hline Vinyl chloride & $\mathrm{ug} / \mathrm{L}$ & 10 & 9.2 & 92 & $67-139$ & \\
\hline Xylene (Total) & $\mathrm{ug} / \mathrm{L}$ & 30 & 26.9 & 90 & $81-116$ & \\
\hline 1,2-Dichloroethane-d4 (S) & $\%$ & & & 104 & $81-121$ & \\
\hline 4-Bromofluorobenzene (S) & $\%$ & & & 101 & $87-115$ & \\
\hline Dibromofluoromethane (S) & $\%$ & & & 105 & $87-113$ & \\
\hline Toluene-d8 (S) & $\%$ & & & 105 & $89-111$ & \\
\hline
\end{tabular}




\section{QUALITY CONTROL DATA}

Project: Kansas Waste Water

Pace Project No.: 6066709

\begin{tabular}{llll}
\hline QC Batch: & OEXT/19948 & Analysis Method: & EPA 504.1 \\
QC Batch Method: & EPA 504.1 & Analysis Description: & GCS 504 EDB DBCP
\end{tabular}

Associated Lab Samples: $\quad$ 6066709001, 6066709002, 6066709003, 6066709004, 6066709005

METHOD BLANK: $548830 \quad$ Matrix: Water

Associated Lab Samples: $\quad$ 6066709001, 6066709002, 6066709003, 6066709004, 6066709005

$\frac{\text { Parameter }}{1,2 \text {-Dibromoethane (EDB) }} \frac{\text { Units }}{\mathrm{ug} / \mathrm{L}} \frac{\text { Result }}{\mathrm{ND}} \frac{\begin{array}{c}\text { Blank } \\ \text { Limit }\end{array}}{0.050} \frac{\text { Analyzed }}{10 / 09 / 0915: 13} \frac{\text { Qualifiers }}{-}$

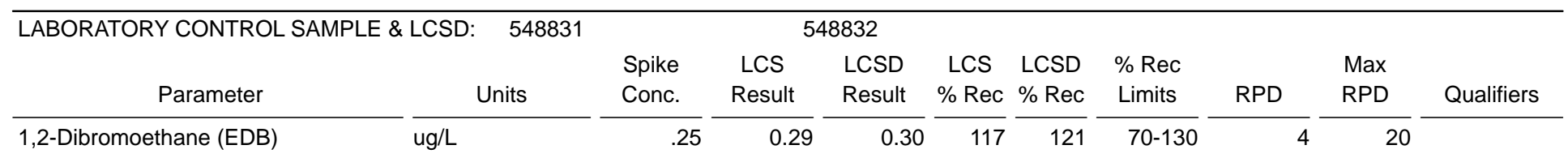




\section{QUALIFIERS}

Project: $\quad$ Kansas Waste Water

Pace Project No.: 6066709

\section{DEFINITIONS}

DF - Dilution Factor, if reported, represents the factor applied to the reported data due to changes in sample preparation, dilution of the sample aliquot, or moisture content.

ND - Not Detected at or above adjusted reporting limit.

$\mathrm{J}$ - Estimated concentration above the adjusted method detection limit and below the adjusted reporting limit.

MDL - Adjusted Method Detection Limit.

$S$ - Surrogate

1,2-Diphenylhydrazine (8270 listed analyte) decomposes to Azobenzene.

Consistent with EPA guidelines, unrounded data are displayed and have been used to calculate \% recovery and RPD values.

LCS(D) - Laboratory Control Sample (Duplicate)

MS(D) - Matrix Spike (Duplicate)

DUP - Sample Duplicate

RPD - Relative Percent Difference

Pace Analytical is NELAP accredited. Contact your Pace PM for the current list of accredited analytes.

$\mathrm{U}$ - Indicates the compound was analyzed for, but not detected.

\section{BATCH QUALIFIERS}

Batch: MSV/23759

[M5] A matrix spike/matrix spike duplicate was not performed for this batch due to insufficient sample volume.

\section{ANALYTE QUALIFIERS}

L2 Analyte recovery in the laboratory control sample (LCS) was below QC limits. Results for this analyte in associated samples may be biased low.

L3 Analyte recovery in the laboratory control sample (LCS) exceeded QC limits. Analyte presence below reporting limits in associated samples. Results unaffected by high bias.

M0 Matrix spike recovery and/or matrix spike duplicate recovery was outside laboratory control limits. 


\section{Appendix C:}

Results from the AGEM Laboratory for Dual Analyses of Samples Collected at Barnes in September-October and December 2009 and for Quality Control Samples 
TABLE C.1 Analytical results for samples and replicates collected at Barnes during the September-October 2009 monitoring event and for quality control samples.

\begin{tabular}{|c|c|c|c|c|c|c|c|}
\hline \multirow[b]{2}{*}{$\begin{array}{c}\text { Sample } \\
\text { Date }\end{array}$} & \multirow[b]{2}{*}{ Location } & \multirow[b]{2}{*}{$\begin{array}{l}\text { Depth } \\
\text { (ft BGL) }\end{array}$} & \multirow[b]{2}{*}{ Sample } & \multirow[b]{2}{*}{ Analysis Type } & \multicolumn{3}{|c|}{ Concentration $(\mu \mathrm{g} / \mathrm{L})$} \\
\hline & & & & & $\begin{array}{c}\text { Carbon } \\
\text { Tetrachloride }\end{array}$ & Chloroform & $\begin{array}{c}\text { Methylene } \\
\text { Chloride }\end{array}$ \\
\hline $9 / 30 / 09$ & MW2D & $133.26-152.93$ & BAMW2D-W-28679 & Primary & $N D^{a}$ & ND & ND \\
\hline $9 / 30 / 09$ & MW2D & $133.26-152.93$ & BAMW2DDUP-W-28709 & Replciate & ND & ND & ND \\
\hline $9 / 30 / 09$ & MW3D & $133.02-152.73$ & BAMW3D-W-28680 & Primary & ND & ND & ND \\
\hline $9 / 30 / 09$ & MW3D & $133.02-152.73$ & BAMW3DDUP-W-28708 & Replciate & ND & ND & ND \\
\hline $9 / 30 / 09$ & MW10S & $93-103$ & BAMW10S-W-28688 & Primary & 53 & 2.4 & ND \\
\hline $9 / 30 / 09$ & MW10S & $93-103$ & BAMW10S-W-28688DUP & Duplicate & 53 & 2.4 & ND \\
\hline $9 / 30 / 09$ & MW13S & $112-122$ & BAMW13S-W-28696 & Primary & 12 & $0.9 \mathrm{Jb}^{\mathrm{b}}$ & ND \\
\hline $9 / 30 / 09$ & MW13S & $112-122$ & BAMW13S-W-28696DUP & Duplicate & 13 & $0.9 \mathrm{~J}$ & ND \\
\hline 9/30/09 & Oentrich & 150 & BAOENTRICH-W-28705 & Primary & 1.6 & ND & ND \\
\hline $9 / 30 / 09$ & Oentrich & 150 & BAOENT-W-28705DUP & Duplicate & 1.5 & ND & ND \\
\hline $9 / 30 / 09$ & QC & - & BAQCIR-W-28711 & Rinsate after MW1D & ND & ND & ND \\
\hline $9 / 30 / 09$ & QC & - & BAQCIR-W-28712 & Rinsate after MW10D & ND & ND & ND \\
\hline $9 / 30 / 09$ & QC & - & BAQCTB-W-28713 & Trip blank & ND & ND & ND \\
\hline $10 / 1 / 09$ & QC & - & BAQCTB-W-28714 & Trip blank & ND & ND & ND \\
\hline $12 / 14 / 09$ & QC & - & BAQCTB-W-28717 & Trip blank & ND & ND & ND \\
\hline
\end{tabular}

a ND, contaminant not detected at an instrument detection limit of $0.1 \mu \mathrm{g} / \mathrm{L}$.

b Qualifier J indicates an estimated concentration below the method quantitation limit of $1.0 \mu \mathrm{g} / \mathrm{L}$. 


\section{Appendix D:}

Sample Documentation from TestAmerica Laboratories, Inc. 


\section{TestAmerica}

THE LEADER IN ENYIRONMENTAL TESTING

TestAmerica Laboratories, Inc.

October 26, 2009

Mr. Clyde Dennis

Argonne National Laboratory

9700 S. Cass Avenue

Bldg. 203, Office B149

Argonne, IL 60439

Re: Laboratory Project No. 21005

Case: BARNES: SDG: 133894

Dear Mr. Dennis:

Enclosed are analytical results for samples that were received by TestAmerica Burlington on October $1^{\text {st }}, 2009$. Laboratory identification numbers were assigned, and designated as follows:

\begin{tabular}{llll} 
Lab ID & $\begin{array}{l}\text { Client } \\
\text { Sample ID }\end{array}$ & $\begin{array}{l}\text { Sample } \\
\text { Date }\end{array}$ & $\begin{array}{l}\text { Sample } \\
\text { Matrix }\end{array}$ \\
\cline { 2 - 4 } & Received: 10/01/09 ETR No: 133894 & \\
808349 & BAMW15S-W-28700 & $09 / 29 / 09$ & WATER \\
808350 & BAMW16D-W-28703 & $09 / 29 / 09$ & WATER \\
808351 & BAMW13D-W-28697 & $09 / 30 / 09$ & WATER \\
808352 & BAMW17-W-28704 & $09 / 30 / 09$ & WATER \\
808353 & BAPWS3-W-28707. & $09 / 30 / 09$ & WATER \\
808354 & BAQCTB-W-28713 & $09 / 30 / 09$ & WATER \\
808355 & VHBLK01 & $10 / 01 / 09$ & WATER
\end{tabular}

Documentation of the condition of the samples at the time of their receipt and any exception to the laboratory's Sample Acceptance Policy is documented in the Sample Handling section of this submittal. The samples, as received, were not acid preserved. On that basis, the laboratory did provide for the analytical work to be performed within seven days of sample collection.

In order to accommodate field length limitations in processing the data summary forms, the laboratory did, in certain instances, abbreviate the sample identifier. The electronically formatted data provides for the full sample identifier. 


\section{TestAmerica}

THE LEADERIN ENVIRONMENTAL TESTING

\section{SOM01.2 Volatile Organics (Trace Level Water)}

A storage blank was prepared for volatile organics analysis, and stored in association with the storage of the samples. That storage blank, identified as VHBLK01, was carried through the holding period with the samples, and analyzed.

Each of the analyses associated with the sample set exhibited an acceptable internal standard performance. There was an acceptable recovery of each deuterated monitoring compound (DMC) in the analysis of the method blank associated with the analytical work, and in the analysis of the storage blank associated with the sample set. The analysis of the samples in this sample set did meet the technical acceptance criteria specific to DMC recoveries, although not all DMC recoveries were within the control range in each analysis. The technical acceptance criteria does provide for the recovery of up to three DMCs to fall outside of the control range in the analysis of field samples. The derived recoveries of 2-butanone- $d_{5}$ and 2 -hexanone- $d_{5}$ were elevated in the analysis of each of the field samples. Matrix spike and matrix spike duplicate analyses were not performed on samples in this sample set. The analysis of the method blank associated with the analytical work was free of contamination, as was the analysis of the storage blank. Present in the method blank and storage blank analyses was a non-target constituent that represented a compound that is related to the DMC formulation. The fact that the presence of this compound is not within the laboratory's control is at issue. The derived results for that compound have been qualified with an " $X$ " qualifier to reflect the source of the contamination.

The responses for each target analyte met the relative standard deviation criterion in the initial calibration. The response for each target analyte met the percent difference criterion in the continuing calibration check acquisition. The response for each target analyte met the 50.0 percent difference criterion in the closing calibration check acquisition.

The primary quantitation mass for methylcyclohexane that is specified in the Statement of Work is mass 83 . The laboratory did identify a contribution to mass 83 from 1,2-dichloropropane- $d_{6}$, one of the deuterated monitoring compounds (DMCs). The laboratory did change the primary quantitation mass assignment to mass 55 for the quantification of methylcyclohexane.

Manual integration was employed in deriving certain of the analytical results. The values that have been derived from manual integration are qualified on the quantitation reports. Extracted ion current profiles for each manual integration are included in the data package, and further documented in the Sample Preparation section of this submittal.

Any reference within this report to Severn Trent Laboratories, Inc. or STL, should be understood to refer to TestAmerica Laboratories, Inc. (formerly known as Severn Trent Laboratories, Inc.) The analytical results associated with the samples presented in this test report were generated under a quality system that adheres to requirements specified in the NELAC standard. Release of the data in this test report and any associated electronic deliverables is authorized by the Laboratory Director's designee as verified by the following signature. 


\section{TestAmerica}

THE LEADERIN ENVIRONMENTAL TESTING

If there are any questions regarding this submittal, please contact me at 802 660-1990.

Sincerely,

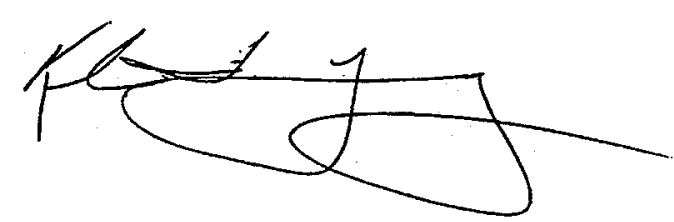

Kirk F. Young

Project Manager

KFY/hsf

Enclosure 


\section{TestAmerica Burlington Data Qualifier Definitions}

\section{$\underline{\text { Organic }}$}

$\mathrm{U}$ : Compound analyzed but not detected at a concentration above the reporting limit.

$\mathrm{J}: \quad$ Estimated value.

$\mathrm{N}$ : Indicates presumptive evidence of a compound. This flag is used only for tentatively identified compounds (TICs) where the identification of a compound is based on a mass spectral library search.

P: $\quad$ SW-846: The relative percent difference for detected concentrations between two GC columns is greater than $40 \%$. Unless otherwise specified the higher of the two values is reported on the Form $I$.

CLP SOW: Greater than $25 \%$ difference for detected concentrations between two $\mathrm{GC}$ columns. Unless otherwise specified the lower of the two values is reported on the Form I.

C: Pesticide result whose identification has been confirmed by GC/MS.

B: $\quad$ Analyte is found in the sample and the associated method blank. The flag is used for tentatively identified compounds as well as positively identified compounds.

E: Compounds whose concentrations exceed the upper limit of the calibration range of the instrument for that specific analysis.

D: Concentrations identified from analysis of the sample at a secondary dilution.

A: Tentatively identified compound is a suspected aldol condensation product.

$X, Y, Z$ : Laboratory defined flags that may be used alone or combined, as needed. If used, the description of the flag is defined in the project narrative.

\section{Inorganic/Metals}

$\mathrm{E}: \quad$ Reported value is estimated due to the presence of interference.

$\mathrm{N}$ : Matrix spike sample recovery is not within control limits.

* Duplicate sample analysis is not within control limits.

B: The result reported is less than the reporting limit but greater than the instrument detection limit.

U: Analyte was analyzed for but not detected above the reporting limit.

Method Codes:

P ICP-AES

MS ICP-MS

CV Cold Vapor AA

AS Semi-Automated Spectrophotometric 


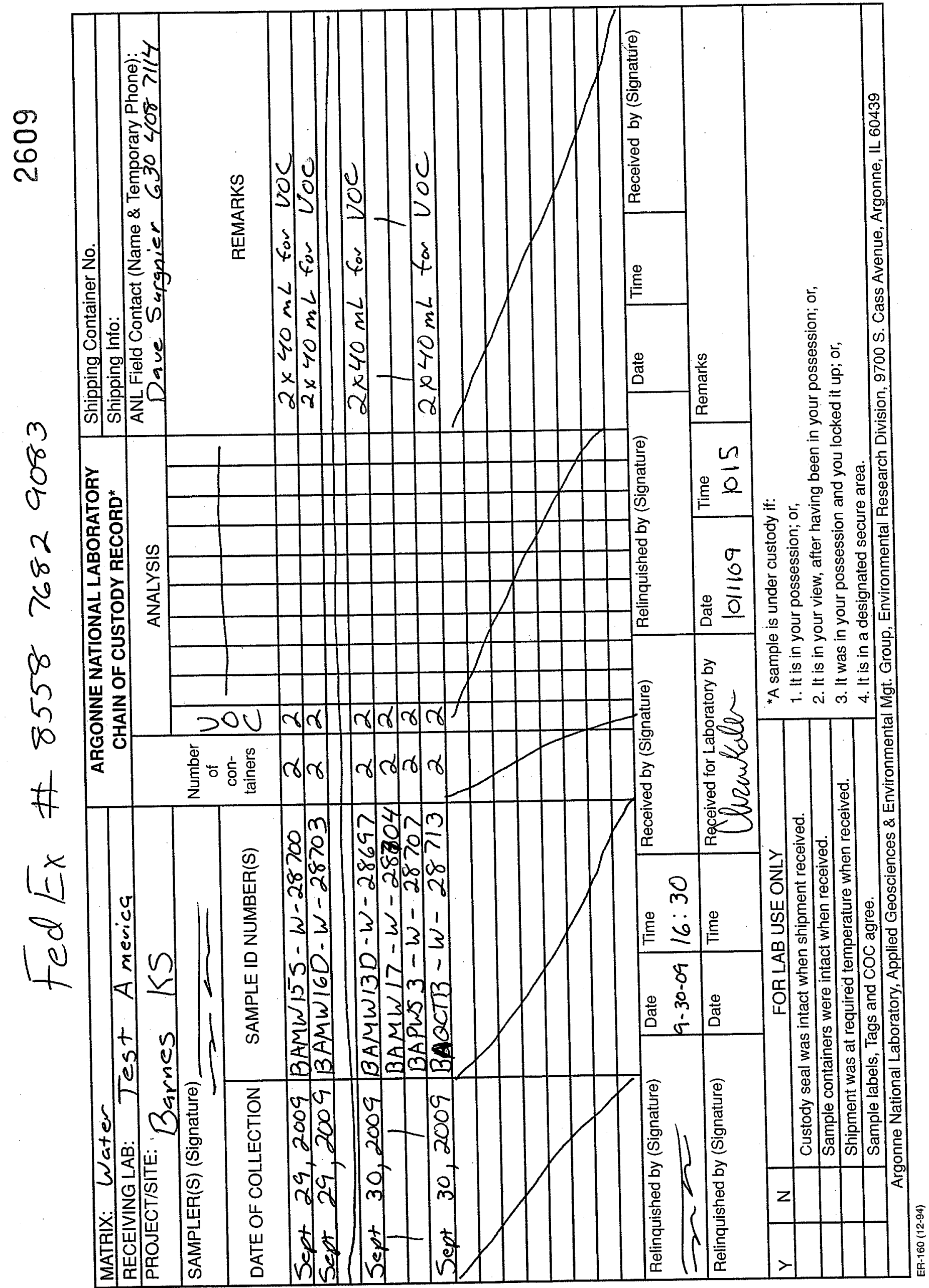




\section{TestAmerica

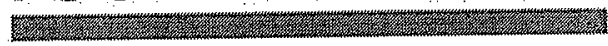 \\ THE LEADER IN ENVIRONMENTAL TESTING}

\section{Sample Data Summary - SOM01.2 Volatiles - Trace}




$$
\text { IA - FORM I VOA-1 }
$$

VOLATILE ORGANICS ANALYSIS DATA SHEET

EPA SAMPLE NO.

MW15SW28700

Lab Name: TESTAMERICA BURLINGTON

Contract: $8 \mathrm{E}-00302$

Lab Code: STLV Case No.: BARNES

Mod. Ref No.:

SDG NO.: 133894

Matrix: (SOII/SED/WATER) Water

Sample wt/vol: $25.0 \quad(\mathrm{~g} / \mathrm{mL}) \mathrm{mL}$

Lab Sample ID: 808349

Level: (TRACE/LOW/MED) TRACE

Lab File ID: 808349

\% Moisture: not dec.

Date Received: 10/01/2009

Date Analyzed: 10/06/2009

GC Column: DB-624

ID : 0.53

(mm)

Dilution Factor: 1.0

Soil Extract Volume:

(uI) Soil Aliquot Volume:

Purge Volume: 25.0

(mL)

\begin{tabular}{|c|c|c|c|}
\hline CAS NO. & COMPOUND & $\begin{array}{l}\text { CONCENTRATION UNITS: } \\
(\mathrm{ug} / \mathrm{I} \text { or } \mathrm{ug} / \mathrm{kg}) \mathrm{ug} / \mathrm{L}\end{array}$ & $\mathrm{Q}$ \\
\hline$===========$ & 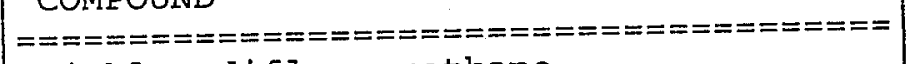 & 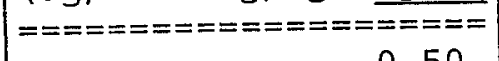 & $========$ \\
\hline $75-71-8$ & Dichlorodifluoromethane & 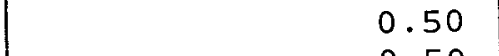 & $\mathrm{U}$ \\
\hline $74-87-3$ & Chloromethane & 0.50 & $\mathrm{U}$ \\
\hline $75-01-4$ & Vinyl chloride & 0.50 & $\mathrm{U}$ \\
\hline $74-83-9$ & Bromomethane & 0.50 & $\mathrm{U}$ \\
\hline $75-00-3$ & Chloroethane & 0.50 & $\mathrm{U}$ \\
\hline $75-69-4$ & Trichlorofluoromethane & 0.50 & $\mathrm{U}$ \\
\hline $75-35-4$ & 1,1-Dichloroethene & 0.50 & $\mathrm{U}$ \\
\hline $76-13-1$ & $1,1,2$-Trichloro-1,2,2-trifluoroethane & 0.50 & $\mathrm{U}$ \\
\hline $67-64-1$ & Acetone & 5.0 & $\mathrm{U}$ \\
\hline $75-15-0$ & Carbon disulfide & 0.50 & $\mathrm{U}$ \\
\hline $79-20-9$ & Methyl acetate & 0.50 & $\mathrm{U}$ \\
\hline $75-09-2$ & Methylene chloride & 0.50 & $\mathrm{U}$ \\
\hline $156-60-5$ & trans-1,2-Dichloroethene & 0.50 & $\mathrm{U}$ \\
\hline $1634-04-4$ & Methyl tert-butyl ether & $0: 50$ & $\mathrm{U}$ \\
\hline $75-34-3$ & 1,1-Dichloroethane & 0.50 & $\mathrm{U}$ \\
\hline $156-59-2$ & Cis-1,2-Dichloroethene & 0.50 & $\mathrm{U}$ \\
\hline $78-93-3$ & 2-Butanone & 5.0 & $\mathrm{U}$ \\
\hline $74-97-5$ & Bromochloromethane & 0.50 & $\mathrm{U}$ \\
\hline $67-66-3$ & Chloroform & 0.23 & $\mathrm{~J}$ \\
\hline $71-55-6$ & 1,1,1-Trichloroethane & 0.50 & $\mathrm{U}$ \\
\hline $110-82-7$ & $\begin{array}{l}1,1,1-1 \\
\text { Cyclohexane }\end{array}$ & 0.50 & $\mathrm{U}$ \\
\hline $56-23-5$ & Carbon tetrachloride & 2.1 & \\
\hline $71-43-2$ & Benzene & 0.50 & $\overline{\mathrm{U}}$ \\
\hline $107-06-2$ & 1,2-Dichloroethane & 0.50 & $\mathrm{U}$ \\
\hline
\end{tabular}

Report 1,4-Dioxane for Low-Medium VOA analysis only 
Lab Name: TESTAMERICA BURLINGTON

Lab Code: STLV Case No.: BARNES

Matrix: (SOIL/SED/WATER) water

Sample wt/vol: 25.0

$(g / m L) \mathrm{mL}$

Level: (TRACE/LOW/MED) TRACE

$\%$ Moisture: not dec.

GC Column: DB-624 ID: 0.53 (mm)

Soil Extract Volume:

Purge Volume: 25.0
Contract: $8 \mathrm{E}-00302$

Mod. Ref No.:

SDG No.: 133894
Lab Sample ID: 808349

Lab File ID: 808349

Date Received: 10/01/2009

Date Analyzed: 10/06/2009

Dilution Factor: 1.0

Soil Aliquot Volume:

\begin{tabular}{|c|c|c|c|}
\hline $\begin{array}{c}\text { CAS NO. } \\
=========== \\
79-01-6 \\
108-87-2 \\
78-87-5 \\
75-27-4 \\
10061-01-5 \\
108-10-1 \\
108-88-3 \\
10061-02-6 \\
79-00-5 \\
127-18-4 \\
591-78-6 \\
124-48-1 \\
106-93-4 \\
108-90-7 \\
100-41-4 \\
95-47-6 \\
179601-23-1 \\
100-42-5 \\
75-25-2 \\
98-82-8 \\
79-34-5 \\
541-73-1 \\
106-46-7 \\
95-50-1 \\
96-12-8 \\
120-82-1 \\
87-61-6\end{array}$ & 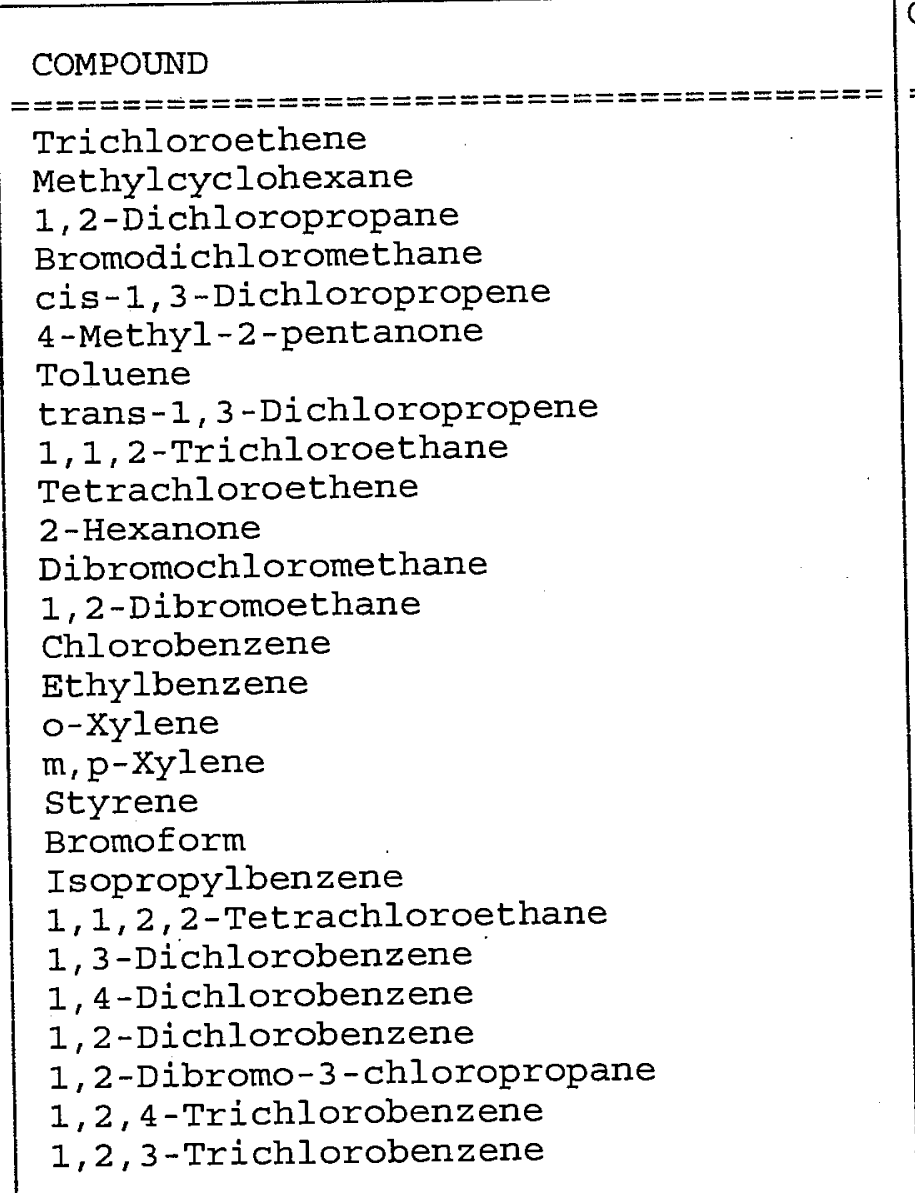 & $\begin{array}{cc}\text { CONCENTRATION UNITS: } \\
\text { (ug/L or ug/kg) } & \text { ug/L } \\
================= \\
0.50 \\
0.50 \\
0.50 \\
0.50 \\
0.50 \\
5.0 \\
0.50 \\
0.50 \\
0.50 \\
0.50 \\
5.0 \\
0.50 \\
0.50 \\
0.50 \\
0.50 \\
0.50 \\
0.50 \\
0.50 \\
0.50 \\
0.50 \\
0.50 \\
0.50 \\
0.50 \\
0.50 \\
0.50 \\
0.50 \\
0.50\end{array}$ & $\begin{array}{l}========== \\
U \\
U \\
U \\
U \\
U \\
U \\
U \\
U \\
U \\
U \\
U \\
U \\
U \\
U \\
U \\
U \\
U \\
U \\
U \\
U \\
U \\
U \\
U \\
U \\
U \\
U \\
U\end{array}$ \\
\hline
\end{tabular}


$1 A$ - FORM I VOA-1

VOLATILE ORGANICS ANALYSIS DATA SHEET

Lab Name: TESTAMERICA BURIINGTON

Contract: $8 \mathrm{E}-00302$

Lab Code: STLV Case No.: BARNES

Mod. Ref No.:

SDG No.: 133894

Matrix: (SOIL/SED/WATER) Water

Lab Sample ID: 808350

Sample wt/vol: $25.0 \quad(\mathrm{~g} / \mathrm{mL}) \mathrm{mL}$

Lab File ID: 808350

Level: (TRACE/LOW/MED) TRACE

Date Received: 10/01/2009

$\div$ Moisture: not dec.

Date Analyzed: 10/06/2009

GC Column: DB-624

ID $: 0.53$

(mm)

Dilution Factor: 1.0

Soil Extract Volume:

(uL) Soil Aliquot Volume:

Purge Volume: 25.0

(mL)

\begin{tabular}{|c|c|c|c|}
\hline CAS NO. & 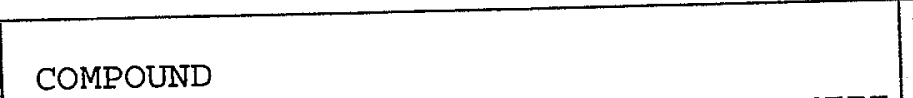 & $\begin{array}{l}\text { CONCENTRATION UNITS: } \\
(\mathrm{ug} / \mathrm{L} \text { or } \mathrm{ug} / \mathrm{kg}) \text { ug } / \mathrm{L}\end{array}$ & $\underset{2}{Q}======$ \\
\hline$===========$ & 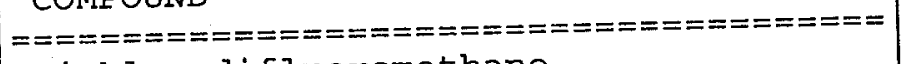 & 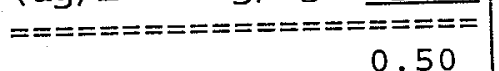 & $\begin{array}{c}======= \\
\mathrm{U}\end{array}$ \\
\hline $75-71-8$ & Dichlorodifluoromethane & $\begin{array}{l}0.50 \\
0.50\end{array}$ & U \\
\hline $74-87-3$ & Chloromethane & 0.50 & $\mathrm{U}$ \\
\hline $75-01-4$ & Vinyl chloride & 0.50 & $\mathrm{U}$ \\
\hline $74-83-9$ & Bromomethane & 0.50 & $\mathrm{U}$ \\
\hline $75-00-3$ & Chloroethane & 0.50 & $\mathrm{U}$ \\
\hline $75-69-4$ & Trichlorofluoromethane & 0.50 & $U$ \\
\hline $75-35-4$ & 1,1-Dichloroethene & 0.50 & $\mathrm{U}$ \\
\hline $76-13-1$ & $\begin{array}{l}1,1,2 \text {-Trichloro- } 1,2,2 \text {-trifluoroethane } \\
\text { Acetone }\end{array}$ & 5.0 & $U$ \\
\hline $67-64-1$ & $\begin{array}{l}\text { Acetone } \\
\text { Carbon disulfide }\end{array}$ & 0.50 & $\mathrm{U}$ \\
\hline $75-15-0$ & $\begin{array}{l}\text { Carbon disulfide } \\
\text { Methyl acetate }\end{array}$ & 0.50 & $\mathrm{U}$ \\
\hline $79-20-9$ & Methyl acetate & 0.50 & $\mathrm{U}$ \\
\hline $75-09-2$ & Methylene chloride & 0.50 & $\mathrm{U}$ \\
\hline $156-60-5$ & $\begin{array}{l}\text { trans-1,2-Dichloroethene } \\
\text { Methyl tert-butyl ether }\end{array}$ & 0.50 & $\mathrm{U}$ \\
\hline $1634-04-4$ & Methyl tert-butyl ether & 0.50 & $\mathrm{U}$ \\
\hline $75-34-3$ & 1,1-Dichloroethane & 0.50 & $\mathrm{U}$ \\
\hline $156-59-2$ & cis-1,2-Dichloroethene & 5.0 & $\mathrm{U}$ \\
\hline $78-93-3$ & 2-Butanone & 0.50 & $\mathrm{U}$ \\
\hline $74-97-5$ & Bromochloromethane & 0.50 & $U$ \\
\hline $67-66-3$ & Chloroform & 0.50 & U \\
\hline $71-55-6$ & $1,1,1$-Trichloroethane & 0.50 & $\mathrm{U}$ \\
\hline $110-82-7$ & Cyclohexane & 0.50 & $\mathrm{U}$ \\
\hline $56-23-5$ & Carbon tetrachloride & 0.50 & $\mathrm{U}$ \\
\hline $71-43-2$ & $\begin{array}{l}\text { Benzene } \\
1,2 \text {-Dichloroethane }\end{array}$ & 0.50 & $\mathrm{U}$ \\
\hline $107-06-2$ & 1,2-Dichloroethane & & \\
\hline
\end{tabular}

Report 1,4-Dioxane for Low-Medium VOA analysis only 


\section{$1 B$ - FORM I VOA-2 \\ VOLATILE ORGANICS ANALYSIS DATA SHEET}

Lab Name: TESTAMERICA BURLINGTON

Lab Code: STLV Case No.: BARNES

Matrix: (SOIL/SED/WATER) Water

Sample wt/vol: $25.0 \quad(\mathrm{~g} / \mathrm{mL}) \mathrm{mL}$

Level: (TRACE/LOW/MED) TRACE

$\%$ Moisture: not dec.

GC Column: DB-624

ID $: 0.53$

Soil Extract Volume:

Purge Volume: 25.0
Contract: $8 \mathrm{E}-00302$

Mod. Ref No.:
SDG NO.: 133894
Lab Sample ID: 808350

Lab File ID: 808350

Date Received: 10/01/2009

Date Analyzed: 10/06/2009

Dilution Factor: 1.0

Soil Aliquot Volume:

(mL)

\begin{tabular}{|c|c|c|c|}
\hline CAS NO. & COMPOUND & $\begin{array}{l}\text { CONCENTRATION UNITS: } \\
(\mathrm{ug} / \mathrm{L} \text { or } \mathrm{ug} / \mathrm{kg}) \mathrm{ug} / \mathrm{L}\end{array}$ & $Q$ \\
\hline$===========$ & 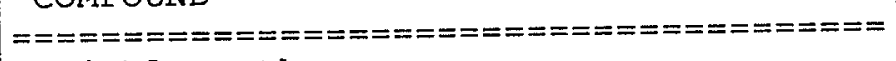 & 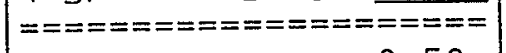 & $========$ \\
\hline $\begin{array}{r}79-01-6 \\
108-87-2\end{array}$ & Trichloroethene & 0.50 & $\mathrm{U}$ \\
\hline $108-87-2$ & Methylcyclohexane & 0.50 & $\mathrm{U}$ \\
\hline $78-87-5$ & 1,2-Dichloropropane & 0.50 & $\mathrm{U}$ \\
\hline $75-27-4$ & Bromodichloromethane & 0.50 & U \\
\hline $10061-01-5$ & cis-1,3-Dichloropropene & 0.50 & U \\
\hline $108-10-1$ & 4 -Methyl-2-pentanone & 5.0 & $\mathrm{U}$ \\
\hline $108-88-3$ & Toluene & 0.50 & $\mathrm{U}$ \\
\hline $10061-02-6$ & trans-1,3-Dichloropropene & 0.50 & $\mathrm{U}$ \\
\hline $79-00-5$ & $1,1,2$-Trichloroethane & 0.50 & U \\
\hline $127-18-4$ & Tetrachloroethene & 0.50 & $\mathrm{U}$ \\
\hline $591-78-6$ & 2 -Hexanone & 5.0 & U \\
\hline $124-48-1$ & Dibromochloromethane & 0.50 & $\mathrm{U}$ \\
\hline $106-93-4$ & 1,2-Dibromoethane & 0.50 & $\mathrm{U}$ \\
\hline $108-90-7$ & Chlorobenzene & 0.50 & $\mathrm{U}$ \\
\hline $100-41-4$ & Ethylbenzene & 0.50 & $\mathrm{U}$ \\
\hline $95-47-6$ & o-Xylene & 0.50 & $\mathrm{U}$ \\
\hline $179601-23-1$ & $\mathrm{~m}, \mathrm{p}$-Xylene & 0.50 & $\mathrm{U}$ \\
\hline $100-42-5$ & styrene & 0.50 & $\mathrm{U}$ \\
\hline $75-25-2$ & Bromoform & 0.50 & $\mathrm{U}$ \\
\hline $98-82-8$ & Isopropylbenzene & 0.50 & $\mathrm{U}$ \\
\hline $79-34-5$ & $1,1,2,2$-Tetrachloroethane & 0.50 & $\mathrm{U}$ \\
\hline $541-73-1$ & 1,3-Dichlorobenzene & 0.50 & U \\
\hline $106-46-7$ & 1,4 -Dichlorobenzene & 0.50 & $\mathrm{U}$ \\
\hline $95-50-1$ & 1,2 -Dichlorobenzene & 0.50 & $\mathrm{U}$ \\
\hline $96-12-8$ & 1,2-Dibromo-3-chloropropane & 0.50 & $\mathrm{U}$ \\
\hline $120-82-1$ & $1,2,4$-Trichlorobenzene & 0.50 & $\mathrm{U}$ \\
\hline $87-61-6$ & $1,2,3$-Trichlorobenzene & 0.50 & $\mathrm{U}$ \\
\hline
\end{tabular}


$1 A$ - FORM I VOA-1

VOLATILE ORGANICS ANAIYSIS DATA SHEET

Lab Name: TESTAMERICA BURIINGTON

Lab code: STLV Case No.: BARNES

Matrix: (SOIL/SED/WATER) Water

Sample wt/vol: 25.0

$(\mathrm{g} / \mathrm{mL}) \mathrm{mL}$

Level: (TRACE/LOW/MED) TRACE

\% Moisture: not dec.

GC Column: DB-624

Soil Extract Volume:

ID: $0.53 \quad(\mathrm{~mm})$

(UI)

Contract: $8 \mathrm{E}-00302$

Mod. Ref No.:
Lab Sample ID: 808351

Lab File ID: 808351

Date Received: 10/01/2009

Date Analyzed: 10/06/2009

Dilution Factor: 1.0

Soil Aliquot Volume:

(uL)

Purge Volume: 25.0

(mI)

\begin{tabular}{|c|c|c|c|}
\hline CAS NO. & COMPOUND & $\begin{array}{l}\text { CONCENTRATION UNITS: } \\
(\mathrm{ug} / \mathrm{L} \text { or } \mathrm{ug} / \mathrm{kg}) \text { ug/L }\end{array}$ & Q \\
\hline$==========$ & 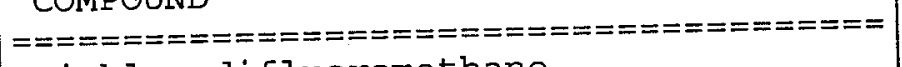 & 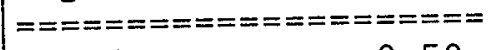 & $========$ \\
\hline $75-71-8$ & Dichlorodifluoromethane & 0.50 & $U$ \\
\hline $74-87-3$ & Chloromethane & 0.50 & $\mathrm{U}$ \\
\hline $75-01-4$ & Vinyl chloride & 0.50 & $\begin{array}{l}\mathrm{U} \\
\mathrm{U}\end{array}$ \\
\hline $74-83-9$ & Bromomethane & $\begin{array}{l}0.50 \\
0.50\end{array}$ & $\begin{array}{l}\mathrm{U} \\
\mathrm{U}\end{array}$ \\
\hline $75-00-3$ & Chloroethane & 0.50 & $\mathrm{U}$ \\
\hline $75-69-4$ & Trichlorofluoromethane & 0.50 & $\mathrm{U}$ \\
\hline $75-35-4$ & 1,1-Dichloroethene & 0.50 & $\mathrm{U}$ \\
\hline $76-13-1$ & $1,1,2$-Trichloro-1,2,2-trifluoroethane & 5.0 & $\mathrm{U}$ \\
\hline $67-64-1$ & Acetone & 0.50 & $\mathrm{U}$ \\
\hline $75-15-0$ & Carbon disulfide & 0.50 & U \\
\hline $79-20-9$ & Methyl acetate & 0.50 & U \\
\hline $75-09-2$ & Methylene chloride & 0.50 & U \\
\hline $156-60-5$ & trans-1,2-Dichloroethene & 0.50 & $\mathrm{U}$ \\
\hline $1634-04-4$ & Methyl tert-butyl ether & 0.50 & $\mathrm{U}$ \\
\hline $75-34-3$ & 1,1-Dichloroethane & 0.50 & U \\
\hline $156-59-2$ & $\begin{array}{l}\text { Cis-1,2-Dichloroethene } \\
\text { 2-Butanone }\end{array}$ & 5.0 & U \\
\hline $78-93-3$ & $\begin{array}{l}\text { 2-Butanone } \\
\text { Bromochloromethane }\end{array}$ & 0.50 & $\mathrm{U}$ \\
\hline $74-97-5$ & $\begin{array}{l}\text { Bromochloromethane } \\
\text { Chloroform }\end{array}$ & 0.97 & \\
\hline $67-66-3$ & $\begin{array}{l}\text { Chloroform } \\
1,1,1 \text {-Trichloroethane }\end{array}$ & 0.50 & $\bar{U}$ \\
\hline $71-55-6$ & $\begin{array}{l}1,1,1 \text {-Trichloroethane } \\
\text { Cyclohexane }\end{array}$ & 0.50 & $\mathrm{U}$ \\
\hline $110-82-7$ & $\begin{array}{l}\text { Cyclohexane } \\
\text { Carbon tetrachloride }\end{array}$ & 6.1 & \\
\hline $56-23-5$ & $\begin{array}{l}\text { Carbon tetrachloride } \\
\text { Benzene }\end{array}$ & 0.50 & $\overline{\mathrm{U}}$ \\
\hline $71-43-2$ & $\begin{array}{l}\text { Benzene } \\
\text { 1,2-Dichloroethane }\end{array}$ & 0.50 & U \\
\hline $107-06-2$ & 1,2-Dichloroethane & & \\
\hline
\end{tabular}

Report 1,4-Dioxane for Low-Medium VOA analysis only 
$1 B$ - FORM I VOA-2

VOLATILE ORGANICS ANALYSIS DATA SHEET
EPA SAMPLE NO.

MW13DW28697

Lab Name: TESTAMERICA BURIINGTON

Contract: 8E-00302

Lab Code: STLV Case No.: BARNES Mod. Ref No.:

SDG NO.: 133894

Lab Sample ID: 808351

Matrix: (SOIL/SED/WATER) Water

Lab File ID: 808351

Sample wt/vol: 25.0

$(\mathrm{g} / \mathrm{mL}) \mathrm{mI}$

Level: (TRACE/LOW/MED) TRACE

Date Received: 10/01/2009

\% Moisture: not dec.

Date Analyzed: 10/06/2009

GC Column: DB-624

ID : 0.53

(mm)

Dilution Factor: 1.0

Soil Extract Volume:

(uL) Soil Aliquot Volume:

Purge volume: 25.0

(mL)

\begin{tabular}{|c|c|c|c|}
\hline CAS NO. & (1) & $\begin{array}{l}\text { CONCENTRATION UNITS: } \\
(\mathrm{ug} / \mathrm{L} \text { or } \mathrm{ug} / \mathrm{kg}) \mathrm{ug} / \mathrm{L}\end{array}$ & $=\stackrel{\mathrm{Q}}{=======}$ \\
\hline $\begin{array}{c}========== \\
79-01-6\end{array}$ & 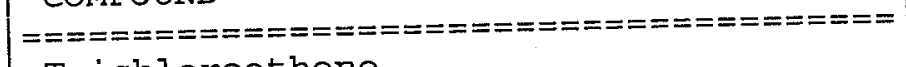 & $\begin{aligned}=================== \\
0.50\end{aligned}$ & $\begin{array}{c}======= \\
\mathrm{U}\end{array}$ \\
\hline $\begin{array}{r}79-01-6 \\
108-87-2\end{array}$ & Trichloroethene & 0.50 & $\mathrm{U}$ \\
\hline $\begin{array}{r}108-87-2 \\
78-87-5\end{array}$ & Methylcyclohexane & 0.50 & U \\
\hline $\begin{array}{l}78-87-5 \\
75-27-4\end{array}$ & 1,2-Dichloropropane & 0.50 & U \\
\hline $\begin{array}{r}75-27-4 \\
10061-01-5\end{array}$ & Bromodichloromethane & 0.50 & $\mathrm{U}$ \\
\hline $\begin{array}{r}10061-01-5 \\
108-10-1\end{array}$ & cis-1,3-Dichloropropene & 5.0 & $\mathrm{U}$ \\
\hline $\begin{array}{l}108-10-1 \\
108-88-3\end{array}$ & 4-Methyl-2-pentanone & 0.50 & U \\
\hline $\begin{array}{r}108-88-3 \\
10061-02-6\end{array}$ & Toluene & 0.50 & $\mathrm{U}$ \\
\hline $\begin{array}{r}10061-02-6 \\
79-00-5\end{array}$ & $\begin{array}{l}\text { trans-1,3-Dichloropropene } \\
1,1,2 \text {-Trichloroethane }\end{array}$ & 0.50 & U \\
\hline $\begin{array}{r}79-00-5 \\
127-18-4\end{array}$ & $\begin{array}{l}\text { 1,1,2-Trichloroethane } \\
\text { Tetrachloroethene }\end{array}$ & 0.50 & U \\
\hline $\begin{array}{l}127-18-4 \\
591-78-6\end{array}$ & $\begin{array}{l}\text { Tetrachloroethene } \\
\text { 2-Hexanone }\end{array}$ & 5.0 & $\mathrm{U}$ \\
\hline $\begin{array}{l}591-78-6 \\
124-48-1\end{array}$ & 2-Hexanone & 0.50 & U \\
\hline $\begin{array}{l}124-48-1 \\
106-93-4\end{array}$ & $\begin{array}{l}\text { Dibromochloromethane } \\
\text { 2-Dibromoethane }\end{array}$ & 0.50 & U \\
\hline $\begin{array}{l}106-93-4 \\
108-90-7\end{array}$ & $\begin{array}{l}\text { 1,2-Dibromoethane } \\
\text { Chlorobenzene }\end{array}$ & 0.50 & U \\
\hline $108-90-7$ & $\begin{array}{l}\text { Chlorobenzene } \\
\text { Ethylbenzene }\end{array}$ & 0.50 & $\mathrm{U}$ \\
\hline $95-47-6$ & o-Xylene & 0.50 & U \\
\hline $179601-23-1$ & $\begin{array}{l}\text { m, p-xylene } \\
\text { styrene }\end{array}$ & 0.50 & U \\
\hline $100-42-5$ & $\begin{array}{l}\text { Styrene } \\
\text { Bromoform }\end{array}$ & 0.50 & U \\
\hline $75-25-2$ & Bromoform & 0.50 & U \\
\hline $98-82-8$ & Isopropylbenzene & 0.50 & U \\
\hline $79-34-5$ & $\begin{array}{l}1,1,2,2-\text { Tetrachloroethane } \\
3\end{array}$ & 0.50 & $\mathrm{U}$ \\
\hline $541-73-1$ & $\begin{array}{l}\text { 1,3-Dichlorobenzene } \\
\text { 4-Dichlorobenzene }\end{array}$ & 0.50 & $\mathrm{U}$ \\
\hline $106-46-7$ & $\begin{array}{l}\text { 1,4-Dichlorobenzene } \\
\text { 1,-Dichlorobenzene }\end{array}$ & 0.50 & U \\
\hline $95-50-1$ & $\begin{array}{l}\text { 1,2-Dichlorobenzene } \\
\text { 1,2-Dibromo-3-chloropropane }\end{array}$ & 0.50 & U \\
\hline $96-12-8$ & $\begin{array}{l}\text { 1,2-Dibromo-3-chloropropane } \\
\text { - }\end{array}$ & 0.50 & $\mathrm{U}$ \\
\hline $\begin{array}{r}120-82-1 \\
87-61-6\end{array}$ & $\begin{array}{l}1,2,4 \text {-Trichlorobenzene } \\
1,2,3 \text {-Trichlorobenzene }\end{array}$ & 0.50 & $\mathrm{U}$ \\
\hline & & & \\
\hline
\end{tabular}


$1 A$ - FORM I VOA-1

VOLATILE ORGANICS ANALYSIS DATA SHEET
EPA SAMPLE NO.

MW17W28704
Lab Name: TESTAMERICA BURLINGTON

Iab Code: STLV Case No.: BARNES

Matrix: (SOIL/SED/WATER) Water

Sample wt/vol: 25.0

$(\mathrm{g} / \mathrm{mI}) \mathrm{mI}$

Level: (TRACE/LOW/MED) TRACE

\% Moisture: not dec.

GC Column: DB-624

ID $: 0.53$

Soil Extract Volume:

Purge Volume: 25.0
Contract: $8 E-00302$

Mod. Ref No.:
Lab Sample ID: 808352

Lab File ID: 808352

Date Received: 10/01/2009

Date Analyzed: 10/06/2009

Dilution Factor: 1.0

Soil Aliquot Volume:

\begin{tabular}{|c|c|c|c|}
\hline $\begin{array}{l}\text { CAS NO. } \\
========= \\
75-71-8 \\
74-87-3 \\
75-01-4 \\
74-83-9 \\
75-00-3 \\
75-69-4 \\
75-35-4 \\
76-13-1 \\
67-64-1 \\
75-15-0 \\
79-20-9 \\
75-09-2 \\
156-60-5 \\
1634-04-4 \\
75-34-3 \\
156-59-2 \\
78-93-3 \\
74-97-5 \\
67-66-3 \\
71-55-6 \\
110-82-7 \\
56-23-5 \\
71-43-2 \\
107-06-2\end{array}$ & $\begin{array}{l}\text { COMPOUND } \\
=========================== \\
\text { Dichlorodifluoromethane } \\
\text { Chloromethane } \\
\text { Vinyl chloride } \\
\text { Bromomethane } \\
\text { Chloroethane } \\
\text { Trichlorofluoromethane } \\
\text { 1, 1-Dichloroethene } \\
\text { 1, } 1,2-\text { Trichloro-1, } 2,2-t r i f l u o r o e t h a n e \\
\text { Acetone } \\
\text { Carbon disulfide } \\
\text { Methyl acetate } \\
\text { Methylene chloride } \\
\text { trans-1,2-Dichloroethene } \\
\text { Methyl tert-butyl ether } \\
1,1-D i c h l o r o e t h a n e \\
\text { cis-1,2-Dichloroethene } \\
2-\text { Butanone } \\
\text { Bromochloromethane } \\
\text { Chloroform } \\
1,1,1-\text { Trichloroethane } \\
\text { Cyclohexane } \\
\text { Carbon tetrachloride } \\
\text { Benzene } \\
1,2-D i c h l o r o e t h a n e\end{array}$ & \begin{tabular}{|cc} 
CONCENTRATION UNITS: \\
(ug/L Or ug/kg) & ug $/ \mathrm{L}$ \\
$=============$ \\
0.50 \\
0.50 \\
0.50 \\
0.50 \\
0.50 \\
0.50 \\
0.50 \\
0.50 \\
5.0 \\
0.50 \\
0.50 \\
0.50 \\
0.50 \\
0.50 \\
0.50 \\
0.50 \\
5.0 \\
0.50 \\
0.50 \\
0.50 \\
0.50 \\
0.71 \\
0.50 \\
0.50
\end{tabular} & $\begin{array}{l}======= \\
U \\
U \\
U \\
U \\
U \\
U \\
U \\
U \\
U \\
U \\
U \\
U \\
U \\
U \\
U \\
U \\
U \\
U \\
U \\
U \\
U \\
U \\
U\end{array}$ \\
\hline
\end{tabular}

Report 1,4-Dioxane for Low-Medium VOA analysis only 
Lab Name: TESTAMERICA BURLINGTON

Lab code: STLV Case No.: BARNES Mod. Ref No.:
Contract : $8 \mathrm{E}-00302$

SDG No.: 133894

\section{Matrix: (SOIL/SED/WATER) water}

Sample wt/vol: 25.0

$(\mathrm{g} / \mathrm{mL}) \mathrm{mL}$

Level: (TRACE/LOW/MED) TRACE

\% Moisture: not dec.

GC Column: DB-624

ID : 0.53

Soil Extract Volume:

Purge Volume: 25.0
Lab Sample ID: 808352

Lab File ID: 808352

Date Received: 10/01/2009

Date Analyzed: 10/06/2009

Dilution Factor: 1.0

Soil Aliquot Volume:

(m工)

\begin{tabular}{|c|c|c|c|}
\hline \begin{tabular}{|} 
CAS NO. \\
$=========$ \\
$79-01-6$ \\
$108-87-2$ \\
$78-87-5$ \\
$75-27-4$ \\
$10061-01-5$ \\
$108-10-1$ \\
$108-88-3$ \\
$10061-02-6$ \\
$79-00-5$ \\
$127-18-4$ \\
$591-78-6$ \\
$124-48-1$ \\
$106-93-4$ \\
$108-90-7$ \\
$100-41-4$ \\
$95-47-6$ \\
$179601-23-1$ \\
$100-42-5$ \\
$75-25-2$ \\
$98-82-8$ \\
$79-34-5$ \\
$541-73-1$ \\
$106-46-7$ \\
$95-50-1$ \\
$96-12-8$ \\
$120-82-1$ \\
$87-61-6$
\end{tabular} & 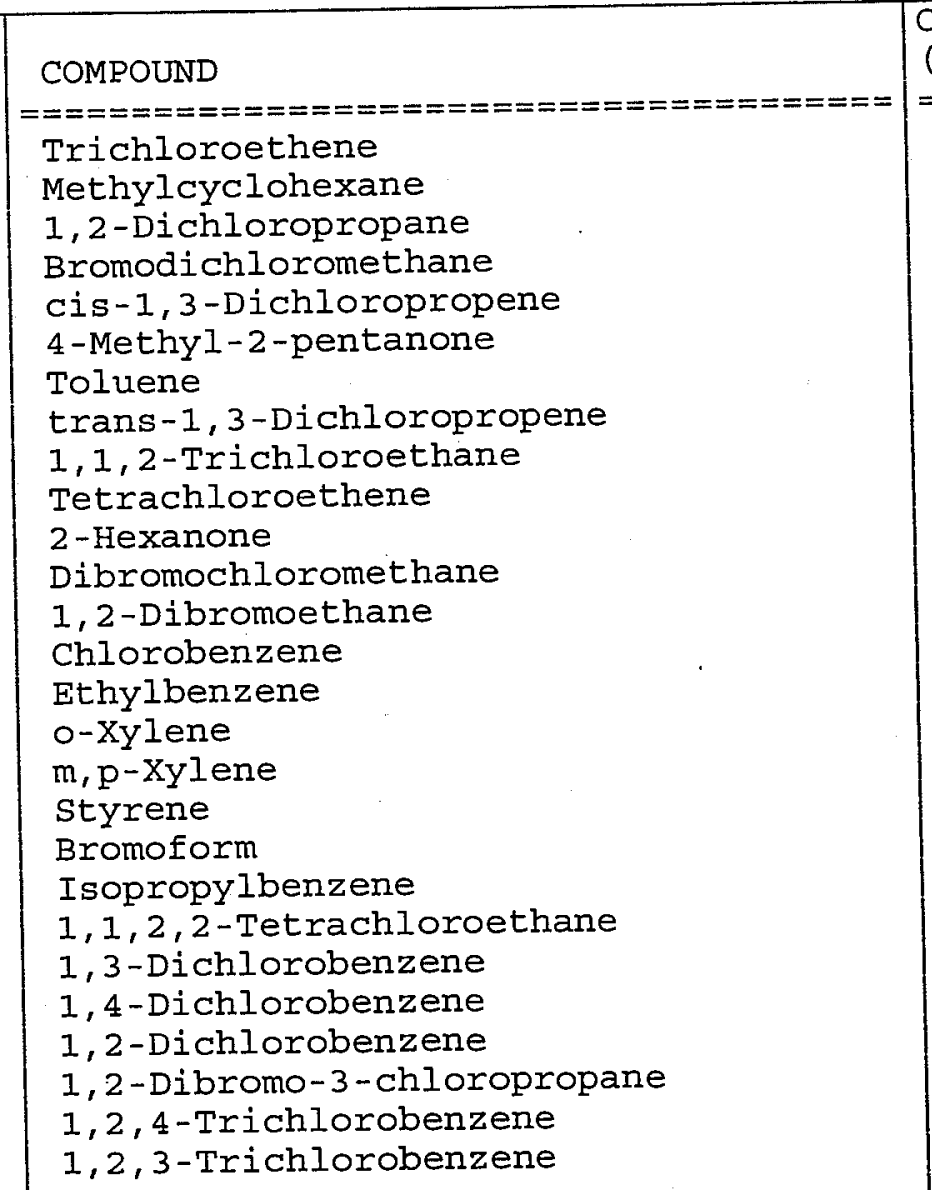 & \begin{tabular}{|cc} 
CONCENTRATION UNITS : \\
(ug/L or ug/kg) & ug/I \\
$=================$ \\
0.50 \\
0.50 \\
0.50 \\
0.50 \\
0.50 \\
5.0 \\
0.50 \\
0.50 \\
0.50 \\
0.50 \\
5.0 \\
0.50 \\
0.50 \\
0.50 \\
0.50 \\
0.50 \\
0.50 \\
0.50 \\
0.50 \\
0.50 \\
0.50 \\
0.50 \\
0.50 \\
0.50 \\
0.50 \\
0.50 \\
0.50 \\
\end{tabular} & \begin{tabular}{|l}
$========$ \\
$U$ \\
$U$ \\
$U$ \\
$U$ \\
$U$ \\
$U$ \\
$U$ \\
$U$ \\
$U$ \\
$U$ \\
$U$ \\
$U$ \\
$U$ \\
$U$ \\
$U$ \\
$U$ \\
$U$ \\
$U$ \\
$U$ \\
$U$ \\
$U$ \\
$U$ \\
$U$ \\
$U$ \\
$U$ \\
$U$ \\
$U$
\end{tabular} \\
\hline
\end{tabular}


$1 A$ - FORM I VOA-1

VOLATILE ORGANICS ANALYSIS DATA SHEET
EPA SAMPLE NO.

PWS $3 W 28707$
Lab Name: TESTAMERICA BURIINGTON

Lab Code: STIV Case No.: BARNES

Matrix: (SOIL/SED/WATER) water

Sample wt/vol: 25.0

$(\mathrm{g} / \mathrm{mL}) \mathrm{mL}$

Level: (TRACE/LOW/MED) TRACE

$\%$ Moisture: not dec.

GC Column: DB-624

ID : 0.53

Soil Extract Volume:

Purge Volume: 25.0
Contract: $8 \mathrm{E}-00302$

Mod. Ref No.:

SDG NO.: 133894
Lab Sample ID: 808353

Lab File ID: 808353

Date Received: 10/01/2009

Date Analyzed: 10/06/2009

Dilution Factor: 1.0

Soil Aliquot volume:

\begin{tabular}{|c|c|c|c|}
\hline $\begin{array}{c}\text { CAS NO. } \\
========== \\
75-71-8 \\
74-87-3 \\
75-01-4 \\
74-83-9 \\
75-00-3 \\
75-69-4 \\
75-35-4 \\
76-13-1 \\
67-64-1 \\
75-15-0 \\
79-20-9 \\
75-09-2 \\
156-60-5 \\
1634-04-4 \\
75-34-3 \\
156-59-2 \\
78-93-3 \\
74-97-5 \\
67-66-3 \\
71-55-6 \\
110-82-7 \\
56-23-5 \\
71-43-2 \\
107-06-2 \\
707\end{array}$ & 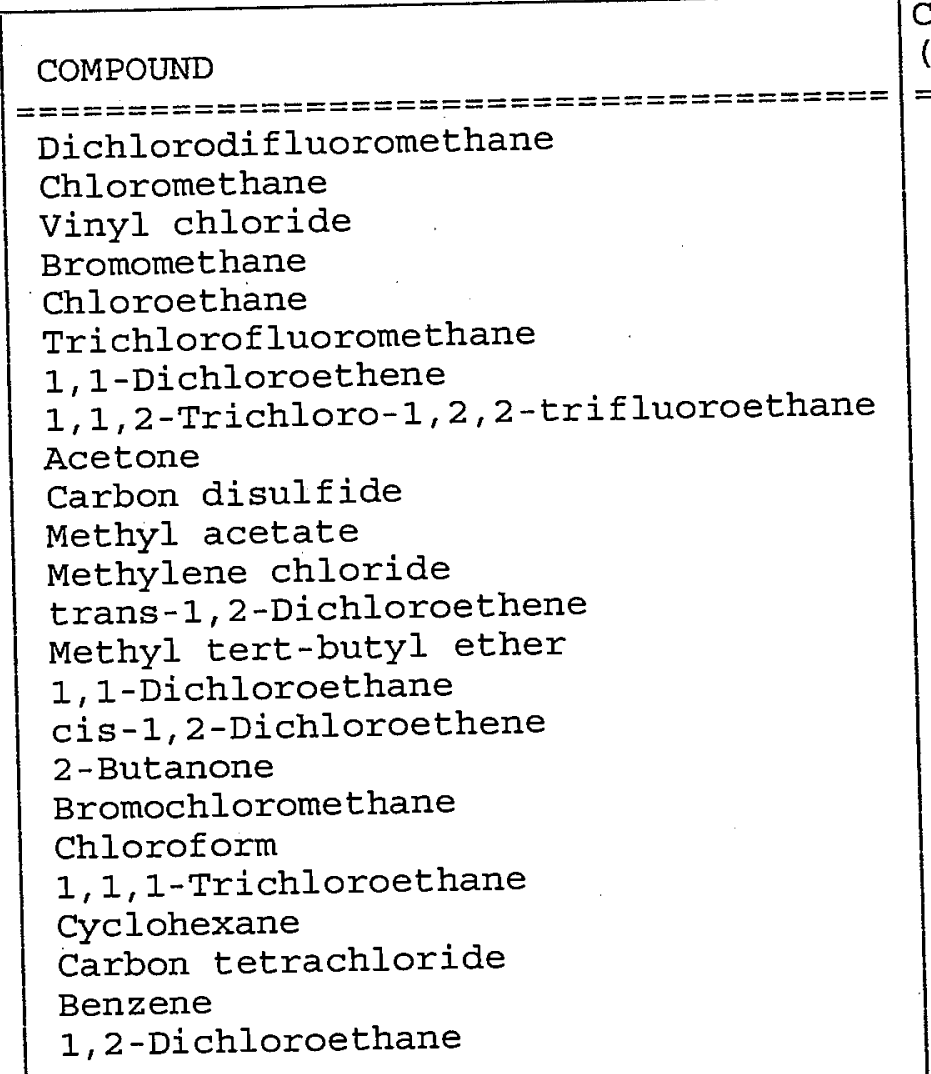 & \begin{tabular}{|cr} 
CONCENTRATION UNITS: \\
(ug/I Or ug/kg) & ug/L \\
$==================$ \\
0.50 \\
0.50 \\
0.50 \\
0.50 \\
0.50 \\
0.50 \\
0.50 \\
0.50 \\
5.0 \\
0.50 \\
0.50 \\
0.50 \\
0.50 \\
0.50 \\
0.50 \\
0.50 \\
5.0 \\
0.50 \\
0.50 \\
0.50 \\
0.50 \\
0.50 \\
0.50 \\
0.50
\end{tabular} & 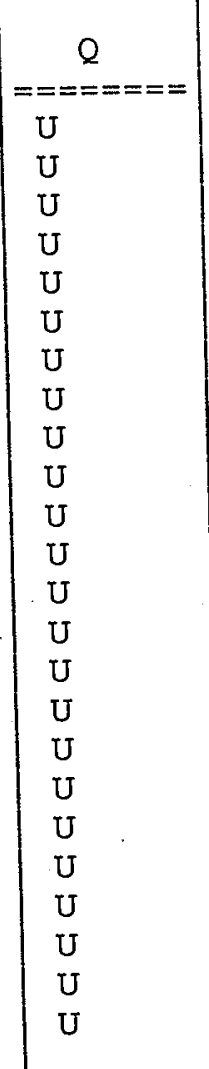 \\
\hline
\end{tabular}

Report 1,4-Dioxane for Low-Medium VOA analysis only 
Lab Name: TESTAMERICA BURLINGTON

Lab Code: STLV Case No.: BARNES

Matrix: (SOIL/SED/WATER) Water

Sample wt/vol: $25.0 \quad(\mathrm{~g} / \mathrm{mL}) \mathrm{mL}$

Level: (TRACE/LOW/MED) TRACE

$\%$ Moisture: not dec.

GC Column: DB-624

ID $: 0.53$

Soil Extract Volume:

Purge Volume: 25.0
Contract: $8 \mathrm{E}-00302$

Mod. Ref No.:

SDG NO.: 133894
Lab Sample ID: 808353

Lab File ID: 808353

Date Received: 10/01/2009

Date Analyzed: 10/06/2009

(mm) Dilution Factor: 1.0

(uL) Soil Aliquot Volume:

(uL)

(m)

\begin{tabular}{|c|c|c|c|}
\hline $\begin{array}{l}\text { CAS NO. } \\
===========\end{array}$ & COMPOUND & $\begin{array}{l}\text { CONCENTRATION UNITS: } \\
(\mathrm{ug} / \mathrm{L} \text { or } \mathrm{ug} / \mathrm{kg}) \mathrm{ug} / \mathrm{L}\end{array}$ & Q \\
\hline $\begin{aligned}==== & ====== \\
& 79-01-6\end{aligned}$ & 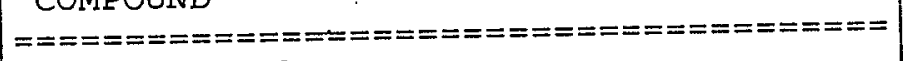 & 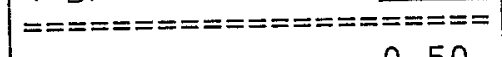 & $=======$ \\
\hline $\begin{array}{r}79-01-6 \\
108-87-2\end{array}$ & Trichloroethene & 0.50 & $\mathrm{U}$ \\
\hline $\begin{array}{r}108-87-2 \\
78-87-5\end{array}$ & Methylcyclohexane & 0.50 & U \\
\hline $\begin{array}{l}78-87-5 \\
75-27-4\end{array}$ & 1,2-Dichloropropane & 0.50 & $\begin{array}{l}\mathrm{U} \\
\mathrm{U}\end{array}$ \\
\hline $\begin{array}{r}75-27-4 \\
10061-01-5\end{array}$ & Bromodichloromethane & $\begin{array}{l}0.50 \\
0.50\end{array}$ & $\begin{array}{l}U \\
U\end{array}$ \\
\hline $\begin{array}{r}10061-01-5 \\
108-10-1\end{array}$ & cis-1,3-Dichloropropene & 5.0 & U \\
\hline $\begin{array}{l}108-10-1 \\
108-88-3\end{array}$ & $\begin{array}{l}\text { 4-Methyl-2-pentanone } \\
\text { Toluene }\end{array}$ & 0.50 & U \\
\hline $\begin{array}{r}108-88-3 \\
10061-02-6\end{array}$ & $\begin{array}{l}\text { Toluene } \\
\text { trans-1,3-Dichloropropene }\end{array}$ & 0.50 & U \\
\hline $\begin{array}{r}10061-02-6 \\
79-00-5\end{array}$ & $\begin{array}{l}\text { trans-1,3-Dichloropropene } \\
1,1,2 \text {-Trichloroethane }\end{array}$ & 0.50 & $\mathrm{U}$ \\
\hline $\begin{array}{r}79-00-5 \\
127-18-4\end{array}$ & Tetrachloroethene & 0.50 & U \\
\hline $591-78-6$ & 2 -Hexanone & 5.0 & U \\
\hline $124-48-1$ & Dibromochloromethane & 0.50 & U \\
\hline $106-93-4$ & 1,2-Dibromoethane & 0.50 & $\mathrm{U}$ \\
\hline $108-90-7$ & Chlorobenzene & 0.50 & U \\
\hline $100-41-4$ & Ethylbenzene & 0.50 & $\mathrm{U}$ \\
\hline $95-47-6$ & o-Xylene & 0.50 & U \\
\hline $179601-23-1$ & $\mathrm{~m}, \mathrm{p}$-Xylene & 0.50 & U \\
\hline $100-42-5$ & Styrene & 0.50 & $\mathrm{U}$ \\
\hline $75-25-2$ & Bromoform & 0.50 & $\mathrm{U}$ \\
\hline $98-82-8$ & Isopropylbenzene & 0.50 & U \\
\hline $79-34-5$ & $1,1,2,2$-Tetrachloroethane & 0.50 & U \\
\hline $541-73-1$ & 1,3-Dichlorobenzene & 0.50 & $\mathrm{U}$ \\
\hline $106-46-7$ & 1,4 -Dichlorobenzene & 0.50 & $\mathrm{U}$ \\
\hline $95-50-1$ & 1,2-Dichlorobenzene & 0.50 & $\mathrm{U}$ \\
\hline $96-12-8$ & 1,2-Dibromo-3-chloropropane & 0.50 & $\mathrm{U}$ \\
\hline $120-82-1$ & $1,2,4$-Trichlorobenzene & 0.50 & U \\
\hline $87-61-6$ & $1,2,3$-Trichlorobenzene & 0.50 & $U$ \\
\hline
\end{tabular}


$1 A$ - FORM I VOA-1

VOLATILE ORGANICS ANALYSIS DATA SHEET
EPA SAMPLE NO.

QCTBW2 8713
Lab Name: TESTAMERICA BURIINGTON

Lab Code: STLV Case No.: BARNES

Matrix: (SOIL/SED/WATER) water

Sample wt/vol: 25.0

(g/m工 $\mathrm{mL}$

Level: (TRACE/LOW/MED) TRACE

\% Moisture: not dec.

GC Column: DB-624

ID : 0.53

(mm)

(uL)

Contract: $8 \mathrm{E}-00302$

Mod. Ref No.:
Soil Extract Volume:

Purge Volume: 25.0
Lab Sample ID: 808354

Lab File ID: 808354

Date Received: 10/01/2009

Date Analyzed: 10/06/2009

Dilution Factor: 1.0

Soil Aliquot Volume:

(m山)

\begin{tabular}{|c|c|c|c|}
\hline $\begin{array}{r}\text { CAS NO. } \\
========= \\
75-71-8 \\
74-87-3 \\
75-01-4 \\
74-83-9 \\
75-00-3 \\
75-69-4 \\
75-35-4 \\
76-13-1 \\
67-64-1 \\
75-15-0 \\
79-20-9 \\
75-09-2 \\
156-60-5 \\
1634-04-4 \\
75-34-3 \\
156-59-2 \\
78-93-3 \\
74-97-5 \\
67-66-3 \\
71-55-6 \\
110-82-7 \\
56-23-5 \\
71-43-2 \\
107-06-2\end{array}$ & 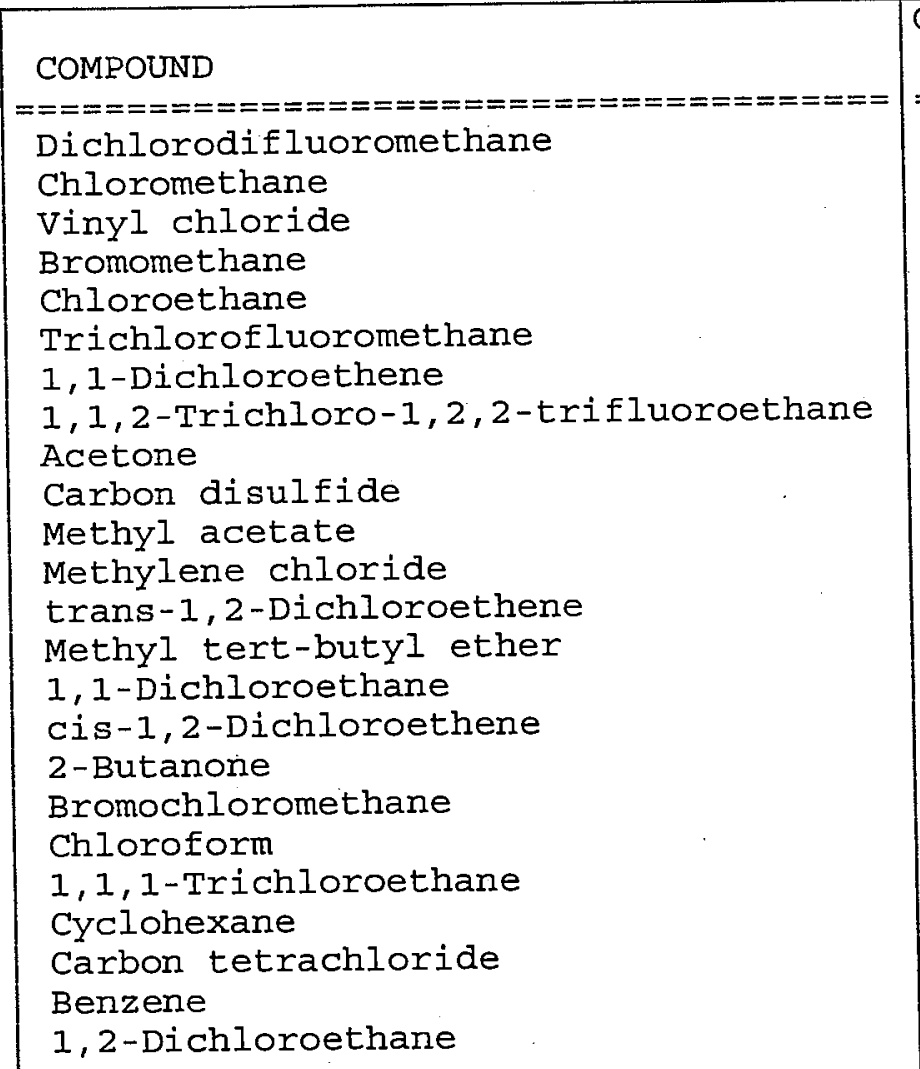 & \begin{tabular}{|cr} 
CONCENTRATION UNITS: \\
(ug/L or ug/kg) & ug $/ \mathrm{L}$ \\
$=============$ \\
0.50 \\
0.50 \\
0.50 \\
0.50 \\
0.50 \\
0.50 \\
0.50 \\
0.50 \\
1.8 \\
0.50 \\
0.50 \\
0.50 \\
0.50 \\
0.50 \\
0.50 \\
0.50 \\
5.0 \\
0.50 \\
0.50 \\
0.50 \\
0.50 \\
0.50 \\
0.50 \\
0.50
\end{tabular} & $\begin{array}{l}====== \\
U \\
U \\
U \\
U \\
U \\
U \\
U \\
U \\
J \\
U \\
U \\
U \\
U \\
U \\
U \\
U \\
U \\
U \\
U \\
U \\
U \\
U \\
U \\
U\end{array}$ \\
\hline
\end{tabular}

Report 1,4-Dioxane for Low-Medium VOA analysis only 
Lab Name: TESTAMERICA BURLINGTON

Lab Code: STLV Case No.: BARNES

Matrix: (SOIL/SED/WATER) Water

Sample wt/vol: 25.0

$(g / m L) \quad m L$

Level: (TRACE/LOW/MED) TRACE

\% Moisture: not dec.

GC Column: DB-624

Soil Extract Volume:

ID $: 0.53 \quad(\mathrm{~mm})$

(uL)

(m山)

Purge Volume: 25.0
Contract: $8 \mathrm{E}-00302$

Mod. Ref No.:

Lab Sample ID: 808354

Lab File ID: 808354

Date Received: 10/01/2009

Date Analyzed: 10/06/2009

Dilution Factor: 1.0

Soil Aliquot Volume:

(UL)

\begin{tabular}{|c|c|c|c|}
\hline CAS NO. & COMPOUND & $\begin{array}{l}\text { CONCENTRATION UNITS: } \\
(\mathrm{ug} / \mathrm{L} \text { or } \mathrm{ug} / \mathrm{kg}) \mathrm{ug} / \mathrm{L}\end{array}$ & Q \\
\hline$==========$ & 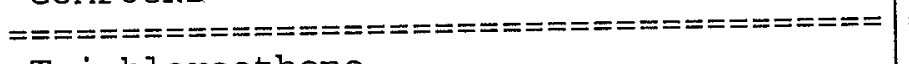 & 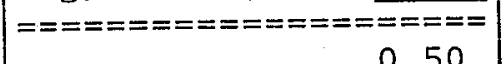 & $========$ \\
\hline $79-01-6$ & Trichloroethene & 0.50 & $\mathrm{U}$ \\
\hline $108-87-2$ & Methylcyclohexane & 0.50 & $\mathrm{U}$ \\
\hline $78-87-5$ & 1,2-Dichloropropane & 0.50 & $\mathrm{U}$ \\
\hline $75-27-4$ & Bromodichloromethane & 0.50 & $\mathrm{U}$ \\
\hline $10061-01-5$ & cis-1,3-Dichloropropene & 0.50 & $\mathrm{U}$ \\
\hline $108-10-1$ & 4-Methyl-2-pentanone & 5.0 & $\mathrm{U}$ \\
\hline $108-88-3$ & Toluene & 0.31 & $\mathrm{~J}$ \\
\hline $10061-02-6$ & trans-1,3-Dichloropropene & 0.50 & $\mathrm{U}$ \\
\hline $79-00-5$ & $1,1,2$-Trichloroethane & 0.50 & $\mathrm{U}$ \\
\hline $127-18-4$ & Tetrachloroethene & 0.50 & $\mathrm{U}$ \\
\hline $591-78-6$ & 2-Hexanone & 5.0 & U \\
\hline $124-48-1$ & Dibromochloromethane & 0.50 & $\mathrm{U}$ \\
\hline $106-93-4$ & 1,2-Dibromoethane & 0.50 & $\mathrm{U}$ \\
\hline $108-90-7$ & Chlorobenzene & 0.50 & $\mathrm{U}$ \\
\hline $100-41-4$ & Ethylbenzene & 0.50 & $\mathrm{U}$ \\
\hline $95-47-6$ & o-Xylene & 0.50 & $\mathrm{U}$ \\
\hline $179601-23-1$ & $\mathrm{~m}, \mathrm{p}$-Xylene & 0.20 & $\mathrm{~J}$ \\
\hline $100-42-5$ & Styrene & 0.50 & U \\
\hline $75-25-2$ & Bromoform & 0.50 & $\mathrm{U}$ \\
\hline $98-82-8$ & Isopropylbenzene & 0.50 & $\mathrm{U}$ \\
\hline $79-34-5$ & $1,1,2,2$-Tetrachloroethane & 0.50 & $\mathrm{U}$ \\
\hline $541-73-1$ & 1,3 -Dichlorobenzene & 0.50 & $\mathrm{U}$ \\
\hline $106-46-7$ & 1,4 -Dichlorobenzene & 0.50 & $\mathrm{U}$ \\
\hline $95-50-1$ & 1,2 -Dichlorobenzene & 0.50 & U \\
\hline $96-12-8$ & 1,2-Dibromo-3-chloropropane & 0.50 & $\mathrm{U}$ \\
\hline $120-82-1$ & $1,2,4$-Trichlorobenzene & 0.50 & $\mathrm{U}$ \\
\hline $87-61-6$ & 1,2,3-Trichlorobenzene & 0.50 & $\mathrm{U}$ \\
\hline
\end{tabular}


$1 A$ - FORM I VOA-1

VOLATILE ORGANICS ANALYSIS DATA SHEET
EPA SAMPLE NO.

VHBLKOI
Lab Name: TESTAMERICA BURLINGTON

Lab Code: STLV Case No.: BARNES

Matrix: (SOIL/SED/WATER) Water

Sample wt/vol: $25.0 \quad(\mathrm{~g} / \mathrm{mL}) \mathrm{mL}$

Level: (TRACE/LOW/MED) TRACE

\% Moisture: not dec.

GC Column: DB-624

Soil Extract Volume:

ID : $0.53 \quad(\mathrm{~mm})$

(UI)

Contract: 8E-00302

Mod. Ref No.:

SDG NO.: 133894

Lab Sample ID: 808355

Lab File ID: 808355

Date Received:

Date Analyzed: 10/06/2009

Dilution Factor: 1.0

Soil Aliquot Volume:

Purge Volume: 25.0

(uI)

(mL)

\begin{tabular}{|c|c|c|c|}
\hline $\begin{array}{l}\text { CAS NO. } \\
========== \\
75-71-8 \\
74-87-3 \\
75-01-4 \\
74-83-9 \\
75-00-3 \\
75-69-4 \\
75-35-4 \\
76-13-1 \\
67-64-1 \\
75-15-0 \\
79-20-9 \\
75-09-2 \\
156-60-5 \\
1634-04-4 \\
75-34-3 \\
156-59-2 \\
78-93-3 \\
74-97-5 \\
67-66-3 \\
71-55-6 \\
110-82-7 \\
56-23-5 \\
71-43-2 \\
107-06-2\end{array}$ & $\begin{array}{l}\text { Compound } \\
============================ \\
\text { Dichlorodifluoromethane } \\
\text { Chloromethane } \\
\text { Vinyl chloride } \\
\text { Bromomethane } \\
\text { Chloroethane } \\
\text { Trichlorofluoromethane } \\
1,1-D i c h l o r o e t h e n e \\
1,1,2-\text { Trichloro-1, } 2,2-\text { trifluoroethane } \\
\text { Acetone } \\
\text { Carbon disulfide } \\
\text { Methyl acetate } \\
\text { Methylene chloride } \\
\text { trans-1,2-Dichloroethene } \\
\text { Methyl tert-butyl ether } \\
1,1-D i c h l o r o e t h a n e \\
\text { cis-1,2-Dichloroethene } \\
2-\text { Butanone } \\
\text { Bromochloromethane } \\
\text { Chloroform } \\
1,1,1-\text { Trichloroethane } \\
\text { Cyclohexane } \\
\text { Carbon tetrachloride } \\
\text { Benzene } \\
1,2-D i c h l o r o e t h a n e\end{array}$ & \begin{tabular}{|cr} 
CONCENTRATION UNITS : \\
(ug/L or ug/kg) & ug $/ \mathrm{L}$ \\
$================$ \\
0.50 \\
0.50 \\
0.50 \\
0.50 \\
0.50 \\
0.50 \\
0.50 \\
0.50 \\
5.0 \\
0.50 \\
0.50 \\
0.50 \\
0.50 \\
0.50 \\
0.50 \\
0.50 \\
5.0 \\
0.50 \\
0.50 \\
0.50 \\
0.50 \\
0.50 \\
0.50 \\
0.50
\end{tabular} & $\begin{array}{l}====== \\
\mathrm{U} \\
\mathrm{U} \\
\mathrm{U} \\
\mathrm{U} \\
\mathrm{U} \\
\mathrm{U} \\
\mathrm{U} \\
\mathrm{U} \\
\mathrm{U} \\
\mathrm{U} \\
\mathrm{U} \\
\mathrm{U} \\
\mathrm{U} \\
\mathrm{U} \\
\mathrm{U} \\
\mathrm{U} \\
\mathrm{U} \\
\mathrm{U} \\
\mathrm{U} \\
\mathrm{U} \\
\mathrm{U} \\
\mathrm{U} \\
\mathrm{U} \\
\mathrm{U}\end{array}$ \\
\hline
\end{tabular}

Report 1,4-Dioxane for Low-Medium VOA analysis only 
Lab Name: TESTAMERICA BURLINGTON

Lab Code: STLV Case No.: BARNES

Matrix: (SOIL/SED/WATER) Water

Sample $w t / v o l: 25.0$

$(\mathrm{g} / \mathrm{mL}) \mathrm{mL}$

\section{Level: (TRACE/LOW/MED) TRACE}

$\%$ Moisture: not dec.

GC Column: DB-624

Soil Extract Volume:

ID: $0.53 \quad(\mathrm{~mm})$

(uL)

Contract: $8 \mathrm{E}-00302$

Mod. Ref No.:

Lab Sample ID: 808355

Lab File ID: 808355

Date Received:

Dilution Factor: 1.0

Soil Aliquot Volume:
SDG NO.: 133894

Purge Volume: 25.0

Date Analyzed: 10/06/2009

(uL)

$(\mathrm{mL})$

\begin{tabular}{|c|c|c|c|}
\hline $\begin{array}{r}\text { CAS NO. } \\
========== \\
79-01-6 \\
108-87-2 \\
78-87-5 \\
75-27-4 \\
10061-01-5 \\
108-10-1 \\
108-88-3 \\
10061-02-6 \\
79-00-5 \\
127-18-4 \\
591-78-6 \\
124-48-1 \\
106-93-4 \\
108-90-7 \\
100-41-4 \\
95-47-6 \\
179601-23-1 \\
100-42-5 \\
75-25-2 \\
98-82-8 \\
79-34-5 \\
541-73-1 \\
106-46-7 \\
95-50-1 \\
96-12-8 \\
120-82-1 \\
87-61-6\end{array}$ & 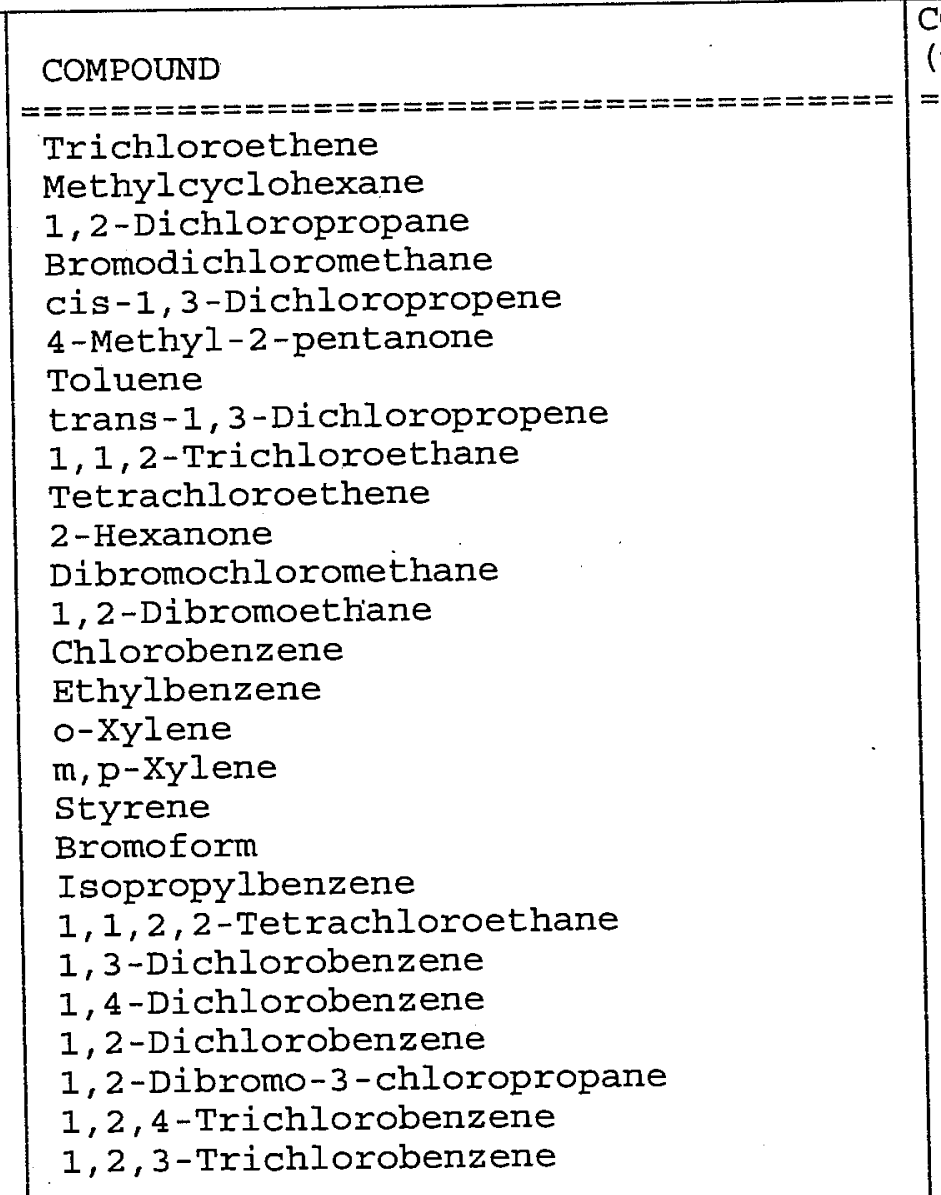 & 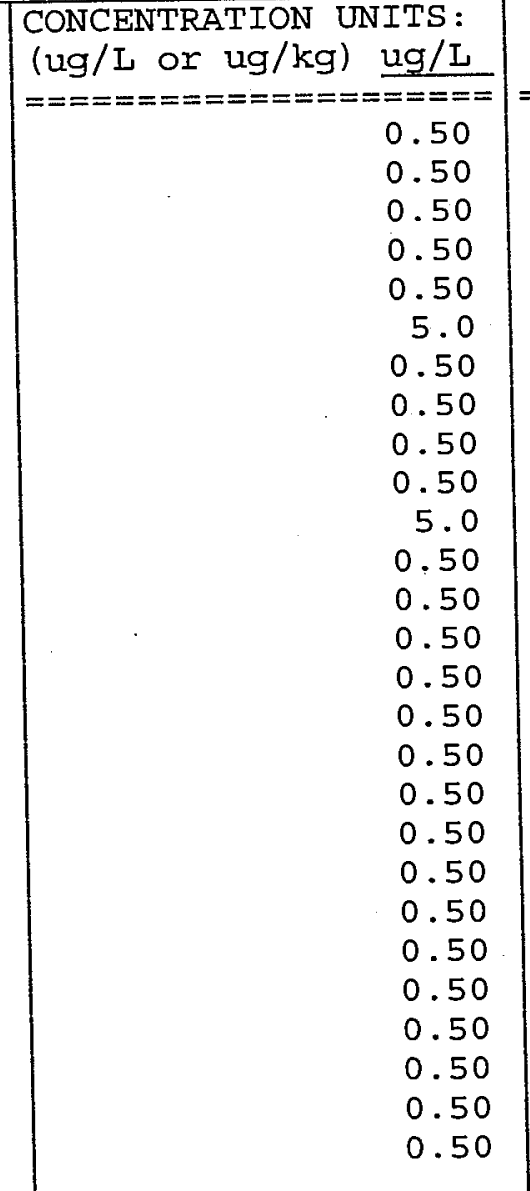 & $\begin{array}{l}======= \\
U \\
U \\
U \\
U \\
U \\
U \\
U \\
U \\
U \\
U \\
U \\
U \\
U \\
U \\
U \\
U \\
U \\
U \\
U \\
U \\
U \\
U \\
U \\
U \\
U \\
U \\
U\end{array}$ \\
\hline
\end{tabular}




\section{Appendix E:}

Trend Analysis of Carbon Tetrachloride

Concentration Data for Monitored Wells 


\section{Contents}

E.1 Background and Investigation Approach ………….................................................. E-5

E.2 Results of the Trend Analyses ......................................................................... E-6

E.2.1 Individual Review of Wells Completed in the Deep Aquifer Zone............... E-7

E.2.1.1 Well MW16S ........................................................................... E-7

E.2.1.2 Wells MW6S/D .................................................................. E- E

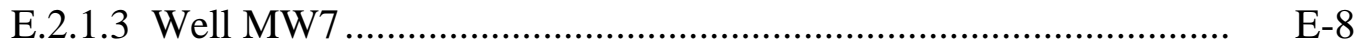

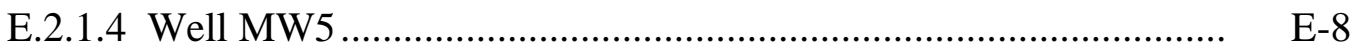

E.2.1.5 Well MW15S ................................................................ E- E-9

E.2.1.6 Oentrich Private Well .................................................................. E-9

E.2.1.7 Well MW10D .................................................................. E-10

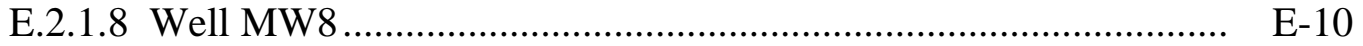

E.2.1.9 Well MW4D ............................................................... E-10

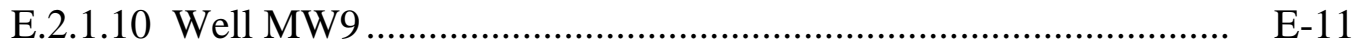

E.2.1.11 Well MW12D ................................................................. E-

E.2.1.12 Well MW11D ................................................................ E-12

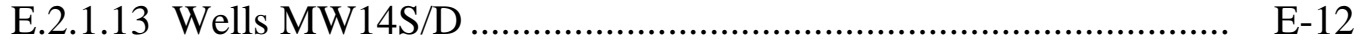

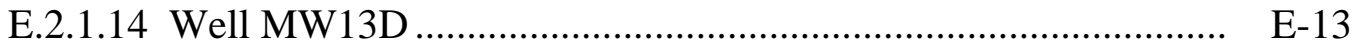

E.2.1.15 Well MW1D ........................................................................... E-13

E.2.2 Individual Review of Wells Completed in the Intermediate Aquifer

Zone

E-14

E.2.2.1 Well MW10S ............................................................... E-14

E.2.2.2 Well MW12M ................................................................... E-15

E.2.2.3 Well MW11M ................................................................ E-

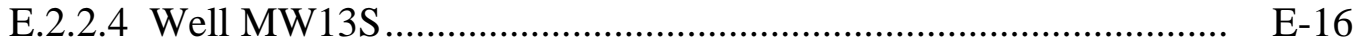

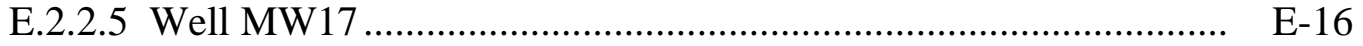

E.2.3 Individual Review of the Public Supply Wells............................................. E-17

E.2.3.1 Well PWS2 …………………............................................. E-17

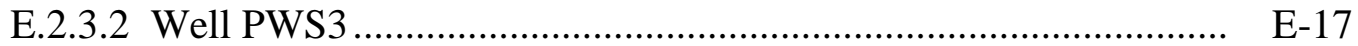

E.2.4 Spatial Distribution of Possible Concentration Trends for the Deep and Intermediate Aquifer Zones ...................................................................... E-18

E.2.4.1 Trends for the Intermediate Aquifer Zone..................................... E-18

E.2.4.2 Trends for the Deep Aquifer Zone ……………………………. $\quad$ E-19

E.3 Summary and Recommendations ……………............................................... E-21

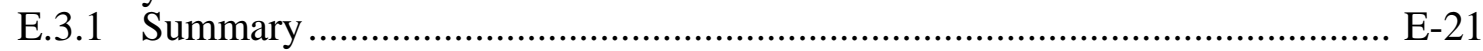

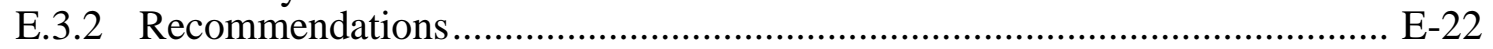

\section{Table}

E.1 Monitoring wells proposed for annual monitoring at Barnes, with carbon tetrachloride concentration trends. 


\section{Figures}

E.1 Plot of concentration versus time for deep-zone well MW16S

E.2 Plot of concentration versus time for deep-zone well MW6S

E-25

E.3 Plot of concentration versus time for deep-zone well MW6D

E-26

E.4 Plot of concentration versus time for deep-zone well MW7

E.5 Plot of concentration versus time for deep-zone well MW5

E.6 Plot of concentration versus time for deep-zone well MW15S

E.7 Plot of concentration versus time for the Oentrich private well

E.8 Plot of concentration versus time for deep-zone well MW10D

E.9 Plot of concentration versus time for deep-zone well MW8

E.10 Plot of concentration versus time for deep-zone well MW4D

E.11 Plot of concentration versus time for deep-zone well MW9

E.12 Plot of concentration versus time for deep-zone well MW12D

E.13 Plot of concentration versus time for deep-zone well MW11D E-36

E.14 Plot of concentration versus time for deep-zone well MW14S

E.15 Plot of concentration versus time for deep-zone well MW14D

E.16 Plot of concentration versus time for deep-zone well MW13D

E.17 Plot of concentration versus time for deep-zone well MW1D E-40

E.18 Plot of concentration versus time for intermediate-zone well MW10S ........................ E-41

E.19 Plot of concentration versus time for intermediate-zone well MW12M E-42 
E.20 Plot of concentration versus time for intermediate-zone well MW11M .................... E-43

E.21 Plot of concentration versus time for intermediate-zone well MW13S..................... E-44

E.22 Plot of concentration versus time for intermediate-zone well MW17 ....................... E-45

E.23 Plot of concentration versus time for well PWS2 .................................................. E-46

E.24 Plot of concentration versus time for well PWS3 ................................................ E-47

E.25 Distribution of apparent carbon tetrachloride trends in the intermediate aquifer zone E-48

E.26 Distribution of apparent carbon tetrachloride trends in the deep aquifer zone............ E-49 


\section{Appendix E:}

\section{Trend Analysis of Carbon Tetrachloride Concentration Data for Monitored Wells}

\section{E.1 Background and Investigation Approach}

At the request of the KDHE, the monitoring data for Barnes were examined for possible temporal or spatial trends in the levels of carbon tetrachloride within the groundwater plume. The primary technical objective of this trend analysis was to evaluate whether the present monitoring results might assist in anticipating potential future changes in the contaminant distribution at this site and hence the risks that might be posed to public water supply wells PWS2 and PWS3. This analysis considered each of the regularly sampled groundwater monitoring points, including KDHE monitoring wells MW1D-MW4D; CCC/USDA monitoring wells MW5, MW6S/D, MW7-MW9, MW10S/D, MW11S/M/D, MW12S/M/D, MW13S/D, MW14S/D, MW15S/D, MW16S/D, MW17; the Oentrich private well; and public supply wells PWS2 and PWS3. The contaminant levels identified in each well were plotted, where appropriate (see below), as concentration-versus-time graphs.

Review of the complete analytical data set for all sampling events from July 2006 to September-October 2009 (Table 4.3) indicates that no carbon tetrachloride has been identified to date in deep-zone wells MW2D, MW3D, and MW16D or in shallow-zone well MW11S. Carbon tetrachloride was detected only once (in November 2007), at a concentration of $0.2 \mu \mathrm{g} / \mathrm{L}$, in deep-zone well MW15D. No groundwater has been recovered for analysis from shallow-zone well MW1S, because this well has remained consistently dry. Shallow-zone well MW12S has also remained dry, except in June 2009; at that time, no carbon tetrachloride was detected in a groundwater sample obtained from well MW12S. For these reasons, concentration-versus-time graphs were not prepared for these wells.

The concentration-versus-time diagrams prepared for monitoring wells, the Oentrich private well, and the public water supply wells are in Figures E.1-E.24. For each well, concentration values reported as falling below the analytical method quantification limit $(1.0 \mu \mathrm{g} / \mathrm{L})$ but above the instrumental detection limit $(0.1 \mu \mathrm{g} / \mathrm{L})$ are plotted as the estimated values marked in Table 4.3 by the qualifier "J." For graphing purposes, analysis results reported as "not detected" (ND) are plotted as the instrumental detection limit $(0.1 \mu \mathrm{g} / \mathrm{L})$. 
As shown in Table 4.3, groundwater sampling for VOCs analyses has been conducted periodically in some or all of the identified monitoring, private, and public water supply wells since July 2006. Prior to March 2008, a conventional three-well-volume purging method was used for sample collection. Beginning with the March 2008 monitoring event, all groundwater samples from monitoring wells have been collected by using a low-flow method of purging and sampling. The results obtained by each of these methods are distinguished in Figures E.1-E.6 and E.8-E.22. Sampling of the Oentrich private well (Figure E.7) and public wells PWS2 and PWS3 (Figures E.23 andE.24, respectively) has been performed throughout the groundwater monitoring program by using the existing pump in each well to purge for a specified period.

The analytical data in Table 4.3 represent a maximum observation period of approximately 38 months. With the approval of the KDHE, eight groundwater sampling events were conducted at most of the monitoring points during this time. One or more additional sampling events were performed at selected wells (MW1D-MW4D, Oentrich, PWS2, PWS3) to meet specific program needs.

To assist in the evaluation of the monitoring results, linear regression was used to estimate possible concentration trends (where appropriate) for selected wells based on a leastsquares fit to the concentration-versus-time values. For each regression, a value $\left(R^{2}\right)$ reflecting the statistical goodness of fit of the measured concentration values to the calculated trend line is shown. Values of $R^{2}$ range from 0 to 1 . Higher $R^{2}$ values indicate a relatively greater degree of correlation between the values of concentration and time. It must be recognized, however, that the duration of the monitoring effort at Barnes to date has been relatively brief in comparison to the potential period during which the migration of carbon tetrachloride in groundwater (associated with the former CCC/USDA facility) might have been occurring at this site. Definitive recognition of potentially significant concentration trends within the plume on the basis of the current, relatively limited (both in time and in the number of individual measurements) data sets is therefore problematic. In light of these factors, the observations presented in the following sections are largely empirical and are subject to further interpretation as additional monitoring data are accumulated over time.

\section{E.2 Results of the Trend Analyses}

The concentration-versus-time graphs for wells in which carbon tetrachloride has been identified, at least once, at a concentration above the instrumental detection limit $(0.1 \mu \mathrm{g} / \mathrm{L})$ are 
discussed individually below. For convenience, the results for wells in the deep aquifer zone are presented first, followed by results for wells in the intermediate zone. For each aquifer interval, the wells are presented in approximate areal progression from east to west across the Barnes site, and hence in the apparent direction of potential contaminant migration (when the public water supply wells are pumping) from the former CCC/USDA facility toward wells PWS2 and PWS3 (Figures 4.1b). Summary observations regarding the potential evolution of the carbon tetrachloride distribution in groundwater at Barnes are then provided.

\section{E.2.1 Individual Review of Wells Completed in the Deep Aquifer Zone}

\section{E.2.1.1 Well MW16S}

Well MW16S lies northeast of the former CCC/USDA facility, in the apparent downgradient direction of groundwater flow across the site under ambient, non-pumping conditions. Well MW16S is completed with a 10-ft screen. The concentration-versus-time graph for this well is in Figure E.1.

No carbon tetrachloride was detected in this well during the April and November 2007 sampling events conducted with the three-well-volume purge method. Carbon tetrachloride was initially detected in this well, at $0.4 \mu \mathrm{g} / \mathrm{L}$, during the first sampling event performed with the low-flow method (March 2008). Since that event, the identified concentrations at MW16S have increased fairly steadily, but they have remained well below the KDHE RBSL value of 5.0 $\mu \mathrm{g} / \mathrm{L}$ throughout the period of record, reaching a maximum of $1.7 \mu \mathrm{g} / \mathrm{L}$ in the September-October 2009 sampling event.

\section{E.2.1.2 Wells MW6S/D}

Wells MW6S and MW6D lie east-southeast of the former CCC/USDA facility, at a location that is generally downgradient from the former facility under non-pumping conditions. Both wells are completed in the deep aquifer zone, with 10-ft screens. The observed carbon tetrachloride concentrations in these wells have remained well below the KDHE RBSL value of $5.0 \mu \mathrm{g} / \mathrm{L}$ throughout the period of record (Figures E.2 and E.3). 
Carbon tetrachloride was identified in well MW6S at concentrations of $0.3-0.4 \mu \mathrm{g} / \mathrm{L}$ in the April and November 2007 sampling events conducted with the three-well-volume purge method. No subsequent detections by the low-flow sampling method have occurred to date, however, at this well.

Carbon tetrachloride was not detected at MW6D during the initial (April 2007; threewell-volume purge ) sampling event, but the contaminant has been detected in all subsequent events at values that have slowly but steadily increased to a maximum of $1.5 \mu \mathrm{g} / \mathrm{L}$ in June and September-October 2009.

\section{E.2.1.3 Well MW7}

Well MW7 is located just outside the southeast boundary of the former CCC/USDA facility, and hence it lies approximately downgradient of the former facility under ambient groundwater flow conditions. Well MW7 has a 10-ft screen. The concentration-versus-time graph for this well is in Figure E.4.

Carbon tetrachloride has been detected in each monitoring event since sampling began at this well in April 2007, at levels below the KDHE RBSL value of $5.0 \mu \mathrm{g} / \mathrm{L}$. The results obtained by using the three-well-volume purge and low-flow sampling methods are comparable and have shown relatively little variation, ranging from $1.0 \mu \mathrm{g} / \mathrm{L}$ to $2.8 \mu \mathrm{g} / \mathrm{L}$. Figure E.4 indicates that the concentrations at this well have decreased slightly since reaching an apparent maximum in March 2008 (the first event conducted with the low-flow sampling method).

\section{E.2.1.4 Well MW5}

Well MW5 lies just outside the northeastern limit of the former CCC/USDA facility and is downgradient of the former facility under ambient groundwater flow conditions. Well MW5 has a 10-ft screen. The concentration-versus-time graph for this well is in Figure E.5.

Carbon tetrachloride concentrations of $<1 \mu \mathrm{g} / \mathrm{L}$ were consistently observed at this well during the sampling events (both three-well-volume purge and low-flow) conducted from April 2007 until July 2008. Since the July 2008 event, the identified concentrations at this well have increased fairly steadily. The observed concentration at MW5 exceeded the KDHE RBSL level 
for the first time during the most recent sampling event, in September-October 2009, reaching a maximum of $7.2 \mu \mathrm{g} / \mathrm{L}$.

\section{E.2.1.5 Well MW15S}

Well MW15S (and also MW15D) is located north of the former CCC/USDA facility, at a position that is generally cross-gradient to the interpreted patterns of groundwater flow, both under ambient conditions and during pumping of the public water supply wells. Well MW15S is completed with a 10-ft screen. The concentration-versus-time graph for this well is in Figure E.6.

With one exception (below), the identified concentrations of carbon tetrachloride in this well have remained below the KDHE RBSL value of $5.0 \mu \mathrm{g} / \mathrm{L}$ throughout the period of record.

Carbon tetrachloride has been detected in the groundwater at well MW15S during each sampling event. The contaminant levels observed have generally been fairly consistent, ranging from $1.5 \mu \mathrm{g} / \mathrm{L}$ to $3.2 \mu \mathrm{g} / \mathrm{L}$, but they appear to show a pattern of slow increase. During the November 2007 sampling event (the last event performed with the three-well-volume purge method) a carbon tetrachloride concentration of $8.7 \mu \mathrm{g} / \mathrm{L}$ was identified in this well; this contaminant level was not confirmed by any subsequent or previous sampling and therefore appears potentially anomalous.

\section{E.2.1.6 Oentrich Private Well}

The Oentrich well lies south of the former CCC/USDA facility, at a position that is generally cross-gradient to the interpreted patterns of groundwater flow, both under ambient conditions and during pumping of the public water supply wells. The specific interval screened in the Oentrich well is unknown. The concentration-versus-time graph for this well is in Figure E.7.

Carbon tetrachloride has been detected in this well during each sampling event, at levels ranging from $0.3 \mu \mathrm{g} / \mathrm{L}$ to $1.6 \mu \mathrm{g} / \mathrm{L}$. Figure E.7 suggests a possible trend of very slowly increasing concentrations in the Oentrich well; however, the values in this well have remained well below the KDHE RBSL value of $5.0 \mu \mathrm{g} / \mathrm{L}$ throughout the period of record. 


\section{E.2.1.7 Well MW10D}

Well MW10D is located in the east central portion of the former CCC/USDA grain storage facility. Well MW10D has a 10-ft screen. The concentration-versus-time graph for this well is in Figure E.8.

Figure E.8 indicates that the carbon tetrachloride concentrations at this well have been relatively consistent since November 2007, ranging from $3.9 \mu \mathrm{g} / \mathrm{L}$ to $6.2 \mu \mathrm{g} / \mathrm{L}$. A weakly defined pattern of concentration decrease is suggested for this period. The somewhat lower concentration $(2.4 \mu \mathrm{g} / \mathrm{L})$ observed during the initial April 2007 (three-well-volume purge) sampling of this well was not reproduced in any subsequent sampling event. The observed concentrations at MW10D have been slightly below, approximately equal to, or slightly above the KDHE RBSL value of $5.0 \mu \mathrm{g} / \mathrm{L}$ since the November 2007 sampling event.

\section{E.2.1.8 Well MW8}

Well MW8 is located just inside the south central boundary of the former CCC/USDA facility; the well is completed with a 10-ft screen. The concentration-versus-time graph for well MW8 is in Figure E.9.

The identified carbon tetrachloride levels at MW8 have been greater than the KDHE RBSL value of $5.0 \mu \mathrm{g} / \mathrm{L}$ throughout the monitoring program, ranging from $14 \mu \mathrm{g} / \mathrm{L}$ to $29 \mu \mathrm{g} / \mathrm{L}$. These consistently represent the highest concentrations identified to date in groundwater samples from the deep aquifer zone. Figure E.9 indicates that the carbon tetrachloride concentrations at MW8 have increased relatively consistently throughout the period of record.

\section{E.2.1.9 Well MW4D}

Well MW4D is located in the west central portion of the former CCC/USDA facility. This well was installed by the KDHE with a $20-\mathrm{ft}$ screen. The concentration-versus-time graph for well MW4D is in Figure E.10.

Figure E.10 shows that the carbon tetrachloride concentrations identified in this well during the sampling events conducted with the three-well-volume purge method (in July 2006, 
April 2007, and November 2007) were consistently below the KDHE RBSL value of $5.0 \mu \mathrm{g} / \mathrm{L}$ (ranging from $1.7 \mu \mathrm{g} / \mathrm{L}$ to $3.5 \mu \mathrm{g} / \mathrm{L}$ ), with no apparent pattern of increase or decrease. In contrast, the concentration results obtained by using the low-flow sampling method (since March 2008) appear more erratic but are consistently higher than the KDHE RBSL value, reaching a maximum of $18 \mu \mathrm{g} / \mathrm{L}$ for the March 2008 sampling event. The low-flow data empirically suggest a possible, very poorly defined pattern of decreasing concentrations since March 2008. The cause of the observed variations in concentration cannot be determined from the present data; however, the noted presence of a 20 -ft screen suggests that the use of the low-flow sampling technique in this well might result in a greater sensitivity to possible heterogeneity in the concentration distribution at this location.

\section{E.2.1.10 Well MW9}

Well MW9 is located just inside the northwestern border of the former CCC/USDA facility and is constructed with a 10-ft screen. The concentration-versus-time graph for well MW9 is in Figure E.11.

The carbon tetrachloride concentrations identified at well MW9 have varied somewhat erratically throughout the period of record (ranging from $1.0 \mu \mathrm{g} / \mathrm{L}$ to $4.6 \mu \mathrm{g} / \mathrm{L}$ ) but have remained (with one exception) below the KDHE RBSL of $5.0 \mu \mathrm{g} / \mathrm{L}$. The linear regression line depicted in Figure E.11 suggests a poorly defined trend of increasing concentrations at this location; however, the slope of the line is strongly influenced by the relatively high $(4.6 \mu \mathrm{g} / \mathrm{L})$ concentration identified for the most recent (September-October 2009) sampling event. Figure E.11 illustrates that little clear pattern of concentration increase or decrease is apparent from the sampling events conducted from April 2007 until June 2009.

Despite the variability noted above, the analytical result for the groundwater sample collected in November 2007 (7.7 $\mu \mathrm{g} / \mathrm{L}$; collected by the three-well-volume purge method) appears potentially anomalous in the context of the analyses that both preceded and followed this sampling event. 


\section{E.2.1.11 Well MW12D}

Well MW12D is located north-northwest of the former CCC/USDA facility and directly east of public supply wells PWS2 and PWS3. Well MW12D appears to lie near the northern margin of the interpreted groundwater and contaminant migration fairway in the deep aquifer zone that develops toward the public water supply wells when these wells are actively pumping. Well MW12D is constructed with a $10-\mathrm{ft}$ screen. The concentration-versus-time graph for this well is in Figure E.12.

The carbon tetrachloride concentrations identified at well MW12D have remained consistently below the KDHE RBSL during the period of record, ranging from $<0.1 \mu \mathrm{g} / \mathrm{L}$ (ND) to $1.6 \mu \mathrm{g} / \mathrm{L}$. No pattern of increasing or decreasing concentrations is apparent at this well.

\section{E.2.1.12 Well MW11D}

Well MW11D is located west-northwest of the former CCC/USDA facility and eastsoutheast of wells PWS2 and PWS3. Well MW11D appears to lie near the southern margin of the interpreted groundwater and contaminant migration path that develops toward the public water supply wells when these wells are actively pumping. Well MW11D has a 10-ft screen. The concentration-versus-time graph for this well is in Figure E.13.

The carbon tetrachloride levels detected at MW11D are very similar to those observed at nearby well MW12D (Section E.2.1.11). The concentrations at MW11D have remained well below the KDHE RBSL of $5.0 \mu \mathrm{g} / \mathrm{L}$ during the period of record. The measured levels at this well have ranged from $<0.1 \mu \mathrm{g} / \mathrm{L}$ (ND) to $1.1 \mu \mathrm{g} / \mathrm{L}$, with no discernable increasing or decreasing trend.

\section{E.2.1.13 Wells MW14S/D}

Wells MW14S and MW14D are located north-northwest of the former CCC/USDA facility and east-northeast of wells PWS2 and PWS3. The MW14 wells appear to lie generally upgradient of wells PWS2 and PWS3 under the transient groundwater flow conditions that develop when these wells are actively pumping. Both MW14S and MW14D are constructed with 
10-ft screens. The concentration-versus-time graphs for wells MW14S and MW14D are in Figures E.14 and E.15, respectively.

Figure E.14 indicates that contaminant concentrations of approximately $1 \mu \mathrm{g} / \mathrm{L}$ were determined for well MW14S during the March and November 2007 (three-well-volume purge) sampling events. The results of all subsequent analyses conducted with the low-flow technique range from $3.7 \mu \mathrm{g} / \mathrm{L}$ to $5.6 \mu \mathrm{g} / \mathrm{L}$. The latter values have varied over time, from just below to just above the KDHE RBSL value of $5.0 \mu \mathrm{g} / \mathrm{L}$, showing no clear pattern of increase or decrease.

Carbon tetrachloride concentrations ranging from $<0.1 \mu \mathrm{g} / \mathrm{L}$ (ND) to $1.2 \mu \mathrm{g} / \mathrm{L}$ have been identified at well MW14D (Figure E.15). A very slight decreasing trend is suggested for these results; however, the slope of the calculated regression line is strongly influenced by the (highest) concentration detected in April 2007; little or no clear pattern of increase or decrease is observed in the measured values from November 2007 to September-October 2009.

\section{E.2.1.14 Well MW13D}

Well MW13D lies west-northwest of the former CCC/USDA facility and is approximately $400 \mathrm{ft}$ due east of wells PWS2 and PWS3, along the apparent migration pathway toward these wells that develops in the deep aquifer zone when they are actively pumping. Well MW13D has a 10-ft screen. The concentration-versus-time graph for this well is in Figure E.16.

With one possible exception, the carbon tetrachloride concentrations identified at well MW13D have ranged from just below to slightly above the KDHE RBSL of $5.0 \mu \mathrm{g} / \mathrm{L}$. Figure E.16 depicts a relatively well defined pattern of increasing contaminant levels at this location during the period of record, reaching a maximum concentration of $7.2 \mu \mathrm{g} / \mathrm{L}$ during the September-October 2009 sampling event.

A single higher concentration value $(11 \mu \mathrm{g} / \mathrm{L})$ was determined for this well during the March 2008 sampling event (the first use of the low-flow method). This value does not appear consistent, however, with the apparent trend of increase noted above, and it was not substantiated by the sampling results that preceded or followed the March 2008 event. 


\section{E.2.1.15 Well MW1D}

Well MW1D is located west-northwest of the former CCC/USDA facility and approximately $135 \mathrm{ft}$ east of wells PWS2 and PWS3. Well MW1D is the closest upgradient monitoring point along the apparent migration pathway within the deep aquifer zone that is developed toward the public water supply wells when these wells are actively pumping. Well MW1D was constructed by the KDHE with a 20-ft screen. The concentration-versus-time graph for well MW1D is in Figure E.17.

Figure E.17 indicates that the concentrations of carbon tetrachloride observed at well MW1D have remained well below the KDHE RBSL of $5.0 \mu \mathrm{g} / \mathrm{L}$ throughout the period of record. Maximum concentrations of $1.0 \mu \mathrm{g} / \mathrm{L}$ and $1.2 \mu \mathrm{g} / \mathrm{L}$ were identified, respectively, during the July 2006 and April 2007 sampling events (with the three-well-volume purge method). The carbon tetrachloride concentrations observed during all subsequent sampling events (from November 2007 to September-October 2009) have ranged from < $0.1 \mu \mathrm{g} / \mathrm{L}$ (ND) to $0.3 \mu \mathrm{g} / \mathrm{L}$, showing no clear pattern of increase or decrease with time.

\section{E.2.2 Individual Review of Wells Completed in the Intermediate Aquifer Zone}

\section{E.2.2.1 Well MW10S}

Well MW10S is located in the east central portion of the former CCC/USDA grain storage facility. The well has a 10-ft screen. Because of the small number of data points specific to the intermediate zone and the hydrologic variables discussed in Section 4.2, the specific groundwater flow and contaminant migration patterns at this and all other monitoring points in the intermediate aquifer zone cannot be determined from presently available data. The concentration-versus-time graph for well MW10S is in Figure E.18.

The identified carbon tetrachloride values at MW10S have been significantly above the KDHE RBSL value of $5.0 \mu \mathrm{g} / \mathrm{L}$ throughout the period of monitoring. Figure E.18 suggests an inconsistency, however, in the measured values obtained at well MW10S by using the threewell-volume purge method versus the low-flow sampling method. Contaminant concentrations of $20 \mu \mathrm{g} / \mathrm{L}$ and $11 \mu \mathrm{g} / \mathrm{L}$ were determined for this well, respectively, during the March and November 2007 sampling events, which were conducted with the three-well-volume purge 
method. The results of all later sampling events, performed by using the low-flow technique, have varied erratically but have been consistently greater (ranging from $49 \mu \mathrm{g} / \mathrm{L}$ to $78 \mu \mathrm{g} / \mathrm{L}$ ) than results for the earlier events. The low-flow results for well MW10S represent the highest carbon tetrachloride concentrations identified to date in the groundwater at Barnes, in any aquifer interval.

The linear regression line in Figure E.18 suggests a possible trend of increasing carbon tetrachloride concentrations at well MW10S; however, the calculated statistical fit of this line to the measurement data is very poor, because of the relatively large variations in measured values that have been documented at this well.

\section{E.2.2.2 Well MW12M}

Well MW12M is located north-northwest of the former CCC/USDA facility and directly east of public supply wells PWS2 and PWS3. The well is constructed with a 10-ft screen. The concentration-versus-time graph for well MW12M is in Figure E.19.

The identified carbon tetrachloride values at MW12M have been significantly above the KDHE RBSL value of $5.0 \mu \mathrm{g} / \mathrm{L}$ throughout the period of record. Consistent carbon tetrachloride concentrations of $18 \mu \mathrm{g} / \mathrm{L}$ to $20 \mu \mathrm{g} / \mathrm{L}$ were identified at this well during the first three sampling events (in April and November 2007 and March 2008). From March 2008 to September-October 2009 , concentrations ranging from $18 \mu \mathrm{g} / \mathrm{L}$ to $28 \mu \mathrm{g} / \mathrm{L}$ were identified, with values of $25 \mu \mathrm{g} / \mathrm{L}$ to $28 \mu \mathrm{g} / \mathrm{L}$ occurring during the most recent sampling events (in March, June, and SeptemberOctober 2009). The relative consistency of these most recent values significantly influences the calculated linear regression line for this data set (Figure E.19), suggesting a possible trend of increasing concentrations in this well.

\section{E.2.2.3 Well MW11M}

Well MW11M is located west-northwest of the former CCC/USDA facility and eastsoutheast of wells PWS2 and PWS3. Well MW11M has a 10-ft screen. The concentrationversus-time graph for this well is in Figure E.20. 
The carbon tetrachloride concentrations observed at well MW11M have remained below the KDHE RBSL value of $5.0 \mu \mathrm{g} / \mathrm{L}$ throughout the monitoring program. A maximum contaminant level of $3.7 \mu \mathrm{g} / \mathrm{L}$ was detected during the November 2007 monitoring event; since that time, the measured concentrations have shown a steady decline with time, to levels that were below the instrumental detection limit of $0.1 \mu \mathrm{g} / \mathrm{L}$ (ND) in the two most recent sampling events (June and September-October 2009).

\section{E.2.2.4 Well MW13S}

Well MW13S lies west-northwest of the former CCC/USDA facility and is approximately $400 \mathrm{ft}$ due east of wells PWS2 and PWS3. Well MW13S has a 10-ft screen. The concentration-versus-time graph for this well is in Figure E.21.

The levels of carbon tetrachloride detected at well MW13S have been above the KDHE RBSL value of $5.0 \mu \mathrm{g} / \mathrm{L}$ throughout the period of record. A maximum carbon tetrachloride concentration of $21 \mu \mathrm{g} / \mathrm{L}$ was identified in this well in April 2007. Figure E.21 indicates that the carbon tetrachloride levels in this well have decreased fairly steadily since that time, reaching a minimum (to date) of $12 \mu \mathrm{g} / \mathrm{L}$ in September-October 2009.

\section{E.2.2.5 Well MW17}

Well MW17 is located west-northwest of the former CCC/USDA facility and, in the intermediate aquifer zone, is the closest monitoring point to public supply wells PWS2 and PWS3. Well MW17 is approximately $135 \mathrm{ft}$ east of wells PWS2 and PWS3. The concentrationversus-time graph for well MW17 is in Figure E.22.

The concentrations of carbon tetrachloride in well MW17 have remained well below the KDHE RBSL of $5.0 \mu \mathrm{g} / \mathrm{L}$ throughout the monitoring period. No carbon tetrachloride was detected by the three-well-volume purge method during the March and November 2007 sampling events. Slowly increasing concentrations, ranging from $0.3 \mu \mathrm{g} / \mathrm{L}$ to $1.0 \mu \mathrm{g} / \mathrm{L}$, were detected with the low-flow sampling method during monitoring in March 2008 to June 2009; however, no

carbon tetrachloride was detected in September-October 2009, suggesting that no continuing trend in the measured values can presently be identified. 


\section{E.2.3 Individual Review of the Public Supply Wells}

The groundwater level data discussed in Section 4.1 demonstrate that the pumping of public supply wells PWS2 and PWS3 imparts drawdown in the monitoring (and private) wells completed in both the intermediate and deep aquifer zones. Although the specific construction details of the public water supply wells are uncertain, this observation confirms that these wells are capable of obtaining groundwater from both of the identified aquifer intervals.

\section{E.2.3.1 Well PWS2}

Well PWS2 is the more northern of the two public supply wells at Barnes. The well is located approximately $135 \mathrm{ft}$ west-northwest of monitoring wells MW1D (in the deep aquifer zone) and MW17 (in the intermediate aquifer zone). The reported depth of the well is $155 \mathrm{ft}$. The positions of the screen and gravel pack in PWS2 are unknown. The concentration-versus-time graph for well PWS2 is in Figure E.23.

Figure E.23 shows that no carbon tetrachloride was detected (at the instrumental detection limit of $0.1 \mu \mathrm{g} / \mathrm{L}$ ) in several sampling events conducted at this well from March 2007 to March 2008. From July 2008 to June 2009, carbon tetrachloride was identified in the groundwater at well PWS2 at concentrations ranging from $0.8 \mu \mathrm{g} / \mathrm{L}$ to $1.7 \mu \mathrm{g} / \mathrm{L}$ (in October 2008); however, no distinct pattern of concentration increase or decrease is apparent in the analytical results during this period. No carbon tetrachloride was again detected in the most recent sampling of this well, in September-October 2009. The results of the linear regression depicted in Figure E.23 empirically suggest a pattern of slightly increasing concentrations at this

well with time; however, the potential long-term significance of this apparent trend cannot be determined in light of the September-October 2009 analysis.

\section{E.2.3.2 Well PWS3}

Well PWS3 is the more southern of the two public supply wells at Barnes. The well is located approximately $135 \mathrm{ft}$ west-southwest of monitoring wells MW1D (in the deep aquifer zone) and MW17 (in the intermediate aquifer zone). The reported depth of the well is $160 \mathrm{ft}$. As is the case for well PWS2, the positions of the screen and gravel pack in PWS3 are unknown. The concentration-versus-time graph for well PWS3 is in Figure E.24. 
Carbon tetrachloride was identified at well PWS3 at a trace level $(0.2 \mu \mathrm{g} / \mathrm{L})$ on two isolated occasions: in March 2007 and July 2008 (Figure E.24). No carbon tetrachloride was detected during any other sampling event at this well.

\section{E.2.4 Spatial Distribution of Possible Concentration Trends for the Deep and Intermediate Aquifer Zones}

Sections E.2.1 and E.2.2 demonstrate that both the absolute carbon tetrachloride concentrations and the temporal variations in these concentrations vary significantly from location to location within the deep and intermediate aquifer zones at Barnes (Figures E.1-E.22). To summarize these relationships, Figures E.25 and E.26 schematically represent the apparent areal distribution of concentration trends identified, respectively, in the intermediate and deep aquifer zone wells. For each well, the arrow indicates the nature of the calculated data trend (increasing, decreasing, or no distinct trend), and the posted value represents the empirical rate of concentration change (in $\mu \mathrm{g} / \mathrm{L}$ per year) determined from the slope of the regression line for that well. For the purposes of this evaluation, only trends displaying a relatively good statistical "fit" to the associated measurement data $\left(\mathrm{R}^{2} \geq 0.5\right)$ are illustrated.

As noted in Section E.1, it must be recognized that the apparent trends represented in Figures E.25 and E.26 are based on the relatively limited monitoring data (both in time and number of measurements per location) that are presently available; hence, these trends are subject to further evaluation and interpretation as additional monitoring data are accumulated over time.

\section{E.2.4.1 Trends for the Intermediate Aquifer Zone}

On the basis of the criteria outlined above, Figure E.25 suggests that three of the five currently monitored wells in the intermediate aquifer zone have shown relatively consistent concentration trends during the review period. Since 2007, the carbon tetrachloride concentrations at both MW13S and MW11M have declined to their current minimum values of $14 \mu \mathrm{g} / \mathrm{L}$, and $0.6 \mu \mathrm{g} / \mathrm{L}$, respectively. At well MW12S, increasing carbon tetrachloride levels have been observed during the period of record, reaching maximum concentrations of $25-28 \mu \mathrm{g} / \mathrm{L}$ in 2009. No clear trends of concentration increase or decrease are noted at intermediate-zone wells MW10S and MW17. 
Well MW10S is located at the former CCC/USDA facility. Although no distinct trend appears to exist for the carbon tetrachloride concentrations at this location, this well continues to return the highest concentrations of carbon tetrachloride in groundwater at any point (or aquifer interval) in the Barnes study area. As noted in Section 4.1, groundwater flow in the intermediate aquifer zone is believed to be influenced by both horizontal and vertical hydraulic gradients. In this zone, the flow shows relatively little apparent response to the pumping of wells PWS2 and PWS3. Figure E.25 illustrates, however, that well MW12S lies roughly along a potential line-ofsight pathway for groundwater flow and contaminant migration from the former CCC/USDA facility toward the public supply wells. The increasing concentrations with time observed at well MW12S might therefore empirically suggest potential movement of carbon tetrachloride within the intermediate aquifer zone from the former CCC/USDA facility toward these wells.

Wells MW17, MW13S, and MW11M also lie along the apparent line-of sight pathway from the former CCC/USDA facility toward the public water supply wells, and they represent the three observation points in the intermediate aquifer zone that are the closest to wells PWS2 and PWS3. Figure E.25 and Figures E.20-E.22 indicate that the carbon tetrachloride concentrations at these locations have decreased (MW11M and MW13S) or remained effectively stable (MW17) during the current monitoring program. The results from these wells therefore provide no evidence to date of increasing risk to the public supply wells as a result of potential lateral movement of carbon tetrachloride within the intermediate aquifer zone.

\section{E.2.4.2 Trends for the Deep Aquifer Zone}

Figure E.26 indicates that increasing concentration trends were identified at six monitoring well locations in the deep aquifer zone: at MW5, MW6D, MW8, MW13D, MW15S, and MW16S. Among these wells, monitoring points MW8 and MW5, located within and immediately adjacent to the former CCC/USDA facility, appear to exhibit the greatest inferred rate of concentration increase during the period of record. In conjunction with the observations noted in Section E.2.4.1, the increasing concentrations at MW8 and MW5 appear qualitatively consistent with possible downward and lateral contaminant migration from the area of higher concentrations detected at intermediate-zone well MW10S.

With one exception, the other wells that showed relatively consistent increases in their concentrations of carbon tetrachloride are located at greater distances to the east (MW6D), northeast (MW16S), and north (MW15S) of the former CCC/USDA facility. At each of these 
locations, both the absolute concentrations observed to date and the inferred rates of concentration increase are small in comparison to those noted at MW5 and MW8. Wells MW6D, MW16S, and MW15S all lie in the approximate direction of groundwater flow within the deep aquifer zone under the ambient hydraulic gradients observed when wells PWS2 and PWS3 are not actively pumping. The slight increases in concentrations detected in these wells are therefore qualitatively consistent with possible slow, lateral contaminant migration within the deep zone from the former CCC/USDA facility under non-pumping conditions. The observed concentrations in these wells remain below the KDHE RBSL of $5.0 \mu \mathrm{g} / \mathrm{L}$, and they pose no threat of potential future contamination to the Barnes public wells.

Figure E.26 shows that increasing carbon tetrachloride concentrations were also observed during the period of record at well MW13D. Well MW13D lies along the apparent groundwater and contaminant migration pathway from the former CCC/USDA facility toward wells PWS2 and PWS3 that is developed in the deep aquifer zone when these wells are actively pumping; however, no trends of increasing contaminant concentrations were identified in the other deepzone monitoring wells immediately upgradient or downgradient from MW13D. Comparison of Figures E.25 and E.26 qualitatively suggests that vertical migration of carbon tetrachloride from the overlying intermediate aquifer zone into the deep aquifer zone might in part account for the concentration trends observed at both MW13S (decreasing in the intermediate zone) and MW13D (increasing in the deep zone).

The results outlined above suggest a plausible mechanism for possible future contaminant level increases in the deep aquifer zone in the vicinity of well MW13D, directly upgradient of wells PWS2 and PWS3. As noted in Sections E.2.1.15, E.2.3.1, and E.2.3.2 and in Figure E.26, however, the results of the groundwater monitoring program at Barnes provide no evidence of increased contaminant levels at public wells PWS2 or PWS3, or at nearby monitoring well MW1D, as a result of the concentration changes that have been observed in the deep aquifer zone to date. 


\section{E.3 Summary and Recommendations}

\section{E.3.1 Summary}

The primary results of the trend analyses conducted for the groundwater monitoring data from Barnes are as follows:

- The concentrations of carbon tetrachloride observed in most of the monitoring wells in the intermediate and deep aquifer zones have shown relatively little significant change during the period of monitoring from 2006 to 2009.

- The concentration-versus-time profiles for three wells completed in the intermediate aquifer zone appear to display statistically significant trends of either increasing (MW12M) or decreasing (MW11M, MW13S) carbon tetrachloride levels for the period of monitoring.

- The concentration-versus-time profiles of eight wells completed in the deep aquifer zone appear to display statistically significant trends of either increasing (MW5, MW6D, MW8, MW13D, MW15S, MW16S) or decreasing (MW7, MW14D) carbon tetrachloride levels during the monitoring period.

- The concentration trends observed at the intermediate-zone and deep-zone wells noted above appear qualitatively consistent with the conceptual model of groundwater flow and contaminant migration developed for the Barnes hydrogeologic system.

- The results of the present analyses provide no clear evidence of an increased risk of contamination of the Barnes public water supply wells (PWS2 and PWS3) as a result of the concentration changes identified to date in both the intermediate and deep aquifer zones.

- Trends identified in the concentrations of carbon tetrachloride detected at intermediate-zone monitoring well MW13S and deep-zone well MW13D suggest a plausible mechanism for possible future contaminant level increases 
in the deep aquifer zone directly upgradient of wells PWS2 and PWS3, in the vicinity of well MW13D.

\section{E.3.2 Recommendations}

As noted in Section E.3.1, the present analyses demonstrate that the concentrations of carbon tetrachloride observed in most of the intermediate-zone and deep-zone monitoring wells have shown relatively little significant change during the period of monitoring from 2006 to 2009. This study has also shown that, in wells where changes in the concentrations of carbon tetrachloride have been observed over time, the identified rates of change in these concentrations are relatively slow in comparison to the sampling frequency that is currently employed in the monitoring of this site (twice yearly for monitoring and private wells and quarterly for public water supply wells).

On the basis of these findings, we recommend that sampling be suspended in a number of wells, reducing the active monitoring network to the set of wells identified in Table E.1.

We further recommend a change in monitoring frequency to annual for the monitoring wells identified in Table E.1 and to semi-annual for the public water supply wells. We propose to coordinate sampling schedules for the public wells so that the annual sampling by the city of Barnes serves as one of the two semi-annual events and our sampling serves as the other. 
TABLE E.1 Monitoring wells proposed for annual monitoring at Barnes, with carbon tetrachloride concentration trends. ${ }^{a}$

\begin{tabular}{|c|c|c|c|c|}
\hline \multirow[b]{2}{*}{ Well } & \multirow[b]{2}{*}{ Location } & \multirow[b]{2}{*}{ Trend $^{\mathrm{b}}$} & \multicolumn{2}{|c|}{ Carbon Tetrachloride $(\mu \mathrm{g} / \mathrm{L})$} \\
\hline & & & $\begin{array}{c}\text { Range, } \\
2007-2009\end{array}$ & $\begin{array}{l}\text { Most Recent, } \\
\text { Sep-Oct } 2009\end{array}$ \\
\hline \multicolumn{5}{|c|}{ Intermediate-Zone Wells } \\
\hline MW10S & On former CCC/USDA property & Highest levels; no clear trend & $11-76$ & 53 \\
\hline MW12M & On possible migration path & Increasing & $18-28$ & 26 \\
\hline MW13S & On possible migration path & Decreasing & $12-21$ & 12 \\
\hline MW17 & Public water supply sentinel well & No clear trend & ND-1.0 & ND \\
\hline \multicolumn{5}{|c|}{ Deep-Zone Wells } \\
\hline MW8 & On former CCC/USDA property & Increasing & $14-29$ & 29 \\
\hline MW10D & On former CCC/USDA property & Possibly decreasing & $2.4-6.3$ & 4.3 \\
\hline MW13D & On pumping-induced migration path & Increasing & $3.5-11$ & 7.2 \\
\hline MW1D & Public water supply sentinel well & No clear trend & ND-1.2 & $0.3 \mathrm{Jc}$ \\
\hline \multicolumn{5}{|c|}{ Background Well } \\
\hline MW2D & North of public supply wells & Consistently uncontaminated & ND & ND \\
\hline
\end{tabular}

a Twice yearly sampling is proposed for the public water supply wells, to be shared with the city of Barnes.

b Trend based on results of trend analysis.

c Qualifier J indicates an estimated concentration below the method quantitation limit of $1.0 \mu \mathrm{g} / \mathrm{L}$. 
Barnes MW16S

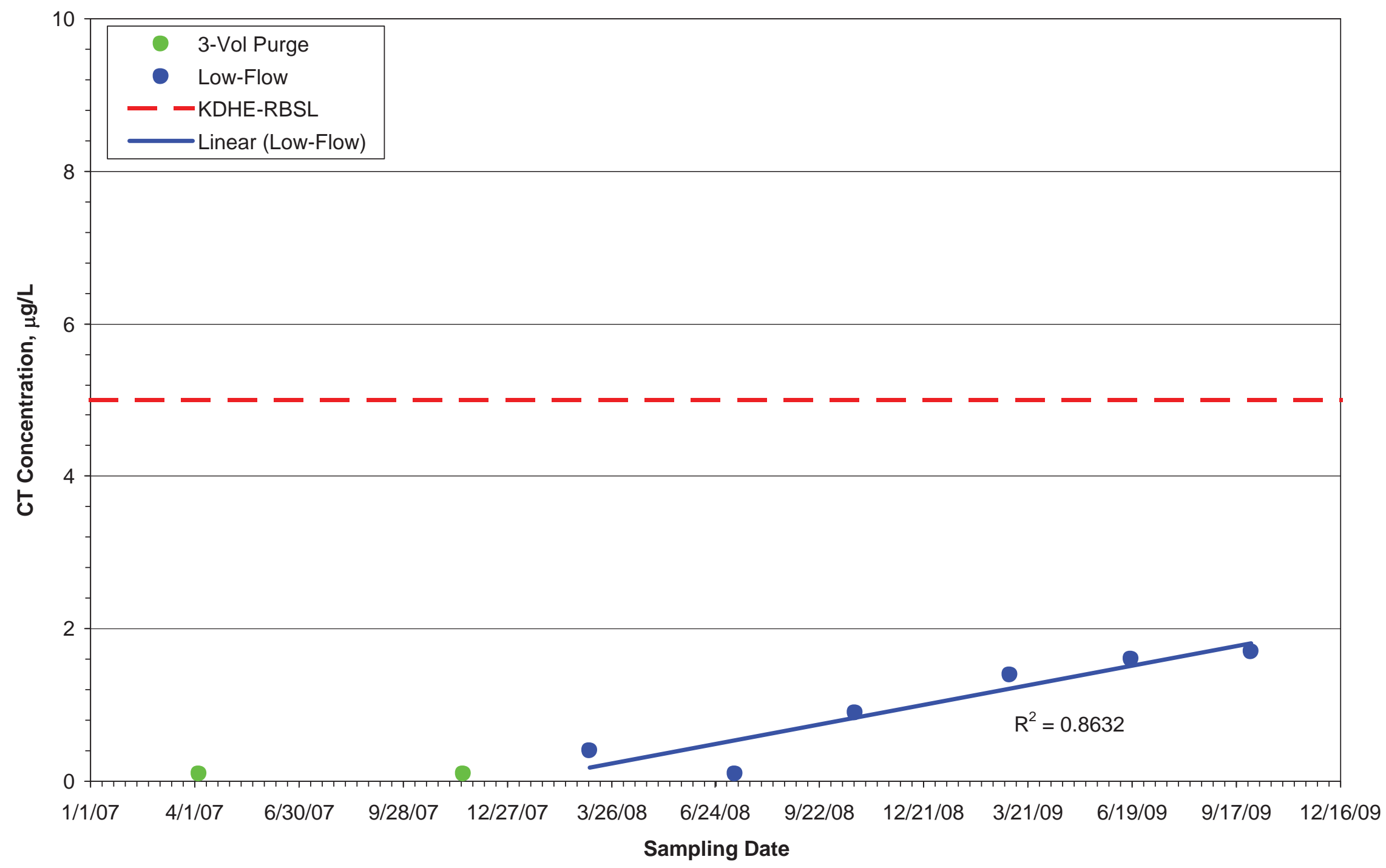

FIGURE E.1 Plot of concentration versus time for deep-zone well MW16S. 
Barnes MW6S

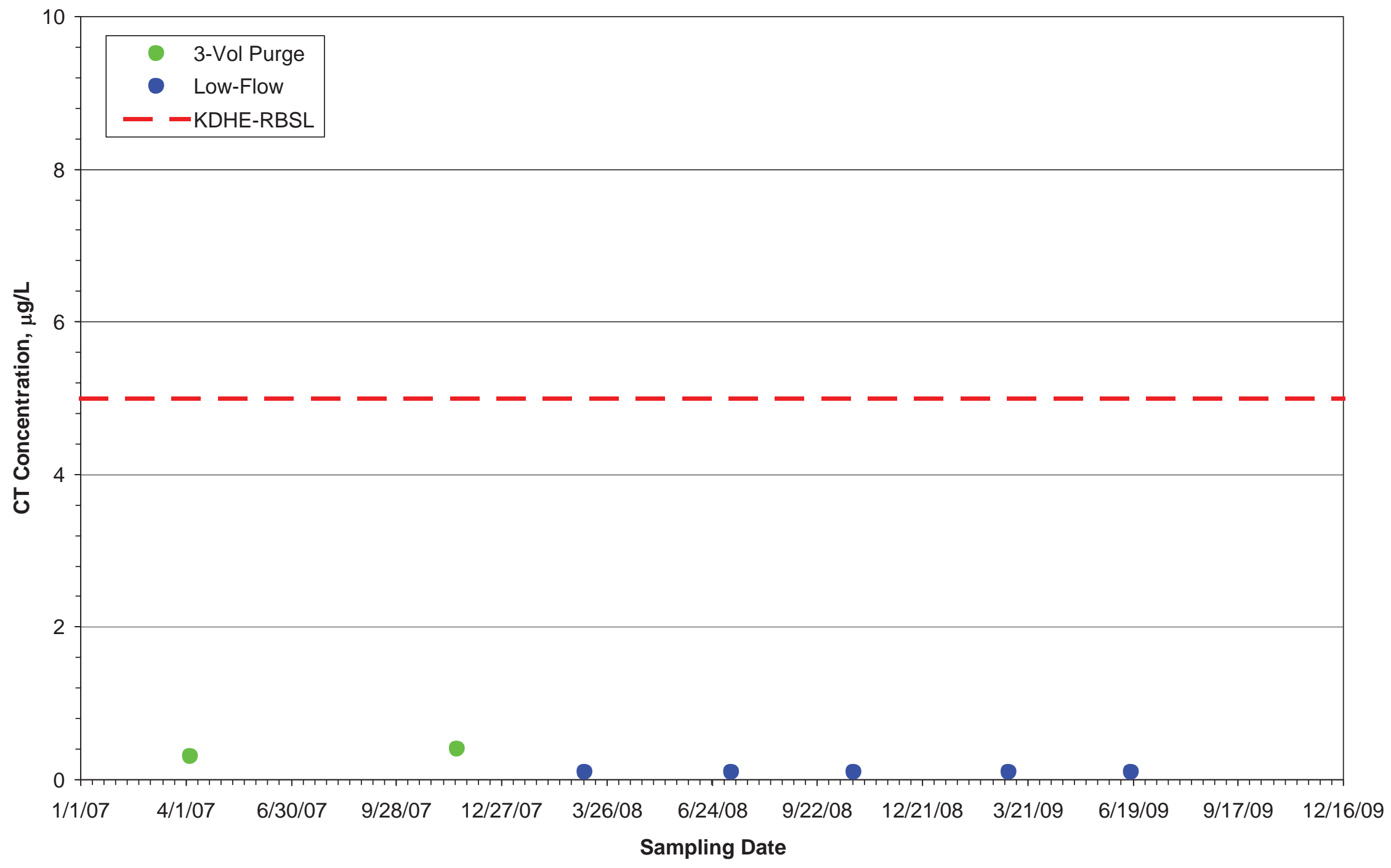

FIGURE E.2 Plot of concentration versus time for deep-zone well MW6S. 
Barnes MW6D

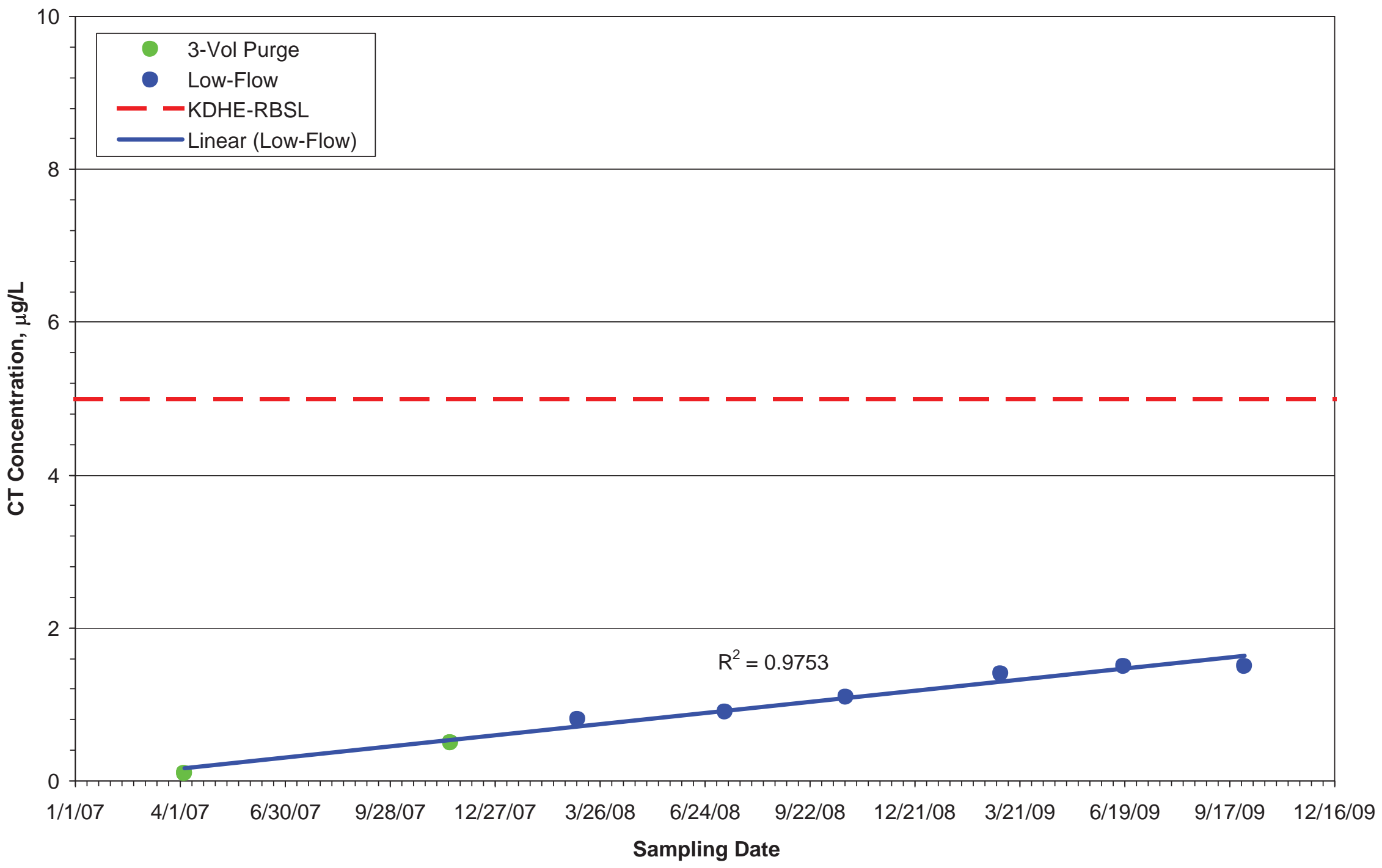

FIGURE E.3 Plot of concentration versus time for deep-zone well MW6D. 
Barnes MW7

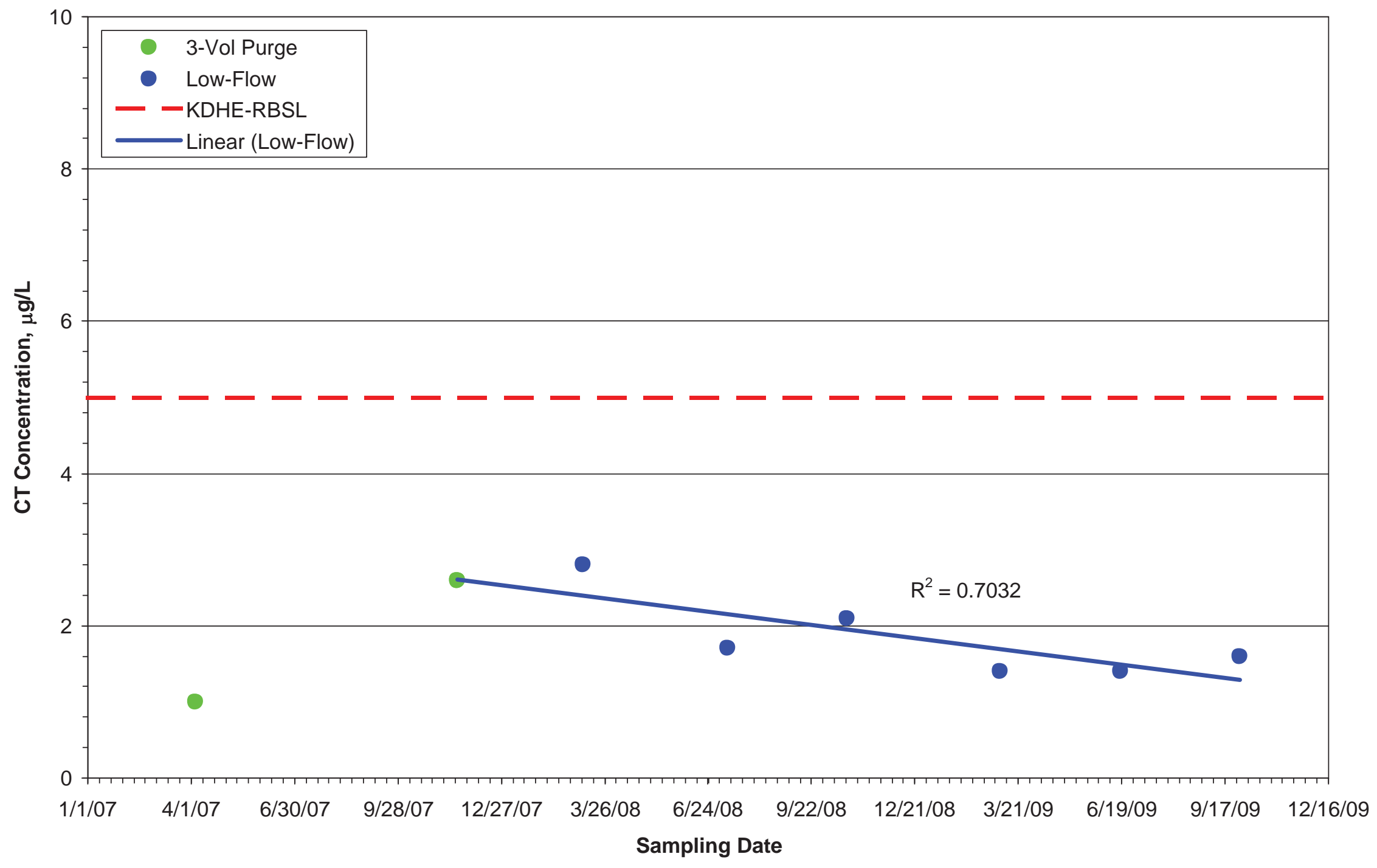

FIGURE E.4 Plot of concentration versus time for deep-zone well MW7. 


\section{Barnes MW5}

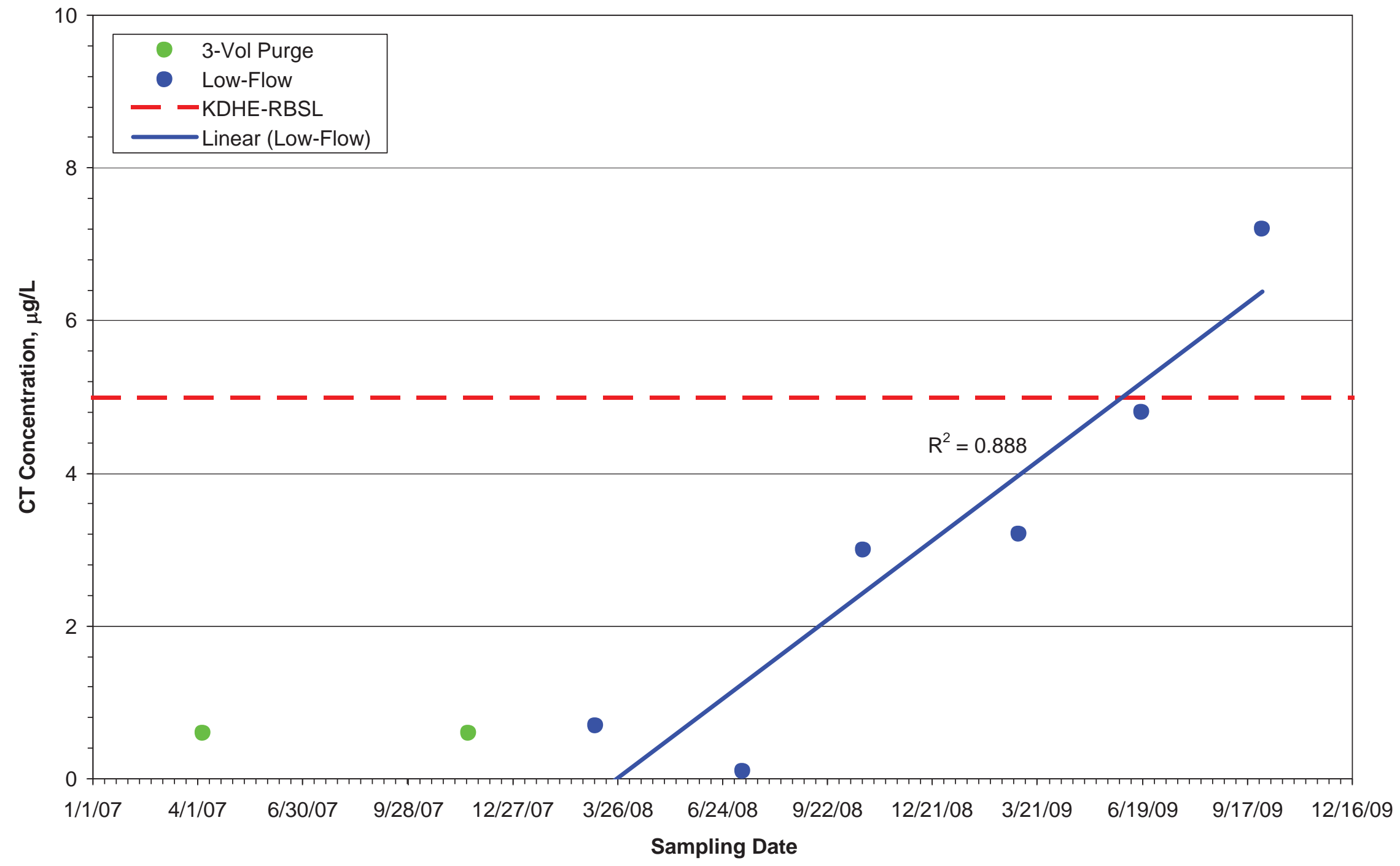

FIGURE E.5 Plot of concentration versus time for deep-zone well MW5. 


\section{Barnes MW15S}

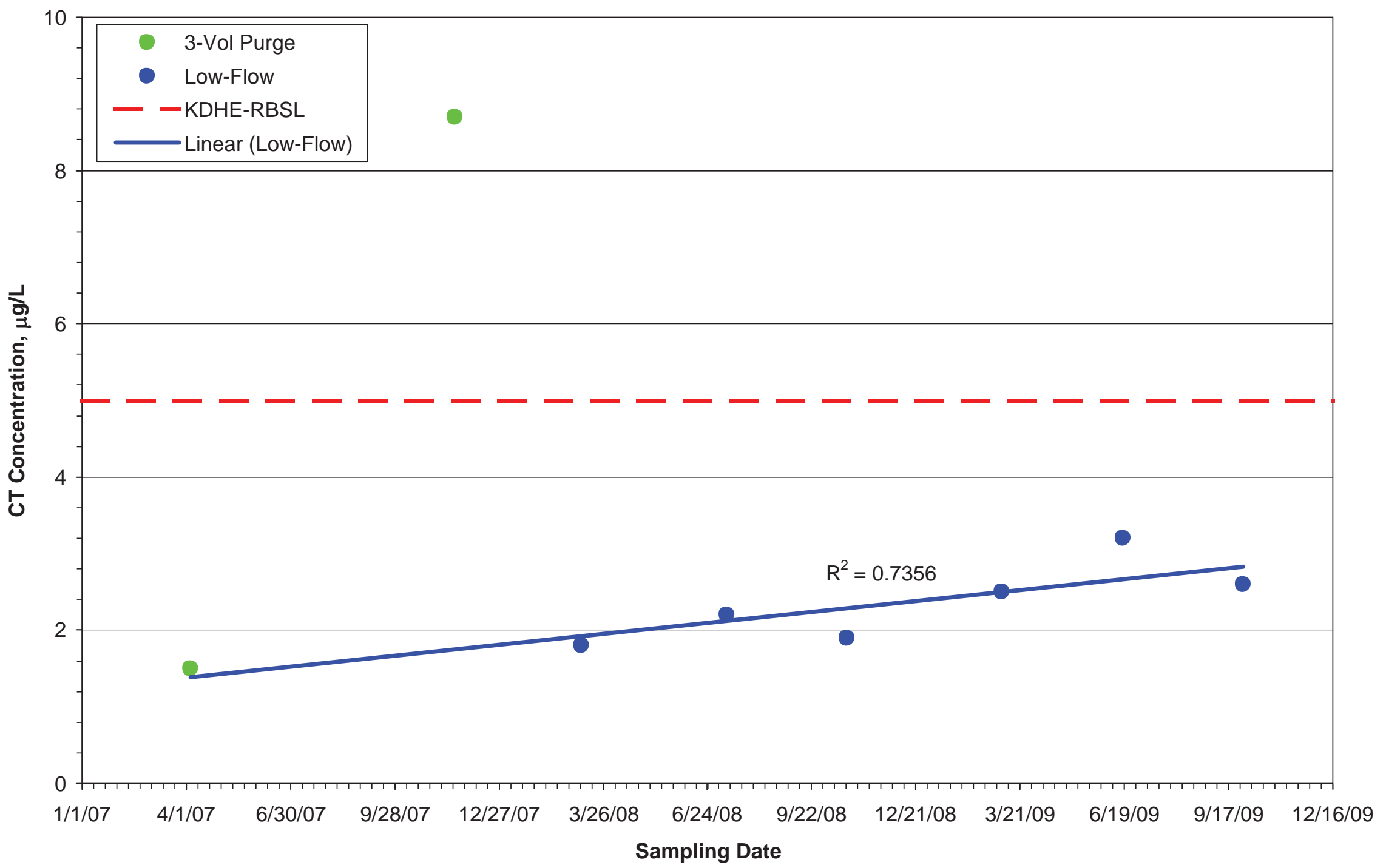

FIGURE E.6 Plot of concentration versus time for deep-zone well MW15S. 
Barnes Oentrich Private Well

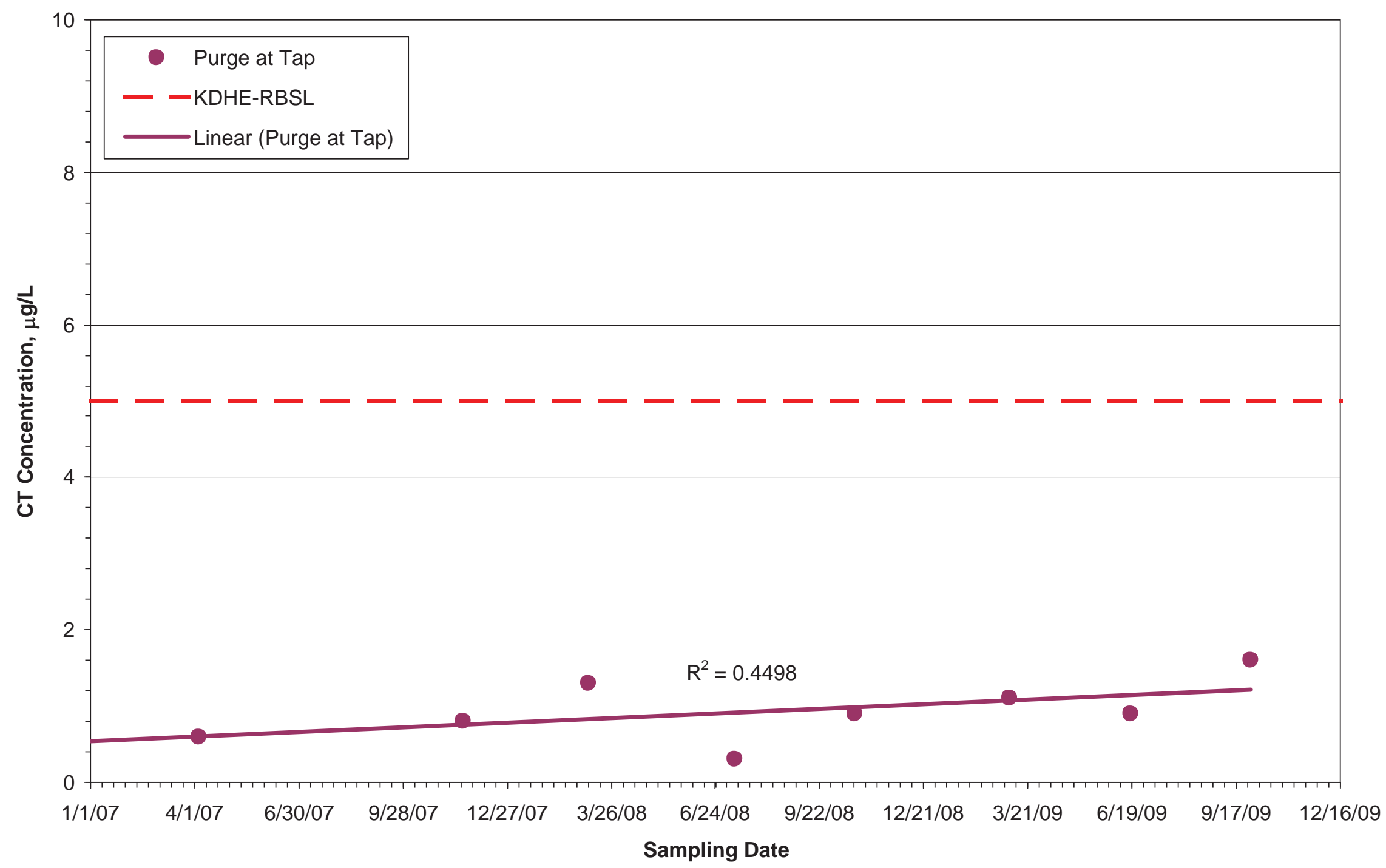

FIGURE E.7 Plot of concentration versus time for the Oentrich private well. 
Barnes MW10D

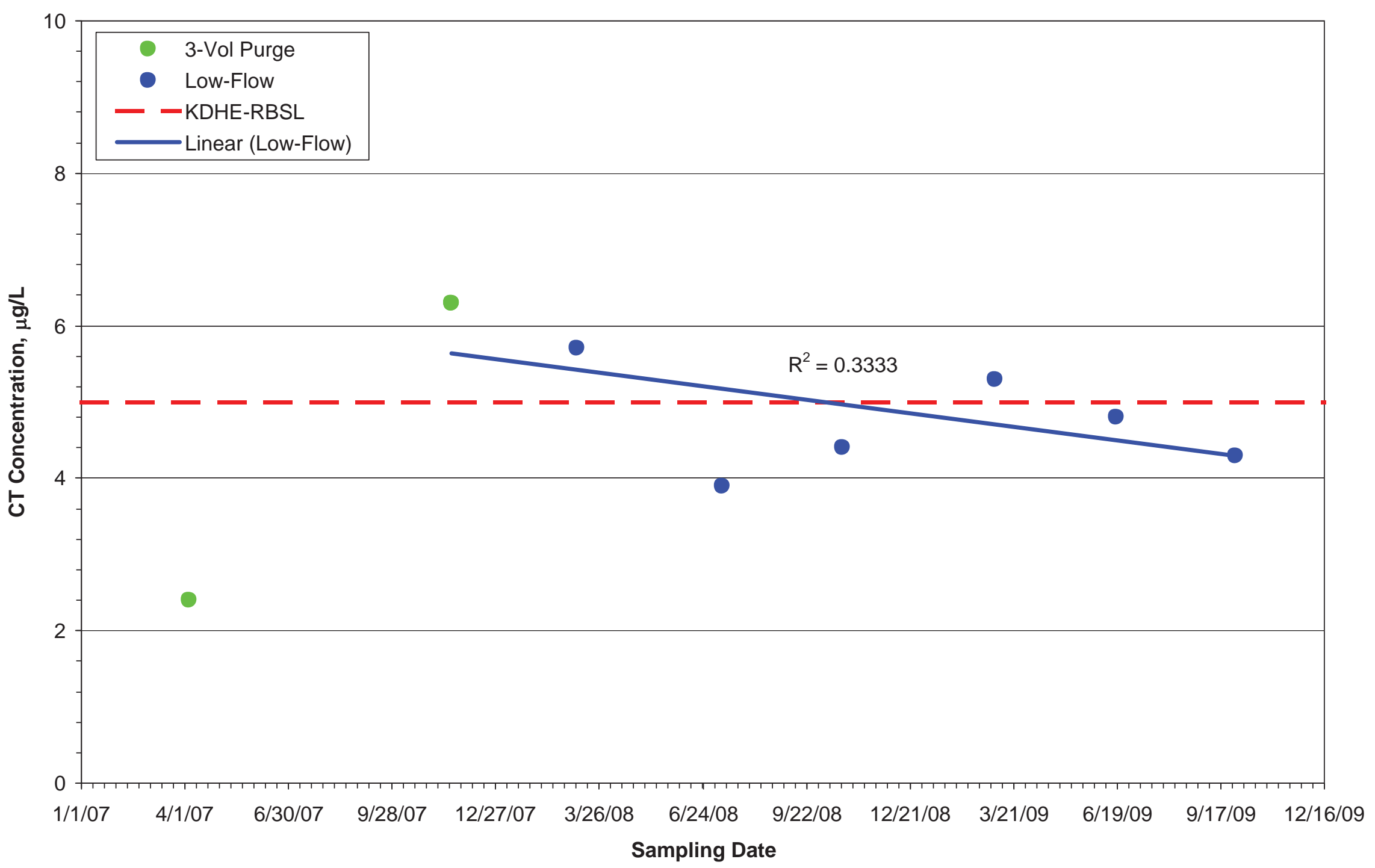

FIGURE E.8 Plot of concentration versus time for deep-zone well MW10D. 


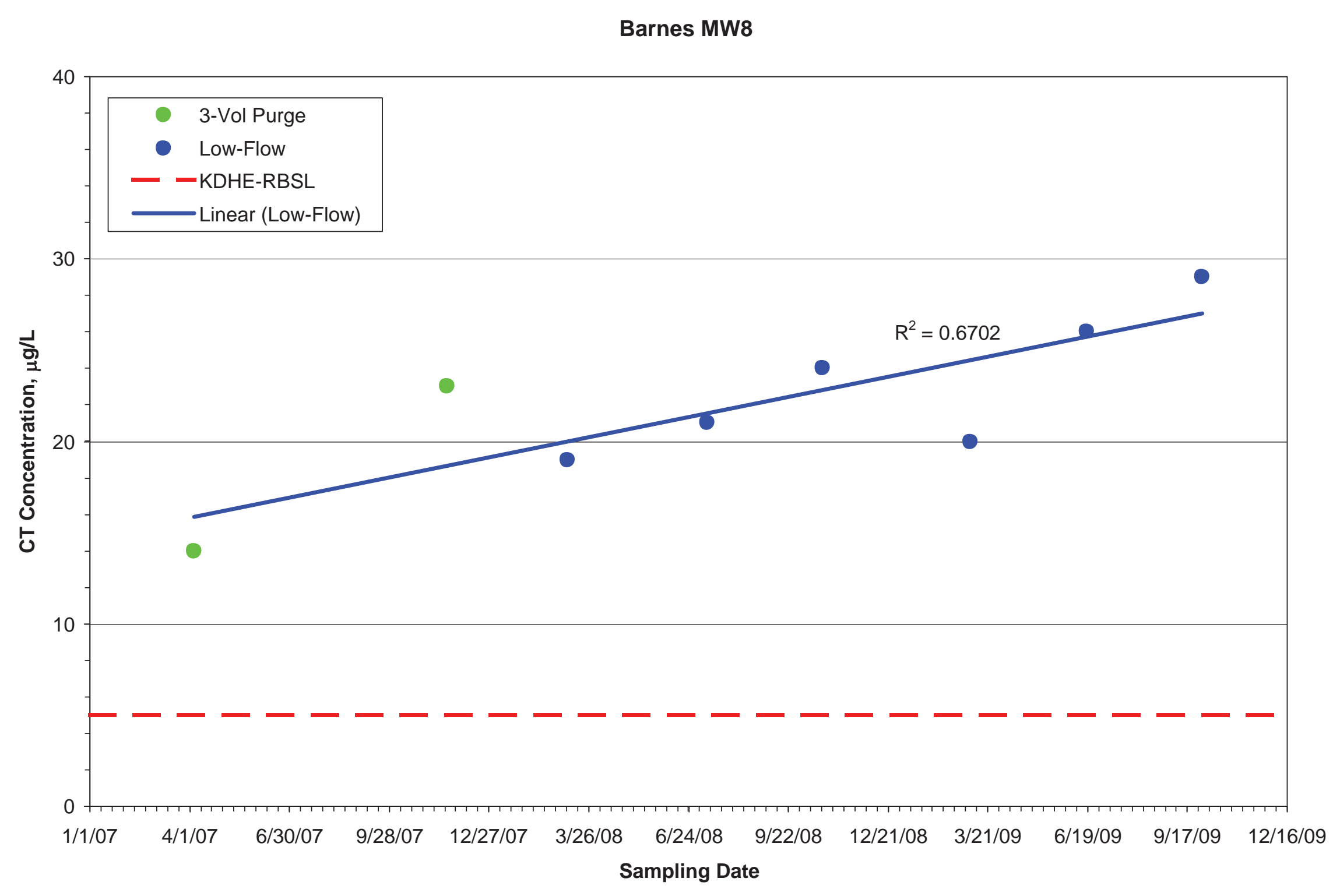

FIGURE E.9 Plot of concentration versus time for deep-zone well MW8. 
Barnes MW4D

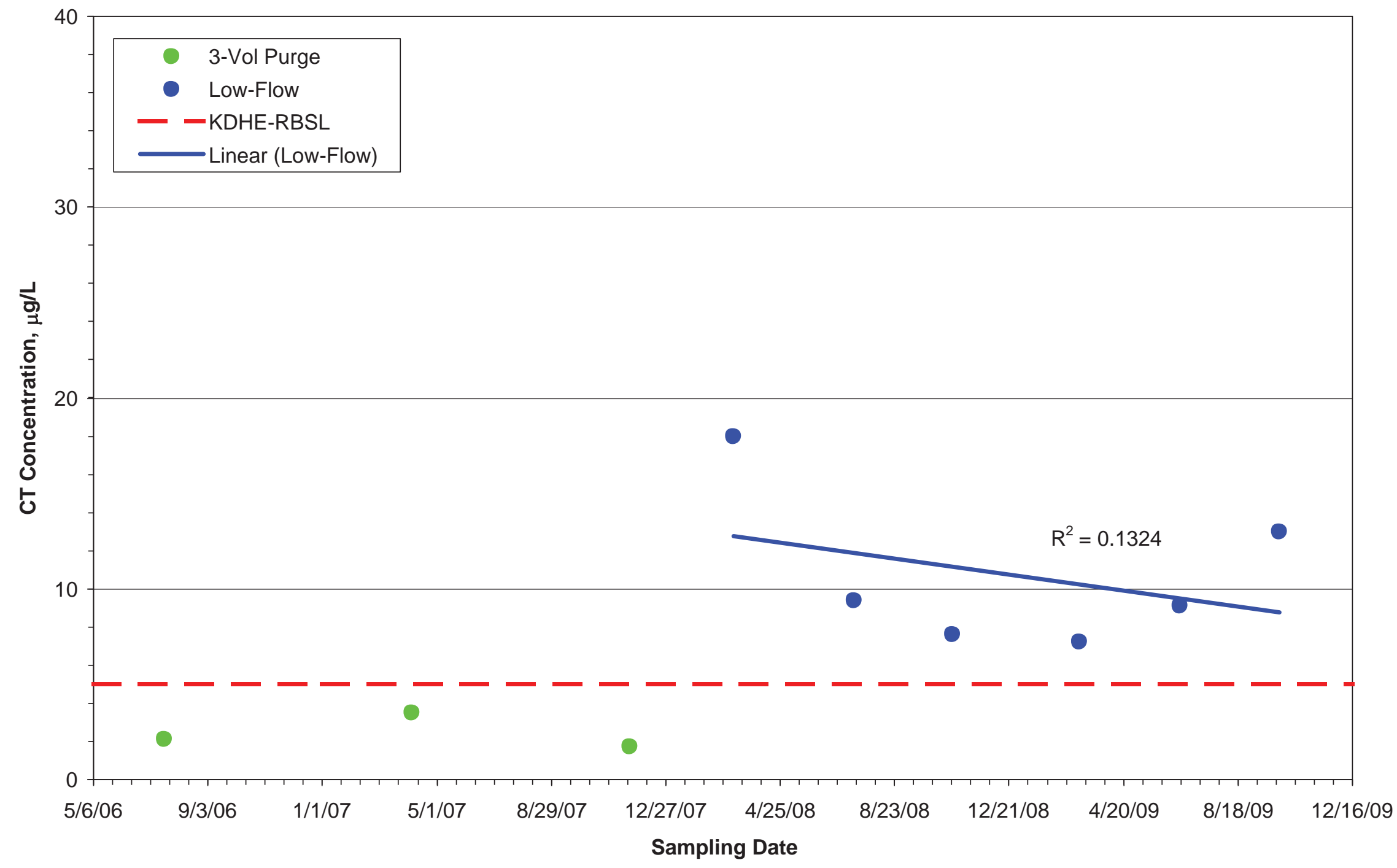

FIGURE E.10 Plot of concentration versus time for deep-zone well MW4D. 


\section{Barnes MW9}

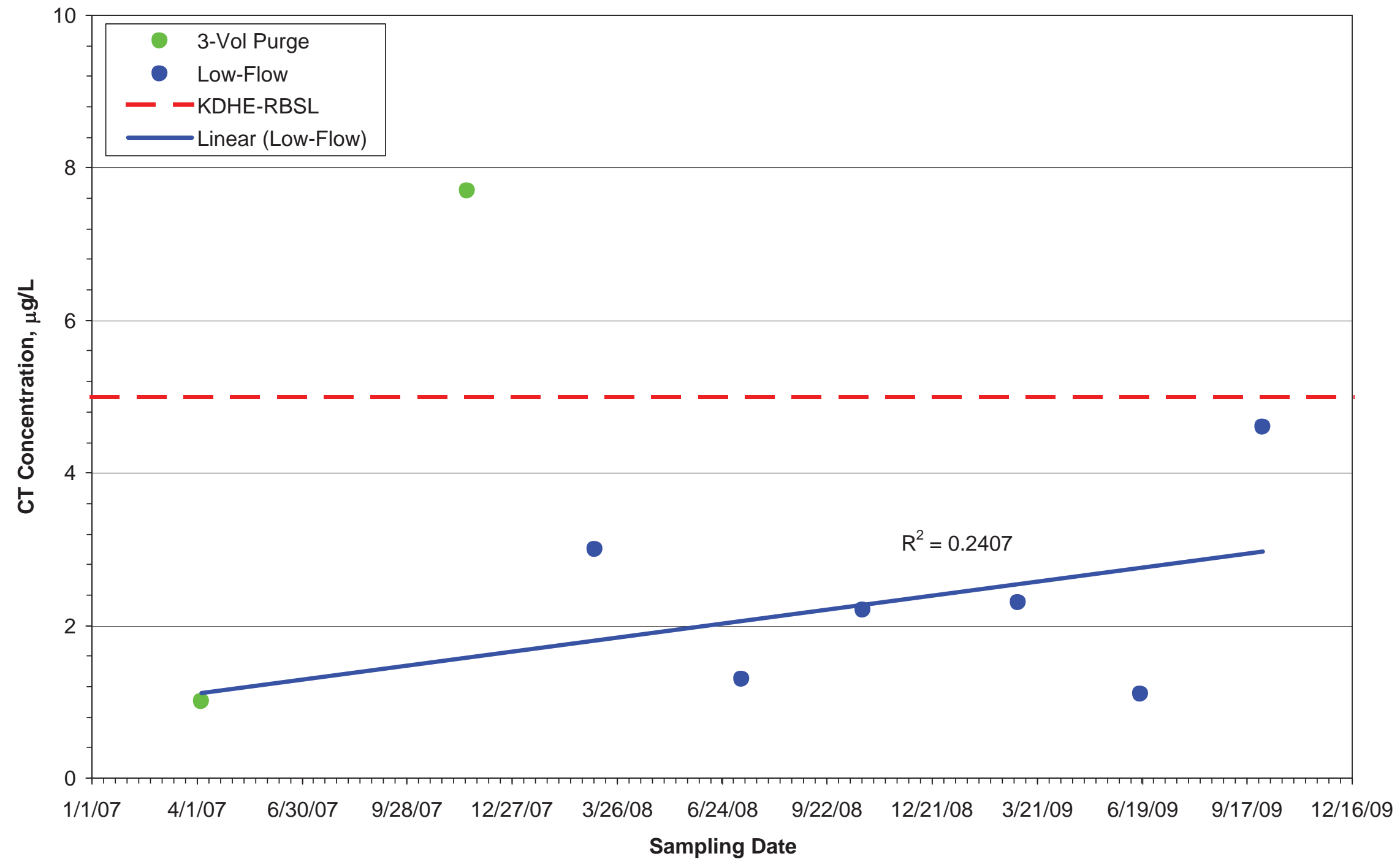

FIGURE E.11 Plot of concentration versus time for deep-zone well MW9. 
Barnes MW12D

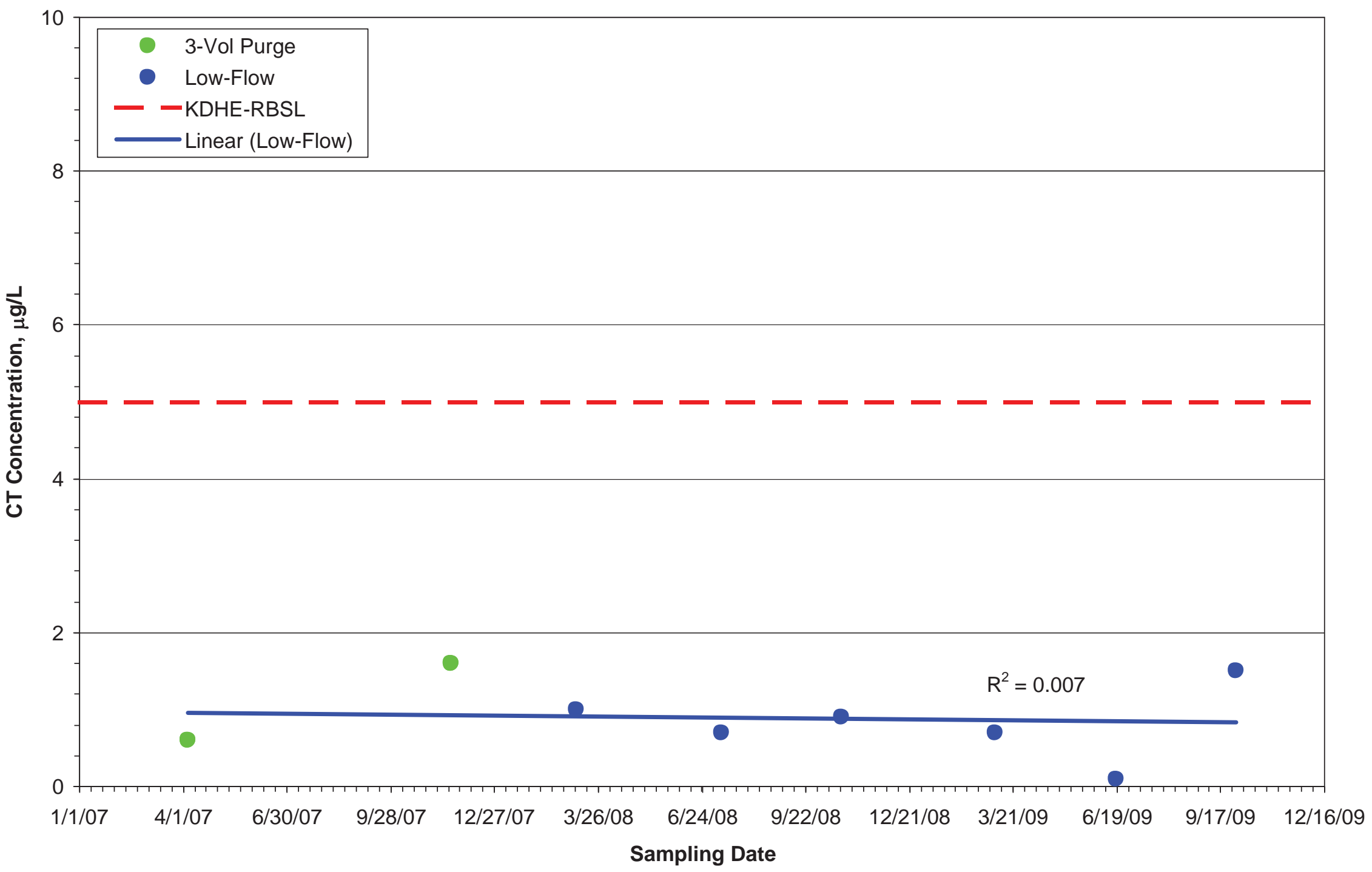

FIGURE E.12 Plot of concentration versus time for deep-zone well MW12D. 
Barnes MW11D

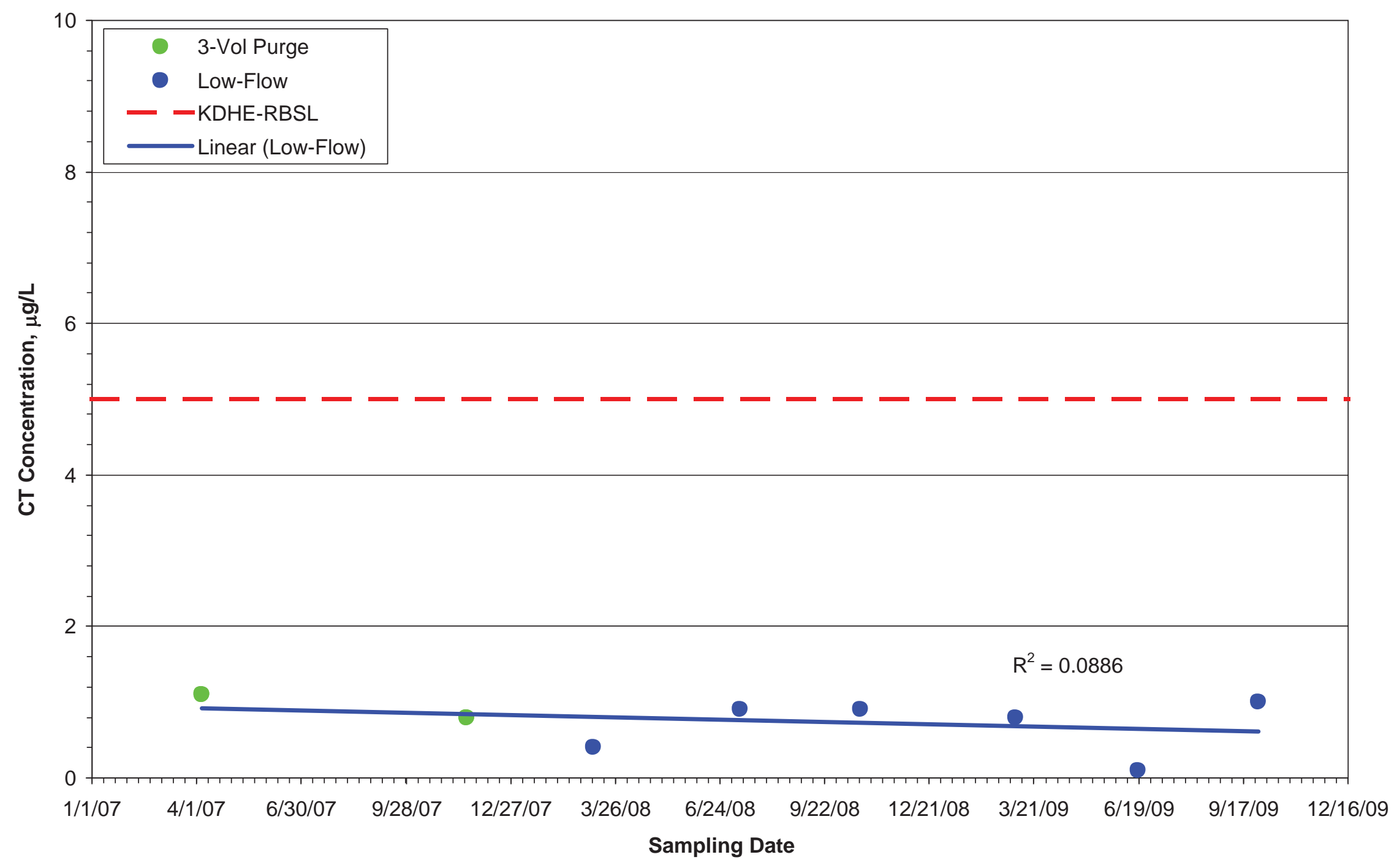

FIGURE E.13 Plot of concentration versus time for deep-zone well MW11D. 
Barnes MW14S

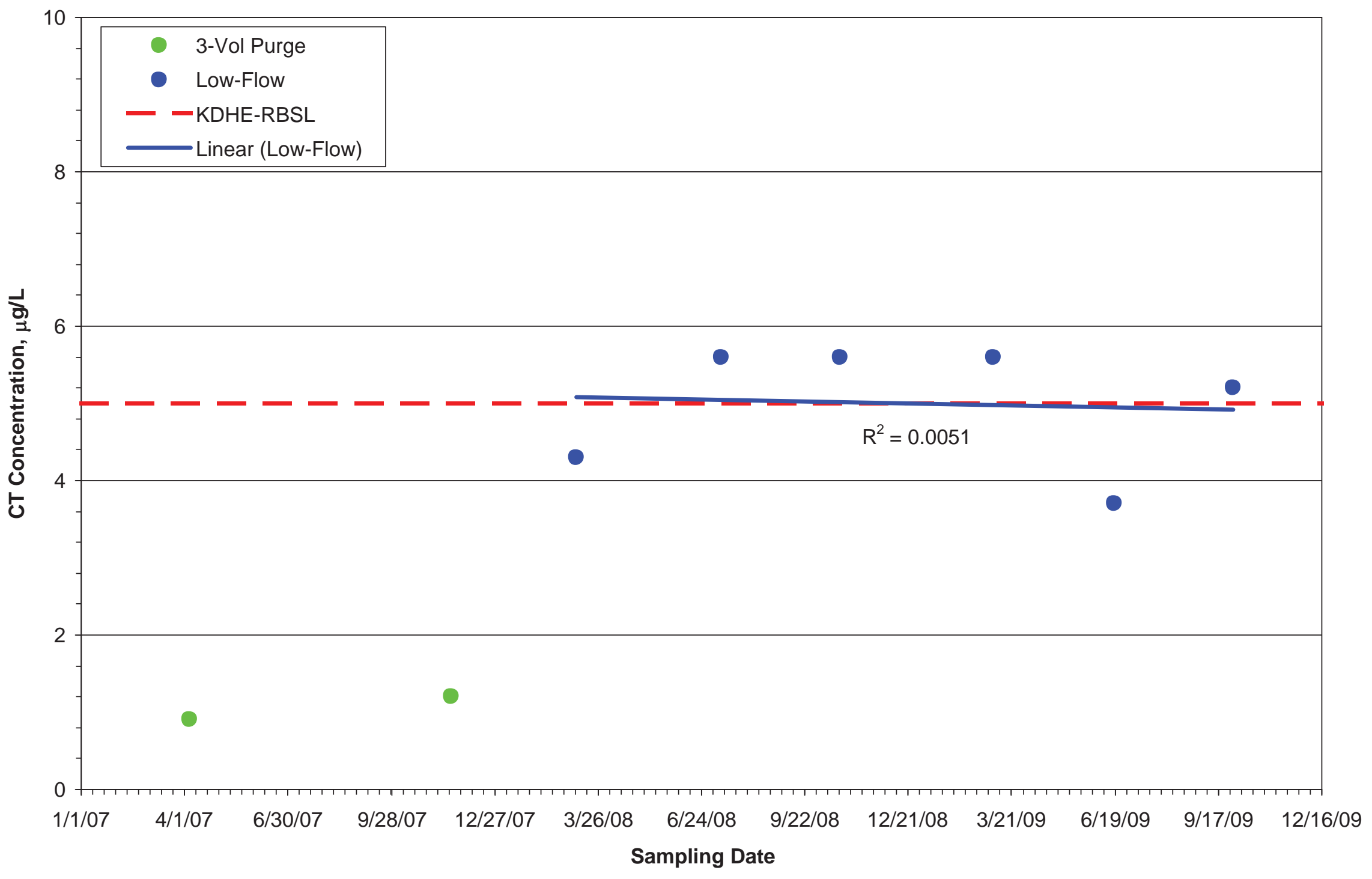

FIGURE E.14 Plot of concentration versus time for deep-zone well MW14S. 
Barnes MW14D

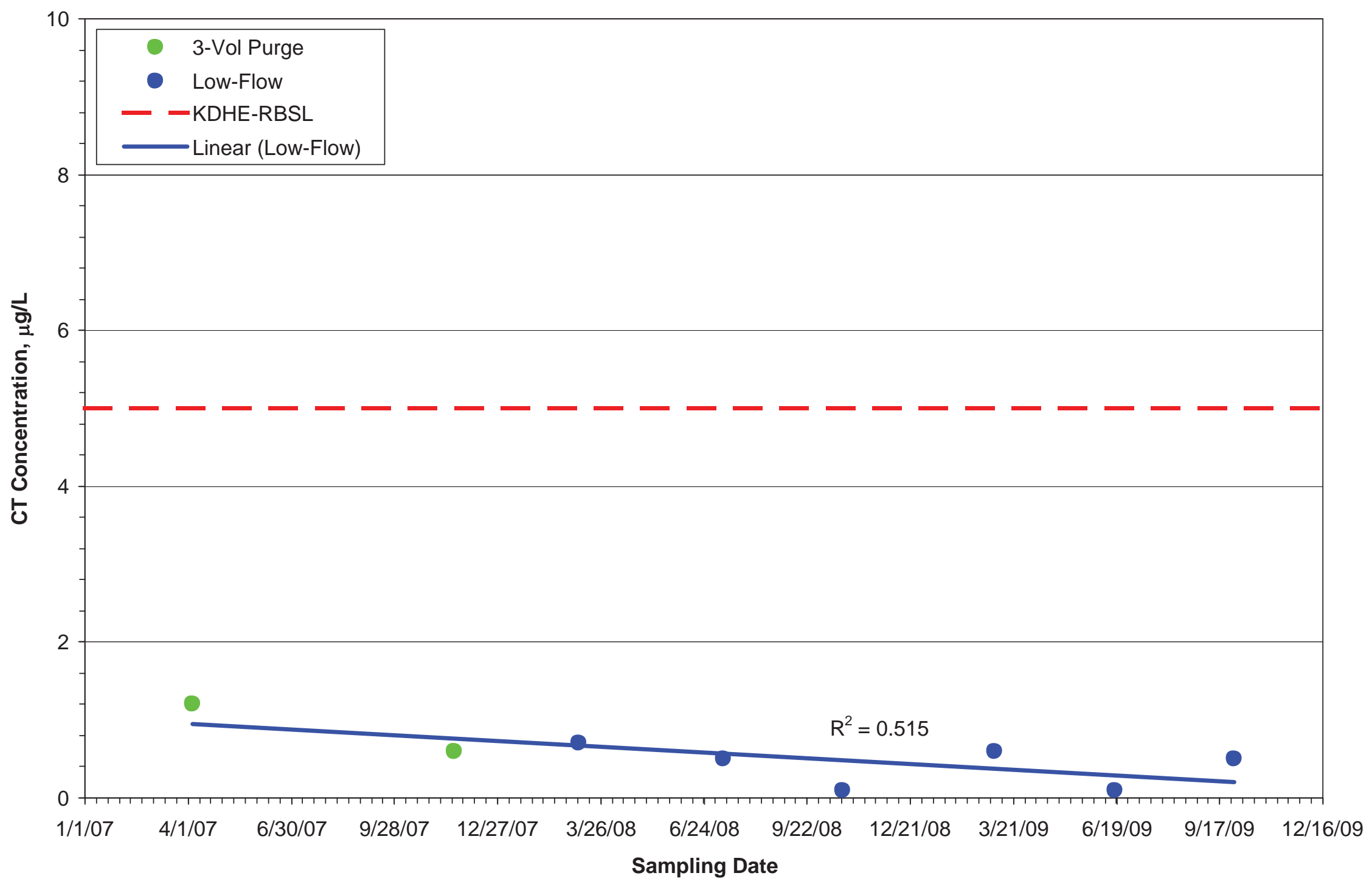

FIGURE E.15 Plot of concentration versus time for deep-zone well MW14D. 
Barnes MW13D

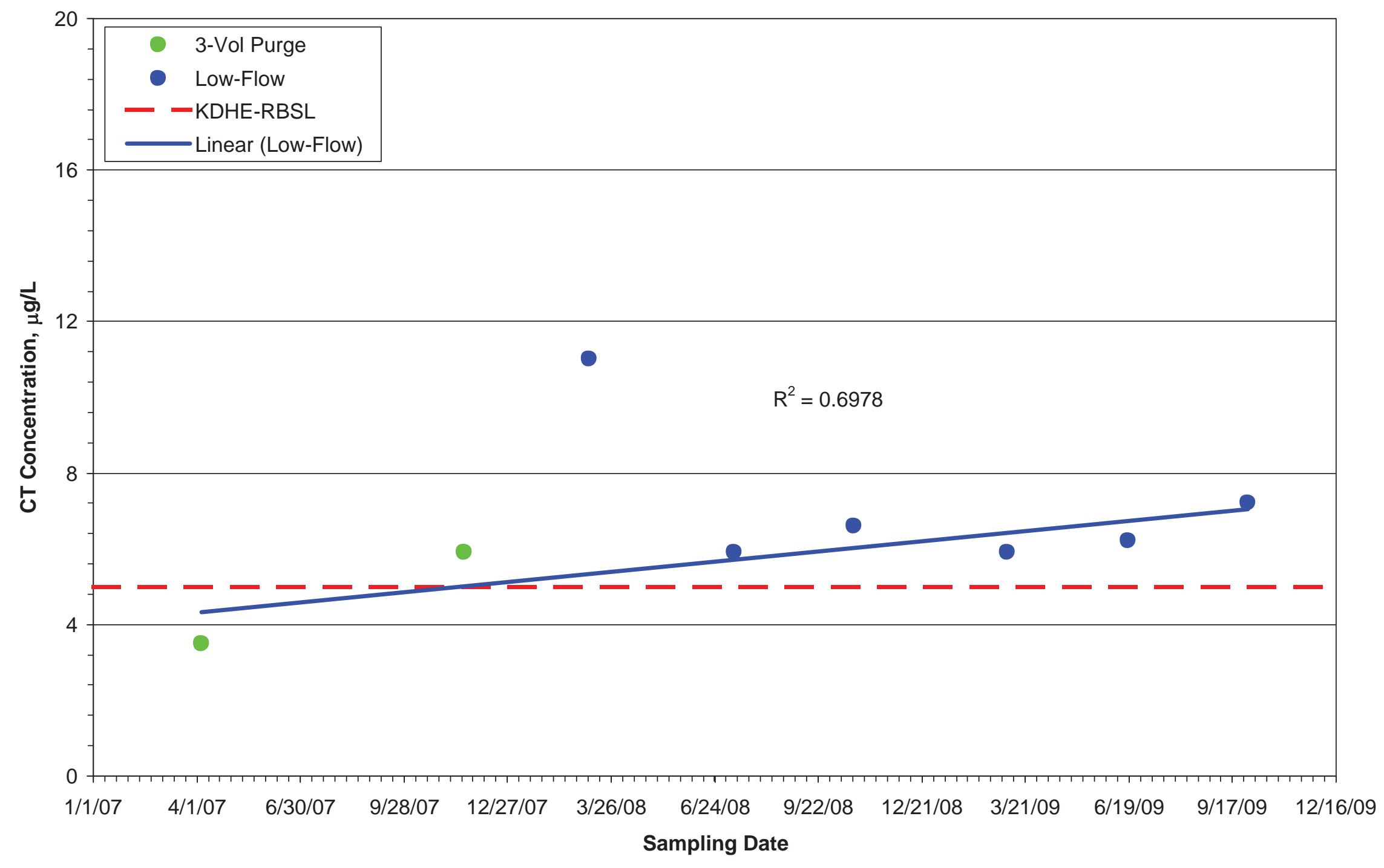

FIGURE E.16 Plot of concentration versus time for deep-zone well MW13D. 
Barnes MW1D

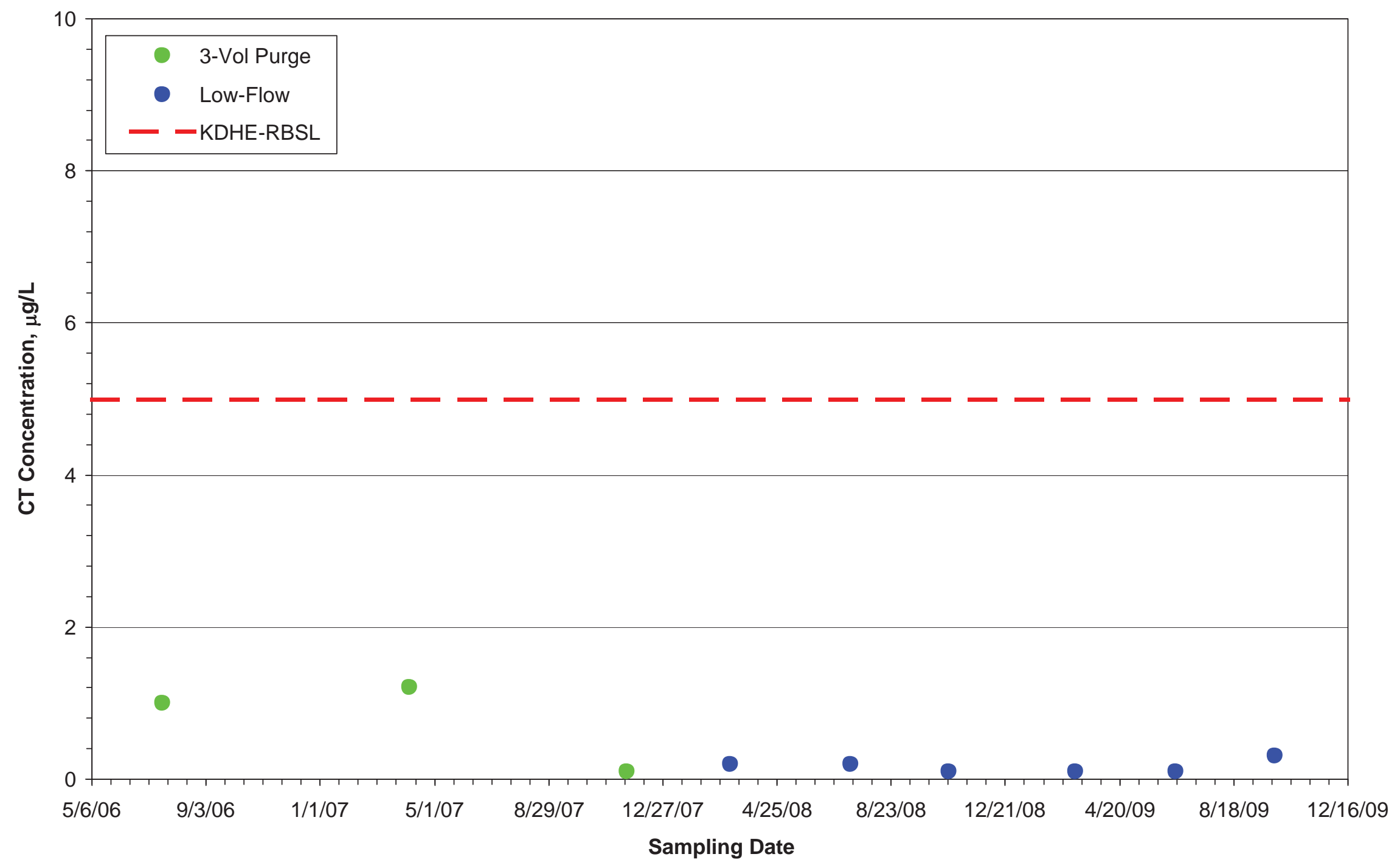

FIGURE E.17 Plot of concentration versus time for deep-zone well MW1D. 
Barnes MW10S

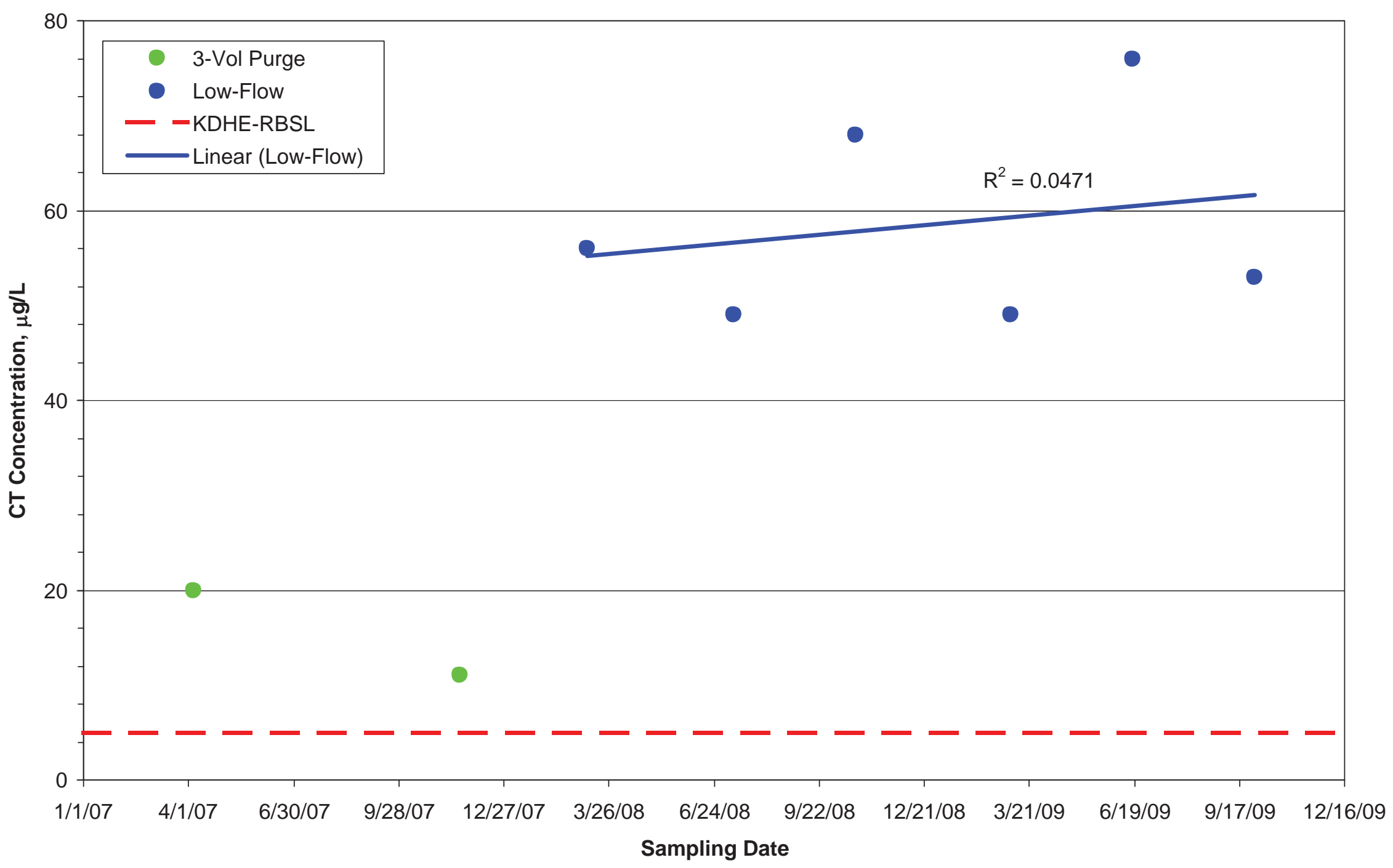

FIGURE E.18 Plot of concentration versus time for intermediate-zone well MW10S. 


\section{Barnes MW12M}

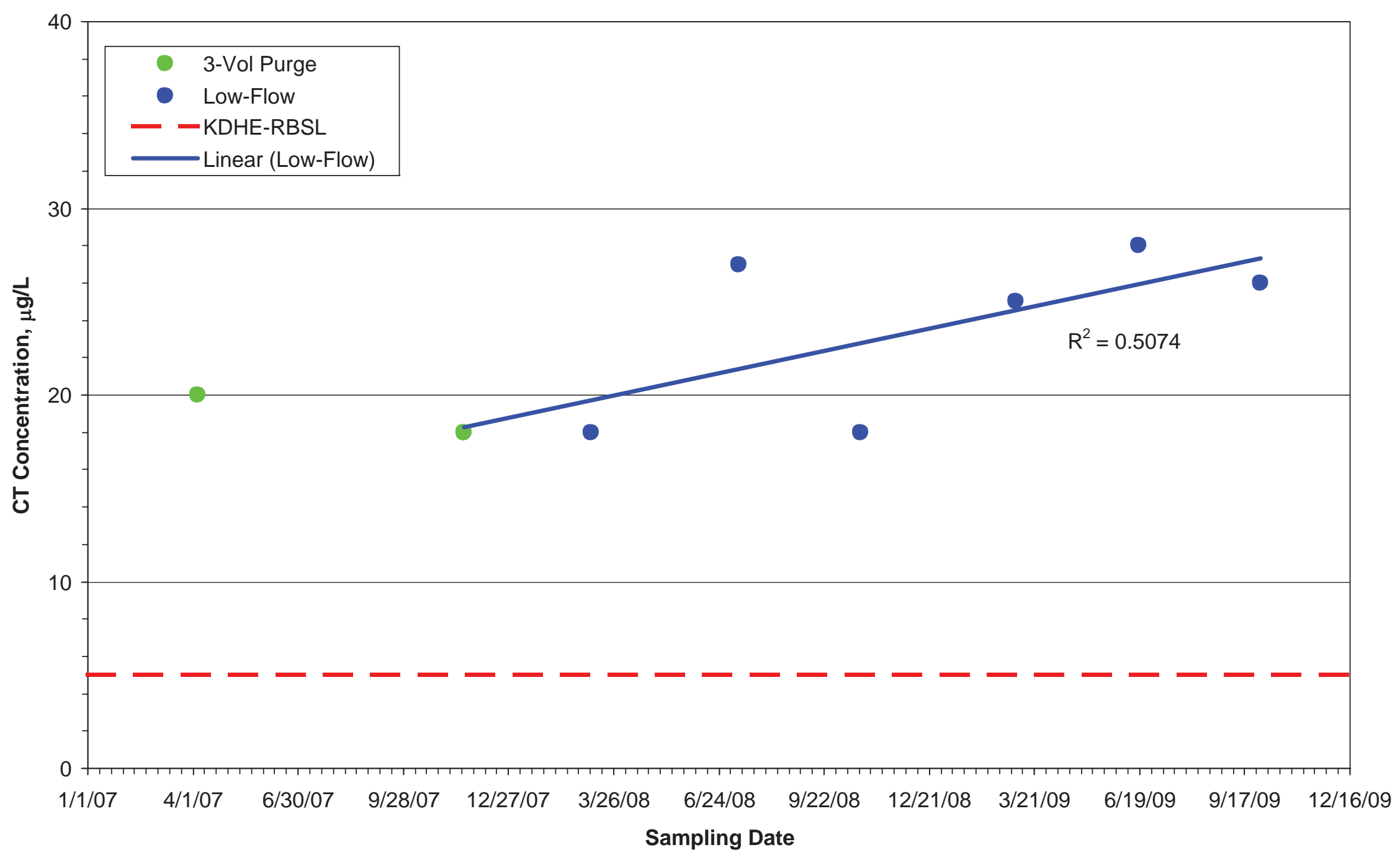

FIGURE E.19 Plot of concentration versus time for intermediate-zone well MW12M. 
Barnes MW11M

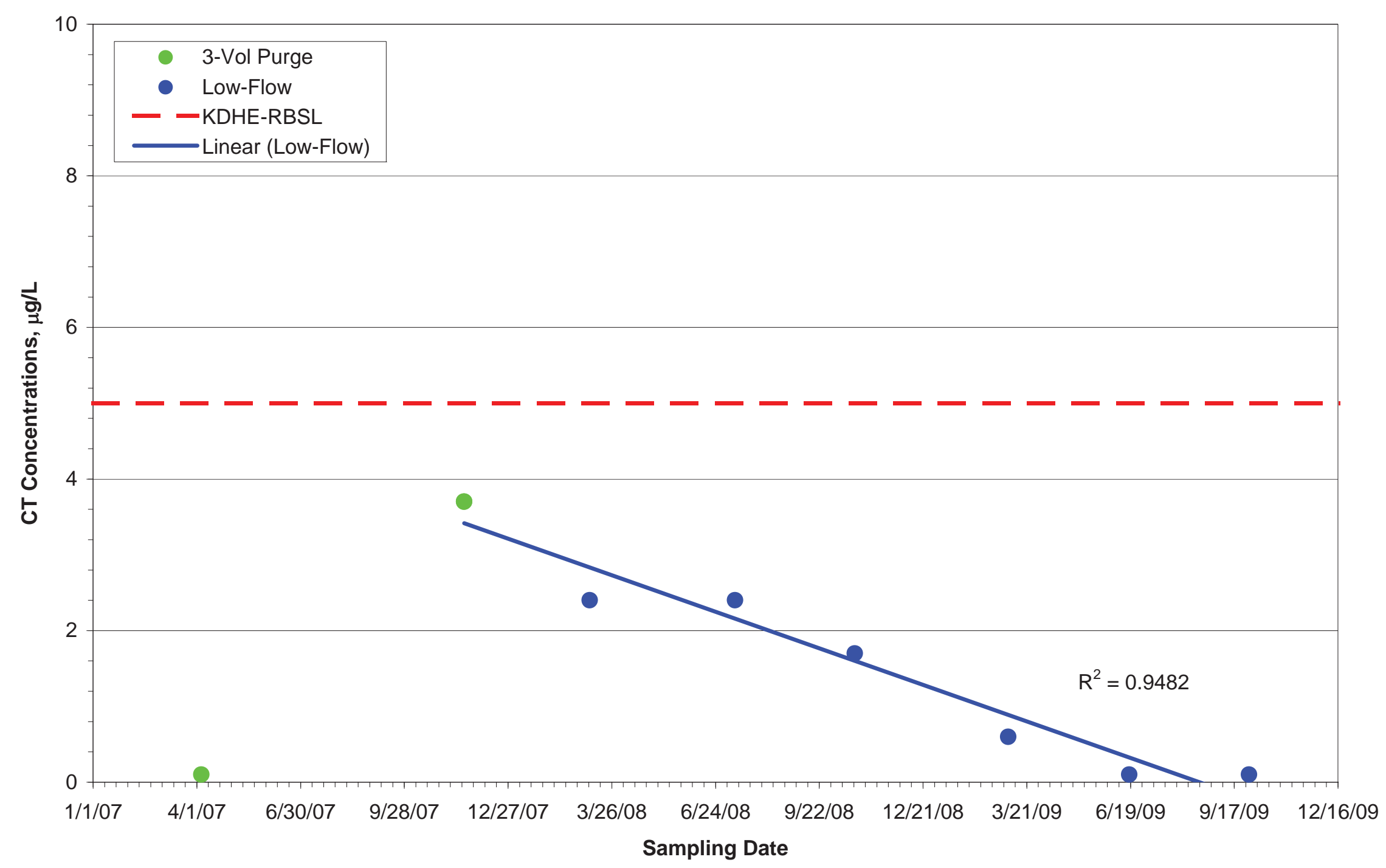

FIGURE E.20 Plot of concentration versus time for intermediate-zone well MW11M. 


\section{Barnes MW13S}

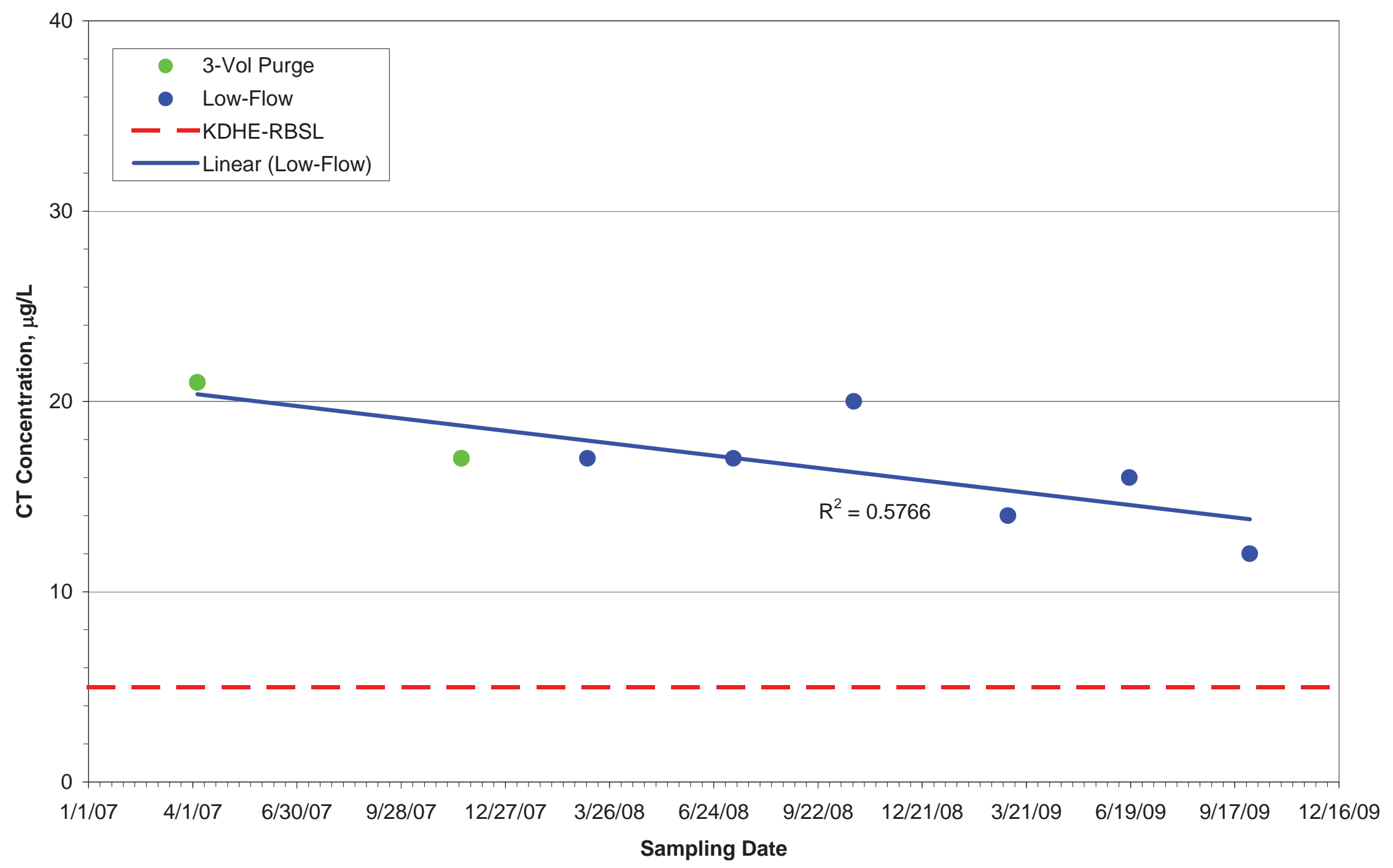

FIGURE E.21 Plot of concentration versus time for intermediate-zone well MW13S. 


\section{Barnes MW17}

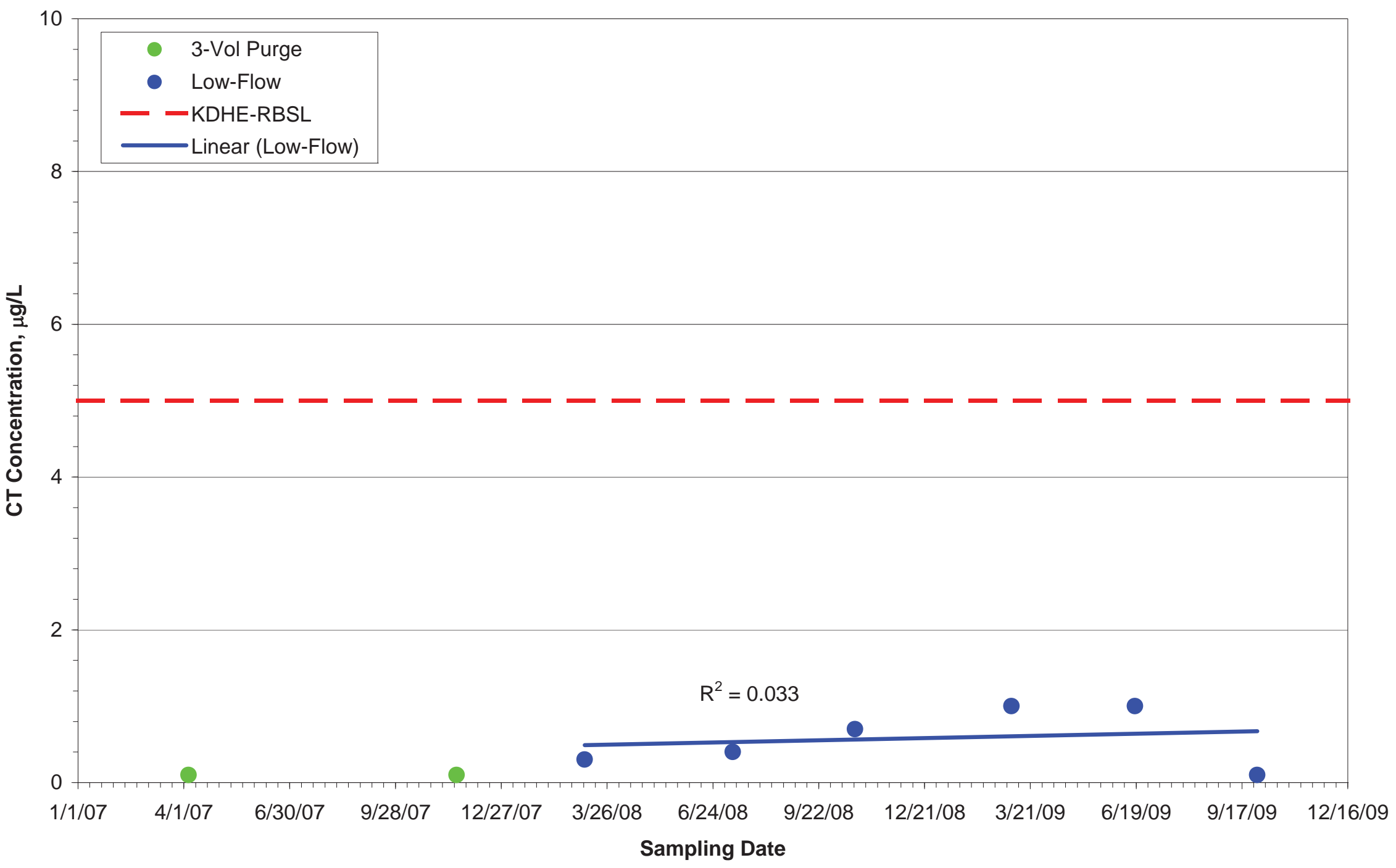

FIGURE E.22 Plot of concentration versus time for intermediate-zone well MW17. 
Barnes Public Well PWS2

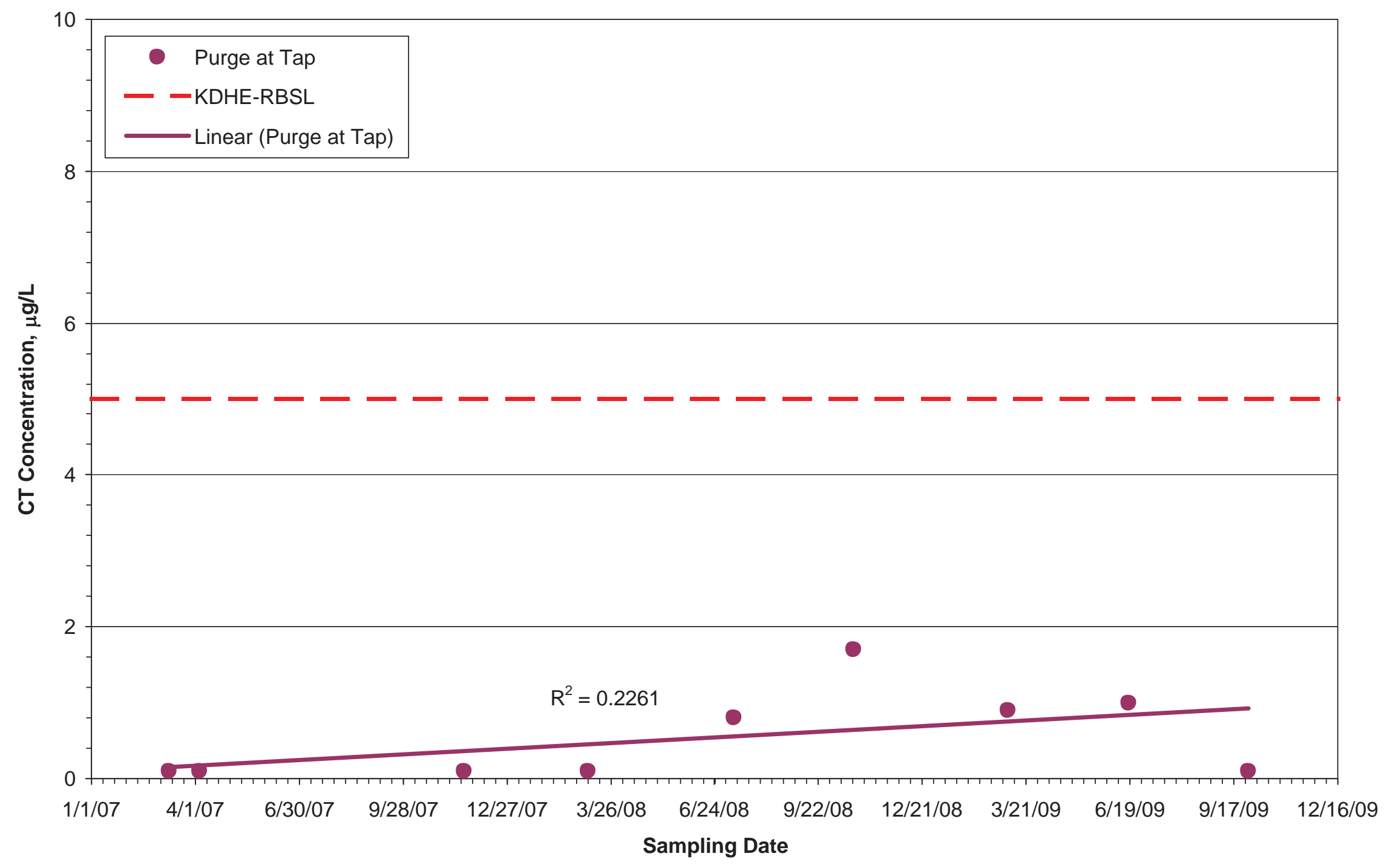


Barnes Public Well PWS3

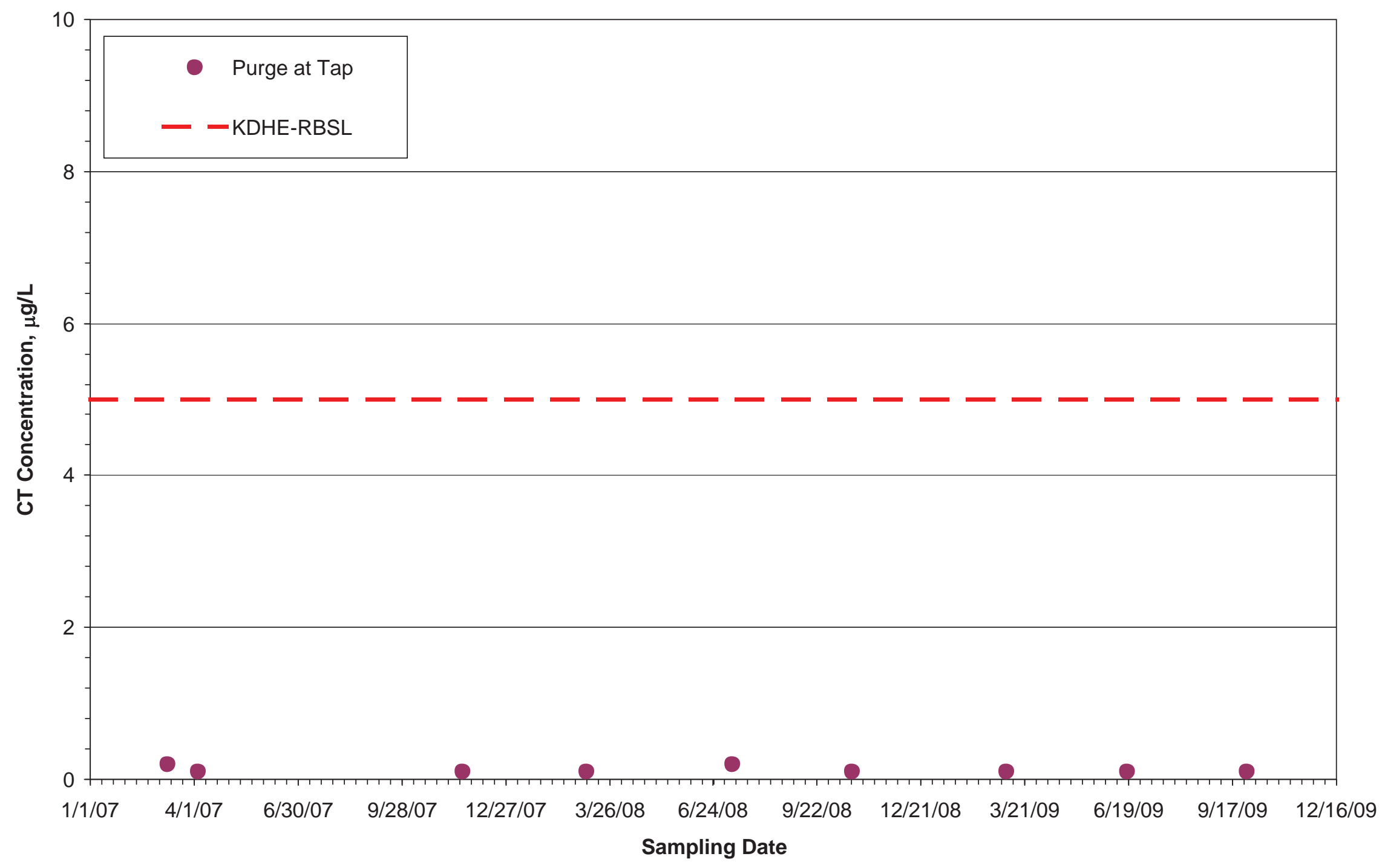

FIGURE E.24 Plot of concentration versus time for well PWS3. 


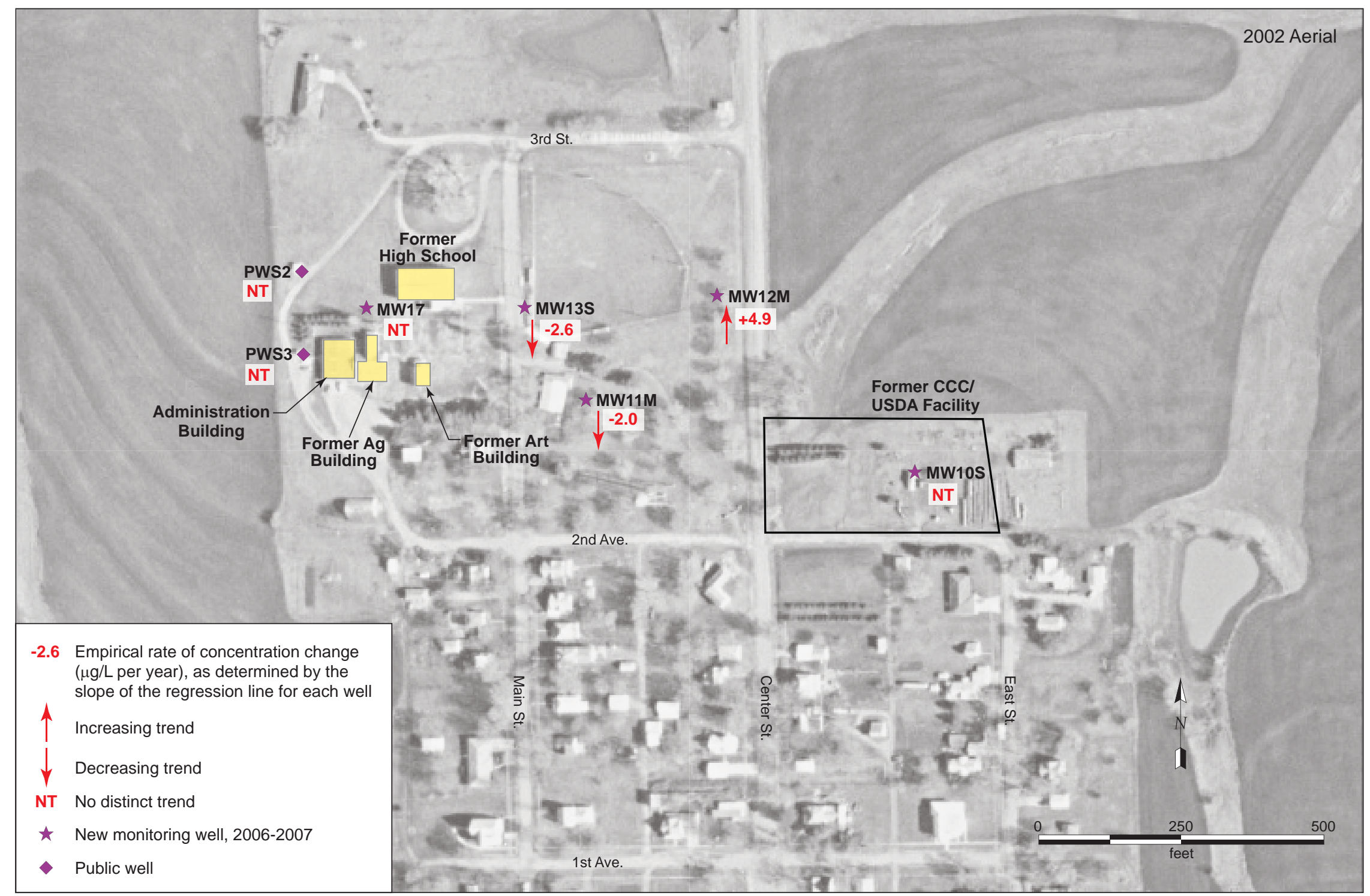

FIGURE E.25 Distribution of apparent carbon tetrachloride trends in the intermediate aquifer zone. 


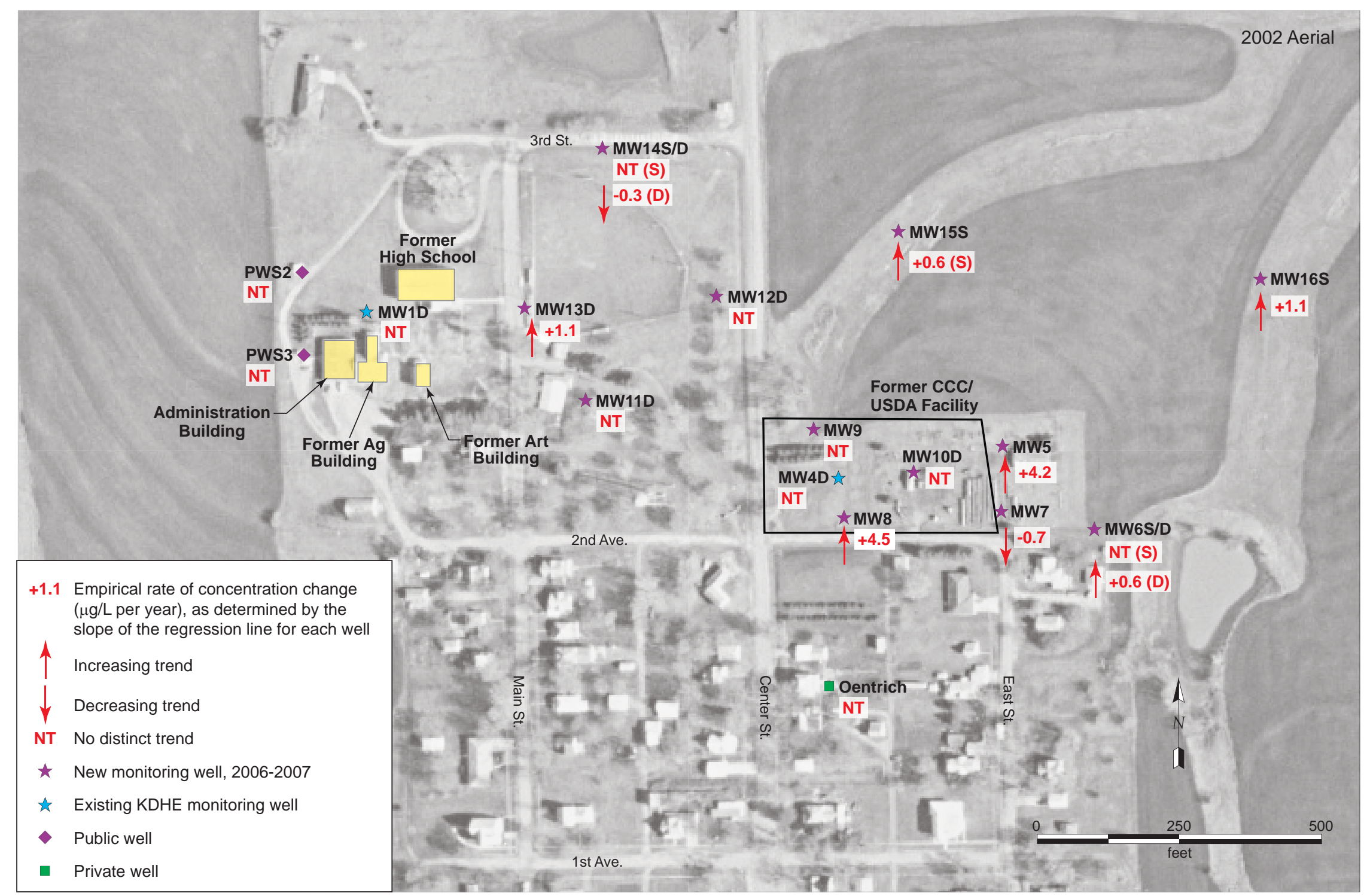

FIGURE E.26 Distribution of apparent carbon tetrachloride trends in the deep aquifer zone. 


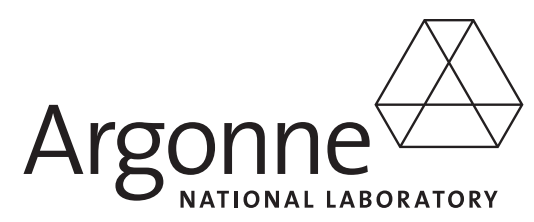

\section{Environmental Science Division}

Argonne National Laboratory

9700 South Cass Avenue, Bldg. 203

Argonne, IL 60439-4843

www.anl.gov 